University of Nebraska - Lincoln

DigitalCommons@University of Nebraska - Lincoln

1957

\title{
Geology and Ground-Water Hydrology of the Valleys of the Republican and Frenchman Rivers Nebraska
}

\author{
Edward Bradley
}

Carlton R. Johnson

Follow this and additional works at: https://digitalcommons.unl.edu/usgspubs

Bradley, Edward and Johnson, Carlton R., "Geology and Ground-Water Hydrology of the Valleys of the Republican and Frenchman Rivers Nebraska" (1957). Publications of the US Geological Survey. 101. https://digitalcommons.unl.edu/usgspubs/101

This Article is brought to you for free and open access by the US Geological Survey at DigitalCommons@University of Nebraska - Lincoln. It has been accepted for inclusion in Publications of the US Geological Survey by an authorized administrator of DigitalCommons@University of Nebraska - Lincoln. 
Geology and Ground-Water Hydrology of the Valleys of the Republican and Frenchman Rivers

\section{Nebraska}

GEOLOGICAL SURVEY WATER-SUPPLY PAPER 1360-H

Prepared as part of the program of the Department of the Interior for development of the Missouri River basin

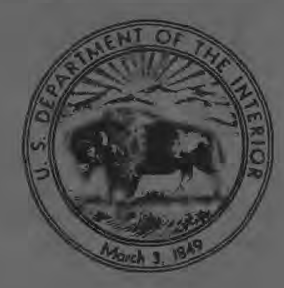





\section{Geology and Ground-Water}

\section{Hydrology of the Valleys}

of the Republican and Frenchman Rivers

\section{Nebraska}

By EDWARD BRADLEY and CARLTON R. JOHNSON

CONTRIBUTIONS TO THE HYDROLOGY OF THE UNITED STATES

GEOLOGICAL SURVEY WATER-SUPPLY PAPER 1360-H

Prepared as part of the program of the Department of the Interior for development of the Missouri River basin

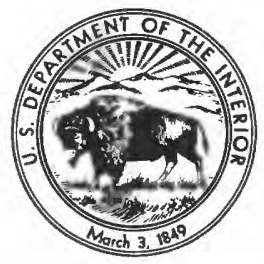




\title{
UNITED STATES DEPARTMENT OF THE INTERIOR
}

\author{
FRED A. SEATON, Secretary
}

\section{GEOLOGICAL SURVEY}

Thomas B. Nolan, Director 


\section{CONTENTS}

Abstract

Introduction

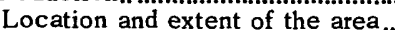

Previous investigations

Present investigation..

Well-numbering system

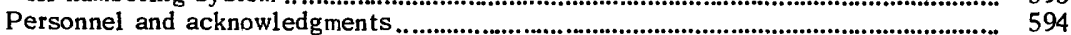

Geography

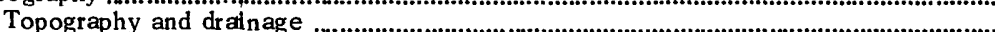

Climate

Economic and cultural features

Geologic formations and their water-bearing properties

Cretaceous system.................................................................................................... 599

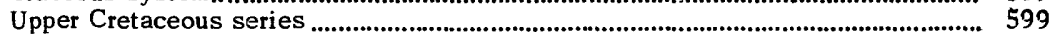

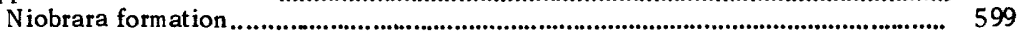

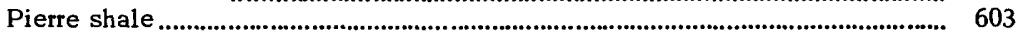

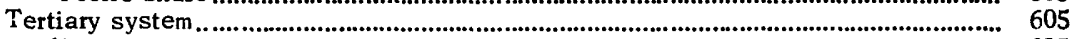

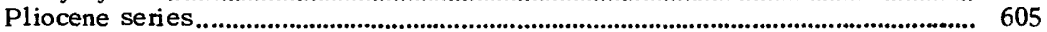

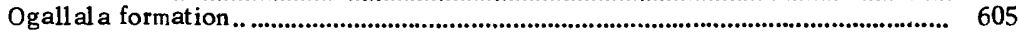

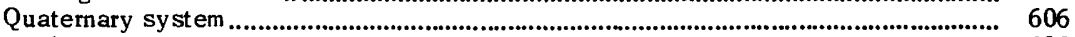

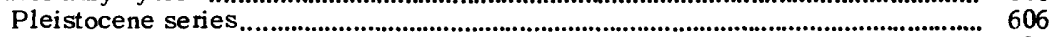

Holdrege and Grand Island formations, undifferentiated ....................................... 606

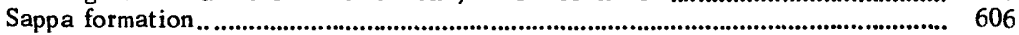

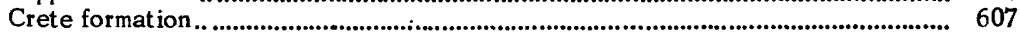

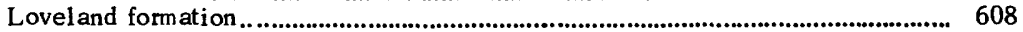

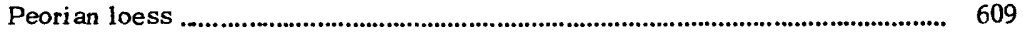

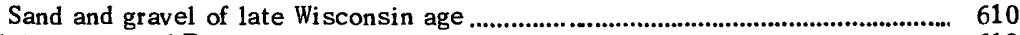

Pleistocene and Recent series ................................................................................. 610

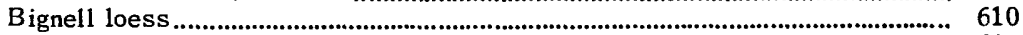

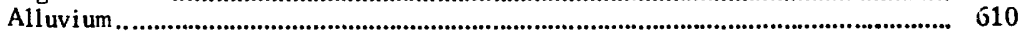

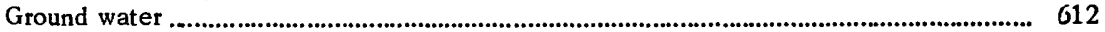

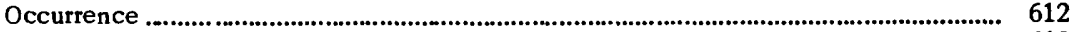

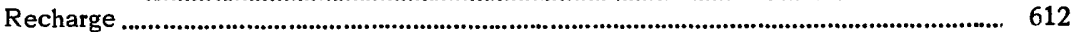

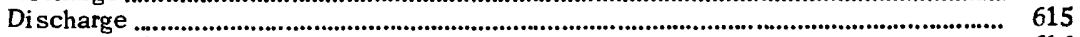

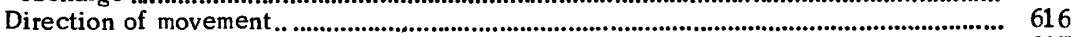

Configuration of the water table ................................................................................... 617

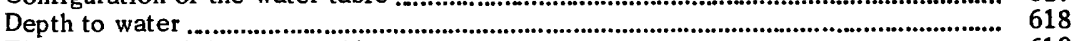

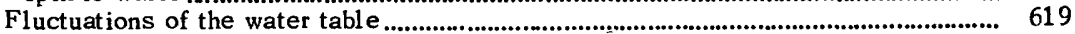

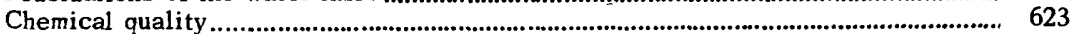

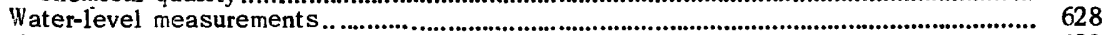

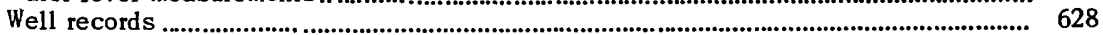

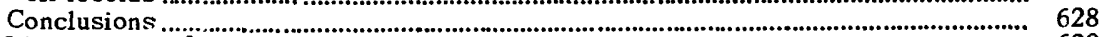

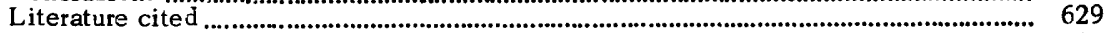

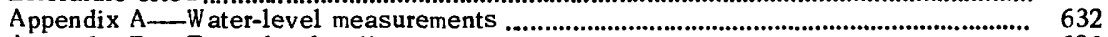

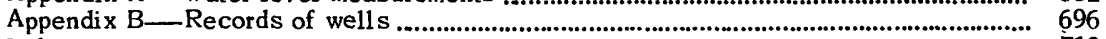

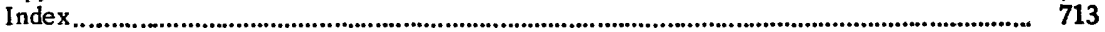




\section{ILLUSTRATIONS}

[All plates in pocket]

Plate 37. Map of part of the valleys of the Republican and Frenchman Rivers, Nebraska, showing the locations of wells and profiles of the water table.

38. Geologic section of the Republican River valley near McCook.

39. Map showing the contour of the water table in the Republican River valley from Orleans to the Colorado State line.

40. Map showing the depth to water in the Republican River valley from Orleans to Stratton.

41. Profiles of the water table in the Republican River valley.

42. Hydrographs of the water level in observation wells, 1934-50.

43. Hydrographs of the water level in observation well s, 1946-50.

Figure 74. Map showing areas in which ground-water studies have been made under the program for development of the Missouri River basin

75. Index map of Nebraska showing area described by this report .........................592

76. Well-numbering system..................................................................................... 594

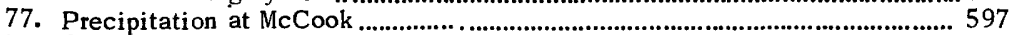

78. Comparison of the volume of streamflow in the Republican and Frenchman Rivers with the water level in wells

79. Comparison of the water surface of Enders Reservoir with the water level in nearby wells

80. Comparison of the water surface of Medicine Creek Reservoir with the water level in nearby wells

81. Classification of irrigation water. 


\title{
GEOLOGY AND GROUND-WATER HYDROLOGY OF THE VALLEYS OF THE REPUBLICAN AND FRENCHMAN RIVERS, NEBRASKA
}

\author{
By Edward Bradley and Carlton R. Johnson
}

\begin{abstract}
The geology and ground-water resources of the upper Republican River valley west of the town of Alma, Nebr., to the Nebraska-Colorado State line and of the Frenchman River valley from its confluence with the Republican River to a point about 12 miles upstream from Wauneta, Nebr., were studied from January 1950 to April 1951. The purpose of the study was to relate the occurrence of ground water to irrigation and flood control and to aid in the evaluation of the effects of irrigation on the land in the area.
\end{abstract}

The area included in this study consists of 370 square miles of flat or gently sloping terraces and bottom land that border the Republican and Frenchman Rivers on either side. The Republican River is a comparatively shallow stream, ranging in width from about 150 feet at the western end of the area to about 300 feet at the eastern end. The channel banks are low, except where the river cuts into bordering terraces. In many places, natural levees of loose sand and gravel have been formed adjacent to the river banks.

The bedrock formations exposed in the area are the Niobrara formation and the Pierre shale of Cretaceous age and the Ogallala formation of Tertiary age. Deposits of sand and gravel, of early Pleistocene age, are present in the bottom of the ancestral Republican River valley and along the north side of the present valley. These coarse deposits are mantled by finer sediments of later PIeistocene and Recent age. Large quantities of ground water are available from the Pleistocene and Recent deposits throughout most of the Republican River valley. In the center of the valley as much as 40 to 60 feet of the deposits are saturated.

The ground-water reservoir is recharged principally by precipitation. Ground water also enters the Republican River valley by underflow through the fill of tributary valleys. Ground water is discharged by evaporation, transpiration, and effluent streams; ground water also is drawn upon extensively for irrigation, for municipal supplies, and for domestic and stock use in rural areas.

In general, ground water in the Republican River valley moves toward the river in a downstream direction. However, the direction of ground-water movement from the uplands into the valley is more transverse to the axis of the valley. The configuration of the water table is affected significantly by the configuration of the underlying bedrock floor, the ratio between recharge and discharge, and the permeability of the aquifer. In general, however, the water table in the valley conforms to the configuration of the land surface.

Depth to water throughout most of the Republican River valley ranges from about 2 feet near the river to about 40 feet adjacent to the bluffs along the edge of the valley. The water table is generally less than 10 feet at the foot of surface of the flood plain and the 
lowest river terrace. In the Frenchman River valley, the depth to water ranges from less than 10 feet to about 60 feet. Seasonal water-level fluctuations are due to variations in the amount and distribution of precipitation, to temperature changes, and to other factors that affect the amounts of ground-water recharge and discharge.

Ground water in the report area is predominantly of the calcium magnesium bicarbonate type. In the extreme westem part of the area, however, calcium and $\mathrm{m}$ agnesium sulfates comprise the major part of the dissolved constituents.

This report includes records of water-level measurements, records of all wells that were measured, geologic sections, and maps showing the location of wells, the depth to water, and the contour of the water table.

\section{INTRODUCTION}

\section{LOCATION AND EXTENT OF THE AREA}

The area described in this report includes the following: The Republican River valley from Alma in south-central Nebraska to the Colorado-Nebraska State line; the valley of the Frenchman River from its confluence with the Republican near Culbertson, Nebr., to a point about 12 miles upstream from Wauneta, Nebr.; the lower valleys of Driftwood and Red Willow Creeks, tributary streams of the Republican River; and the immediate vicinity of Enders and Medicine Creek Reservoirs. The total area of about 370 square miles includes parts of Harlan, Furnas, Frontier, Red Willow, Hitchcock, Hayes, Chase, and Dundy Counties, Nebr. (See figs. 74 and 75 .)

\section{PREVIOUS INVESTIGATIONS}

The first detailed study of the geology and ground-water conditions in the Republican River valley was made by $G$. E. Condra (1907). A report by $H$. A. Waite, E. C. Reed, and D. S. Jones (1946) contains much valuable information on both the geology and ground-water hydrology, and includes the results of a comprehensive program of test drilling in several southern and southwestern counties in Nebraska. The most recent information on the area, however, is a progress report by H. A. Waite and others (1948), with a section on the chemical quality of the ground water by $H$. A. Swenson. Reference is also made in the text to additional published and unpublished reports pertaining to the geology or water resources of the Republican River valley.

From 1934 to 1946 , water-level measurements in the Republican River valley were made at relatively,infrequent intervals and from widely scattered wells. In 1946, the U. S. Geological Survey installed 44 water-level observation wells and inventoried a number of private wells. In 1948 and 1949, the U. S. Bureau of Reclamation installed 137 observation wells along the Cambridge Canal and in the vicinity of Trenton and Enders Reservoirs. 


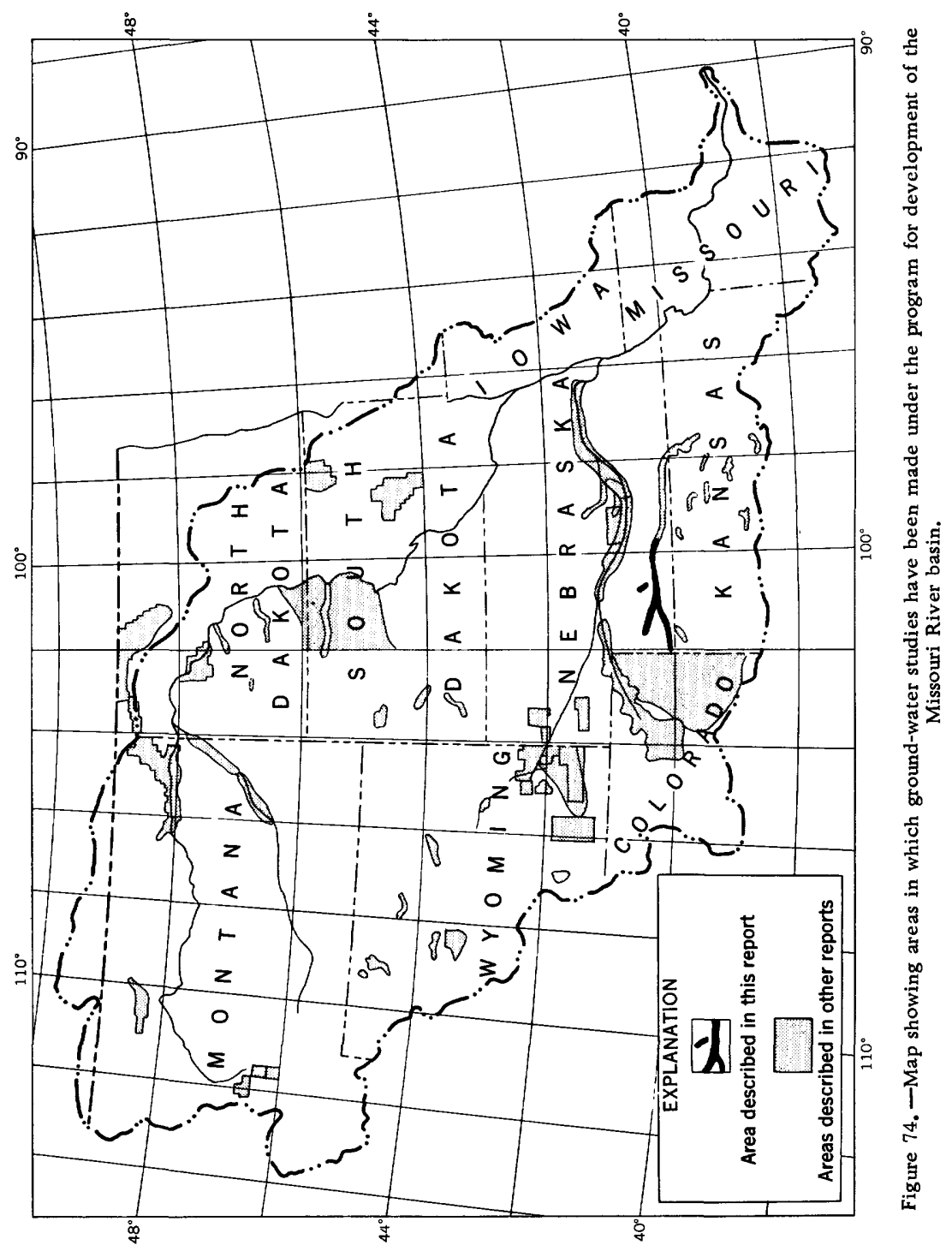




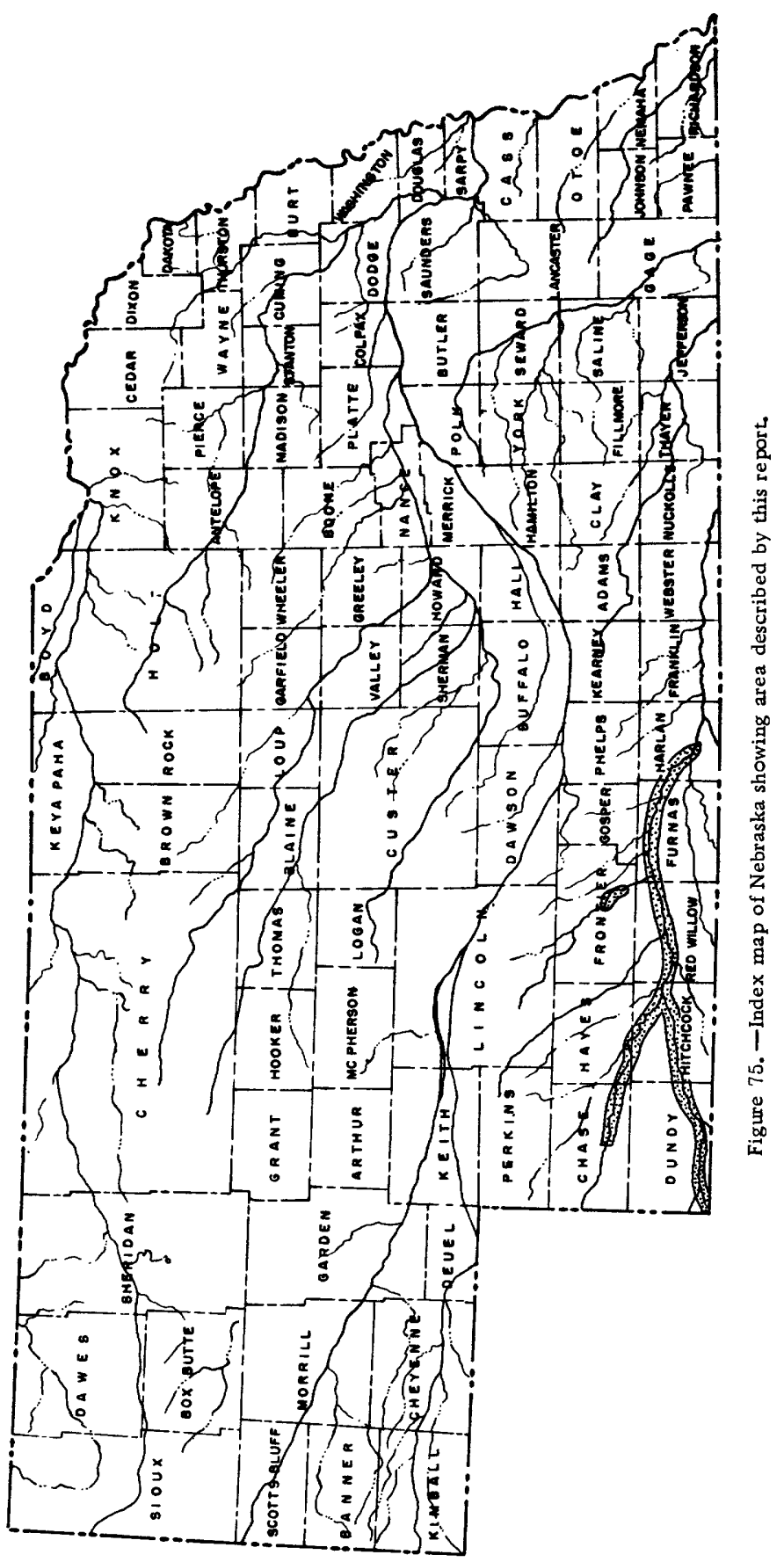


In 1936 the U. S. Geological Survey made chemical analyses of water from 6 wells in the area, and in 1947 of an additional 16 wells. The results of these analyses are included in this report, and the location of the sampled wells is shown on plate 37 .

\section{PRESENT INVESTIGATION}

The principal objectives of this investigation are to present new information and to expand, to the extent of available data, previous discussions of the geology and ground-water conditions in the area.

At the beginning of this investigation 173 wells were selected for use as observation wells in addition to those alreadybeing used for that purpose, and by the end of 1950 periodic water-level measurements were being made in 456 wells in the area. Of this total, 67 were privately owned irrigation wells and 37 were privately owned domestic or stock wells, many of which are now unused. The location of these wells is shown in plate 37 . The measurements of the water level in these wells provide in large part the basis for this discussion of ground-water conditions. The discussion of the geology is based on a reconnaissance of the principal outcrops in the area and on the reports by previous investigators.

This investigation was made as a part of a program of the Department of the Interior for development of the Missouri River basin. Begun in January 1950, it was terminated abruptly in April 1951 because more urgent studies elsewhere in the Missouri River basin required the services of the personnel engaged in this investigation. Therefore, the study was not completed and the report is not as comprehensive as originally planned.

\section{WELL-NUMBERING SYSTEM}

The well-numbering system used in this report is based upon the location of the well within the land subdivision of the Bureau of Land Management's survey of the area. (See fig. 76.) The first numeral of a well number denotes the township, the second the range, and the third the section. The lowercase letters that follow the section number indicate the position of the well within the section; the first letter indicates the quarter section, the second the quarter-quarter section, and the third, if present, the quarterquarter-quarter section, or 10-acre tract. The letters $a, b, c$, and $d$, are assigned in a counterclockwise direction, beginning in the northeast quadrant of the section, or quarter-quarter section. If two or more wells are located within the same 10 -acre tract, they are distinguished by numerals following the lowercase letters. 


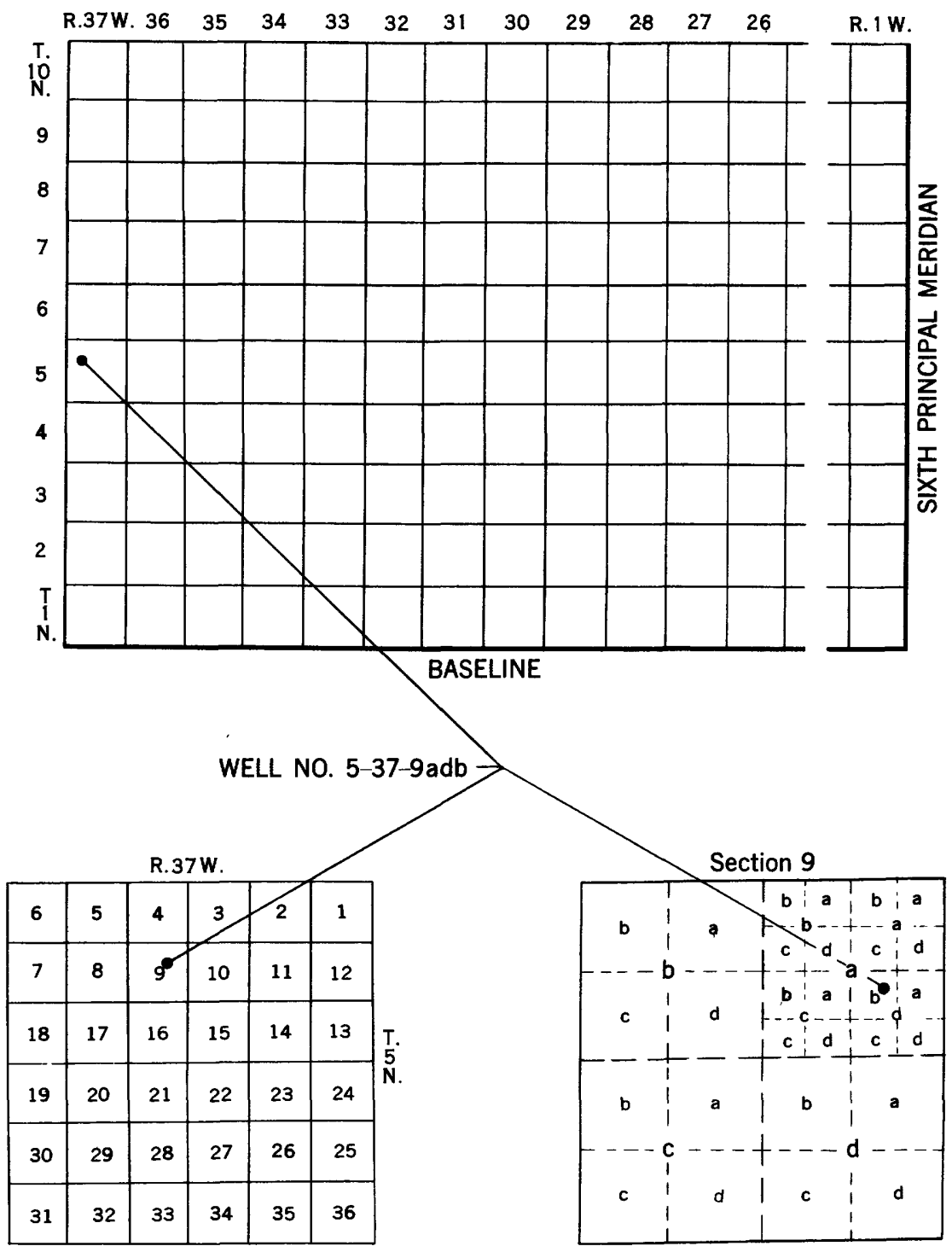

Figure 76. -Well-numbering system.

\section{PERSONNEL AND ACKNOWLEDGMENTS}

This investigation was made under the general supervision of A. N. Sayre, chief of the Ground Water Branch of the U. S. Geo- 
logical Survey, and G. H. Taylor, regional engineer in charge of ground-water studies in the Missouri River basin. H. A. Waite, district geologist in charge of ground-water studies in Nebraska, directly supervised the field studies and the preparation of this report, and personnel of the Quality of Water Branch, Lincoln, Nebr., reviewed that part of the report relating to the chemical quality of the water. The late F. G. Schnittker assisted in the initial fieldwork.

E. C. Reed of the Nebraska State Geological Survey gave helpful suggestions and supplied information concerning the geology and physiography of the region. C. S. Osborn, C. T. Jamison, and others of the Kansas River District of the U. S. Bureau of Reclamation assisted in the fieldwork and also reviewed the manuscript. G. L. Whitaker of the Geological Survey supplied valuable data pertaining to surface-water conditions in the area.

Farmers and landowners throughout the valleys of the Republican and Frenchman Rivers permitted the installation of observation wells on their properties and the taking of periodic water-level measurements in these and their own private wells.

\section{GEOGRAPHY}

\section{TOPOGRAPHY AND DRAINAGE}

The western two-thirds of the area described in this report is in the High Plains section of the Great Plains physiographic province; the eastern one-third is in the Plains Border section (Fenneman, 1931). The principal streams are the Republican River and its major tributaries-the Frenchman River and the Medicine, Red Willow, and Driftwood Creeks. The interstream upland areas are comparatively flat loess plains underlain by limy sand and silt of Tertiary age. The Republican River has cut a consequent valley through the rocks of Tertiary age and into the Cretaceous formations. The tributaries likewise occupy consequent valleys, some of which have been cut into Tertiary deposits and others into the Cretaceous formations.

The valley walls are steep and are incised by many narrow tributary canyons that extend into the uplands for distances ranging from several hundred yards to several miles. Many of these tributary canyons grade into flat-bottomed draws in their upper reaches. 
The Republican River flows successively in an easterly, northeasterly, and southeasterly direction in the area discussed in this report. Its gradient ranges from about 4 to 10 feet per mile. The channel width varies considerably, gradually widening downstream. In Dundy County the stream bed is generally 150 to 250 feet wide, whereas in Furnas and Harlan Counties its width in places exceeds 300 feet. Normally, the channel lies within a flood plain, which generally is less than half a mile wide. Except for the few isolated stretches where the river abuts the valley walls, its flood plain is bordered by one to three terraces, which range from about 5 to 20 feet in height and that slope gently from the valley walls toward the river. The terraces bordering the principal tributaries of the Republican River are usually better formed and more easily recognized than those along the main stream.

The flood plain of the Republican River is a slightly irregular surface that consists of abandoned meander scars, oxbow lakes, lagoons, natural levees, and sand dunes. The natural levees are present only along certain stretches of the river; they are broad irregular masses of loose sand and gravel upon which willow and cottonwood trees flourish. Oxbow and other depressional ponds occur along most of the river's course except where the valley is narrow or the river has incised into the terraces.

\section{CLIMATE}

The climate of southwestern Nebraska is typical of the Great Plains. Variability of temperature and precipitation, which causes irregular but fairly persistent recurrences of drought, is the most significant factor in the climate of the region.

Annual precipitation records for a 63-year period at McCook are shown in figure 77. A comparison of the average annual precipitation and temperature for several towns in the area, including McCook, is shown below.

Average annual precipitation and temperature at Alma, Benkelman, Imperial, and McCook, Nébr.

\begin{tabular}{|c|c|c|c|c|}
\hline Town & $\begin{array}{l}\text { Precipi- } \\
\text { tation, } \\
\text { in } \\
\text { inches }\end{array}$ & $\begin{array}{l}\text { Years } \\
\text { of } \\
\text { record }\end{array}$ & $\begin{array}{c}\text { Temper- } \\
\text { ature, } \\
\text { in } \\
\text { degrees } \\
\text { Fahrenheit }\end{array}$ & $\begin{array}{l}\text { Years } \\
\text { of } \\
\text { record }\end{array}$ \\
\hline 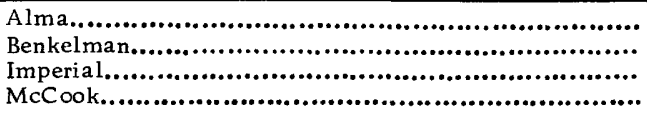 & $\begin{array}{l}21.7 \\
18.32 \\
20.73 \\
19.85\end{array}$ & $\begin{array}{l}53 \\
45 \\
58 \\
63\end{array}$ & $\begin{array}{l}52.4 \\
52.3 \\
50.3 \\
52.1\end{array}$ & $\begin{array}{l}48 \\
30 \\
57 \\
48\end{array}$ \\
\hline
\end{tabular}


GROUND-WATER GEOLOGY, REPUBLICAN AND FRENCHMAN VALLEYS, NEBR. 597

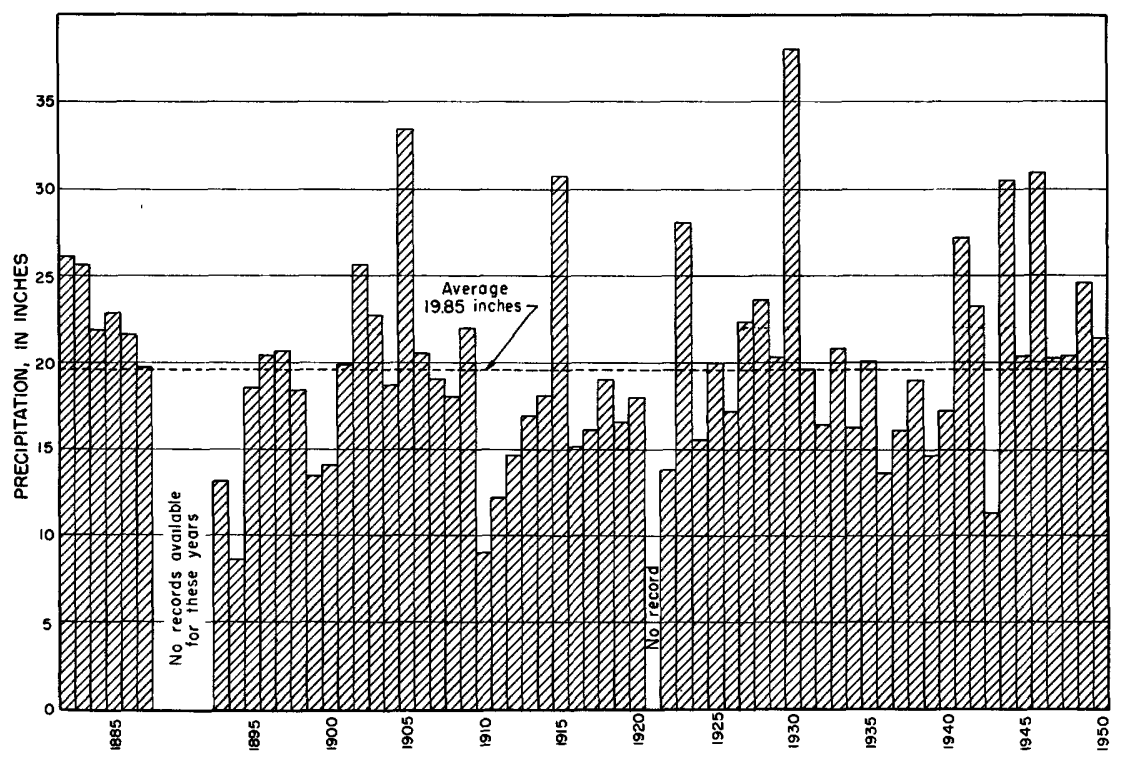

Figure 77. - Precipitation at McCook, 1882-1950. (From records of the U. S. Weather Bureau)

The total annual precipitation ranges widely from year to year, and monthly totals also differ considerably. In general, the greatest precipitation occurs in May, June, and July and the least occurs in the winter months. In addition to the variability of the precipitation in both the monthly sequence and the annual totals, a wide range is also characteristic of the areal distribution. Much of the late spring and early summer rainfall occurs as heavy local showers.

The average annual temperature at McCook, based on a 48-year record, is $52.1^{\circ} \mathrm{F}$. Low temperatures in the area range from $-10^{\circ}$ to $-20^{\circ} \mathrm{F}$ and high temperatures from $100^{\circ}$ to $110^{\circ} \mathrm{F}$. During the summer months protracted periods of hightemperature accompanied by strong wind sometimes result in drought or neardrought conditions. The last killing frost in the spring usually occurs in early May, and the first killing frost usually occurs in early October. The afternoon wind velocity averages 14 to 16 miles per hour.

Ground-water recharge is directly affected by moisture conditions in the soil which in turn are dependent upon evaporation and runoff. The dependability of the ground-water supply, therefore, hinges ultimately on climatic factors. Normally, variations in atmospheric pressure produce subsequent changes in groundwater levels in the Republican River valley. 
Average monthly.precipitation and temperature at $\mathrm{McCook}, \mathrm{Nebr}$.

\begin{tabular}{|c|c|c|}
\hline Month & $\begin{array}{c}\text { Precipitation, } \\
\text { in inches }\end{array}$ & $\begin{array}{c}\text { Temper- } \\
\text { ature, in } \\
\text { degrees } \\
\text { Fahrenheit }\end{array}$ \\
\hline February & \begin{tabular}{r|}
0.41 \\
.66 \\
.96 \\
2.09 \\
2.89 \\
3.31 \\
2.88 \\
2.50 \\
1.77 \\
1.12 \\
.66 \\
.60
\end{tabular} & $\begin{array}{l}27.5 \\
31.4 \\
40.1 \\
51.3 \\
61.2 \\
71.1 \\
77.9 \\
75.9 \\
66.5 \\
54.2 \\
39.4 \\
29.3\end{array}$ \\
\hline
\end{tabular}

\section{ECONOMIC AND CUL TURAL FEATURES}

The economy of the Republican River valley depends almost entirely upon agriculture. According to recentestimates by the U. S. Department of Agriculture and the Nebraska Department of Agriculture and Inspection, the income derived from beef cattle in the several counties included in this report is more than twice that derived from wheat, which is the next most important product. Corn, dairy products, and hogs, in that order, are the other leading agricultural products, and oats, barley, rye, sorghum, alfalfa, and potatoes also are common crops. However, as the order of importance of the crops is based on the entire area of each county, it does not necessarily apply also to the valley land. Corn and other irrigated crops are grown much more extensively in the river valleys.

The use of ground water in the agricultural economy has become increasingly important in recent years. In the early development of the area, water used for irrigation was obtained by diverting streamflow. Several large canals were constructed in the 1890's, and their completion probably was hastened by the severe drought in 1894-95. The drilling of a large number of irrigation wells during the dry years of the 1930 's also resulted in an increase in the irrigated acreage. Although irrigation by pumping from wells is restricted largely to the valleys, wells for domestic purposes and stock watering have been drilhed or dug on the uplands since early settlement of the area.

The principal municipalities in the region are situated in the stream valleys. (See pl. 37.) McCook, the largest town in the area, is about midway between Denver and Omaha and is an important railroad division point for the Chicago, Burlington \& Quincy Railroad. 
Most of the towns along the Republican River obtain adequate water supplies from wells in the alluvial fill of the valley.

\section{GEOLOGIC FORMATIONS AND THEIR WATER-BEARING PROPERTIES}

Bedrock crops out in valley walls along the Republican River except on the north side of the river from the mouth of the Frenchman River to the eastern limit of the area coveredby this investigation. In most places, however, the bedrock is mantled by unconsolidated materials of Pleistocene and Recent age. The bedrock formations that crop out in the area are the Niobrara formation and the Pierre shale of Late Cretaceous age and the Ogallala formation of Tertiary age.

The generalized section of geologic formations (p. 600-6u1) lists their thicknesses, lithologic character, and importance as a source of water supply. The stratigraphic terminology used is that of the Nebraska Geological Survey (Condra and Reed, 1943, and Condra, Reed, and Gordon, 1950).

\section{CRETACEOUS SYSTEM}

\section{UPPER CRETACEOUS SERIES}

\section{NIOBRARA FORMATION}

The Niobrara formation crops out above the Republican River and its tributaries near Cambridge, where the valley crosses the axis of the Cambridge Arch (Condra and Reed, 1943). Generally, the Niobrara formation is mantled by deposits of Quaternary age. At Edison the outcrop is relatively narrow, and the Pierre shale occupies a part of the bottom land on either side of the Republican River. Near Indianola, the Niobrara formation passes beneath the Pierre shale. Along the Republican River south of Orleans, the alluvial deposits have been partly removed, and the chalk rock of the Niobrara formation is exposed in the banks of the river. The formation also crops out in the valley walls and floor of Medicine Creek, which is tributary to the Republican River. Medicine Creek flows in a southerly to southeasterly direction, roughly parallel to the axis of the Cambridge Arch (Condra and Reed, 1943), and its valley is cut into the Niobrara formation from the mouth of the creek upstream for about 40 miles. The exposures most suitable for study were found in the talus-littered slopes and cliffs along Medicine Creek and its tributary draws and canyons. 


\begin{tabular}{|c|c|c|c|c|c|c|c|c|}
\hline 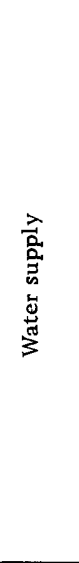 & 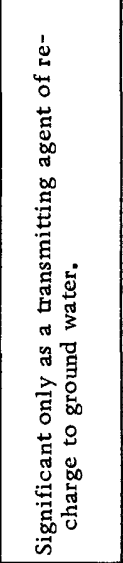 & $\dot{8}$ & 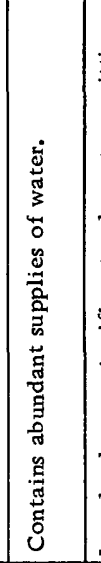 & 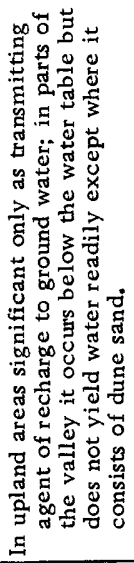 & 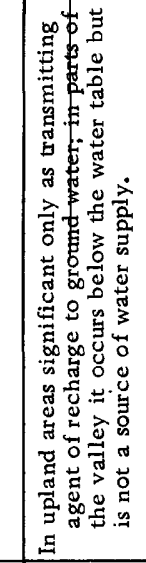 & 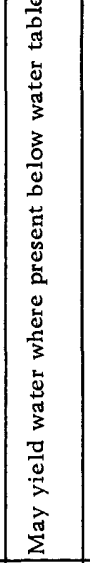 & 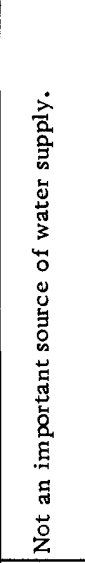 & 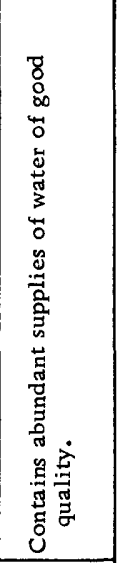 \\
\hline 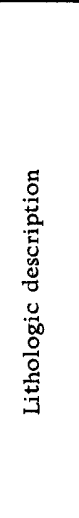 & 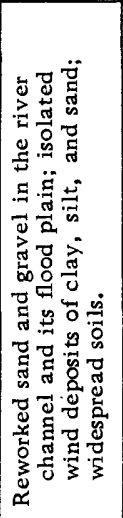 & 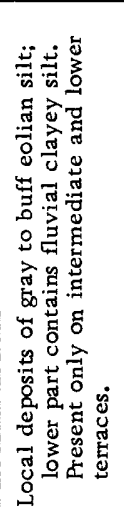 & 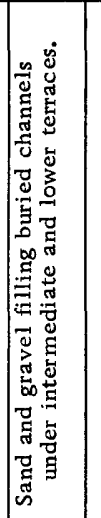 & 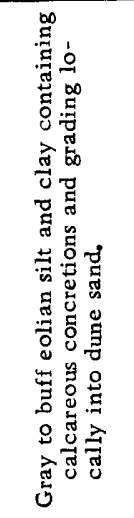 & 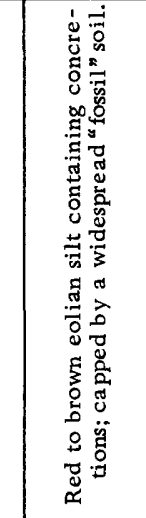 & 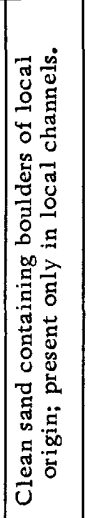 & 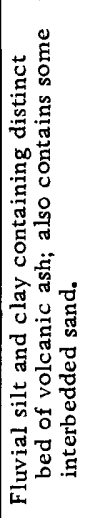 & 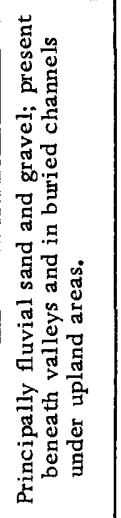 \\
\hline 总 & ণ্ & 市 & $\begin{array}{l}0 \\
1 \\
0\end{array}$ & $\begin{array}{l}\vdots \\
\vdots\end{array}$ & $\begin{array}{l}0 \\
1 \\
0\end{array}$ & $\stackrel{\text { }}{i}$ & 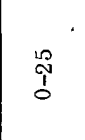 & $\begin{array}{l}0 \\
0 \\
1 \\
0\end{array}$ \\
\hline 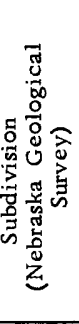 & 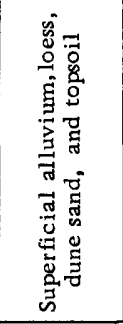 & 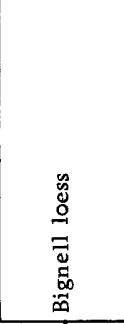 & 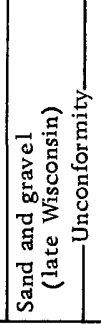 & 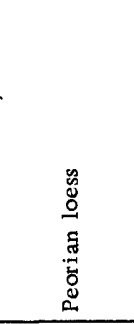 & 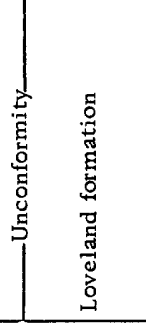 & 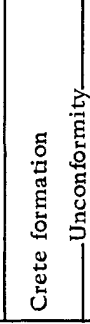 & 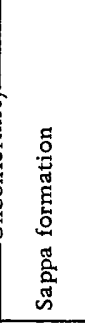 & 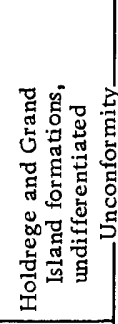 \\
\hline 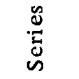 & \multicolumn{2}{|c|}{ ұиәวәу } & \multicolumn{6}{|c|}{ 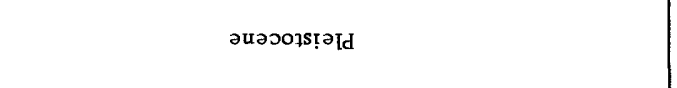 } \\
\hline 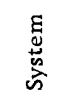 & & & & & & & & \\
\hline
\end{tabular}


GROUND-WATER GEOLOGY, REPUBLICAN AND FRENCHMAN VALLEYS, NEBR. 601

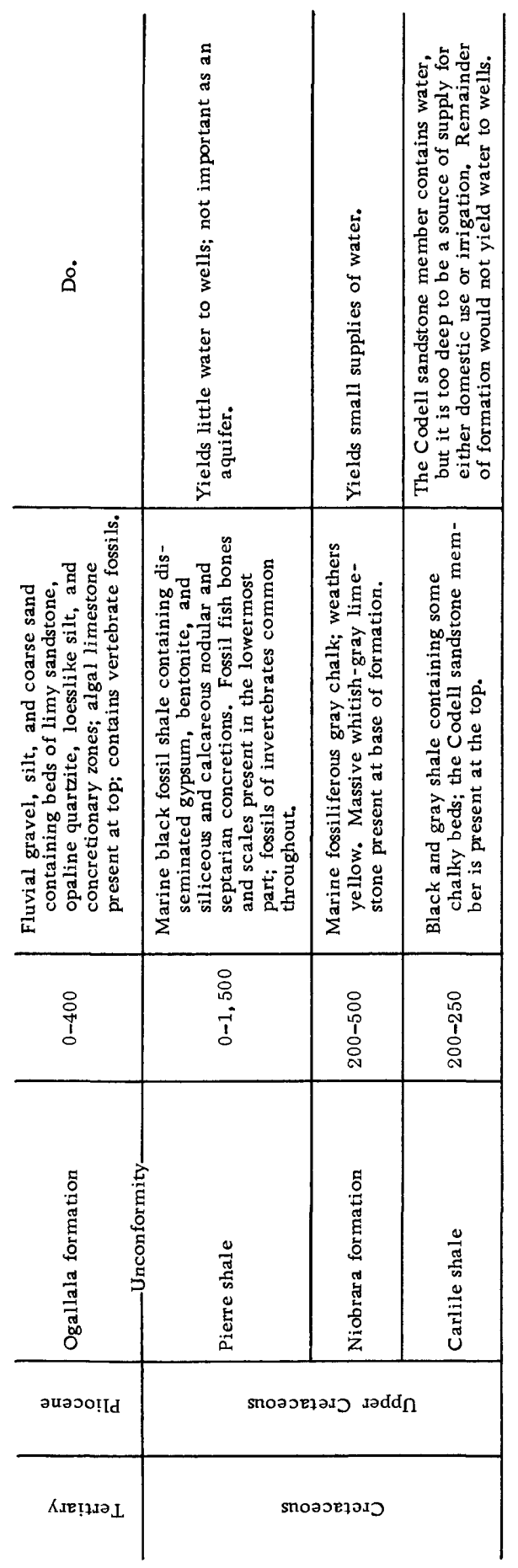

$4245900-57-2$ 
The prevailing colors of the Niobrara formation are lead gray, light gray, and yellowish gray, depending in part on the degree of weathering. Much of the weathered rock is yellow to cream, and in certain localities it is ocherous. The rock in the exposures along Medicine Creek ranges from yellow in the upper weathered part to lead gray with a bluish tint in the lower unweathered part. In places the yellow chalk is somewhat flinty. Beds of flint with a brownish, reddish, or greenish tint are present in the upper part of the formation; in the lower part of the formation the flint is present as scattered nodules. Some of the upper beds are stained bright red. The chalk weathers initially into broad thick slabs and further disintegrates into small conchoidal fragments. The orientation of the slabs is parallel to the color banding, a fact that supports the conclusion that the color bands indicate the attitude of the bedding planes. The rock consists of soft chalky limestone and limy clay. In most exposures, the chalk is fine grained, very porous, and, to a large extent, calcareous. Blocks of the chalk are light in weight and generally are rough to the touch. Areas of dense cementation follow the bedding planes, joints and cracks. Silica, the cementing agent, has filled the pores of the rock, making it darker and more dense and vitreous. It is believed that silica accumulated in the chalk subsequent to its deposition, probably during late Tertiary or Quaternary time, and that the additional cement was derived from overlying formations and was transmitted and deposited along joints and cracks by ground water. The joints and cracks are narrow, generally not more than a quarter of an inch wide. Weathered fragments of the vitreous rock show a porous coating, as much as a half an inch thick, surrounding the more dense interior; this indicates that much of the rough, porous exterior of the exposed rock formation has been formed by weathering. The formation is abundantly fossiliferous.

The Niobrara formation has been divided into two lithologically distinct members. The upper, Smoky Hill chalk member, consists of soft chalk interbedded with chalky shale; the lower, Fort Hays limestone member, consists of massive soft chalky limestone. Only the upper and middle parts of the Smoky Hill member are exposed in the area described in this report. The Niobrara formation overlies the Carlile shale, which is present at varying depths. It is overlain in most of the area by the Pierre shale. In the Medicine Creek area, however, the Pierre shale has been removed by pre-Ogallala erosion and the Niobrara formation is overlain by the Ogallala formation of Tertiary age. The thickness of the Niobrara formation in this area ranges from about 200 to 500 feet.

Although the Niobrara formation is quite porous and some what permeable, it is not a good aquifer. Where the Niobrara is over- 
lain by the Ogallala formation, channels that were eroded into the pre-Ogallala surface and that subsequently were filled by sand and grit of the Ogallala formation drain off any water that $m$ ight accumulate near the top of the Niobrara formation. There are no known arenaceous beds in the Niobraraformation that could supply a large yield of ground water to wells. However, water for domestic use on some farms in the Medicine Creek area is obtained from this formation.

\section{PIERRE SHALE}

Except in the vicinity of Cambridge, where it has been removed by erosion, the Pierre shale underlies the Republican River valley throughout the area studied in this investigation. It rests conformably on the Niobrara formation and is overlain unconformably by deposits of Tertiary age. It is exposed along the Republican River and its tributaries from the eastern edge of the area to the vicinity of Arapahoe, and from Indianola to the west boundary of the State. Because the river has cut its valley into this formation, the Pierre shale is exposed in many places along the valley walls and is present at different depths beneath the alluvium of the Republican River valley. The Pierre shale also underlies many of the tributary valleys, especially in their lowermost stretches.

The Pierre shale, where exposed along the Republican River valley in this area, consists mainly of plastic fissile carbonaceous clayey shale. The exposures of Pierre shale are relatively uniform in color-the unweathered rock generally is dark bluish gray to black, and rust-colored spots are common. In Dundy County, however, the upper part of the exposed Pierre shale is yellowish gray. Because only small thicknesses of the formation are exposed in any one locality, it is difficult to identify key beds for the purpose of correlation. Much work has been done in Kansas on the correlation of exposures by using the concretionary zones within the Pierre shale and by using paleontological evidence as a check (Elias, 1931, p. 55-56). Further detailedstratigraphic studies probably will depend upon the use of similar zoning methods. The Pierre shale, wherever exposed along the valley walls, generally is highly weathered, and only the fossils and concretions have retained their identity.

Gypsum crystals are distributed throughout the shale and weather out in great abundance on the barren slopes. Iron pyrite is present in thin layers at many horizons. The pyrite decomposes readily, and the resulting fragments of iron oxide are scattered over the surface. Streaks of limonite and selenite are common 
throughout the shale, and the vertical joints that can be distinguished are marked by veins of selenite crystals. Crusts of selenite and limonite can be broken out easily along the bedding planes. Both hard and soft calcareous concretions are quite common. Fish scales are present in some of the better preserved exposures. The Pierre shale, where exposed, crumbles readily to clayey slopes, and the growth of vegetation upon such slopes almost obscures the exposures. The valleys that have been incised into the Pierre shale are shallow, and the valley sides are gentle rolling slopes.

On the basis of fossil evidence and concretionary zones, the Pierre shale in Kansas has been divided by Elias (1931) into four members. The lowermost member, the Sharon Springs, has been definitely recognized in this area. The Weskan member, which overlies the Sharon Springs member, is believed to underlie the greater part of this area, although the exact dividing line between it and the Sharon Springs member has not yet been identified because of the poor condition of the exposures. The Lake Creek member, which overlies the Weskan member, has not been recognized in the area, but it probably is present in the western part of the Republican River valley in Nebraska. It is doubted that the Salt Grass member, which overlies the Lake Creek member, crops out in the region. The thickness of the Pierre shale in this area ranges from a featheredge to as much as 1,500 feet.

Examination of the exposures of the Pierre shale and logs of wells revealed that the Pierre shale is relatively impermeable and, except for joints and fissures, will not yield appreciable amounts of ground water. Wells drilled into this formation south of McCook yield very little water, and most of these wells have been abandoned. In this locality, the ove rlying Ogallala formation has been drained by small valleys that have cut through it into the Pierre shale, and, as a result, the water table has been lowered until it is near the contact of the Pierre shale and the overlying Ogallala formation. In some places the flow of water along this contact or through joints in the shale could be intercepted by wells, but the amount of water obtained probably would be very small. Well drillers throughout the valley generally stop drilling when the Pierre shale is reached because the amount of water obtainable from this formation is generally insufficient to justify deeper drilling. 
GROUND-WATER GEOLOGY, REPUBLICAN AND FRENCHMAN VALLEYS, NEBR. 605

\section{TERTIARY SYSTEM}

\section{PLIOCENE SERIES}

\section{OGALLALA FORMATION}

The Ogallala formation is exposed along the sides of the Republican River valley and along the floor and sides of the tributary valleys. Exposures are plentiful because parts of the Cgallala are indurated and are therefore resistant to weathering. The Ogallala formation consists of limy sand and sandstone, loesslike silt that may or may not be lime cemented, unconsolidated sand and gravel, beds of volcanic ash, and, in some places, opaline-cemented sandstone. Because of the range both laterally and vertically in the lithology of the Ogallala, it is difficult to correlate exposures; key beds, based on lithology, generally are reliable only in areas of a few square miles. Fossil seeds in a restricted part of the formation seem to be the only reliable means of correlation that are usable in larger areas, although an algal limestone bed near the top of the formation is relatively widespread and is considered by Elias (1931) to be of stratigraphic significance.

A dominant feature of the Ogallala formation is the presence in nearly all exposures of mortar beds that are more resistant to deterioration than the softer intervening rocks. The mortar beds are white, except where darkened by the growth of lichens, and are composed of fine to coarse sand and gravel. The sand is chiefly quartz, pink feldspar, and some basic minerals. Some of the gravel contains subangular to well-rounded pebbles of pink granite, basic porphyries, basalts, and gabbros; their presence in cross-laminated channels suggests deposition by streams. Some of the stratigraphically higher massive limy beds contain no gritty material and are characterized by pinkish whorls and concentric crusts that suggest either an organic or concretionary origin. The algal limestone, described by Elias (1931) as the topmost horizon, has not been definitely recognized in this area.

The unconsolidated stream-deposited sand is better sorted than the sand of the lime-cemented beds and is crossbedded in a pattern that indicates reworking of the deposits in the channels. Much of the gravel and sand contains iron oxide, which has stained some particles green and some red. The other sand is brown when wet and changes to gray as it dries. The channel sand crumbles easily when exposed. It is probable that the dune sand and gravelly soils on the floor of the main valleys were derived in part from the channel sand in the Ogallala formation. 
Within the horizontally bedded sand in many places are layers of giant concretions that are many feet long and that lie parallel to the bedding of the surrounding rock. These concretions are calcareous and generally are enclosed in a light-green dense opaline sandstone. The upper and lower contacts of this zone of dense cementation usually are irregular and do not coincide with any bedding planes, but cross them at small angles. The opaline sandstone grades laterally into a concretionary zone or into limy or unconsolidated sand. This silicified sandstone is more resistant to weathering than the mortar beds and, where exposed, appears as a hard undulant ledge of green vitreous rock, generally from 6 inches to 3 feet thick. In the vicinity of Medicine Creek dam, the maximum thickness of the opaline sandstone is about 6 feet. The aggregate thickness of the Ogallala formation in this area ranges from a featheredge to about 400 feet.

The Ogallala formation is a source of abundant supplies of ground water, both for irrigation and domestic use. However, yields differ considerably because of the difference in the permeability of the water-bearing materials. The water is moderately hard but is not mineralized to the extent that taste or color are affected or its use for irrigation impaired.

\section{QUATERNARY SYSTEM}

\section{PLeistocene series}

\section{HOLDREGE AND GRAND ISLAND FORMATIONS, UNDIFFERENTIATED}

Sand and gravel of the Holdrege and Grand Island formations, which are of the same age as the Nebraskan and Kansan till sheets, are believed to be present as fill in the ancestral Republican River trough and on the north side of the valley. These formations, the aggregate thickness of which ranges from a featheredge to about 80 feet, consists principally of sand and gravel and are mantled, except in a few places, by finer grained materials of later Pleistocene and Recent age. In this report no attempt has been made to indicate on the logs of the test holes and wells the contact between the Holdrege and Grand Island formations or the contact of these earlier sediments and those deposited later. Irrigation and domestic water supplies of good quality are obtained from the Holdrege and Grand Island formations.

\section{SAPPA FORMATION}

The Sappa formation, which overlies the Grand Island formation, is relatively sof $t$ and unconsolidated. It is believed to be of 
Yarmouth age and to antedate the advance of the Illinoian continental glacier into states farther east. Most of the exposures are deeply weathered, but the formation is well exposed in a few places high on the wall of the Republican River valley.

The Sappa formation consists of greenish-gray sandy clay of fluviatile origin. Generally, a distinct bed of volcanic ash, known as the Pearlette ash member, underlies the clay and fine silt. The total thickness of the Sappa formation in this area is less than 25 feet in most places, but at Eustis, Nebr., which is 23 miles north of Holbrook, the Pearlette ash member alone is more than 15 feet thick.

The Sappa formation is relatively impermeable and is not considered to be a source of ground water.

\section{CRETE FORMATION}

The Crete formation is composed principally of poorly sorted and crossbedded clean sand and gravel and some massive beds of siltstone and clay. The formation also includes beds of large boulders that were derived chiefly from the Ogallala and Niobrara formations and which show little evidence of having been weathered or transported prior to their deposition. The poor sorting and the large size of the boulders indicate that the Crete formation in this region is composed wholly of materials of local origin. When the Crete formation was being deposited, talus from exposed bedrock provided the material that was reworked by fluvial action into then existing depressions. The deposition of fine-grained material in some places indicates the ponding of muddied waters in the boulder-choked stream courses. The sand and gravel is chiefly pink feldspar and quartz grains derived from the Ogallala formation.

The Crete formation is exposed in the area where the streams have cut steep-walled canyons into the north wall of the Republican River valley. Most of the exposures resemble talus slopes because the formation contains such a high proportion of sand, cobbles, and boulders.

In this area, the Crete formation ranges in thickness from a featheredge to about 20 feet. As it is very permeable and is generally above the water table, recharge from precipitation passes easily through it to the zone of saturation below. 
Between the Crete formation and the overlying Loveland loess is a transitional zone of stratified reddish silt and sand that grades upward into the Loveland loess. This transitionalzone is probably the result of the reworking by surface water of the upper part of the Crete formation and eolian silt.

\section{LOVEL AND FORMATION}

The Loveland formation is composed of loess and is easily recognized because of its pinkish hue. It is useful as a reference horizon for older and younger fluvial formations that otherwise would be somewhat difficult to distinguish from each other. In the area described in this report, the Loveland formation mantles the bedrock or earlier Pleistocene formations. In this area the best exposures of the formation are found in road cuts and gullies. Its vertical columnar structure permits the loess to stand as bluffs along parts of the Republican River valley.

The Loveland formation consists of reddish-brown silt intermixed with lesser amounts of clayey material and sand. In some places the lower part of the loess is stratified. Directlyabove the contact of the loess with the underlying sand and gravel of the Crete formation is a thick zone of concretions similar to those present in the Peorian loess. The concretions are principally of the ramose nodular variety and the fragile tubular type that resembles calcified plant stems and roots.

Erosion of the Loveland formation after its deposition resulted in an undulating upper surface, which in many places is marked by a "fossil" soil zone. This buried soil is widely known and referred to as the Loveland soil or "Citellus zone." The soil does not possess a well-defined $A$ horizon, but the $B$ horizon is a distinct highly calcareous prismatic clay. White limy material is distributed throughout the $B$ horizon in the form of white specks that average from 2 to 5 millimeters in diameter. The concentration of calcareous matter in the $B$ horizon suggests a soil origin for the concretions present in the lower part of the formation. The Loveland soil itself is a good stratigraphic horizon because it marks the top of the Loveland formation and represents a period of exposure and weathering before the deposition of the overlying Peorian loess. The surface upon which this soil was formed was hilly or rolling and in places was cut by deep ravines. Several prismatic clay and calcareous zones, similar to those in the $B$ horizon of the Loveland soil, are present in the Loveland formation. As these zones are not as distinctive as those in the $B$ horizon, they do not detract from the value of the Loveland soil as a key horizon. The thickness of the Loveland formation in this 
area ranges from a featheredge to about $6 \mathrm{l}$ feet. The principal hydrologic function of the Loveland loess in this area is that of transmitting water downward to the water table. However, where saturated, the Loveland may yield a small amount of water to wells.

\section{PEORIAN LOESS}

The Peorian loess mantles both valley walls of the Republican River valley. As it overlies all other formations except the Bignell loess and Recent alluvium, it is the most widely exposed formation in this area. Freshets and small streams cut in to it easily.

The topography formed on the Peorian loess is almost wholly the result of erosion by water. In the uplands the surface of the loess is generally broken into a series of short steplike bluffs. Near large streams the bluffs become high and clifflike and are dissected into prominences and pinnacles. In the lower part of the valley, the meandering action of the river has terraced the loess. The subsequent downcutting of the river has left the terraces at higher levels than the present drainage.

The Peorian loess in this region is uniformly gray to buff. It consists chiefly of silt in which some sand and clay are interspersed. The upper part of the loess is massive, and its structure is characteristically columnar. Many concretions are present; some are nodular and tuberculate, and others are fragile and stemlike. The nodular concretions are the larger, and they are usually concentric in structure and oriented in horizontal bands. They are composed of calcareous material and, because of their superior cementation, commonly jut out of a wall of loess. Stream beds that have been cut into bluffs where these concretions are abundant are littered with them. The loess matrix, although calcareous, is poorly cemented and is easily leached by surface and ground waters.

The Peorian loess is characterized by a number of well-defined soil zones. A few of these zones are as much as 3 feet thick, but the majority are less than a foot thick. Soil formation on the surface of the Peorian loess is dependent largely on the condition of the slopes and on vegetation. The soil is about 8 to 12 inches thick in the area described by this report. In contrast with the light gray of the loess, zones of fossil soil within the loess are dark and are leached in their upper part. Gastropod shells are common in the fossil soils, and, because the gastropods were gregarious in habit, the shells are either very abundant or completely absent. Stratified zones characterized by dark streaks 
are present in the lower part of the Peorian loess. The dark streaks probably are thin soils or slope wash derived from soil exposed nearby. A stratified zone is rarely overlain by massive unstratified loess; it probably represents fluvial deposition in valleys dissected during an earlier eolian phase. The thickness of the Peorian loess in this area ranges from a featheredge to as much as 60 feet.

The hydrologic function of the Peorian loess is similar to that of the Loveland, and it also is a possible source of water where saturated. The rolling topography of the Peorian loess is conducive to high runoff of precipitation, particularly that occurring as heavy showers in areas where the native vegetation had been denuded by overgrazing or improper cultivation. As a result, much water needed for the growth of vegetation is lost, and the recharge to underlying aquifers is correspondingly less.

\section{SAND AND GRAVEL OF LATE WISCONSIN AGE}

The Republican River valley was eroded rather deeply and refilled with alluvial sediments several times during and following the deposition of the Peorian loess. This period of repeated downcutting and subsequent aggradation resulted in the formation of the several terraces along the Republican River. The deposits of sand and gravel that underlie these terraces and the younger deposits (Bignell loess and Recent alluvium) are saturated and are the source of abundant water supplies. The deposits range in thickness from a featheredge to about 50 feet.

\section{PLEISTOCENE AND RECENT SERIES}

\section{BIGNELL LOESS}

The Bignell loess mantles the intermediate and lower terraces, and in places on the uplands it overlies the Peorian loess. This loess is very similar to the Peorian loess and consists of buff eolian silt. On the intermediate and lower terraces, the lower part contains clayey fluvial silt. The hydrologic function of this formation is chiefly that of a transmitting agent. It does not supply water to any wells in the area.

\section{ALLUVIUM}

Since late Wisconsin time the terrace deposits of earlier ages have been gradually eroded; this material, plus material eroded 
from the sides of the valleys, has been spread over the floor of the Republican River valley by the river during flood stage; and as a result, the present flood plain is about 5 feet higher than the normal river surface. The younger terraces also have been mantled by slope wash from the older and higher terraces. This material ranges from coarse talus to fine clay; however, the larger portion consists of silt and fine sand, which were derived from the easily eroded loess that caps the valley sides. The lack of forest cover and the reduction of soil-holding grasses accelerated the process of erosion. The eroded silt is spread uniformly over the valley floor to a depth ranging from a few inches to 10 feet and mantles much of the sand and gravel of earlier deposition. The fill of the smaller stream valleys and canyons is chiefly silt, which contains many cobbles, pebbles, gravel, and sand. The amount of disintegrated material has been too great for the streams to transport, and the resultant flat-bottomed draws now reach far into the divide. The steep walls of these draws and the wide valley flats are characteristic of this region.

Most wells in the Republican River valley tap the older, more permeable sand and gravel; but in the smaller tributary valleys and draws, the Recent alluvium is the common aquifer for stock and domestic wells. Wells in the alluvium are shallow and of ten go dry; many have been abandoned. As the thickness and extent of the aquifer is limited by the bedrock floor and the valley sides, the ground-water supplies are dependent on local precipitation.

A geologic section of the Republican River valley a mile west of McCook (see pl. 38) shows the great quantity of unconsolidated material filling the shallow trough that has been cut into the Pierre shale and the relationship of this valley fill to the bedrock formations underlying the valley sides. The profile of the water table also is shown in the cross section.

The floor of the valley is shown in the cross section to be underlain to a depth of 6 to 10 feet by terrace deposits of silt. The terraces, however, are poorly defined. Underlying the terrace deposits are widespread beds of sand, gravel, and clay. On the north side of the valley a definite shelf is cut into the Pierre shale. Both sides of the valley are mantled by the Peorian loess and the Loveland formation, and Tertiary formations underlie the loess mantle on the south side of the valley.

The geologic section is based on the logs of test holes drilled in 1939 in connection with the cooperative Federal-State groundwater program and on the logs of hand-augered testholes and observation wells installed in 1950. The position of the water table 
is based on measurements made in October 1950 of the water level in observation wells near the line of the geologic section.

\section{GROUND WATER}

\section{OCCURRENCE}

Large quantities of ground water are available throughout most of the Republican River valley in Nebraska. Alluvial deposits of sand and gravel underlying the present valley act both as excellent conduits and as large storage reservoirs for ground water. Generally, the thickness of the sand and gravel is greatest near the center of the valley. The zone of saturation in most places near the center of the Republican River valley is 40 to 60 feet thick, and in a few places it is a little more than 60 feet thick. Near the valley sides, however, the thickness of the zone of saturation ranges from less than a foot to about 20 feet. The thickness of the saturated water-bearing materials in the valleys of the Republican River and its principal tributaries is shown on maps published by Waite, Reed, and Jones (1946).

Although the quantity of water in the Ogallala and other formations under the valley slopes of the Republican River and the tributary streams differs considerably from place to place, adequate supplies generally are available for domestic and stock use.

\section{RECHARGE}

Recharge to the ground-water reservoir from precipitation occurs frequently throughout the Republican River valley. The alluvial material underlying the topsoil facilitates rapid recharge, and where the water table is less than 10 feet below the land surface, a rise in ground-water level of ten is noticeable within a day or two after heavy showers. In the Frenchman River valley, however, the depth to water is more than 10 feet and recharge from rainfall is much less rapid.

Melting snow and ice also recharge the ground-water reservoir. The amount of recharge from this source, however, is not very great because the snowfall in this area usually is relatively light. Recharge from snowmelt is probably greatest where the snow has accumulated in drifts along roads and fences.

The condition of the soil is a governing factor in the amount of precipitation that will infiltrate to the ground-water reservoir. Soil that is finely tilled often becomes a slick, almost impervious 
surface when wet, and a large proportion of the rainfall on such surfaces runs off as surface water. Untilled land covered by abundant vegetation, however, tends to retain its original porous structure; water enters it easily, and that not retained by the soil or absorbed by plants infiltrates to the zone of saturation.

In stretches where it is influent, the Republican River contributes to the ground-water reservoir underlying the flood plain. For example, about 1 mile southwest of McCook the Republican River is a losing stream, a condition shown by both the geologic section (pl. 38) and the water-table contour map (pl. 39). The North Fork of the Republican River has built up natural levees that have raised the level of the river higher than that of the water table adjacent to the river, thus causing the river to lose water to the ground-water reservoir. An indication of ground-water recharge from the river is shown in figure 78. Well 1-41-20dd is situated several miles east of the North Fork gaging station, well 3-31-17cd is about 2 miles southeast of the Frenchman River gaging station, and well $2-19-28 \mathrm{dd}$ is about $2 \frac{1}{2}$ miles southeast of the Orleans gaging station. If the changes of the water level in these wells were due to recharge from local precipitation, they probably would not correlate so closely with the rise and fall of the river which necessarily reflects the amount and distribution of precipitation over its entire drainage basin.

The quantity of recharge by underflow from the upland areas to the Republican River valley is undetermined and would be difficult to estimate.

Conclusive evidence of ground-water recharge from the north was shown by Lugn and Wenzel (1938, pls. 9 and 14). Their publication showed that eight streams between Edison and Alma flow continuously in their lower reaches as a result of ground-water discharge and that most of this flow was derived originally from the Platte River valley. Contour lines on the water table, as drawn by Lugn and Wenzel, indicate southeasterly movement of ground water into the Republican River valley between Cambridge and the eastern edge of the area described in this report. The permeable layers of the Ogallala formation and the sand and gravel of Pleistocene age underlying the loess plain north of the river transmit the ground water. Recharge to the valley from the uplands to the south is believed to be relatively small compared to the recharge from the north because of the southerly slope of the underlying impermeable bedrock surface and the thinness of the zone of saturation of the Ogallala formation.

A large part of the ground water entering the Republican River valley is through the fill of the tributary valleys. Most of the 


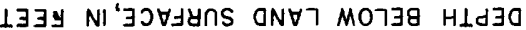

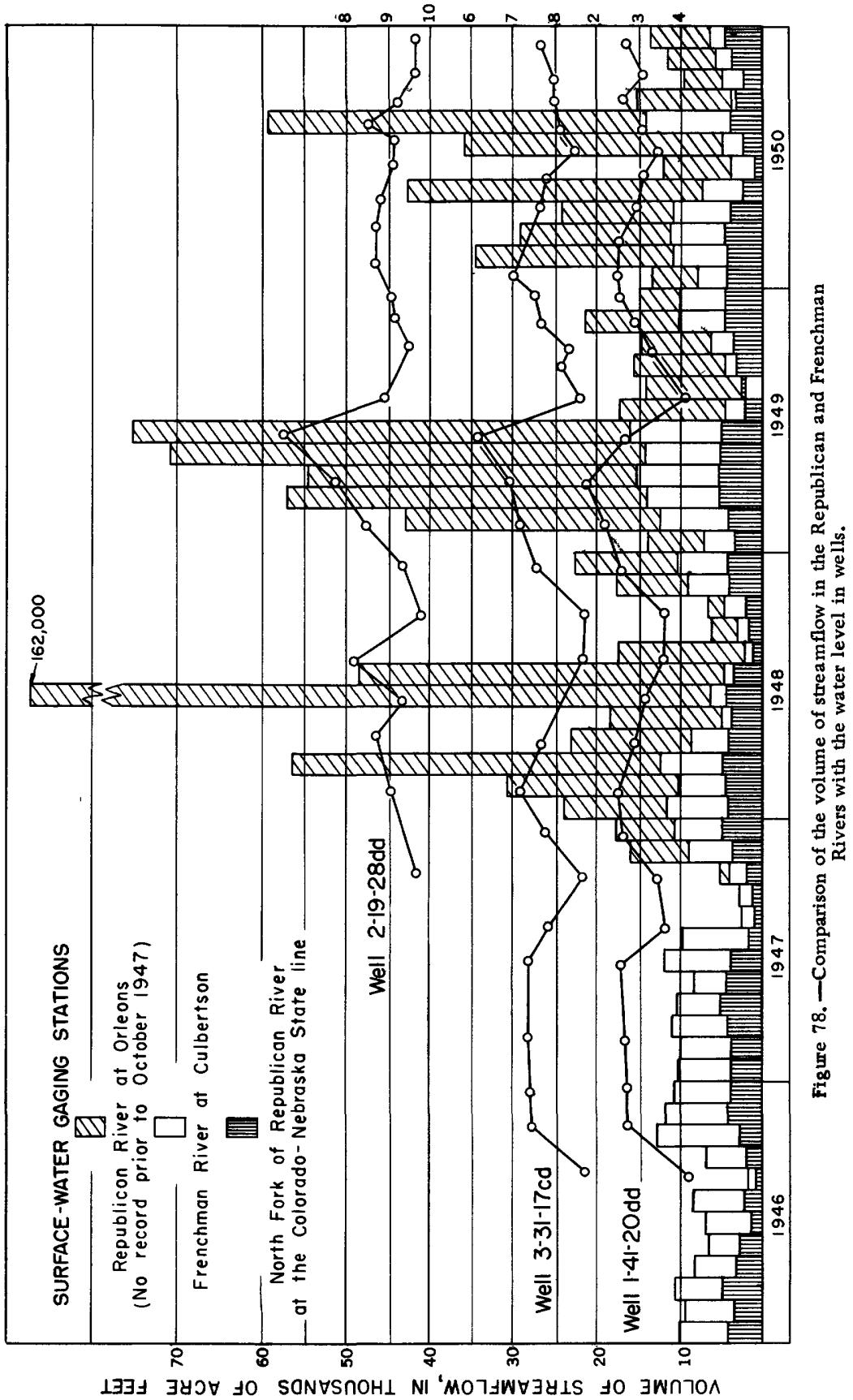


underflow west of Culbertson is through the valleys of the North and South Forks of the Republican River and the valley of the Arikaree River. East of Culbertson, the underflow is from the valley of the Frenchman River.

\section{DISCHARGE}

Evapotranspiration.-A large amount of ground water in the Republican River valley is discharged naturally by evaporation, transpiration, and effluent streams. Direct evaporation from the saturated zone occurs on the flood plain where the water table is close to the land surface. These areas are described elsewhere in this report. Extensive stands of willow and cottonwood trees along the banks of all major streams in the area transpire large quantities of water during the growing season. Alfalfa also transpires much ground water. Other crops and nonbeneficial phreatophytes directly consume water from the zone of saturation.

Seepage into streams. - Ground water is discharged into surface streams in many places in the Republican River valley. The net gain to the river is linked closely to seasonal changes, and without intensive quantitative study it would be impossible to determine the amount of natural discharge of ground water into the Republican River.

The Frenchman River is believed to be almost entirely an effluent stream with respect to ground water because (1) the surface flow of the river is comparatively constant from season to season; (2) the water-table gradient, as shown by the water levels in wells, generally is toward the stream from the valley walls; and (3) although the flow of the Frenchman River was impounded by the closing of Enders Dam in October 1950, a steady flow in the river channel reappeared at a point 3 to 4 miles downstream from the dam. It is possible, of course, that part of the ground-water discharge may again be returned to the zone of saturation by the Republican River in places where the river is losing water to the ground-water reservoir.

Springs and seeps. - On the north side of the Republican River valley west of the mouth of the Frenchman River, springs and seeps issue from the Ogallala formation where ground water is channeled toward the valley walls either by impermeable beds within the Ogallala formation or by the surface of the underlying Pierre shale. During the warm season, most of this water is evaporated or transpired. On the south side of the valley the discharge of ground water from springs and seeps is less than that on the nor th side. 
Underflow out of the area. - A large volume of ground water moves out of the area as underflow to the east through the valley fill. No quantitative determination of the amount has been made.

Wells. - Ground water is discharged by wells of many types throughout the valleys of the Republican River and its tributaries. Most of the municipal and irrigation wells are in the valleys, whereas domestic and stock wells are situated both on the upland and in the valleys. The withdrawal of ground water for domestic and stock use is small compared with that for public supply and irrigation. The average daily consumption of water by towns in the two valleys, with the exception of McCook, ranges from about 1,000 to 300,000 gallons, and the daily average for McCook during 1950 was $1,124,557$ gallons. Irrigation wells are not concentrated anywhere in the valleys of the Republican or Frenchman Rivers to the extent that water levels have been excessively lowered by pumping. The yield of a well depends on the depth to water and the permeability and thickness of the saturated materials penetrated by the well. In addition, the yield of some wells is limited by the capacity of the pump. The yields of irrigation wells in the Republican River valley range from 500 to $1,500 \mathrm{gpm}$ (gallons per minute). Wells in the wider parts of the valley generally yield more than those in the narrower parts.

\section{DIRECTION OF MOVEMENT}

Most of the ground water in the valleys of the Republican and Frenchman Rivers moves obliquely toward the river in a downstream direction. (See pl. 39.) Minor shifts in the direction of movement result from seasonal atmospheric changes, changing stages of the river, and seasonal changes in the vegetation,

The direction of movement of ground water underlying the uplands bordering the Republican and its tributary valleys has not been precisely determined. A water-table contour map of the area between the Republican and Platte Rivers east of Cambridge (Lugn and Wenzel, 1938, pl. 8) shows that the direction of movement is southeasterly in the area immediately north of the Republican River valley between Cambridge and Arapahoe and nearly due south in the area lying between Arapahoe and Alma. It is probable that the ground water under the uplands north of the Republican River valley between Cambridge and Culbertson moves in a southeasterly direction. 


\section{CONFIGURATION OF THE WATER TABLE}

The water table is "the upper surface of the zone of saturation in ordinary permeable:soil or rock" (Meinzer, 1923, p. 30). The relief on this surface depends on the ratio of recharge to discharge and on the permeability and specific yield of the aquifer. The configuration of the water table is also affected significantly by the configuration of the underlying bedrock floor.

The major slope of the water table in the Republican River valley is downstream. However, the maximum gradient in a given place is rarely parallel to the axis of the valley or to the meanders of the stream. The configuration of the water table in the valley conforms, in general, to the configuration of the land surface. Where the valley sides are gently sloping, the water table is gently inclined. Conversely, where the valley sides are steep or precipitous, the water table also has a relatively high gradient. Small hills and depressions do not have an appreciable effect on the contour of the water table. Surface drainage, however, is closely linked with the position of the water table in the Republican River valley. A high water table is generally present in the valley beneath poorly drained sandy and hummocky areas where recharge to the ground-water reservoir is relatively large.

In areas of shallow ground water, transpiration by vegetation may lower the water table. Declines of the water level have been observed in wells near alfalfa fields, timbered areas, and areas of other phreatophyte growth. In some areas, transpiration losses from timber-covered river islands have been large enough to lower the water table below the water level of the surrounding river. Pumping for irrigation or for municipal and industrial water supplies may create local depressions of the water table. Conversely, where rivers are ponded by the construction of dams or where lakes form in undrained depressions, the surrounding water table generally is high. The yield of wells is affected to a marked degree by changes in the elevation of the water table.

In some stretches the Republican River contributes to the aquifer through which it flows and in other stretches the flow of the river is sustained in part by ground water moving into the stream from the sides. In places where the river is in approximate equilibrium with the adjoining water table, slight changes in the elevation of the water surface of the river can cause the river to be a gaining stream during low flow and a losing stream during high flow. Ground-water movement is always in the downslope direction of the water table. 
In some places, such as in a stretch of the river southwest of Indianola, the water table slopes toward the river on one side of the river and away from the river on its opposite side. Thus the relationship between the Republican River and the adjoining water table is affected by channel characteristics, valley topography, drainage, and the amount of recharge and discharge to the groundwater reservoir. Typical profiles of the water table across the Republican River valley are shown in plate 41 .

Where Driftwood Creek enters the valley of the Republican River, it flows upon a thick body of impervious clay and has no direct connection with the underlying zone of saturation. (See geologic section $A-A^{\prime}$, pl. 38.) As the piezometric surface, projected from the water level in adjacent wells, is about 14 feet below the stream bed, it seems reasonable to conclude that there is no transfer of water from the stream to the ground-water reservoir in this region.

\section{DEPTH TO WATER}

The configuration of the water table (pl. 39) is similar to the topography of the land surface. The topographic relief of the land surface, however, greatly exceeds the relief of the water table. Generally, the depth to water in topographically low areas is less than in adjacent higher areas, but locally the depth to water may be abnormally shallow in regions of high recharge or poor subsurface drainage regardless of the elevation of the land surface. The depth to water in the Republican River valley is shown in plate 40 .

Generally, the water table is less than 10 feet beneath the surface of the flood plain and the lowest terraces, but toward the valley walls the depth to water increases beneath successively higher terraces. Where the meanders of the river have cut into the higher terraces or into the valley walls, the depth to water is about equal to the height of the land surface above the river.

Some of the land in areas of shallow water table is cultivated. If these areas are irrigated from surface sources, seepage from the canals and from irrigation probably will cause the water table to rise and, unless preventive measures are used, some of the land may become waterlogged or otherwise damaged. Deposition of salts on the land surface, resulting from evaporation of water brought near the land surface by capillary action, occurs in the following areas:

$\mathrm{N} \frac{1}{2}$ sec. 5, T. $3 \mathrm{~N} .$, R. $25 \mathrm{~W}$.

Sec. 8, T. 3 N., R. 26 W. 
Secs. 2, 10, and 11, T. 3 N., R. 27 W. (between Highway 6-34 and the terrace about one-fourth of a mile north)

$\mathrm{N} \frac{1}{2}$ sec. 31, T. $3 \mathrm{~N}$., R. $29 \mathrm{~W}$.

$\mathrm{S} \frac{1}{2}$ secs. 20 and 21 , and $\mathrm{N} \frac{1}{2}$ secs. 28,29 , and 36, T. 3 N., R. $30 \mathrm{~W}$.

$\mathrm{S} \frac{1}{2}$ sec. 15 and $\mathrm{N} \frac{\mathrm{l}}{2}$ sec. 22 , T. 3 N., R. $31 \mathrm{~W}$.

$\mathrm{S} \frac{1}{2}$ sec. 26 and $\mathrm{N} \frac{1}{2}$ sec. 33, T. 3 N., R. $32 \mathrm{~W}$.

$\mathrm{S} \frac{1}{2}$ sec. 20 and central parts of secs. 25 and 26, T. 4 N., R. $24 \mathrm{~W}$.

S $\frac{1}{2}$ sec. 32 , sec. 33 , and $N \frac{1}{2}$ sec. 34, T. 4 N., R. 25 W.

Anomalies of drainage or of geology are responsible in some places for the comparatively shallow depth to water below the higher terraces. In some places the water table is close to the land surface at the junction of the steep bluffs and the valley floor because the water table is almost tangent with the land surface. The existing network of observation wells is not sufficient to indicate the extent of the areas of shallow water table, but springs on the valley walls are evidence that the water table intersects the land surface at those points. An area of shallow depth to water is shown in the geologic section $A-A^{\prime}$ (pl. 38) at test hole 2-30-13aa. Other similar areas of shallow water table are-

$\mathrm{S} \frac{1}{4}$ sec. 16 and $\mathrm{N} \frac{1}{2}$ sec. 17, T. 3 N. , R. $30 \mathrm{~W}$.

$\mathrm{S} \frac{1}{2}$ sec. 25, T. 4 N., R. $22 \mathrm{~W}$.

$\mathrm{S} \frac{1}{2}$ sec. $16, \mathrm{~T} .4 \mathrm{~N} .$, R. $23 \mathrm{~W}$.

S $\frac{1}{2}$ sec. 13, T. 4 N. , R. 24 W.

Several areas in the Republican River valley are underlain by comparatively thick unsaturated material. For example, near Drif twood Creek (near the center of sec. 12, T. 2 N., R. 30 W.) a thick body of clay is present above the water table, and because it is relatively impervious the recharge to the underlying zone of saturation is slight. North of Arapahoe, where surface runoff is carried away rapidly by Muddy and Elk Creeks, the water table also is relatively deep.

The principal tributary streams to Frenchman River are Stinking Water Creek, Sand Creek, and Spring Creek. These streams flow in narrow valleys and, like the Frenchman River, generally are bordered by narrow terraces. The geology and ground-water conditions in the tributary valleys are similar to those in the Frenchman River valley.

\section{FLUCTUATIONS OF THE WATER TABLE}

The ground-water reservoir in the Republican River valley has definite bottom and lateral limits but usually has no confining 
upper boundary. Consequently, any change in the volume of the stored water is represented by a change in the elevation of the water table.

The movement of ground water within the reservoir is limited by the small size of the openings in the rock and soil material through which it passes. For this reason, the water-level fluctuations in wells are not as sudden as water-level changes in bodies of surface water after rains.

The locations of water-level observation wells are shown on plate 37. Measurements made of the water level in these wells during this investigation are given in Appendix $A$ and records of all wells for which information was available are given in Appendix. B. During 1949 and 1950, periodic water-level measurements in most of the observation wells in this area were made on a monthly or bimonthly basis; however, measurements of the water levels in a few wells were made weekly. Several of the wells were equipped with recording gages that provided a continuous record of the water-level fluctuations.

Water-level measurements made in the area since 1934 show a general rise of the water level in these wells during recent years. (See hydrographs of wells 3-27-8ac, 2-35-21bc, and 2-18-33cd in pl. 42.) Hydrographs showing water-level fluctuations in several wells during the period 1946-50 (pl. 43) show a decline of the water level in the fall and a rise in the spring and early summer. These are seasonal fluctuations caused by variations in the amount and distribution of the precipitation, by changes in temperature, which are reflected in changes in rates of evapotranspiration and pumping from wells, and by other factors that control groundwater recharge and discharge. Water-level fluctuations of ten differ noticeably in wells in adjacent localities.

Several wells were installed by the Bureau of Reclamation in the vicinities of Enders, Medicine Creek, and Trenton Reservoirs in order to observe the effect of the filling of those reservoirs upon adjacent water levels. A comparison of the water surface of Enders Reservoir with water levels in nearby observation wells is shown in figure 79, and a comparison of the water surface of Medicine Creek Reservoir with water levels in nearby observation wells is shown in figure 80. The rise of the water level in the wells near Enders Reservoir was about one-half to two-thirds the rate of the rise of the water surface of the reservoir. This indicates that the material surrounding and underlying the reservoir in the vicinities of these wells is permeable and becomes saturated rather rapidly. Enders Rese rvoir was closed for filling October 24, 1950 , and water-level measurements in wells were in progress 
GROUND-WATER GEOLOGY, REPUBLICAN AND FRENCHMAN VALLEYS, NEBR. 621

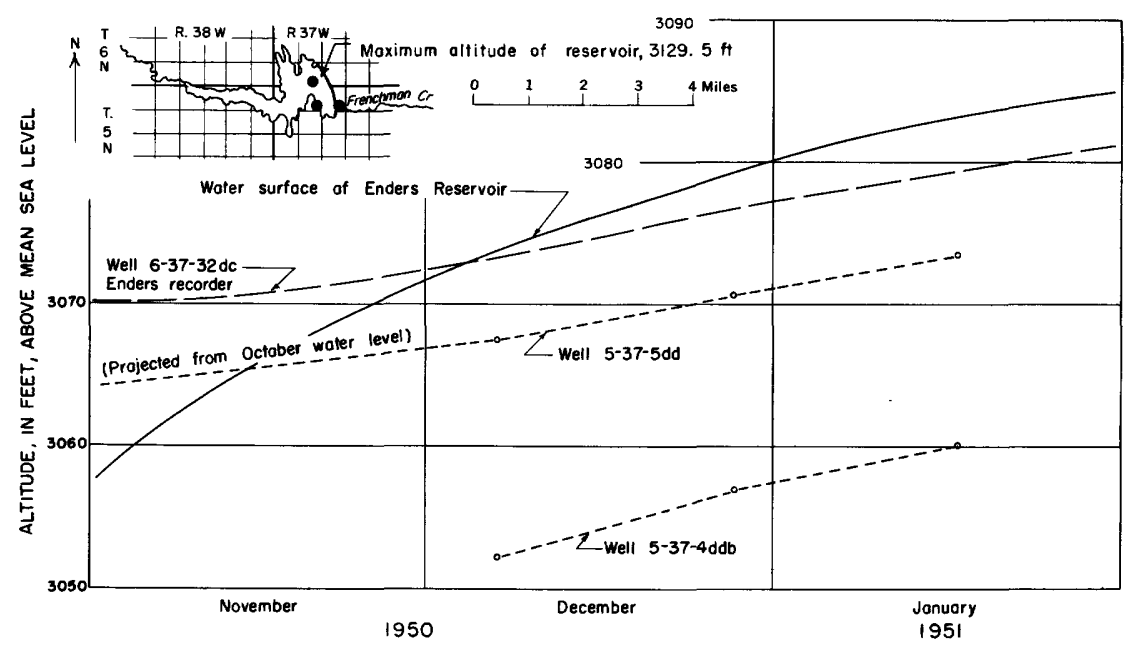

Figure 79. - Comparison of the water surface of Enders Reservoir with the water level in nearby wells.

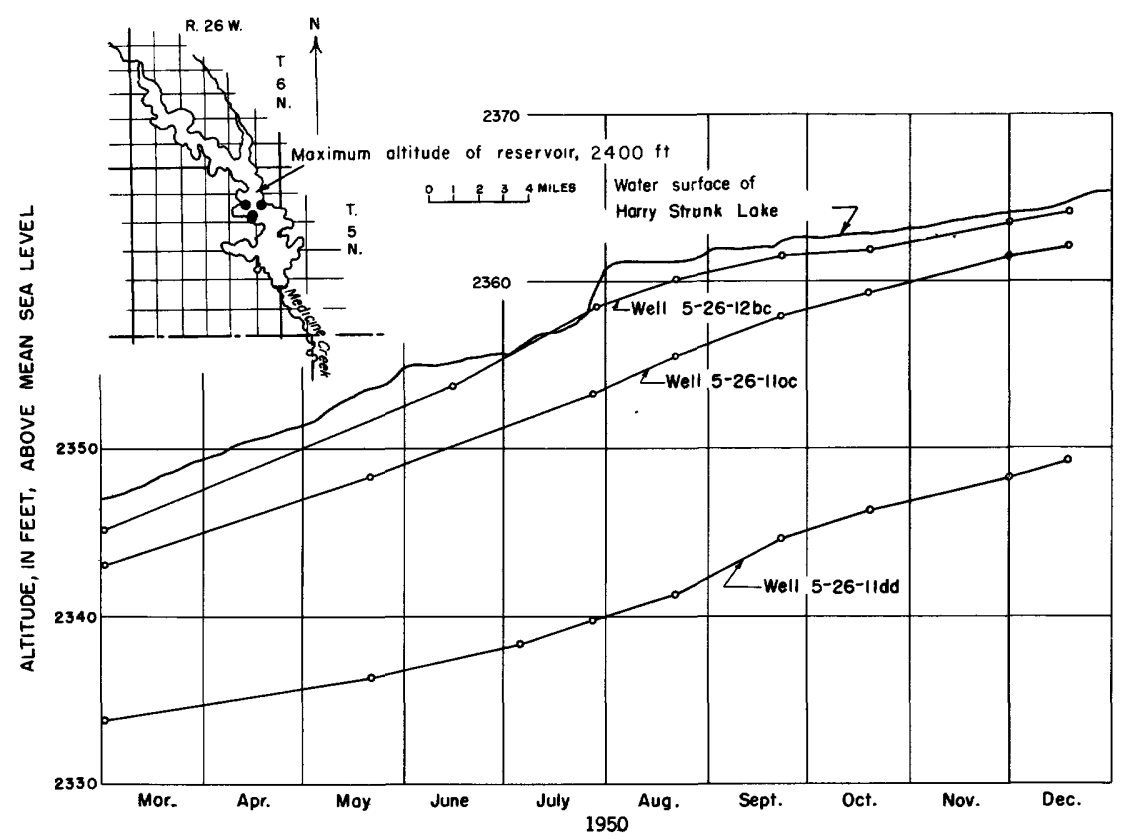

Figure 80. - Comparison of the water surface of Medicine Creek Reservoir with the water level in nearby wells. 
for more than a year prior to that date. High bank storage is indicated in figure 80 by the rate of rise of the water level in wells adjacent to Medicine Creek Reservoir. This rate closely parallels the rate of rise of the water surface of the reservoir. This condition likewise indicates the existence of permeable materials between the bed of the reservoir and the aquifer tapped by the wells. Medicine Creek Reservoir was closed for filling August 10, 1949, but measurements in wells were not started until March 1950.

Water-level records of wells that are equipped with recording gages often show diurnal fluctuations caused principally by changes in the rates of evapotranspiration and by changes in atmospheric pressure. These variations generally are slight. A well situated near a municipal well field, however, may show extreme diurnal fluctuations because of the great difference in the daytime and nighttime pumping rates.

In general, water-level fluctuations in a deep well are small compared to those in a shallow well in which the water level is

Mineral constituents and related

[Analytical results in parts per

\begin{tabular}{|c|c|c|c|c|c|c|c|c|c|c|c|}
\hline $\begin{array}{c}\text { Well } \\
\text { no. }\end{array}$ & $\begin{array}{c}\text { Date } \\
\text { of } \\
\text { collection }\end{array}$ & $\begin{array}{c}\text { Tem- } \\
\text { pera - } \\
\text { ture } \\
\left({ }^{\circ} \mathrm{F}\right)\end{array}$ & $\begin{array}{l}\text { Silica } \\
\left(\mathrm{SiO}_{2}\right)\end{array}$ & $\begin{array}{l}\text { Total } \\
\text { iron } \\
\text { (Fe) }\end{array}$ & $\begin{array}{l}\text { Man- } \\
\text { ga- } \\
\text { nese } \\
\text { (Mn) }\end{array}$ & $\begin{array}{l}\text { Cal- } \\
\text { cium } \\
\text { (Ca) }\end{array}$ & $\begin{array}{c}\text { Mag- } \\
\text { ne- } \\
\text { sium } \\
(\mathrm{Mg})\end{array}$ & $\begin{array}{l}\text { So- } \\
\text { dium } \\
\text { (Na) }\end{array}$ & $\begin{array}{c}\text { Po- } \\
\text { tas- } \\
\text { sium } \\
(\mathrm{K})\end{array}$ & $\begin{array}{c}\text { Bicar- } \\
\text { bon- } \\
\text { ate } \\
\left(\mathrm{HCO}_{3}\right)\end{array}$ & $\begin{array}{l}\text { Car- } \\
\text { bon- } \\
\text { ate } \\
\left(\mathrm{CO}_{3}\right)\end{array}$ \\
\hline $\begin{array}{l}1-37-19 a a \\
1-38-21 c b \\
1-40-26 a a \\
1-41-27 c d \\
2-18-33 a c\end{array}$ & $\begin{array}{lr}\text { May } & 2,1947 \\
\text { Dec. } 17,1936 \\
\text { May } 1,1947 \\
\text { April } 30,1947 \\
\text { May } 25,1947\end{array}$ & $\begin{array}{r}\cdots \cdots \cdots \\
54 \\
55 \\
56\end{array}$ & \begin{tabular}{|c|}
34 \\
$\ldots \ldots \ldots$ \\
40 \\
53 \\
53
\end{tabular} & \begin{tabular}{|c|}
0.02 \\
$\ldots \ldots \ldots$ \\
6.5 \\
4.0 \\
$\ldots \ldots \ldots$
\end{tabular} & $\begin{array}{c}\ldots \ldots . . . \\
\ldots \ldots . . . \\
\cdots \ldots . . . \\
0.0\end{array}$ & $\begin{array}{r}79 \\
66 \\
236 \\
221 \\
102\end{array}$ & \begin{tabular}{l|}
27 \\
22 \\
85 \\
74 \\
19
\end{tabular} & $\begin{array}{r}5 \\
13 \\
20 \\
10 \\
1\end{array}$ & $\begin{array}{l}6 \\
0 \\
5 \\
8 \\
7\end{array}$ & $\begin{array}{l}409 \\
424 \\
311 \\
339 \\
362\end{array}$ & $\begin{array}{l}0 \\
0 \\
0 \\
0 \\
0\end{array}$ \\
\hline $\begin{array}{l}2-19-21 d a \\
2-29-5 b c \\
2-33-2 a b \\
2-34-18 a a \\
2-36-29 a c\end{array}$ & $\begin{array}{l}\text { May } 24,1947 \\
\text { May } 22,1947 \\
\text { May } 1,1947 \\
\text {....do......... } \\
\text { May } 2,1947\end{array}$ & $\begin{array}{r}55 \\
\ldots \ldots \\
53 \\
53 \\
53\end{array}$ & $\begin{array}{l}40 \\
47 \\
40 \\
38 \\
33\end{array}$ & $\begin{array}{l}.20 \\
.80 \\
.20 \\
.02\end{array}$ & $\begin{array}{r}\quad .1 \\
.0 \\
\ldots \ldots \ldots \\
\ldots \ldots \ldots . . \\
\ldots \ldots \ldots\end{array}$ & $\begin{array}{r}144 \\
107 \\
97 \\
105 \\
68\end{array}$ & $\begin{array}{l}29 \\
28 \\
29 \\
40 \\
22\end{array}$ & $\begin{array}{r}36 \\
6 \\
6 \\
10 \\
4\end{array}$ & $\begin{array}{ll}0 & \\
1 & 29 \\
8 & \\
3 & \\
3 & \end{array}$ & $\begin{array}{l}418 \\
428 \\
397 \\
447 \\
285\end{array}$ & $\begin{array}{l}0 \\
0 \\
0 \\
0 \\
0\end{array}$ \\
\hline $\begin{array}{l}3-21-1 \text { aa } \\
3-21-12 a a \\
3-27-8 a c \\
3-27-18 b c 1 \\
3-31-17 a d\end{array}$ & $\begin{array}{lr}\text { Dec. } 11,1936 \\
\text { May } 24,1947 \\
\text { Dec. } 9,1936 \\
\text { May } 21,1947 \\
\text { May } 23,1947\end{array}$ & $\begin{array}{c}56 \\
56 \\
56\end{array}$ & $\begin{array}{c}51 \\
\ldots 7 \\
49 \\
49\end{array}$ & .... & $\begin{array}{c}\cdots . . . . . \\
\cdots \\
\cdots . . .0 \\
.0 \\
.0\end{array}$ & $\begin{array}{r}76 \\
105 \\
61 \\
108 \\
135\end{array}$ & $\begin{array}{l}16 \\
24 \\
21 \\
28 \\
36\end{array}$ & $\begin{aligned} & 2 \\
& 2 \\
& 1 \\
& 1 \\
5 & \end{aligned}$ & $\begin{array}{ll}6 & 18 \\
5 & \end{array}$ & $\begin{array}{l}330 \\
388 \\
284 \\
431 \\
368\end{array}$ & $\begin{array}{l}0 \\
0 \\
0 \\
0 \\
0\end{array}$ \\
\hline $\begin{array}{l}3-33-35 d c \\
4-23-23 b c \\
4-25-26 b b \\
4-26-36 a b \\
4-34-1 a b\end{array}$ & $\begin{array}{lr}\text { Dec. } & 6,1936 \\
\text { May } & 21,1947 \\
\text { Dec. } & 9,1936 \\
\text { May } & 22,1947 \\
\text { June } & 8,1947\end{array}$ & $\begin{array}{c}\ldots \ldots \\
56 \\
\ldots 5 \\
54\end{array}$ & $\begin{array}{c}\cdots 3 \\
34 \\
54 \\
64\end{array}$ & $\begin{array}{c}. \ldots . . . . . \\
\cdots \ldots . . . . \\
\cdots \ldots . . . . \\
.6\end{array}$ & $\begin{array}{c}\cdots \cdots \\
\cdots . .0 \\
.0 \\
.0 \\
.0\end{array}$ & $\begin{array}{r}102 \\
101 \\
84 \\
78 \\
56\end{array}$ & $\begin{array}{l}30 \\
26 \\
19 \\
17 \\
15\end{array}$ & $29 \stackrel{5}{3}$ & $\begin{array}{ll} & 23 \\
0 & \\
8.4 \\
0\end{array}$ & $\begin{array}{l}408 \\
355 \\
304 \\
259 \\
234\end{array}$ & $\begin{array}{r}0 \\
20 \\
0 \\
21 \\
8\end{array}$ \\
\hline $\begin{array}{l}5-36-11 a c \\
5-36-11 d c\end{array}$ & $\begin{array}{lr}\text { May } & 23,1947 \\
\text { Dec. } & 5,1936\end{array}$ & $\begin{array}{r}57 \\
\ldots \ldots . .\end{array}$ & 60 & $\ldots$ & $\begin{array}{r}.0 \\
\ldots \ldots \ldots\end{array}$ & $\begin{array}{l}52 \\
50\end{array}$ & $\begin{array}{l}14 \\
15\end{array}$ & 1 & 3 & $\begin{array}{l}218 \\
222\end{array}$ & $\begin{array}{l}4 \\
0\end{array}$ \\
\hline
\end{tabular}

${ }^{1}$ Determined constituents (bicarbonate converted to equivalent carbonate before summation). 
affected by river recharge, local precipitation, and plant transpiration. The fluctuations occur more slowly in wells tapping silt and fine sand than in wells tapping coarse sand and gravel.

\section{CHEMICAL QUALITY}

The report by Waite and others (1948) on the ground-water hydrology of the valleys of the Republican and Frenchman Rivers contained a section, prepared by $H$. A. Swenson, on the chemical character of the ground water. Swenson's discussion was based on the results of chemical analyses of 34 samples, 16 of which were collected in 1947 from wells in the report area. The present discussion is based on the analytical results obtained for these 16 samples and for 6 other samples that had been analyzed in 1936 . (See table below and pl. 37.) All samples were from wells tapping deposits of Quaternary age.

\section{characteristics of ground water}

million except as indicated]

\begin{tabular}{|c|c|c|c|c|c|c|c|c|c|c|c|c|}
\hline \multirow{2}{*}{$\begin{array}{l}\text { Sul- } \\
\text { fate } \\
\left(\mathrm{SO}_{4}\right)\end{array}$} & \multirow{2}{*}{$\begin{array}{l}\text { Chlo- } \\
\text { ride } \\
\text { (Cl) }\end{array}$} & \multirow{2}{*}{$\begin{array}{l}\text { Fluo- } \\
\text { ride } \\
\text { (F) }\end{array}$} & \multirow{2}{*}{$\begin{array}{c}\mathrm{Ni}- \\
\text { trate } \\
\left(\mathrm{NO}_{3}\right)\end{array}$} & \multirow{2}{*}{$\begin{array}{l}\text { Boron } \\
\text { (B) }\end{array}$} & \multicolumn{2}{|c|}{$\begin{array}{l}\text { Dissolved } \\
\text { solids }\end{array}$} & \multicolumn{2}{|c|}{$\begin{array}{l}\text { Hardness as } \\
\mathrm{CaCO}_{3}\end{array}$} & \multirow{2}{*}{$\begin{array}{l}\text { Per- } \\
\text { cent } \\
\text { sodi- } \\
\text { um }\end{array}$} & \multirow{2}{*}{$\begin{array}{c}\text { Sodium - } \\
\text { adsorp- } \\
\text { tion } \\
\text { ratio } \\
\text { (SAR) }\end{array}$} & \multirow{2}{*}{$\begin{array}{l}\text { Specific } \\
\text { conduct- } \\
\text { ance } \\
\text { (micro- } \\
\text { mos at } \\
25^{\circ} \mathrm{C} \text { ) }\end{array}$} & \multirow[b]{2}{*}{$\mathrm{pH}$} \\
\hline & & & & & $\begin{array}{c}\text { on } \\
\text { evapo- } \\
\text { ration at } \\
180^{\circ} \mathrm{C}\end{array}$ & Sum 1 & $\begin{array}{c}\text { Calcium, } \\
\text { magne- } \\
\text { sium }\end{array}$ & $\begin{array}{l}\text { Non- } \\
\text { carbon } \\
\text { ate }\end{array}$ & & & & \\
\hline 63 & 16 & 2.0 & 2.0 & & 525 & & 308 & 0 & 28 & 1.4 & 821 & 8.0 \\
\hline 163 & 11 & 1.1 & 3.6 & $\ldots$ & ....... & 606 & 255 & 0 & 53 & 3.6 & & \\
\hline 1,030 & 35 & 1.6 & 1.0 & ........ & 1,850 & 1,790 & 938 & 683 & 32 & 2.9 & 2,290 & 8.0 \\
\hline 708 & 52 & .8 & .8 & ........ & 1,440 & 1,390 & 856 & 578 & 22 & 1.6 & 1,830 & 7.9 \\
\hline 33 & 22 & .2 & 10 & 0.14 & 477 & ....... & 333 & 36 & 12 & .4 & 666 & 8.4 \\
\hline 105 & 55 & .2 & 6.0 & .10 & 711 & & 379 & 26 & 12 & .6 & 958 & 8.3 \\
\hline 131 & 30 & .6 & 20 & .25 & 658 & ...... & 382 & 31 & 23 & 1.3 & 953 & 8.3 \\
\hline 145 & 21 & .8 & 2.0 & ........ & 609 & ...... & 361 & 35 & 29 & 1.6 & 951 & 8.0 \\
\hline 214 & 39 & 1.4 & 4.0 & ........ & 765 & & 439 & 72 & 34 & 2.2 & 1,170 & 8.2 \\
\hline 99 & 8.7 & 1.4 & .2 & ........ & 420 & & 260 & 26 & 26 & 1.1 & 664 & 8.3 \\
\hline 18 & 6.0 & .4 & 1.8 & $\mid . . . . .$. & & 302 & 256 & 0 & 15 & .6 & & \\
\hline 56 & 32 & .4 & 8.0 & .09 & 524 & $\ldots . .$. & 361 & 43 & 11 & .5 & 766 & 8.4 \\
\hline 25 & 6.0 & .4 & 6.9 & ........ & $\ldots . .$. & 276 & 239 & 6 & 13 & .5 & & \\
\hline 119 & 17 & .6 & 3.0 & .05 & 600 & ....... & 385 & 32 & 24 & 1.2 & 856 & 8.1 \\
\hline 168 & 55 & .5 & 50 & .11 & 828 & ....... & 485 & 183 & 12 & .7 & 1,060 & 7.7 \\
\hline 93 & 29 & .7 & 24 & |....... & & 533 & 378 & 43 & 23 & 1.2 & & \\
\hline 77 & 28 & .6 & 6.0 & .08 & 538 & & 357 & 32 & 14 & .7 & 782 & 8.3 \\
\hline 47 & 28 & .4 & 19 & ......... & ....... & 377 & 278 & 29 & 19 & .8 & ............. & ...... \\
\hline 17 & 6.0 & .5 & 10 & .03 & 354 & ..... & 265 & 17 & 7 & .2 & 499 & 8.4 \\
\hline 26 & 5.0 & .7 & 6.0 & .09 & 326 & & 201 & 0 & 18 & .6 & 448 & 8.4 \\
\hline 19 & 5.0 & .9 & 2.0 & .04 & 278 & |a... & 187 & 2 & 13 & .4 & 388 & 8.5 \\
\hline 26 & 6 & .9 & 14 & ........ & ..... & 242 & 186 & 4 & 19 & .7 & ........... & $\ldots$ \\
\hline
\end{tabular}


Ground water in the area is predominantly of the calcium magnesium bicarbonate type. In the extreme western part of the area, however, calcium and magnesium sulfates constitute the major part of the dissolved constituents. The presence of high sulfate concentrations in the Quaternary deposits in the western part of the area may be due in part to the influence of the underlying shale.

Throughout the report area both municipal and rural water supplies are obtained from underground sources. The suitability of the water for human consumption may be evaluated by comparing the chemical quality with the U. S. Public Health Service (1946) standards for drinking water. These standards, which are mandatory only for water used in interstate traffic but which have been accepted by the American Water Works Association as the criteria for public supplies, are given below.

Drinking-water standards of the $U$. S. Public IIealth Service and maximum and average concentrations of selected constituents in 22 samples of ground water

[In parts per million]

\begin{tabular}{|c|c|c|c|c|}
\hline Constituent & $\begin{array}{l}\text { U. S. Public } \\
\text { Health } \\
\text { Service } \\
\text { maximum } \\
\text { limit }\end{array}$ & $\begin{array}{c}\text { Maximum } \\
\text { in } \\
\text { samples }\end{array}$ & \begin{tabular}{|c|}
$\begin{array}{l}\text { Number } \\
\text { of } \\
\text { samples } \\
\text { exceeding } \\
\text { limit }\end{array}$ \\
\end{tabular} & $\begin{array}{l}\text { Average } \\
\text { in } \\
\text { samples }\end{array}$ \\
\hline 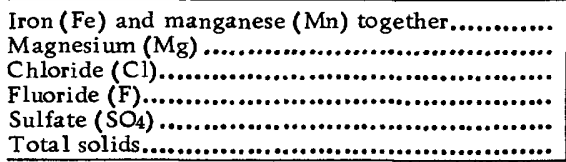 & $\begin{array}{c}0.3 \\
125 \\
250 \\
1.5 \\
250 \\
\mathrm{~b}_{500} \\
\end{array}$ & $\begin{array}{r}a_{6.5} \\
85 \\
55 \\
2.0 \\
1,030 \\
c_{1}, 850 \\
\end{array}$ & $\begin{array}{r}a_{4} \\
0 \\
0 \\
2 \\
2 \\
\mathrm{c}_{11} \\
\end{array}$ & $\begin{array}{l}a_{1.4} \\
29 \\
23 \\
154^{.8} \\
\mathrm{c}_{681} \\
\end{array}$ \\
\hline
\end{tabular}

aIron and manganese together determined for 3 samples only; iron alone, for 6 samples; manganese alone, 7 samples.

$b_{1}, 000$ ppm permitted if water of better quality is not available.

cDissolved solids, residue on evaporation at $180^{\circ} \mathrm{C}, 16$ samples only.

High concentrations of iron and manganese are objectionable in water because these metals stain porcelain, linens, and other products. In addition, iron may cause turbidity in water and introduce an unpleasant taste. Of the 3 samples for which the concentration of both iron and manganese was determined, 1 contained more than the standard limit; of the 6 samples for which iron alone was determined, 3 contained more than the standard limit. Two samples, from wells $1-40-26$ aa and $1-41-27 \mathrm{~cd}$, contained 6.5 and $4.0 \mathrm{ppm}$ (parts per million) total iron, respectively.

Magnesium is similar to calcium in that it produces hardness in water. Water containing high concentrations of magnesium salts has a pronounced physiological effect when drunk by persons 
who normally consume water of low mineral content. However, a tole rance to relativelyhigh concentrations of magnesium salts can be acquired in a moderately short time.

Sodium chloride in solution in amounts exceeding about $500 \mathrm{ppm}$ gives a salty taste to water. Also, appreciable amounts of chloride in water are undesirable in many industrial processes. The maximum concentration of chloride in the samples collected in this area was $55 \mathrm{ppm}$, and the average was $23 \mathrm{ppm}$.

A fluoride concentration of about $1 \mathrm{ppm}$ in drinking water lessens the incidence of dental caries in the permanent teeth of children, but a concentration in excess of about $1.5 \mathrm{ppm}$ may cause the dental defect known as mottled enamel (Dean, 1938).

Sulfate is of little significance in water used for drinking except that amounts in excess of the recommended standard of $250 \mathrm{ppm}$ may produce an objectionable taste or physiological effect. High concentrations of calcium sulfate are particularly objectionable in water used in steam boilers because this constituent is likely to form a boiler scale that is difficult to remove.

Water having a dissolved-solids content of less than $500 \mathrm{ppm}$ is satisfactory for domestic andmost industrial uses, but water containing more than $1,000 \mathrm{ppm}$ maycause physiological disturbances except to those accustomed to drinking water of such mineralization.

Recent studies (Maxcy, 1950) show that a high concentration of nitrates in drinking water may be a contributing factor in the development of cyanosis in infants. Only the sample from well 3-31-17ad contained more than the generally accepted limit for supplies used for preparing feeding formulas.

Hardness caused by the calcium and magnesium equivalent to the bicarbonate in a water is called carbonate hardness and the remainder noncarbonate hardness. Excessive hardness is recognized by the quantity of soap required to produce a lather and by the formation of an insoluble curd in all washing processes in which soap is used. It is particularly objectionable in many industrial operations that require large volumes of water. Water containing more than 180 ppm of hardness is generally considered very hard; all samples analyzed contained hardness in excess of 180 ppm.

The suitability of the water for irrigation may be evaluated by the method of the U. S. Salinity Laboratory Staff (1954). (See fig. 81 and interpretation on p. 627.) Among the criteria for classifying irrigation waters are total dissolved material (salinity) and the relation of sodium concentration to total cations and sodium 


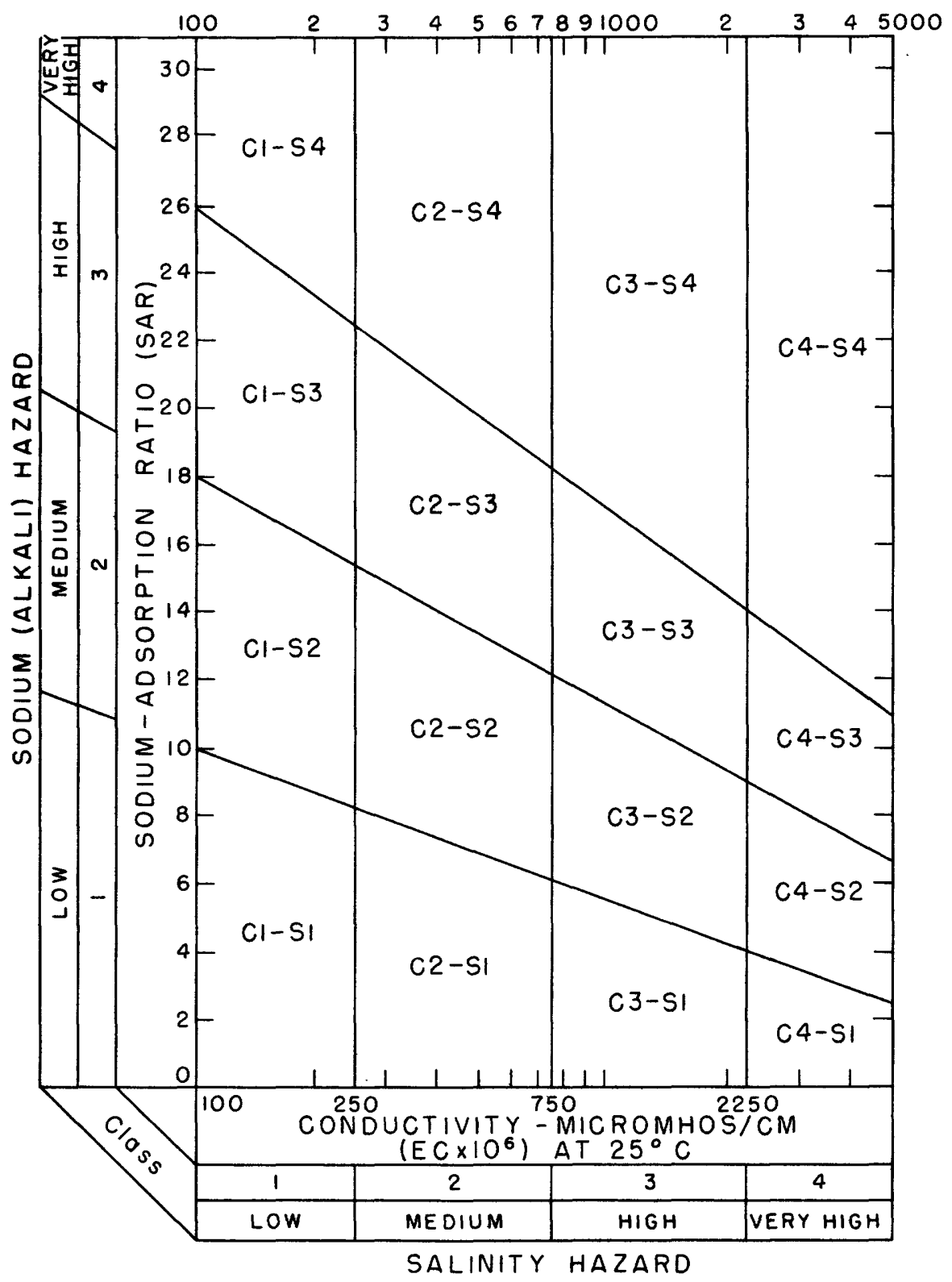

Figure 81. Classification of irrigation water (After U. S. Salinity Laboratory Staff, 1954) 


\section{CLASGIFICATION OF IRRIGATION WATER}

[After U. S. Salinity Laboratory Staff, 1954]

\section{SALINITY HAZARD}

LOW-SALINITY WATER $\left(C_{1}\right)$ can be used for irrigation with most crops on most soils with little likelihood that soil salinity will develo.p. Some leaching is required, but this occurs under normal irrigation practices except in soils of extremely low permeability.

MEDIUM-SALINITY WATER $\left(C_{2}\right)$ can be used if a moderate a mount of leaching occurs. Plants with moderate salt tolerance can be grown in most cases without special practices for salinity control.

HIGH-SALINITY WATER $\left(\mathrm{C}_{3}\right)$ cannot be used on soils wi th restricted drainage. Even with adequate drainage, special management for salinity control may be required and plants with good salt tolerance should be selected.

VERY HIGH SALINITY WATER $\left(C_{4}\right)$ is not suitable for irrigation under ordinary conditions, but may be used occasionally under very special circumstances. The soils mustbe permeable, drainage must be adequate, irrigation water must be applied in excess to provide considerable leaching, and very salt-tolerant crops should be selected.

\section{SODIUM HAZARD}

The classification of irrigation waters with respect to SAR is based primarily on the effect of exchangeable sodium on the physical condition of the soil. Sodium-sensitive plants may, however, suffer injury as a result of sodium accumulation in plant tissues when exchangeable sodium values are lower than those effective in causing deterioration of the physical condition of the soil.

LOW-SODIUM WATER $\left(S_{1}\right)$ can be used for irrigation on almost all soils with little danger of the development of harmful levels of exchangeable sodium. However, sodium-sensitive crops such as stone-fruit trees and avocados may accumulate injurious concentrations of sodium.

MEDIUM-SODIUM WATER $\left(S_{2}\right)$ will present an appreciable sodium hazard in fine-textured soils having high cation-exchange-capacity, especially under low-leaching conditions, unless gypsum is present in the soil. This water may be used on coarse-textured or organic soils with good permeability.

HIGH-SODIUM WATER $\left(\mathrm{S}_{3}\right)$ may produce harmful levels of exchangeable sodium in most soils and will require special soil management-good drainage, high leaching, and organic matter additions. Gypsiferous soils may not develop harmful levels of exchangeable sodium from such waters. Chemical amendments may be required for replacement of exchangeable sodium, except that amendments may not be feasible with waters of very high salinity.

VERY HIGH SODIUM WATER $\left(\mathrm{S}_{4}\right)$ is generally unsatisfactory for irrigation purposes except at low and perhaps medium salinity, where the solution of calcium from the soil or use of gypsum or other amendments may make the use of these waters feasible. 
adsorption by the soil (sodium-adsorption ratio). Specific conductance is a measure of salinity, and sodium-adsorption ratio is defined as $\mathrm{Na} / \sqrt{(\mathrm{Ca}+\mathrm{Mg}) / 2}$ (concentrations in equivalents per million). The classification is based on use of water under average conditions with respect to soil texture, infiltration rate, drainage, quantity applied, salt tolerance of crops, and climate. The water in the report area was classified as having a low sodium hazard and a medium to high salinity hazard. However, good drainage minimizes the adverse effects resulting from the continued application of highly saline water.

Although small quantities of boron are essential to the growth of most plants, concentrations of boron exceeding about $0.3 \mathrm{ppm}$ may be harmful in water used for the irrigation of boron-sensitive plants. Of the 10 samples for which the boron content was determined, none contained more than $0.25 \mathrm{ppm}$.

\section{WATER-LEVEL MEASUREMENTS}

All water-level measurements in observation wells made during the course of this investigation are given in appendix $\mathrm{A}$.

\section{WELL RECORDS}

Records of the wells visited in the valleys of the Republican and Frenchman Rivers are given in appendix B. The wells are listed alphabetically by counties and by coordinate order in each county.

\section{CONCLUSIONS}

The principal accomplishments of the investigation were the establishment of an extensive network of observation wells and the periodic measurement of the water level in the wells. The observation of water-level fluctuations should be continued so that a rising or declining water level can be detected well in advance of possible drastic results, and efforts to alleviate the condition can be made. The measurement of water levels to date has made pos sible the delineation of certain areas in which ground-water problems exist. In some of these areas the installation of additional observation wells would be an aid to the study of the problems.

If the maximum potential use of the ground-water resources of the Republican River valley is to be realized, detailed hydrologic studies of the valley and adjacent uplands should be made. The making of such studies would require (1) the preparation of maps 
showing the contour of the water table in the areas between the Platte and Republican Rivers and between Beaver Creek and the Republican River, (2) the determination of the hydrologic properties of the water-bearing materials, (3) the evaluation of all sources of recharge to and discharge from the aquifer, (4) the making of quantitative studies of the relationship between streamflow and ground water in the valleys of the Republican River and its tributaries, and (5) the collection and evaluation of additional data on the chemical quality of the water.

\section{LITERATURE CITED}

Condra, G. E., 1907, Geology and water resources of the Republican River valley and adjacent areas, Nebraska: U. S. Geol. Survey Water-Supply Paper 216.

Condra, G. E., and Reed, E. C., 1943, The geological section of Nebraska: Nebr. Geol. Survey Bull. 14.

Condra, G. E., Reed, E. C., and Gordon, E. D., 1950, Correlation of the Pleistocene deposits of Nebraska: Nebr. Geol. Survey Bull. 15A.

Dean, H. T., 1938, Endemic fluorosis and its relation to dental caries: Public Heal th Repts., v. 53, p. 1445-1452.

Elias, M. K., 1931, The geology of Wallace County, Kans.: Kans. Geol. Survey Bull. 18.

Fenneman, N. M., 1931, Physiography of western United States: New York, McGraw-Hill Book Co., Inc.

Lugn, A. L., and Wenzel, L. K., 1938, Geology and ground-water resources of southcentral Nebraska, with special reference to the Platte River valley between Chapman and Gothenburg: U. S. Geol Survey Water-Supply Paper 779.

Maxcy, K. F., 1950, Report on the relation of nitrate concentrations in well waters to the occurrence of methemoglobinemia: Natl. Research Council Bull., Sanitary Engineer, p. 265, app. D.

Meinzer, O. E., 1923a, Occurrence of ground water in the United States, with a discussion of principles: U. S. Geol. Survey Water-Supply Paper 489.

United States Public Health Service, 1946, Drinking water standards: Public Health Repts., v. 61, no. 11 , p. 371-384.

United States Salinity Laboratory Staff, 1954, Diagnosis and improvement of saline and alkali soils: U. S. Dept. Agriculture. Agriculture Handb. 60.

Waite, H. A., Reed, E. C., and Jones, D. S., 1946, Ground water in the Republican River basin in Nebraska: Nebr. Water Res. Survey Water-Supply Paper 1.

Waite, H. A., and others, 1948, Progress report on the ground-water hydrology of the Republican and Frenchman River valleys, with a section on the chemical quality of the ground water, by H. A., Swenson: U. S. Geol. Survey Circ. 19. 

A PPENDIX A 
Water-level measurements in wells, in feet below land-surface datum, with recorder chart readings of lowest daily water levels in 1950

[An asterisk $\left({ }^{*}\right)$ indicates measurement by the U. S. Bureau of Reclamation; two asterisks $\left({ }^{*}\right.$ ) indicate measurement by the State of Nebraska]

\begin{tabular}{c|l||l|l|l|l}
\hline Date & $\begin{array}{l}\text { Water } \\
\text { level }\end{array}$ & Date & $\begin{array}{l}\text { Water } \\
\text { level }\end{array}$ & Date & $\begin{array}{l}\text { Water } \\
\text { level }\end{array}$ \\
\hline
\end{tabular}

\section{CHASE COUNTY}

$5-36-7 b a$

\begin{tabular}{l|r|l|l|l||l|l}
\hline Feb. 4, 1948 & 15.70 & July 19, 1949* & 15.87 & Apr. 4, 1950 & 15.85 \\
Apr. 12 & 15.98 & Aug. 4 & 16.20 & June 1 & 15.91 \\
June 11 & 16.25 & Oct. 6 & 16.00 & July 11 & 16.29 \\
Aug. 5 & 16.28 & Nov. 17 & 15.95 & Aug. 11 & 16.18 \\
Oct. 6 & 16.24 & Dec. 20 & 15.95 & Sept. 19 & 16.11 \\
Dec. 10 & 15.78 & Jan. 19, 1950 & 15.80 & Oct. 16 & 16.16 \\
Feb. 8, 1949 & 15.69 & Mar. 1 & 15.81 & Dec. 7 & 16.86 \\
June 9 & 14.93 & & & & \\
\hline
\end{tabular}

$5-36-10 b b$

\begin{tabular}{l|l|l|l||l|l}
\hline Mar. 23, 1949* & 6.53 & Oct. 6, 1949 & 4.92 & June 1, 1950 & 4.67 \\
Apr. 22* & 4.23 & Nov. 17 & 4.70 & July 11 & 5.18 \\
June 9 & 3.33 & Dec. 20 & 4.61 & Aug. 11 & 5.04 \\
July 19* & 4.96 & Jan. 19, 1950 & 3.35 & Sept. 19 & 4.82 \\
Aug. 4 & 5.27 & Mar. 1 & 4.47 & Oct. 16 & 4.87 \\
Aug. 26* & 5.33 & Apr. 4 & 4.40 & Dec. 7 & 5.66 \\
\hline
\end{tabular}

$5-37-2 d c$

\begin{tabular}{l|l|l|l||l|l}
\hline Mar. 23, 1949* & 6.53 & Oct. 6,1949 & 7.05 & June 1, 1950 & 6.91 \\
Apr. 22* & 6.13 & Nov. 17 & 6.86 & July 11 & 7.61 \\
June 9 & 5.73 & Dec. 20 & 6.85 & Aug. 11 & 7.49 \\
July 19* & 5.40 & Jan. 19, 1950 & 6.81 & Sept. 19 & 7.22 \\
Aug. 4 & 7.10 & Mar. 1 & 6.80 & Oct. 16 & 7.23 \\
Aug. 26* & 7.46 & Apr. 4 & 6.78 & Dec. 7 & 7.93 \\
\hline
\end{tabular}

$5-37-3 c c$

\begin{tabular}{|c|c|c|c|c|c|}
\hline $\begin{array}{lc}\text { Feb. } & 10,1949^{*} \\
\text { Mar. } & 23^{*} \\
\text { Apr. } & 22 \\
\text { June } & 9 \\
\text { July } & 19^{*} \\
\text { Aug. } & 4 \\
\text { Aug. } & 26^{*}\end{array}$ & $\begin{array}{l}25.40 \\
25.48 \\
25.19 \\
24.88 \\
24.90 \\
25.00 \\
25.25\end{array}$ & 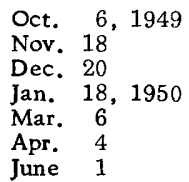 & $\begin{array}{l}24.34 \\
23.85 \\
24.26 \\
23.70 \\
23.54 \\
23.69 \\
23.62\end{array}$ & $\begin{array}{lr}\text { July } 11,1950 \\
\text { Aug. } 11 \\
\text { Sept. } 19 \\
\text { Oct. } 16 \\
\text { Dec. } 7 \\
\text { Dec. } 28\end{array}$ & $\begin{array}{l}23.86 \\
23.74 \\
23.82 \\
23.78 \\
22.11 \\
20.72\end{array}$ \\
\hline
\end{tabular}

$5-37-3 c d$

\begin{tabular}{l|l|l|l||l|l}
\hline Apr. 22, 1949* & 5.52 & Nov. 18, 1949 & 5.81 & July 11, 1950 & 6.39 \\
June 9 & 5.10 & Dec. 20 & 5.77 & Aug. 11 & 6.30 \\
July 19* & 5.88 & Jan. 18, 1950 & 5.80 & Sept. 19 & 6.14 \\
Aug. 4 & 6.02 & Mar. 6 & 5.79 & Oct. 16 & 6.23 \\
Aug. $26^{*}$ & 6.30 & Apr. 6 & 5.72 & Dec. 7 & 6.91 \\
Oct. 6 & 6.00 & June 1 & 5.96 & Dec. 28 & 6.70 \\
\hline
\end{tabular}

$5-37-4$ dac

\begin{tabular}{ll|l|l|l||l|l}
\hline Dec. 7,1950 & 77.85 & Dec. 28,1950 & 74.20 & & \\
\hline
\end{tabular}


Water-level measurements in wells, in feet below land-surface datum, with recorder chart readings of lowest daily water levels in 1950-Continued

\begin{tabular}{c|c||c|c||c|c}
\hline Date & $\begin{array}{l}\text { Water } \\
\text { level }\end{array}$ & Date & $\begin{array}{l}\text { Water } \\
\text { level }\end{array}$ & Date & $\begin{array}{l}\text { Water } \\
\text { level }\end{array}$ \\
\hline
\end{tabular}

\section{CHASE COUNTY-Continued}

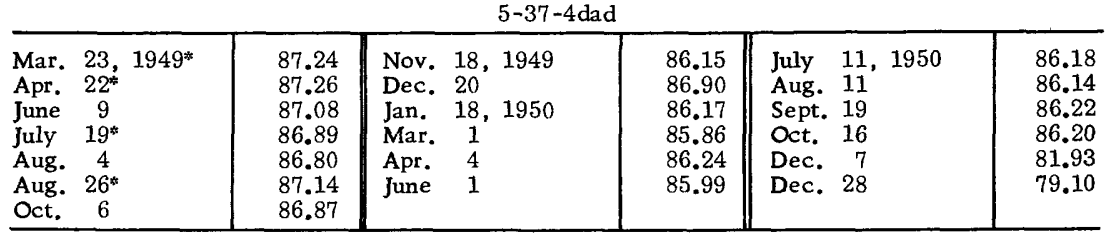

$5-37-4$ dd

\begin{tabular}{l|l||l|l||l|l}
\hline Dec. 7,1950 & 67.36 & Dec. 28, 1950 & 62.71 & & \\
\hline
\end{tabular}

$5-37-5$ dd

\begin{tabular}{l|l||l|l||l|l|}
\hline Oct. 16,1950 & 145.31 & Dec. 7,1950 & 140.81 & Dec. 28, 1950 & 137.62 \\
\hline
\end{tabular}

$5-37-9 a d b 1$

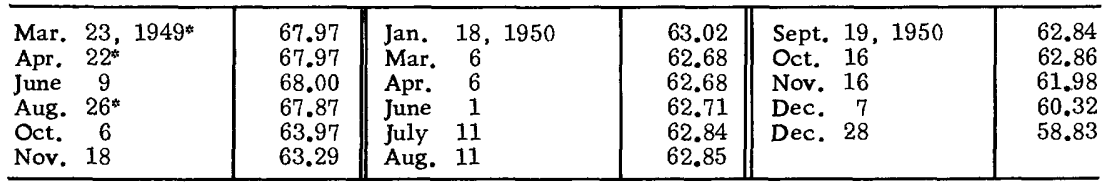

$5-37-9 a d b 2$

\begin{tabular}{|c|c|c|c|c|c|}
\hline $\begin{array}{lc}\text { Apr. } & 22,1949^{*} \\
\text { June } & 9 \\
\text { July } & 19^{*} \\
\text { Aug. } & 4 \\
\text { Aug. } & 26^{*} \\
\text { Oct. } & 6 \\
\text { Nov. } & 18\end{array}$ & $\begin{array}{l}84.74 \\
83.95 \\
83.94 \\
83.90 \\
84.15 \\
79.85 \\
78.95\end{array}$ & $\begin{array}{lrl}\text { Dec. } & 20,1949 \\
\text { Jan. } & 18,1950 \\
\text { Mar. } & 6 & \\
\text { Apr. } & 6 & \\
\text { June } & 1 & \\
\text { July } & 11 & \end{array}$ & $\begin{array}{l}79.13 \\
78.50 \\
78.24 \\
78.24 \\
78.18 \\
78.35\end{array}$ & $\begin{array}{l}\text { Aug. } 11,1950 \\
\text { Sept. } 19 \\
\text { Oct. } 16 \\
\text { Nov. } 16 \\
\text { Dec. } 7 \\
\text { Dec. } 28\end{array}$ & $\begin{array}{l}78.07 \\
78.35 \\
78.24 \\
77.49 \\
75.88 \\
74.20\end{array}$ \\
\hline
\end{tabular}

5-37-9adb3

\begin{tabular}{|c|c|c|c|c|c|}
\hline 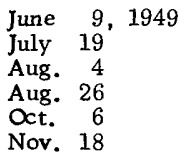 & $\begin{array}{l}98.45 \\
97.83 \\
98.42 \\
97.68 \\
95.00 \\
93.85\end{array}$ & $\begin{array}{lrl}\text { Dec. } & 20,1949 \\
\text { Jan. } & 18,1950 \\
\text { Mar. } & 6 & \\
\text { Apr. } & 6 & \\
\text { June } & 1 & \\
\text { July } & 11 & \end{array}$ & $\begin{array}{l}93.57 \\
93.37 \\
93.10 \\
93.08 \\
93.04 \\
93.16\end{array}$ & $\begin{array}{l}\text { Aug. } 11,1950 \\
\text { Sept. } 19 \\
\text { Oct. } 16 \\
\text { Nov. } 16 \\
\text { Dec. } 7 \\
\text { Dec. } 28\end{array}$ & $\begin{array}{l}93.09 \\
93.12 \\
93.09 \\
92.25 \\
90.43 \\
88.75\end{array}$ \\
\hline
\end{tabular}

5-37-10ba

\begin{tabular}{l|l||l|l||l|l}
\hline Apr. 22, 1949* & 6.84 & Nov. 18, 1949 & 6.99 & July 11, 1950 & 7.67 \\
June 9 & 5.37 & Dec. 20 & 6.90 & Aug. 11 & 7.60 \\
July 19* & 7.06 & Jan. 18, 1950 & 7.07 & Sept. 19 & 7.32 \\
Aug. 4 & 7.57 & Mar. 6 & 7.10 & Oct. 16 & 7.51 \\
Aug. 26* & 7.52 & Apr. 6 & 6.99 & Dec. 7 & 8.24 \\
Oct. 6 & 7.13 & June 1 & 7.23 & Dec. 28 & 8.19 \\
\hline
\end{tabular}


Water-level measurements in wells, in feet below land-surface datum, with recorder chart readings of lowest daily water levels in 1950-Continued

\begin{tabular}{l|l||l|l||l|l}
\hline Date & $\begin{array}{l}\text { Water } \\
\text { level }\end{array}$ & Date & $\begin{array}{l}\text { Water } \\
\text { level }\end{array}$ & $\begin{array}{l}\text { Water } \\
\text { level }\end{array}$ \\
\hline
\end{tabular}

\section{CHASE COUNTY-Continued}

$5-37-10 \mathrm{bbb}$

\begin{tabular}{|c|c|c|c|c|c|c|c|c|}
\hline $\begin{array}{l}\text { Feb. } \\
\text { Mar. } \\
\text { Apr. } \\
\text { June } \\
\text { July } \\
\text { Aug. } \\
\text { Aug. }\end{array}$ & $\begin{array}{l}10,1949 * \\
23^{*} \\
22^{*} \\
9 \\
19 * \\
4 \\
26 *\end{array}$ & $\begin{array}{l}7.30 \\
7.26 \\
6.80 \\
6.01 \\
6.39 \\
6.68 \\
6.96\end{array}$ & $\begin{array}{l}\text { Oct. } \\
\text { Nov. } \\
\text { Dec. } \\
\text { Jan. } \\
\text { Mar. } \\
\text { Apr. } \\
\text { June }\end{array}$ & $\begin{array}{cc}6, & 1949 \\
18 & \\
20 & \\
18, & 1950 \\
6 & \\
4 & \\
1 & \end{array}$ & $\begin{array}{l}4.90 \\
4.76 \\
4.67 \\
4.68 \\
4.55 \\
4.60 \\
4.57\end{array}$ & $\begin{array}{l}\text { July } \\
\text { Aug. } \\
\text { Sept. } \\
\text { Oct. } \\
\text { Dec. } \\
\text { Dec. }\end{array}$ & $\begin{array}{rr}11, & 1950 \\
11 & \\
19 & \\
16 & \\
7 & \\
28 & \end{array}$ & $\begin{array}{l}4.99 \\
5.01 \\
4.77 \\
4.84 \\
4.54 \\
4.09\end{array}$ \\
\hline
\end{tabular}

$5-37-10 b b c$

\begin{tabular}{|c|c|c|c|c|c|c|c|}
\hline $\begin{array}{l}\text { Feb. } \\
\text { Mar. } \\
\text { Apr. } \\
\text { June } \\
\text { July } \\
\text { Aug. } \\
\text { Aug. }\end{array}$ & $\begin{array}{l}10,1949 * \\
23^{*} \\
22^{*} \\
9 \\
19^{*} \\
4 \\
26^{*}\end{array}$ & $\begin{array}{l}14.48 \\
14.59 \\
14.31 \\
13.60 \\
13.86 \\
14.16 \\
14.29\end{array}$ & $\begin{array}{l}\text { Oct. } \\
\text { Nov. } \\
\text { Dec. } \\
\text { Jan. } \\
\text { Mar. } \\
\text { Apr. } \\
\text { June }\end{array}$ & $\begin{array}{cc}6, & 1949 \\
18 & \\
20 & \\
18, & 1950 \\
6 & \\
4 & \\
1 & \end{array}$ & $\begin{array}{l}11.28 \\
11.06 \\
10.95 \\
10.88 \\
10.78 \\
10.85 \\
10.85\end{array}$ & $\begin{array}{lr}\text { July } & 11,1950 \\
\text { Aug. } & 11 \\
\text { Sept. } & 19 \\
\text { Oct. } & 16 \\
\text { Dec. } & 7 \\
\text { Dec. } & 28\end{array}$ & $\begin{array}{l}11.14 \\
11.14 \\
11.01 \\
11.05 \\
11.02 \\
10.64\end{array}$ \\
\hline
\end{tabular}

$5-37-10 b c$

\begin{tabular}{|c|c|c|c|c|c|}
\hline $\begin{array}{lc}\text { Mar. } & 23, \\
\text { Apr. } & 22^{*} \\
\text { June } & 9 \\
\text { July } & 19 * \\
\text { Aug. } & 4 \\
\text { Aug. } & 26^{*} \\
\text { Oct. } & 6\end{array}$ & $\begin{array}{l}19.21 \\
18.94 \\
18.36 \\
18.44 \\
18.59 \\
18.78 \\
15.81\end{array}$ & $\begin{array}{lcl}\text { Nov. } & 18, & 1949 \\
\text { Dec. } & 20 & \\
\text { Jan. } & 18, & 1950 \\
\text { Mar. } & 6 & \\
\text { Apr. } & 6 & \\
\text { June } & 1 & \end{array}$ & $\begin{array}{l}15.20 \\
14.99 \\
14.85 \\
14.69 \\
14.73 \\
14.72\end{array}$ & 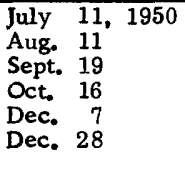 & $\begin{array}{l}14.92 \\
14.88 \\
14.87 \\
14.84 \\
14.55 \\
14.02\end{array}$ \\
\hline
\end{tabular}

$5-38-1$ bd

\begin{tabular}{l|l||l|l||l|l|l}
\hline Mar. 24, 1950 & 23.82 & Nov. 16, 1950 & 23.91 & Dec. 7, 1950 & 23.66 \\
Oct. 16 & 24.18 & & & & \\
\hline
\end{tabular}

$5-38-1 d a$

\begin{tabular}{l|l|l||l|l||l|l|}
\hline Mar. 24, 1950 & 6.67 & Aug. 11, 1950 & 6.95 & Nov. 16, 1950 & 6.20 \\
June 1 & 6.60 & Sept. 19 & 6.88 & Dec. 7 & 6.61 \\
\hline July 11 & 7.02 & Oct. 16 & 6.82 & & \\
\hline
\end{tabular}

$5-38-2 a c$

\begin{tabular}{|c|c|c|c|c|c|}
\hline $\begin{array}{l}\text { Mar. } 24,1950 \\
\text { June } \\
\text { July } 11\end{array}$ & $\begin{array}{l}12.96 \\
12.85 \\
13.20\end{array}$ & $\begin{array}{l}\text { Aug. } 11,1950 \\
\text { Sept. } 19\end{array}$ & $\begin{array}{l}13.11 \\
13.00\end{array}$ & $\begin{array}{ll}\text { Oct. } & 16,1950 \\
\text { Dec. } & 7\end{array}$ & $\begin{array}{l}12.97 \\
12.83\end{array}$ \\
\hline
\end{tabular}

$5-38-3 a d$

\begin{tabular}{l|r||l|l||l|l}
\hline Apr. 22, 1949* & 6.26 & Nov. 18, 1949 & 6.79 & July 11, 1950 & 7.03 \\
June 9 & 5.92 & Dec. 20 & 6.55 & Aug. 11 & 6.75 \\
July 19* & 6.28 & Jan. 19, 1950 & 6.46 & Sept. 19 & 6.83 \\
Aug. 4 & 6.36 & Mar. 1 & 6.36 & Oct. 16 & 6.81 \\
Aug. $26^{*}$ & 7.03 & Apr. 6 & 6.33 & Dec. 7 & 6.57 \\
Oct. 6 & 6.85 & June 1 & 6.58 & & \\
\hline
\end{tabular}

5-38-4aa

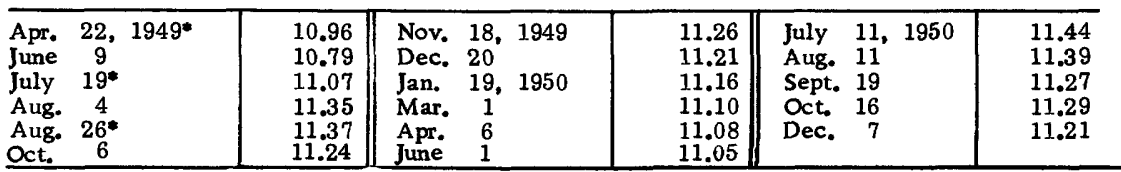


GROUND-WATER GEOLOGY, REPUBLICAN AND FRENCHMAN VALLEYS, NEBR, 635

Water-level measurements in wells, in feet below land-surface datum, with tecorder chart readings of lowest daily water levels in 1950-Continued

\begin{tabular}{c|c||c|c||c|c}
\hline Date & $\begin{array}{l}\text { Water- } \\
\text { level }\end{array}$ & Date & $\begin{array}{l}\text { Water } \\
\text { level }\end{array}$ & Dąe & $\begin{array}{l}\text { Water } \\
\text { level }\end{array}$ \\
\hline
\end{tabular}

CHASE COUNTY-Continued

$5-38-4 a d$

\begin{tabular}{|c|c|c|c|c|c|}
\hline $\begin{array}{lcl}\text { Apr. } & 22, & 1949^{*} \\
\text { June } & 9 & \\
\text { July } & 19^{*} & \\
\text { Aug. } & 4 \\
\text { Aug. } & 26^{*} \\
\text { Oct. } & 6\end{array}$ & $\begin{array}{l}4.51 \\
4.48 \\
5.28 \\
5.37 \\
5.44 \\
5.15\end{array}$ & $\begin{array}{lcl}\text { Nov. } & 18, & 1949 \\
\text { Dec. } & 20 & \\
\text { Jan. } & 19, & 1950 \\
\text { Mar. } & 1 & \\
\text { Apr. } & 6 & \\
\text { June } & 1 & \end{array}$ & $\begin{array}{l}5.05 \\
4.97 \\
5.01 \\
4.91 \\
4.84 \\
4.96\end{array}$ & $\begin{array}{lr}\text { July } & 11,1950 \\
\text { Aug. } & 11 \\
\text { Sept. } & 19 \\
\text { Oct. } & 16 \\
\text { Dec. } & 7\end{array}$ & $\begin{array}{l}5.33 \\
5.14 \\
4.98 \\
5.09 \\
4.88\end{array}$ \\
\hline
\end{tabular}

$6-37-32 b a$

\begin{tabular}{|c|c|c|c|c|c|}
\hline Mar. 24, 1950 & 71.61 & Dec. 7,1950 & 71.98 & Dec. 28,1950 & 71.78 \\
\hline \multicolumn{6}{|c|}{$6-37-32 d c$} \\
\hline $\begin{array}{ll}\text { Oct. } & 7,1948^{*} \\
\text { Dec. } & 8 *\end{array}$ & $\begin{array}{l}19.65 \\
19.34\end{array}$ & $\begin{array}{l}\text { Feb. } 10,1949^{*} \\
\text { Mar. } 23^{*}\end{array}$ & $\begin{array}{l}18.95 \\
18.90\end{array}$ & $\begin{array}{l}\text { Aug. } 26,1949^{*} \\
\text { Mar. } 6,1950\end{array}$ & $\begin{array}{l}19.20 \\
18.73\end{array}$ \\
\hline
\end{tabular}

\begin{tabular}{|c|c|c|c|c|c|c|c|c|c|c|}
\hline \multirow{2}{*}{ Day } & \multicolumn{10}{|c|}{ Month } \\
\hline & Mar. & Apr. & May & June & July & Aug. & Sept. & Oct. & Nov. & Dec. \\
\hline $\begin{array}{r}1 \\
2 \\
3 \\
4 \\
5 \\
6 \\
7 \\
8 \\
9 \\
10 \\
11 \\
12 \\
13 \\
14 \\
15 \\
16 \\
17 \\
18 \\
19 \\
20 \\
21 \\
22 \\
23 \\
24 \\
25 \\
26 \\
27 \\
28 \\
29 \\
30 \\
31\end{array}$ & $\ldots \ldots \ldots \ldots \ldots . . \ldots$ & $\begin{array}{l}18.87 \\
18.84 \\
18.81 \\
18.78 \\
18.76 \\
18.72 \\
18.75 \\
18.75 \\
18.74 \\
18.83 \\
18.83 \\
18.83 \\
18.83 \\
18.84 \\
18.85 \\
18.85 \\
18.83 \\
18.87 \\
18.87 \\
18.87 \\
18.83 \\
18.83 \\
18.84 \\
18.89 \\
18.89 \\
18.90 \\
18.90 \\
18.90 \\
18.92 \\
18.92 \\
\ldots . . . . .\end{array}$ & $\begin{array}{l}18.89 \\
18.86 \\
18.88 \\
18.86 \\
18.84 \\
18.80 \\
18.80 \\
18.79 \\
18.80 \\
18.81 \\
18.80 \\
18.84 \\
18.83 \\
18.82 \\
18.82 \\
18.85 \\
18.85 \\
18.85 \\
18.85 \\
18.86 \\
18.86 \\
18.86 \\
18.87 \\
18.89 \\
18.91 \\
18.89 \\
18.82 \\
18.83 \\
18.83 \\
18.88 \\
18.88\end{array}$ & \begin{tabular}{|r|}
18.86 \\
18.92 \\
18.92 \\
18.92 \\
18.92 \\
18.93 \\
18.97 \\
18.99 \\
19.02 \\
19.03 \\
19.02 \\
19.02 \\
19.05 \\
19.05 \\
19.07 \\
19.07 \\
19.00 \\
19.00 \\
19.00 \\
18.97 \\
18.97 \\
18.97 \\
19.00 \\
19.01 \\
19.08 \\
19.08 \\
19.07 \\
19.09 \\
19.08 \\
$\ldots \ldots \ldots . .0$ \\
$\ldots \ldots \ldots . .$.
\end{tabular} & 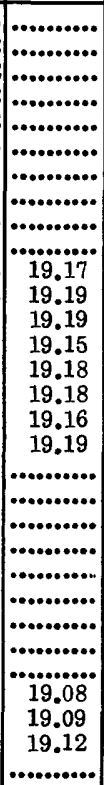 & $\begin{array}{c}\cdots \ldots \ldots \ldots \\
\cdots \ldots \ldots \ldots \ldots \\
\cdots \ldots \ldots \ldots \ldots \\
\cdots \ldots \ldots \ldots \\
19.15 \\
19.16 \\
19.17 \\
19.18 \\
19.18 \\
19.17 \\
19.17 \\
\cdots \ldots \ldots \ldots \\
\cdots \ldots \ldots \ldots \\
\cdots \ldots \ldots \ldots \\
19.19 \\
19.21 \\
19.21 \\
19.19 \\
19.19 \\
19.22 \\
19.24 \\
19.24 \\
19.23 \\
19.23 \\
19.24 \\
19.23 \\
19.22 \\
19.20\end{array}$ & $\begin{array}{r}19.19 \\
19.20 \\
19.21 \\
19.21 \\
19.21 \\
19.21 \\
19.22 \\
19.23 \\
\ldots \ldots \ldots . . . \\
\ldots \ldots . . . \\
19.23 \\
19.24 \\
19.23 \\
19.19 \\
19.18 \\
19.15 \\
19.17 \\
19.17 \\
19.16 \\
19.17 \\
19.16 \\
19.15 \\
19.15 \\
19.14 \\
19.13 \\
19.16 \\
19.15 \\
19.12 \\
19.13 \\
\ldots \ldots . . . .\end{array}$ & $\begin{array}{l}19.14 \\
19.18 \\
19.17 \\
19.15 \\
19.11 \\
19.14 \\
19.15 \\
19.16 \\
19.14 \\
19.15 \\
19.16 \\
19.13 \\
19.13 \\
19.12 \\
19.14 \\
19.17 \\
19.14 \\
19.14 \\
19.16 \\
19.14 \\
19.15 \\
19.16 \\
19.16 \\
19.21 \\
19.20 \\
19.15 \\
19.16 \\
19.08 \\
18.85 \\
18.76 \\
18.78\end{array}$ & $\begin{array}{c}18.84 \\
18.86 \\
18.86 \\
18.82 \\
18.78 \\
18.79 \\
18.75 \\
18.72 \\
18.72 \\
18.67 \\
18.57 \\
18.53 \\
18.48 \\
18.37 \\
18.31 \\
18.29 \\
18.12 \\
18.02 \\
17.92 \\
17.88 \\
17.74 \\
17.64 \\
17.56 \\
17.45 \\
17.30 \\
17.19 \\
17.06 \\
16.92 \\
16.76 \\
16.60 \\
\ldots . . . . . . . ~\end{array}$ & $\begin{array}{l}16.46 \\
16.33 \\
16.22 \\
16.04 \\
15.98 \\
15.83 \\
15.68 \\
15.56 \\
15.40 \\
15.23 \\
15.02 \\
14.87 \\
14.70 \\
14.55 \\
14.40 \\
14.24 \\
14.09 \\
13.92 \\
13.76 \\
13.61 \\
13.47 \\
13.30 \\
13.14 \\
13.00 \\
12.81 \\
12.69 \\
12.53 \\
12.36 \\
12.24 \\
12.10 \\
11.90\end{array}$ \\
\hline
\end{tabular}

\begin{tabular}{|c|c|c|c|c|c|}
\hline Date & $\begin{array}{l}\text { Water } \\
\text { level }\end{array}$ & Date & $\begin{array}{l}\text { Water } \\
\text { level }\end{array}$ & Date & $\begin{array}{l}\text { Water } \\
\text { level }\end{array}$ \\
\hline \multicolumn{6}{|c|}{$7-38-20 \mathrm{dd}$} \\
\hline $\begin{array}{l}\text { Sept. } 24,1934 \\
\text { Nov. } 20\end{array}$ & $\begin{array}{l}68.99 \\
68.94\end{array}$ & $\begin{array}{lrl}\text { Jan. } & 11, & 1935 \\
\text { Mar. } & 9\end{array}$ & $\begin{array}{l}68.95 \\
69.04\end{array}$ & $\begin{array}{ll}\text { Apr. } & 29, \\
\text { June } & 1935\end{array}$ & $\begin{array}{l}69.13 \\
68.98\end{array}$ \\
\hline
\end{tabular}


Water-level measurements in wells, in feet below land-surface datum, with recorder chart readings of lowest daily water levels in 1950-Continued

\begin{tabular}{c|l||l|l|l|l|l|}
\hline Date & $\begin{array}{l}\text { Water } \\
\text { level }\end{array}$ & Date & $\begin{array}{l}\text { Water } \\
\text { level }\end{array}$ & $\begin{array}{l}\text { Water } \\
\text { level }\end{array}$ \\
\hline
\end{tabular}

CHASE COUNTY-Continued

7-38-20dd-Continued

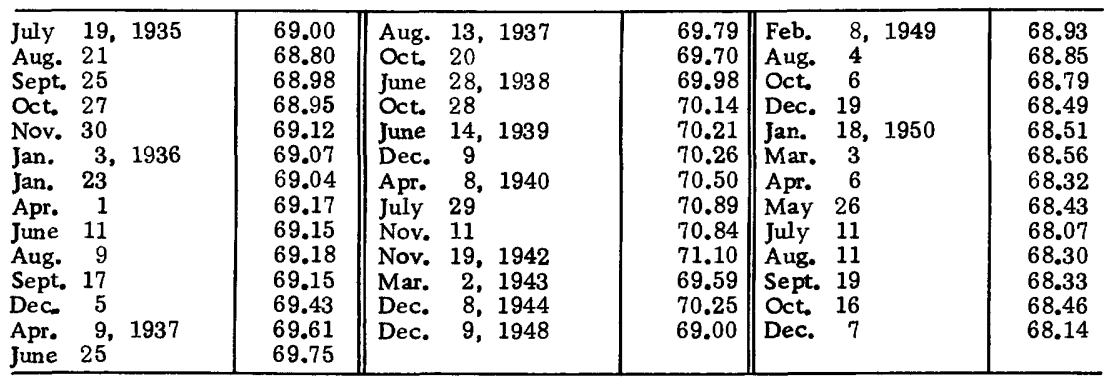

$7-38-28 c c$

\begin{tabular}{|c|c|c|c|c|c|c|c|c|c|c|c|c|}
\hline \multirow{2}{*}{ Day } & \multicolumn{12}{|c|}{ Month } \\
\hline & Jan. & Feb. & Mar. & Apr. & May & June & July & Aug. & Sept. & Oct. & Nov. & Dec. \\
\hline 1 & 75.32 & 75.34 & 75.38 & 75.39 & 75.25 & 75.22 & 75.17 & 75.20 & 75.14 & 75.17 & 75.18 & \\
\hline 2 & 75.30 & 75.37 & 75.38 & 75.28 & 75.17 & 75.27 & 75.17 & 75.18 & 75.13 & 75.24 & 75.23 & \\
\hline 3 & 75.36 & 75.33 & 75.32 & 75.40 & 75.22 & 75.28 & 75.19 & 75.12 & 75.14 & 75.22 & 75.23 & .. \\
\hline 4 & 75.39 & 75.33 & 75.32 & 75.44 & 75.20 & 75.24 & 75.20 & 75.12 & 75.13 & 75.18 & 75.07 & \\
\hline 5 & 75.41 & 75.26 & 75.32 & 75.44 & 75.30 & 75.16 & 75.20 & 75.13 & 75.14 & 75.07 & 75.15 & ...... \\
\hline 6 & 75.42 & 75.28 & 75.24 & 75.33 & 75.30 & 75.14 & 75.18 & 75.14 & 75.11 & 75.15 & 75.17 & \\
\hline 7 & 75.32 & 75.29 & 75.44 & 75.31 & 75.34 & 75.23 & 75.25 & 75.15 & 75.11 & 75.18 & 75.09 & 75.08 \\
\hline 8 & 75.29 & 75.34 & 75.43 & 75.31 & 75.26 & 75.25 & 75.13 & 75.16 & 75.12 & 75.18 & 75.18 & 75.18 \\
\hline 9 & 75.22 & 75.28 & 75.35 & 75.25 & 75.30 & 75.26 & 75.17 & 75.16 & 75.09 & 75.14 & 75.22 & 75.22 \\
\hline 10 & 75.41 & 75.28 & 75.33 & 75.42 & 75.33 & 75.28 & 75.17 & 75.14 & 75.14 & 75.16 & 75.17 & 75.21 \\
\hline 11 & 75.33 & 75.25 & 75.37 & 75.43 & 75.32 & 75.22 & 75.14 & 75.11 & 75.13 & 75.19 & 75.09 & 75.12 \\
\hline 12 & 75.33 & 75.32 & 75.37 & 75.34 & 75.25 & 75.13 & 75.22 & 75.12 & 75.12 & 75.16 & 75.13 & 75.09 \\
\hline 13 & 75.33 & 75.33 & 75.35 & 75.35 & 75.24 & 75.17 & 75.22 & 75.12 & 75.15 & 75.12 & 75.12 & 75.10 \\
\hline 14 & 75.24 & 75.29 & 75.31 & 75.30 & 75.20 & 75.21 & 75.10 & 75.11 & 75.13 & 75.15 & 75.08 & 75.15 \\
\hline 15 & 75.40 & 75.31 & 75.35 & 75.28 & 75.22 & 75.26 & 75.13 & 75.12 & 75.12 & 75.09 & 75.24 & 75.15 \\
\hline 16 & 75.33 & 75.29 & 75.33 & 75.29 & 75.24 & 75.24 & 75.17 & 75.15 & 75.13 & 75.18 & 75.23 & 75.16 \\
\hline 17 & 75.33 & 75.33 & 75.28 & 75.27 & 75.26 & 75.20 & 75.20 & 75.20 & 75.13 & 75.14 & 75.08 & 75.15 \\
\hline 18 & 75.40 & 75.35 & 75.36 & 75.34 & 75.19 & 75.22 & 75.15 & 75.16 & 75.13 & 75.14 & 75.03 & 75.13 \\
\hline 19 & 75.45 & 75.28 & 75.34 & 75.35 & 75.28 & 75.22 & 75.16 & 75.18 & 75.13 & 75.19 & 75.24 & 75.14 \\
\hline 20 & 75.36 & 75.21 & 75.31 & 75.32 & 75.25 & 75.17 & 75.19 & 75.14 & 75.14 & 75.13 & 75.23 & 75.13 \\
\hline 21 & 75.35 & 75.37 & 75.33 & 75.22 & 75.25 & 75.17 & 75.20 & 75.10 & 75.19 & 75.11 & 75.16 & 75.13 \\
\hline 22 & 75.31 & 75.37 & 75.32 & 75.21 & 75.19 & 75.11 & 75.17 & 75.08 & 75.16 & 75.15 & 75.21 & 75.12 \\
\hline 23 & 75.29 & 75.25 & 75.31 & 75.20 & 75.17 & 75.14 & 75.17 & 75.09 & 75.16 & 75.13 & 75.23 & 75.13 \\
\hline 24 & 75.33 & 75.26 & 75.32 & 75.31 & 75.25 & 75.15 & 75.20 & 75.14 & 75.14 & 75.17 & ............. & 75.14 \\
\hline 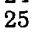 & 75.40 & 75.33 & 75.21 & 75.30 & 75.31 & 75.25 & 75.17 & 75.16 & 75.12 & 75.11 & & 75.17 \\
\hline 26 & 75.45 & 75.33 & 75.26 & 75.32 & 75.25 & 75.27 & 75.15 & 75.14 & 75.08 & 75.12 & & 75.19 \\
\hline 27 & & 75.27 & 75.35 & 75.32 & 75.23 & 75.22 & 75.14 & 75.12 & 75.18 & 75.12 & $\ldots$ & 75.10 \\
\hline 28 & & 75.34 & 75.45 & 75.26 & 75.20 & 75.25 & 75.11 & 75.14 & 75.17 & 75.14 & $\cdots$ & 75.07 \\
\hline 0 & 75.37 & & 75.47 & 75.32 & 75.21 & 75.22 & 75.12 & 75.15 & 75.08 & 75.12 & ........... & 75.12 \\
\hline$=$ & 75.32 & & & 75.30 & 75.27 & 75.18 & 75.13 & 75.12 & 75.14 & 75.08 & & 75.10 \\
\hline & & & & ......... & 75.27 & ......... & 75.19 & 75.13 & ............... & 75.13 & $\cdots$ & 75.14 \\
\hline
\end{tabular}

\begin{tabular}{c|c||c|c||c|c}
\hline Date & $\begin{array}{l}\text { Water } \\
\text { level }\end{array}$ & Date & $\begin{array}{l}\text { Water } \\
\text { level }\end{array}$ & Date & $\begin{array}{l}\text { Water } \\
\text { level }\end{array}$ \\
\hline
\end{tabular}

\section{DUNDY COUNTY}

\begin{tabular}{l|l||l|l||ll|l|l}
\hline Feb. 3,1948 & 61.02 & Aug. 3,1948 & 61.15 & Dec. & 7,1948 & 60.92 \\
Apr. 10 & 60.85 & Oct. & 6 & 61.29 & Feb. & 8,1949 & 60.84
\end{tabular}


Water-level measurements in wells, in feet below land-surface datum, with recorder chart readings of lowest daily water levels in 1950 - Continued

\begin{tabular}{c|c||l|l||l|l}
\hline Date & $\begin{array}{l}\text { Water } \\
\text { level }\end{array}$ & Date & $\begin{array}{l}\text { Water } \\
\text { level }\end{array}$ & Date & $\begin{array}{l}\text { Water } \\
\text { level }\end{array}$ \\
\hline
\end{tabular}

\section{DUNDY COUNTY-Continued}

1-37-7ab-Continued

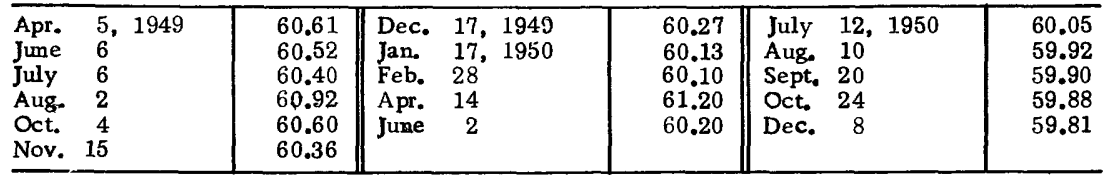

$1-37-16 \mathrm{dd}$

\begin{tabular}{|c|c|c|c|c|c|c|c|c|}
\hline $\begin{array}{l}\text { Feb. } \\
\text { Apr. } \\
\text { June } \\
\text { Aug. } \\
\text { Oct. } \\
\text { Dec. } \\
\text { Feb. } \\
\text { Apr. }\end{array}$ & $\begin{aligned} 4, & 1948 \\
12 & \\
9 & \\
4 & \\
6 & \\
7 & \\
8, & 1949 \\
5 & \end{aligned}$ & $\begin{array}{l}38.77 \\
38.87 \\
38.96 \\
38.75 \\
38.70 \\
38.77 \\
38.85 \\
38.63\end{array}$ & $\begin{array}{l}\text { June } \\
\text { Aug. } \\
\text { Oct. } \\
\text { Nov. } 1 \\
\text { Dec. } 1 \\
\text { Jan, } 1 \\
\text { Feb. } 2\end{array}$ & $\begin{array}{rr}6, & 1949 \\
3 & \\
4 & \\
15 & \\
18 & \\
17, & 1950 \\
28 & \end{array}$ & $\begin{array}{l}38.54 \\
38.40 \\
37.92 \\
37.91 \\
37.97 \\
38.03 \\
38.14\end{array}$ & $\begin{array}{l}\text { Apr. } \\
\text { June } \\
\text { July } \\
\text { Aug. } \\
\text { Sept. } \\
\text { Oct. } 2 \\
\text { Dec. }\end{array}$ & $\begin{array}{rr}14, & 1950 \\
2 & \\
12 & \\
10 & \\
20 & \\
24 & \\
8 & \end{array}$ & $\begin{array}{l}38.22 \\
38.30 \\
38.38 \\
38.46 \\
38.43 \\
38.48 \\
38.59\end{array}$ \\
\hline
\end{tabular}

$1-37-19 b a$

\begin{tabular}{|c|c|c|c|c|c|c|c|c|}
\hline $\begin{array}{l}\text { Feb. } \\
\text { Apr. } \\
\text { June } \\
\text { Aug. } \\
\text { Oct. } \\
\text { Dec. } \\
\text { Feb. } \\
\text { Apr. }\end{array}$ & $\begin{array}{rr}3, & 1948 \\
10 & \\
8 & \\
3 & \\
5 & \\
7 & \\
8, & 1949 \\
5 & \end{array}$ & $\begin{array}{r}9.30 \\
9.63 \\
11.15 \\
11.95 \\
14.00 \\
10.59 \\
11.28 \\
7.12\end{array}$ & $\begin{array}{l}\text { June } \\
\text { July } \\
\text { Aug. } \\
\text { Sept. } \\
\text { Oct. } \\
\text { Nov. } \\
\text { Dec. } \\
\text { Jan. }\end{array}$ & $\begin{aligned} 6, & 1949 \\
1 * & \\
2 & \\
13^{*} & \\
4 & \\
16 & \\
18 & \\
17, & 1950\end{aligned}$ & $\begin{array}{r}9.11 \\
10.18 \\
12.22 \\
12.56 \\
13.38 \\
13.16 \\
13.20 \\
13.12\end{array}$ & $\begin{array}{l}\text { Feb. } \\
\text { Apr. } \\
\text { June } \\
\text { July } \\
\text { Aug. } \\
\text { Sept. } \\
\text { Oct. } \\
\text { Dec. }\end{array}$ & $\begin{aligned} 28, & 1950 \\
21 & \\
2 & \\
12 & \\
10 & \\
20 & \\
24 & \\
8 & \end{aligned}$ & $\begin{array}{l}12.59 \\
12.77 \\
12.91 \\
13.83 \\
14.01 \\
13.50 \\
14.47 \\
13.66\end{array}$ \\
\hline
\end{tabular}

$1-37-31 \mathrm{~cd}$

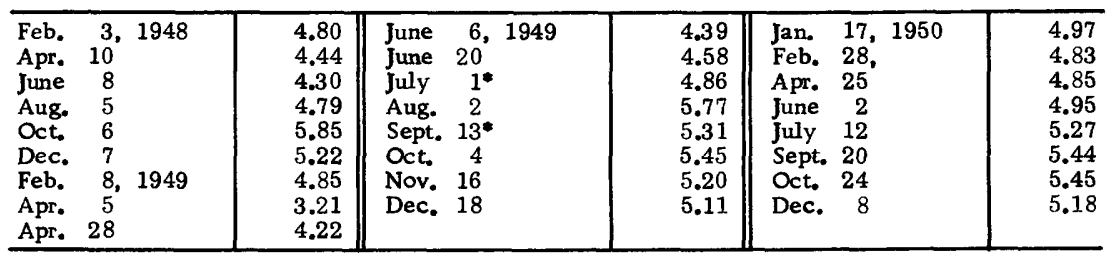

$1-38-20 b d$

\begin{tabular}{ll|r||l|l||l|l|}
\hline Feb. & 3,1948 & 15.72 & Oct. 4, 1949 & 15.02 & Mar. 1, 1950 & 15.02 \\
Apr. & 9 & 15.71 & Nov. 16 & 15.04 & Apr. 21 & 14.93 \\
June & 8 & 15.50 & Dec. 18 & 14.99 & Oct. 24 & 14.75 \\
Apr. & 5,1949 & 14.83 & Jan. 17, 1950 & 14.99 & Dec. 8 & 14.88 \\
Aug. & 2 & 14.75 & & & & \\
\hline
\end{tabular}

$1-38-21 \mathrm{cb}$

\begin{tabular}{ll|r||l|l||l|l}
\hline Oct. & 5,1948 & 6.43 & Sept. 13, 1949* & 5.50 & June 2, 1950 & 4.50 \\
Dec. & 7 & 5.69 & Oct. 4 & 5.45 & July 12 & 3.74 \\
Feb. & 8,1949 & 5.35 & Nov. 16 & 5.25 & Aug. 10 & 3.75 \\
Apr. 5 & 4.15 & Dec. 18 & 4.93 & Sept. 20 & 3.99 \\
June & 6 & 5.20 & Jan. 17, 1950 & 4.85 & Oct. 24 & .4 .51 \\
July 8 & 4.48 & Mar. 1 & 4.65 & Dec. 8 & 4.56 \\
Aug. 2 & 5.44 & Apr. 21 & 4.51 & & & \\
\hline
\end{tabular}


Water-level measurements in wells, in feet below land-surface datum, with recorder chart readings of lowest daily water levels in 1950-Continued

\begin{tabular}{c|c||l|l||l|l}
\hline Date & $\begin{array}{l}\text { Water } \\
\text { level }\end{array}$ & Date & $\begin{array}{l}\text { Water } \\
\text { level }\end{array}$ & Date & $\begin{array}{l}\text { Water } \\
\text { level }\end{array}$ \\
\hline
\end{tabular}

\section{DUNDY COUNTY-Continued}

$1-38-26 \mathrm{ca}$

\begin{tabular}{|c|c|c|c|c|c|c|c|c|}
\hline $\begin{array}{l}\text { Feb. } \\
\text { Apr. } 1 \\
\text { June } \\
\text { Aug. } \\
\text { Dec. } \\
\text { Feb. } \\
\text { Apr. } \\
\text { June }\end{array}$ & $\begin{array}{rr}3, & 1948 \\
10 & \\
8 & \\
3 & \\
7 & \\
8, & 1949 \\
5 & \\
6 & \end{array}$ & $\begin{array}{l}13.19 \\
12.91 \\
12.32 \\
12.84 \\
13.02 \\
12.79 \\
11.72 \\
11.55\end{array}$ & $\begin{array}{l}\text { July } \\
\text { Aug. } \\
\text { Oct. } \\
\text { Nov. 1 } \\
\text { Dec. 1 } \\
\text { Jan. 1 } \\
\text { Mar. }\end{array}$ & $\begin{array}{rr}8, & 1949 \\
2 & \\
4 & \\
16 & \\
18 & \\
17, & 1950 \\
1 & \end{array}$ & $\begin{array}{l}11.76 \\
12.72 \\
13.17 \\
12.97 \\
12.90 \\
12.75 \\
13.21\end{array}$ & $\begin{array}{l}\text { Apr. } \\
\text { June } \\
\text { July. } \\
\text { Aug. } \\
\text { Sept. } \\
\text { Oct. } 2 \\
\text { Dec. }\end{array}$ & $\begin{array}{rr}21, & 1950 \\
2 & \\
12 & \\
11 & \\
20 & \\
24 & \\
8 & \end{array}$ & $\begin{array}{l}12.58 \\
12.64 \\
12.68 \\
12.25 \\
12.71 \\
13.07 \\
13.00\end{array}$ \\
\hline
\end{tabular}

$1-38-28 \mathrm{da}$

\begin{tabular}{|c|c|c|c|c|c|c|c|c|c|}
\hline $\begin{array}{l}\text { Apr. } \\
\text { Jume } \\
\text { Aug. } \\
\text { Oct. } \\
\text { Dec. } \\
\text { Feb. } \\
\text { Apr. }\end{array}$ & $\begin{array}{c}10 \\
8 \\
3 \\
5 \\
7 \\
8 \\
5\end{array}$ & 1949 & $\begin{array}{l}19.69 \\
19.95 \\
19.85 \\
20.42 \\
20.18 \\
19.75 \\
19.32\end{array}$ & $\begin{array}{l}\text { June } \\
\text { Aug. } \\
\text { Oct. } \\
\text { Nov. } \\
\text { Dec. } \\
\text { Jan. } \\
\text { Mar. }\end{array}$ & $\begin{array}{rr}6, & 1949 \\
2 & \\
4 & \\
16 & \\
18 & \\
17, & 1950 \\
1 & \end{array}$ & $\begin{array}{l}18.86 \\
19.24 \\
19.45 \\
19.28 \\
19.53 \\
19.46 \\
19.39\end{array}$ & $\begin{array}{l}\text { Apr. } \\
\text { June } \\
\text { July } \\
\text { Aug. } \\
\text { Sept. } \\
\text { Oct. } \\
\text { Dec. }\end{array}$ & $\begin{array}{rr}21, & 1950 \\
2 & \\
12 & \\
10 & \\
20 & \\
24 & \\
8 & \end{array}$ & $\begin{array}{l}19.50 \\
19.64 \\
19.55 \\
19.56 \\
19.67 \\
19.84 \\
19.88\end{array}$ \\
\hline
\end{tabular}

1-38-29ad

\begin{tabular}{|c|c|c|c|c|c|c|c|}
\hline $\begin{array}{l}\text { Feb. } \\
\text { Apr. } 1 \\
\text { June } \\
\text { Aug. } \\
\text { Oct. } \\
\text { Dec. } \\
\text { Feb. } \\
\text { Apr. }\end{array}$ & $\begin{array}{rr}3, & 1948 \\
10 & \\
8 & \\
3 & \\
5 & \\
7 & \\
8, & 1949 \\
5 & \end{array}$ & $\begin{array}{l}8.11 \\
8.18 \\
8.40 \\
8.68 \\
9.03 \\
8.13 \\
7.52 \\
7.74\end{array}$ & $\begin{array}{l}\text { June } \\
\text { July } \\
\text { Aug. } \\
\text { Oct. } \\
\text { Nov. } \\
\text { Dec. } \\
\text { Jan. } \\
\text { Mar. }\end{array}$ & $\begin{array}{rr}6, & 1949 \\
8 & \\
2 & \\
4 & \\
16 & \\
18 & \\
17, & 1950 \\
1 & \end{array}$ & $\begin{array}{l}7.71 \\
8.14 \\
8.67 \\
8.31 \\
8.17 \\
7.95 \\
7.63 \\
7.97\end{array}$ & 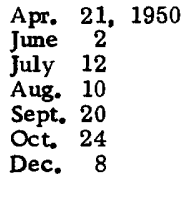 & $\begin{array}{l}7.03 \\
8.29 \\
8.19 \\
8.09 \\
8.39 \\
8.53 \\
8.34\end{array}$ \\
\hline
\end{tabular}

1-39-21ac

\begin{tabular}{|c|c|c|c|c|c|c|c|c|}
\hline $\begin{array}{l}\text { Feb. } \\
\text { Apr. } 1 \\
\text { June } \\
\text { Aug. } \\
\text { Oct. } \\
\text { Dec. } \\
\text { Feb. } \\
\text { Apr. }\end{array}$ & $\begin{array}{rr}3, & 1948 \\
10 & \\
8 & \\
3 & \\
5 & \\
7 & \\
8, & 1949 \\
5 & \end{array}$ & $\begin{array}{l}4.62 \\
5.28 \\
5.43 \\
5.30 \\
5.74 \\
5.20 \\
4.40 \\
4.27\end{array}$ & $\begin{array}{l}\text { June } \\
\text { Aug. } \\
\text { Oct. } \\
\text { Nov. } \\
\text { Dec. } \\
\text { Jan. } \\
\text { Mar. }\end{array}$ & $\begin{aligned} 6, & 1949 \\
2 & \\
4 & \\
16 & \\
18 & \\
17, & 1950 \\
1 & \end{aligned}$ & $\begin{array}{l}4.85 \\
5.90 \\
5.63 \\
5.40 \\
5.40 \\
5.32 \\
5.31\end{array}$ & $\begin{array}{ll}\text { Apr. } & 2 \\
\text { June } & \\
\text { July } & 1 \\
\text { Aug. } & 1 \\
\text { Sept. } & 2 \\
\text { Oct. } & 2 \\
\text { Dec. } & \end{array}$ & $\begin{array}{rr}21, & 1950 \\
2 & \\
12 & \\
10 & \\
20 & \\
24 & \\
8 & \end{array}$ & $\begin{array}{l}5.13 \\
5.21 \\
5.35 \\
5.10 \\
5.40 \\
5.35 \\
4.67\end{array}$ \\
\hline
\end{tabular}

$1-39-22 \mathrm{cc}$

\begin{tabular}{|c|c|c|c|c|c|c|c|c|}
\hline $\begin{array}{l}\text { Feb. } \\
\text { Apr. } 1 \\
\text { June } \\
\text { Aug. } \\
\text { Oct. } \\
\text { Dec. } \\
\text { Apr. } \\
\text { June }\end{array}$ & $\begin{array}{cc}3, & 1948 \\
10 & \\
8 & \\
3 & \\
5 & \\
7 & \\
5, & 1949 \\
6 & \end{array}$ & $\begin{array}{l}11.75 \\
11.62 \\
11.20 \\
11.38 \\
12.69 \\
11.60 \\
10.50 \\
10.80\end{array}$ & $\begin{array}{l}\text { July } \\
\text { Aug. } \\
\text { Oct. } \\
\text { Nov. } 1 \\
\text { Dec. } 1 \\
\text { Jan. } 1 \\
\text { Mar. }\end{array}$ & $\begin{array}{rr}8, & 1949 * \\
2 & \\
4 & \\
16 & \\
18 & \\
17, & 1950 \\
1 & \end{array}$ & $\begin{array}{l}13.37 \\
12.60 \\
12.38 \\
12.02 \\
11.82 \\
11.49 \\
11.62\end{array}$ & $\begin{array}{l}\text { Apr. } 2 \\
\text { June } \\
\text { July } 1 \\
\text { Aug. } 1 \\
\text { Sept. } 2 \\
\text { Oct. } 2 \\
\text { Dec. }\end{array}$ & $\begin{aligned} 21, & 1950 \\
2 & \\
12 & \\
10 & \\
20 & \\
24 & \\
8 & \end{aligned}$ & $\begin{array}{l}11.57 \\
11.70 \\
12.32 \\
11.65 \\
11.81 \\
12.08 \\
11.70\end{array}$ \\
\hline
\end{tabular}

1-39-26aа

\begin{tabular}{|c|c|c|c|c|c|c|}
\hline $\begin{array}{l}\text { Feb. } \\
\text { Apr. } \\
\text { June } \\
\text { Aug. } \\
\text { Oct. } \\
\text { Dec. } \\
\text { Feb. } \\
\text { Apr. }\end{array}$ & $\begin{array}{rr}3, & 1948 \\
10 & \\
8 & \\
3 & \\
5 & \\
7 & \\
8, & 1949 \\
5 & \end{array}$ & $\begin{array}{l}25.64 \\
25.34 \\
25.90 \\
25.58 \\
26.50 \\
25.68 \\
25.07 \\
24.77\end{array}$ & $\begin{array}{lrl}\text { June } & 6, & 1949 \\
\text { July } & 8 * & \\
\text { Aug. } & 2 & \\
\text { Oct. } & 4 & \\
\text { Nov. } & 16 & \\
\text { Dec. } & 18 & \\
\text { Jan. } & 17, & 1950 \\
\text { Mar. } & 1 & \end{array}$ & $\begin{array}{l}24.84 \\
24.87 \\
25.30 \\
25.50 \\
25.04 \\
24.86 \\
24.71 \\
24.54\end{array}$ & $\begin{array}{lrl}\text { Apr. } & 21, & 1950 \\
\text { June } & 2 & \\
\text { July } & 12 & \\
\text { Aug. } & 10 & \\
\text { Sept. } & 20 & \\
\text { Oct. } & 24 & \\
\text { Dec. } & 8 & \end{array}$ & $\begin{array}{l}24.49 \\
24.71 \\
25.27 \\
25.18 \\
24.90 \\
24.88 \\
24.56\end{array}$ \\
\hline
\end{tabular}


GROUND-WATER GEOLOGY, REPUBLICAN AND FRENCHMAN VALLEYS, NEBR. 639

Water-level measurements in wells, in feet below land-surface datum, with recorder chart readings of lowest daily water levels in 1950-Continued

\begin{tabular}{l|l||l|l||l|l}
\hline Date & $\begin{array}{l}\text { Water } \\
\text { level }\end{array}$ & Date & $\begin{array}{l}\text { Water } \\
\text { level }\end{array}$ & Date & $\begin{array}{l}\text { Water } \\
\text { level }\end{array}$ \\
\hline
\end{tabular}

DUNDY COUNTY-Continued

$1-39-30 b b$

\begin{tabular}{|c|c|c|c|c|c|c|c|c|c|}
\hline $\begin{array}{l}\text { Feb. } \\
\text { Apr. } \\
\text { June } \\
\text { Aug. } \\
\text { Oct. } \\
\text { Dec. } \\
\text { Feb. } \\
\text { Apr. }\end{array}$ & $\begin{array}{r}3, \\
10 \\
8 \\
3 \\
5 \\
7 \\
8 \\
5\end{array}$ & $\begin{array}{l}1948 \\
1949\end{array}$ & $\begin{array}{l}12.08 \\
11.94 \\
11.37 \\
11.04 \\
12.28 \\
12.17 \\
11.55 \\
10.98\end{array}$ & $\begin{array}{l}\text { June } \\
\text { July } \\
\text { Aug. } \\
\text { Oct. } \\
\text { Nov. } \\
\text { Dec. } \\
\text { Jan. } \\
\text { Mar. }\end{array}$ & $\begin{array}{rr}6, & 1949 \\
6 & \\
2 & \\
4 & \\
16 & \\
18 & \\
17, & 1950 \\
1 & \end{array}$ & $\begin{array}{r}8.23 \\
11.41 \\
12.46 \\
12.58 \\
12.28 \\
12.15 \\
11.84 \\
11.75\end{array}$ & $\begin{array}{l}\text { Apr. } \\
\text { June } \\
\text { July } \\
\text { Aug. } \\
\text { Sept. } \\
\text { Oct. } \\
\text { Dec. }\end{array}$ & $\begin{array}{rr}21, & 1950 \\
2 & \\
12 & \\
10 & \\
20 & \\
24 & \\
8 & \end{array}$ & $\begin{array}{r}11.94 \\
12.14 \\
12.58 \\
9.86 \\
11.69 \\
12.37 \\
12.51\end{array}$ \\
\hline
\end{tabular}

$1-40-20 \mathrm{cb}$

\begin{tabular}{|c|c|c|c|c|c|c|c|c|}
\hline $\begin{array}{l}\text { Feb. } \\
\text { Apr. } \\
\text { June } \\
\text { Aug. } \\
\text { Oct. } \\
\text { Dec. } \\
\text { Feb. } \\
\text { Apr. }\end{array}$ & $\begin{array}{rr}3, & 1948 \\
10 & \\
8 & \\
3 & \\
5 & \\
7 & \\
8, & 1949 \\
5 & \end{array}$ & $\begin{array}{l}3.40 \\
3.42 \\
3.88 \\
3.65 \\
4.32 \\
3.60 \\
2.87 \\
1.80\end{array}$ & $\begin{array}{l}\text { June } \\
\text { July } \\
\text { Aug. } \\
\text { Oct. } \\
\text { Nov. } \\
\text { Dec. } \\
\text { Jan. } \\
\text { Mar. }\end{array}$ & $\begin{aligned} 7, & 1949 \\
5 & \\
2 & \\
4 & \\
16 & \\
18 & \\
17, & 1950 \\
1 & \end{aligned}$ & $\begin{array}{l}2.75 \\
3.53 \\
4.02 \\
4.19 \\
3.67 \\
3.48 \\
3.19 \\
3.27\end{array}$ & $\begin{array}{l}\text { Apr. } \\
\text { June } \\
\text { July } \\
\text { Aug. } \\
\text { Sept. } \\
\text { Oct. } \\
\text { Dec. }\end{array}$ & $\begin{aligned} 21, & 1950 \\
2 & \\
12 & \\
10 & \\
20 & \\
24 & \\
8 & \end{aligned}$ & $\begin{array}{l}3.44 \\
3.73 \\
3.85 \\
2.08 \\
2.60 \\
3.49 \\
3.30\end{array}$ \\
\hline
\end{tabular}

$1-40-24 \mathrm{~cd}$

\begin{tabular}{lr|r||lr|r||lr|r}
\hline Feb. 3,1948 & 8.40 & Aug. 2, 1949 & 8.59 & Apr. & 21,1950 & 7.89 \\
Apr. 10 & 8.29 & Oct. 4 & 8.27 & June & 2 & 7.98 \\
June & 8 & 8.45 & Nov. 16 & 8.10 & July & 12 & 8.18 \\
Aug. & 3 & 8.21 & Dec. 18 & 7.95 & Sept. 20 & 8.33 \\
Oct. & 5 & 8.72 & Jan. 17, 1950 & 7.72 & Oct. 24 & 8.36 \\
Dec. & 7 & 8.39 & Mar. 1 & 7.84 & Dec. & 8 & 8.25 \\
June & 6,1949 & 7.70 & & & & & \\
\hline
\end{tabular}

1-40-27ab

\begin{tabular}{lr|r||lr|r||lr|r}
\hline Feb. & 3,1948 & 19.70 & Apr. 5,1949 & 18.67 & Apr. & 21,1950 & 18.82 \\
Apr. 10 & 19.40 & June & 6 & 18.40 & June & 2 & 18.86 \\
June & 8 & 19.60 & Oct. 4 & 19.33 & July & 11 & 19.48 \\
Aug. & 3 & 19.05 & Nov. 16 & 19.15 & Aug. & 10 & 18.62 \\
Oct. & 5 & 19.50 & Dec. 18 & 19.11 & Sept. 20 & 18.51 \\
Dec. & 7 & 19.35 & Jan. 17, 1950 & 19.00 & Dec. & 8 & 19.09 \\
Feb. 8,1949 & 19.10 & Mar. 1 & 18.92 & & & \\
\hline
\end{tabular}

1-40-29bb

\begin{tabular}{|c|c|c|c|c|c|c|c|c|c|c|c|c|}
\hline \multirow{2}{*}{ Day } & \multicolumn{12}{|c|}{ Month } \\
\hline & Jan. & Feb. & Mar. & Apr. & May & June & July & Aug. & Sept. & Oct. & Nov. & Dec. \\
\hline $\begin{array}{r}1 \\
2 \\
3 \\
4 \\
5 \\
6 \\
7 \\
8 \\
9 \\
10 \\
11 \\
12\end{array}$ & $\begin{array}{l}11.53 \\
11.53 \\
11.52 \\
11.52 \\
11.51 \\
11.52 \\
11.52 \\
11.53 \\
11.53 \\
11.52 \\
11.51 \\
11.52\end{array}$ & 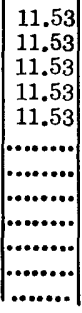 & 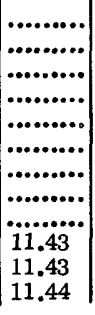 & $\begin{array}{l}11.45 \\
11.45 \\
11.45 \\
11.47 \\
11.47 \\
11.47 \\
11.45 \\
11.45 \\
11.45 \\
11.46 \\
11.47 \\
11.47\end{array}$ & $\begin{array}{l}11.50 \\
11.49 \\
11.49 \\
11.49 \\
11.49 \\
11.50 \\
11.51 \\
11.51 \\
11.51 \\
11.51 \\
11.50 \\
11.50\end{array}$ & $\begin{array}{l}11.55 \\
11.56 \\
11.57 \\
11.58 \\
11.58 \\
11.59 \\
11.60 \\
11.60 \\
11.61 \\
11.62 \\
11.62 \\
11.63\end{array}$ & $\begin{array}{l}11.80 \\
11.80 \\
11.81 \\
11.82 \\
11.83 \\
11.83 \\
11.84 \\
11.85 \\
11.86 \\
11.87 \\
11.87 \\
11.88\end{array}$ & $\begin{array}{l}12.01 \\
12.02 \\
12.01 \\
11.95 \\
11.87 \\
11.80 \\
11.75 \\
11.70 \\
11.65 \\
11.45 \\
11.09 \\
10.88\end{array}$ & $\begin{array}{l}10.25 \\
10.26 \\
10.29 \\
10.30 \\
10.31 \\
10.32 \\
10.34 \\
10.36 \\
10.37 \\
10.40 \\
10.42 \\
10.43\end{array}$ & $\begin{array}{l}10.44 \\
10.47 \\
10.48 \\
10.49 \\
10.47 \\
10.47 \\
10.51 \\
10.52 \\
10.52 \\
10.54 \\
10.55 \\
10.56\end{array}$ & $\begin{array}{l}10.76 \\
10.78 \\
10.79 \\
10.79 \\
10.79 \\
10.81 \\
10.81 \\
10.83 \\
10.84 \\
10.84 \\
10.83 \\
10.85\end{array}$ & $\begin{array}{l}10.94 \\
10.96 \\
10.96 \\
10.96 \\
10.98 \\
10.98 \\
10.97 \\
10.97 \\
10.98 \\
10.98 \\
10.97 \\
10.97\end{array}$ \\
\hline
\end{tabular}


Water-level measurements in wells, in feet below land-surface datum, with recorder chart readings of lowest daily water levels in 1950-Continued

DUNDY COUNTY-Continued

1-40-29bb-Continued

\begin{tabular}{|c|c|c|c|c|c|c|c|c|c|c|c|c|}
\hline \multirow{2}{*}{ Day } & \multicolumn{12}{|c|}{ Month } \\
\hline & Jan. & Feb. & Mar. & Apr. & May & June & July & Aug. & Sept. & Oct. & Nov. & Dec. \\
\hline 13 & 11.52 & & 11.45 & 11.47 & 11.49 & 11.64 & 11.88 & 10.68 & 10.45 & 10.56 & 10.85 & 10.98 \\
\hline 14 & 11.52 & & 11.44 & 11.4 & 11.48 & 11.65 & 11.89 & 10.54 & 10. & 1 & 10 & 10.98 \\
\hline 15 & 11.52 & & 11.44 & 11.47 & 11.48 & 11.66 & 11.90 & 10.33 & 10.47 & 10.58 & 10.87 & 10.99 \\
\hline 16 & 11.52 & & 11.44 & 11.47 & 11.48 & 11.67 & 11.91 & 10.24 & 10.40 & 10.60 & 10.88 & 11.00 \\
\hline 17 & 11.52 & & 11.44 & 11.47 & 11.48 & 11.68 & 11.92 & 10.19 & 10.32 & 10.61 & 10.87 & 11.00 \\
\hline 18 & 11.54 & & 11.44 & 11.47 & 11.48 & 11.68 & 11.92 & 10.16 & 10.27 & 10.62 & 10.87 & 11.00 \\
\hline 19 & 11.55 & & 11.45 & 11.47 & 11.48 & 11.69 & 11.93 & 10.14 & 10.26 & 10.64 & 10.88 & 11.01 \\
\hline 20 & 11.55 & & 11.45 & 11.47 & 11.49 & 11.70 & 11.94 & 10.14 & 10.25 & 10.65 & 10.90 & 11.01 \\
\hline 21 & 11.55 & & 11.45 & 11.47 & 11.50 & 11.70 & 11.94 & 10.13 & 10.27 & 10.66 & 10.90 & 11.02 \\
\hline 22 & 11.54 & & 11.45 & 11.47 & 11.50 & 11.71 & 11.95 & 10.12 & 10.28 & 10.67 & 10.90 & 11.02 \\
\hline 23 & 11.54 & & 11.45 & 11.47 & 11.50 & 11.72 & 11.95 & 10.12 & 10.30 & 10.68 & 10.92 & 11.02 \\
\hline 24 & 11.53 & & 11.45 & 11.47 & 11.50 & 11.73 & 11.96 & 10.15 & 10.31 & 10.70 & 10.92 & 11.02 \\
\hline 25 & 11.53 & & 11.45 & 11.48 & 11.51 & 11.74 & 11.97 & 10.17 & 10. & 10.70 & 10.93 & 11.02 \\
\hline 26 & 11.53 & & 11.43 & 11.48 & 11.53 & 11.75 & 11.98 & 10.19 & 10.33 & 10.71 & 10.93 & 11.03 \\
\hline 27 & 11.54 & $\ldots$ & 11.44 & 11.49 & 11.54 & 11.76 & 11.98 & 10.20 & 10.36 & 10.72 & 10.93 & 11.03 \\
\hline 28 & 11.54 & & 11.45 & 11.49 & 11.54 & 11.77 & 11.98 & 10.22 & 10.37 & 10.73 & 10.94 & 11.03 \\
\hline 29 & 11.53 & & 11.47 & 11.49 & 11.54 & 11.78 & 11.99 & 10.24 & 10.39 & 10.74 & 10.94 & 11.04 \\
\hline 30 & 11.53 & & 11.47 & 11.50 & 11.54 & 11.79 & 12.00 & 10.24 & 10.40 & 10.74 & 10.94 & 11.04 \\
\hline 31 & & & 11.46 & .......... & 11.55 & ......... & 12.00 & 10.24 & ........... & 10.75 & ......... & 11.03 \\
\hline
\end{tabular}

\begin{tabular}{c|c||l|l||l|l}
\hline Date & $\begin{array}{l}\text { Water } \\
\text { level }\end{array}$ & Date & $\begin{array}{l}\text { Water } \\
\text { level }\end{array}$ & Date & $\begin{array}{l}\text { Water } \\
\text { level }\end{array}$ \\
\hline
\end{tabular}

$1-41-20 \mathrm{dd}$

\begin{tabular}{lr|r||l|l||l|l|}
\hline Feb. 3,1948 & 2.52 & June 6, 1949 & 2.70 & Apr. 21, 1950 & 2.93 \\
Apr. 10 & 2.90 & Aug. 2 & 4.10 & June 2 & 3.08 \\
June 8 & 3.14 & Sept. 13* & 3.09 & July 12 & 3.45 \\
Aug. 3 & 3.60 & Oct. 4 & 3.30 & Aug. 10 & 3.03 \\
Oct. 5 & 3.65 & Nov. 16 & 2.84 & Sept. 20 & 2.64 \\
Dec. 7 & 2.56 & Dec. 18 & 2.56 & Oct. 24 & 3.16 \\
Feb. 8,1949 & 2.18 & Jan. 17, 1950 & 2.43 & Dec. 8 & 2.68 \\
Apr. 5 & 1.75 & Mar. 1 & 2.54 & & \\
\hline
\end{tabular}

$1-41-27 \mathrm{ca}$

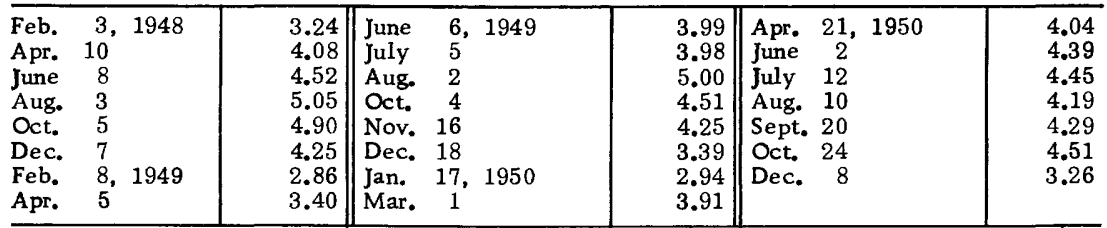

$1-42-10 \mathrm{~cd}$

\begin{tabular}{lr|r||lr|r||lr|r}
\hline Feb. 3,1948 & 4.35 & Apr. 5,1949 & 4.07 & Jan. 17, 1950 & 3.71 \\
Apr. 10 & 4.08 & June 6 & 3.92 & Mar. 1 & 3.68 \\
June 8 & 4.65 & Aug. 2 & 3.91 & Apr. 21 & 3.69 \\
Aug. 3 & 4.69 & Oct. 4 & 3.84 & June 2 & 3.67 \\
Oct. 5 & 5.25 & Nov. 16 & 3.77 & July 12 & 3.57 \\
Dec. 7 & 4.86 & Dec. 18 & 3.74 & Aug. 10 & 3.58 \\
Feb. 8,1949 & 4.27 & & & & \\
\hline
\end{tabular}


GROUND-WATER GEOLOGY, REPUBLICAN AND FRENCHMAN VALLEYS, NEBR, 641

Water-level measurements in wells, in feet below land-surface datum, with recorder chart readings of lowest daily water levels in 1950-Continued

\begin{tabular}{l|l|l|l||l|l|}
\hline Date & $\begin{array}{l}\text { Water } \\
\text { level }\end{array}$ & Date & $\begin{array}{l}\text { Water } \\
\text { level }\end{array}$ & Date & $\begin{array}{l}\text { Water } \\
\text { level }\end{array}$ \\
\hline
\end{tabular}

DUNDY COUNTY-Continued

$1-42-13 b b$

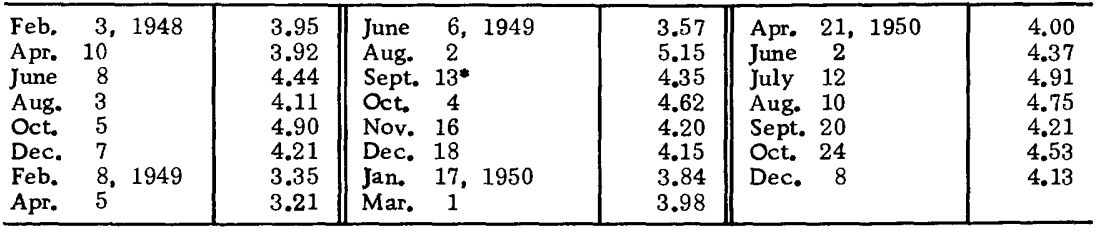

$1-42-36 a a$

\begin{tabular}{|c|c|c|c|c|c|c|c|}
\hline $\begin{array}{l}\text { Feb. } \\
\text { Apr. } \\
\text { June } \\
\text { Aug. } \\
\text { Oct. } \\
\text { Dec. } \\
\text { Feb. } \\
\text { Apr. }\end{array}$ & $\begin{array}{rr}3, & 1948 \\
10 & \\
8 & \\
3 & \\
5 & \\
7 & \\
8, & 1949 \\
5 & \end{array}$ & $\begin{array}{l}11.22 \\
11.04 \\
11.03 \\
11.44 \\
10.68 \\
11.23 \\
11.62 \\
10.18\end{array}$ & $\begin{array}{l}\text { June } \\
\text { Aug. } \\
\text { Sept. } \\
\text { Oct. } \\
\text { Nov. } \\
\text { Dec. } \\
\text { Jan. } 1 \\
\text { Mar. }\end{array}$ & $\begin{array}{rr}6, & 1949 \\
2 & \\
13^{*} & \\
4 & \\
16 & \\
18 & \\
17, & 1950 \\
1 & \end{array}$ & $\begin{array}{l}10.41 \\
12.20 \\
10.57 \\
10.72 \\
10.60 \\
11.25 \\
11.33 \\
10.99\end{array}$ & $\begin{array}{lr}\text { Apr. } & 21,1950 \\
\text { June } & 2 \\
\text { July } & 12 \\
\text { Aug. } & 10 \\
\text { Sept. } & 20 \\
\text { Oct. } & 24 \\
\text { Dec. } & 8\end{array}$ & $\begin{array}{r}11.33 \\
10.48 \\
10.24 \\
9.37 \\
10.22 \\
11.07 \\
10.60\end{array}$ \\
\hline
\end{tabular}

$2-36-24 c a$

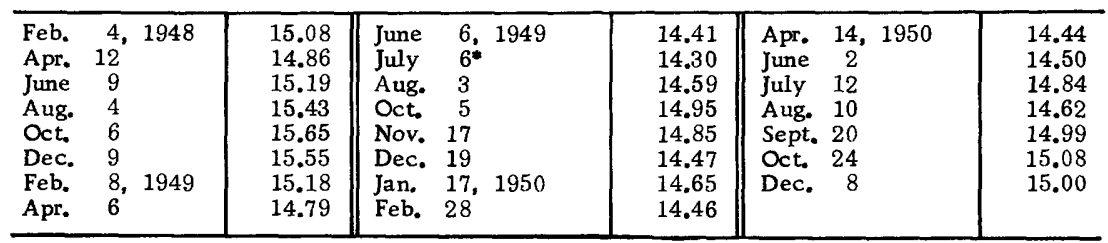

$2-36-24 c d$

\begin{tabular}{l|l|l|l|l|l|l|l|}
\hline Aug. 29, 1950 & 15.75 \\
Sept. 20 & 15.10 & Oct. 24, 1950 & 15.11 & Dec. 8,1950 & 15.00 \\
\hline
\end{tabular}

$2-36-29 a c$

\begin{tabular}{|c|c|c|c|c|c|c|c|}
\hline $\begin{array}{l}\text { Feb. } \\
\text { Apr. } \\
\text { June } \\
\text { Aug. } \\
\text { Oct. } \\
\text { Dec. } \\
\text { Feb. } \\
\text { Apr. }\end{array}$ & $\begin{array}{rr}4, & 1948 \\
12 & \\
9 & \\
4 & \\
6 & \\
9 & \\
8, & 1949 \\
6 & \end{array}$ & $\begin{array}{l}22.10 \\
21.92 \\
22.14 \\
22.48 \\
22.77 \\
22.40 \\
22.19 \\
21.33\end{array}$ & $\begin{array}{lr}\text { June } & 9, \\
\text { July } & 6^{*} \\
\text { Aug. } & 3 \\
\text { Oct. } & 5 \\
\text { Nov. } & 17 \\
\text { Dec. } & 19 \\
\text { Jan. } & 17,\end{array}$ & $\begin{array}{l}1949 \\
1950\end{array}$ & $\begin{array}{l}21.34 \\
21.44 \\
22.72 \\
22.15 \\
21.90 \\
21.70 \\
21.62\end{array}$ & 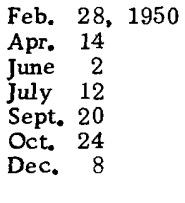 & $\begin{array}{l}21.52 \\
21.41 \\
21.49 \\
22.12 \\
22.01 \\
21.97 \\
21.75\end{array}$ \\
\hline
\end{tabular}

$2-36-31 b c$

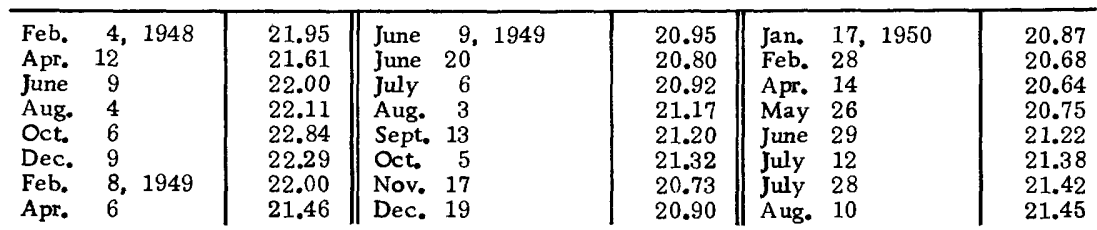


Water-level measurements in wells, in feet below land-surface datum, with recorder chart readings of lowest daily water levels in 1950- Continued

\begin{tabular}{c|c||c|c||c|c}
\hline Date & $\begin{array}{l}\text { Water } \\
\text { level }\end{array}$ & Date & $\begin{array}{l}\text { Water } \\
\text { level }\end{array}$ & Date & $\begin{array}{l}\text { Water } \\
\text { level }\end{array}$ \\
\hline
\end{tabular}

\section{DUNDY COUNTY-Continued}

$2-36-31 b c-$ Continued

\begin{tabular}{l|l||l|l||l|l|}
\hline Aug. 29, 1950 & $\begin{array}{l}21.35 \\
\text { Sept. } 20\end{array}$ & $\begin{array}{l}\text { Sept. 27, 1950 } \\
\text { Oct. 24 }\end{array}$ & $\begin{array}{l}21.56 \\
21.55\end{array}$ & Oov. 29, 1950 & 21.42 \\
\hline
\end{tabular}

$2-37-36 d b$

\begin{tabular}{l|l||l|l||l|l|}
\hline $\begin{array}{l}\text { Aug. 29, } 1950 \\
\text { Sept. 20 }\end{array}$ & $\begin{array}{l}19.74 \\
19.69\end{array}$ & Oct. 24, 1950 & 19.80 & Dec. 8, 1950 & 19.57 \\
\hline
\end{tabular}

FRONTIER COUNTY

5-26-11ac

\begin{tabular}{l|l||l|l||l|l|}
\hline Mar. 2, 1950 & 38.63 & Aug. 22, 1950 & 26.13 & Nov. 30, 1950 & 20.16 \\
May 22 & 33.39 & Sept. 22 & 23.61 & Dec. 19 & 19.45 \\
July 28 & 28.25 & Oct. 19 & 22.25 & & \\
\hline
\end{tabular}

5-26-11ba

\begin{tabular}{|c|c|c|c|c|c|c|c|}
\hline Aug. : & 20,1950 & 22.46 & & & & & \\
\hline \multicolumn{8}{|c|}{$5-26-11 d d$} \\
\hline $\begin{array}{l}\text { Mar. } \\
\text { May } \\
\text { July }\end{array}$ & $\begin{array}{cc}2, & 1950 \\
22 & \\
5 & \end{array}$ & $\begin{array}{l}59.77 \\
57.10 \\
54.99\end{array}$ & $\begin{array}{ll}\text { July } & 28 \\
\text { Aug. } & 22 \\
\text { Sept. } & 22\end{array}$ & 1950 & $\begin{array}{l}53.54 \\
52.13 \\
49.86\end{array}$ & $\begin{array}{lll}\text { Oct. } & 19, & 1950 \\
\text { Nov. } & 30 \\
\text { Dec. } & 19\end{array}$ & $\begin{array}{l}46.99 \\
45.18 \\
44.01\end{array}$ \\
\hline
\end{tabular}

$5-26-12 b c$

\begin{tabular}{l|l||l|l||l|l}
\hline Mar. 2, 1950 & 35.13 & Aug. 20, 1950 & 20.13 & Nov. 30, 1950 & 16.69 \\
June 14 & 26.51 & Sept. 22 & 18.78 & Dec. 19 & 15.96 \\
July 28 & 21.67 & Oct. 19 & 18.20 & & \\
\hline
\end{tabular}

5-26-13da

\begin{tabular}{|c|c|c|c|c|c|c|c|}
\hline July & 28,1950 & 95.40 & Aug. 20, & 1950 & 95.91 & Sept. 22, 1950 & 95.35 \\
\hline \multicolumn{8}{|c|}{$5-26-14 d c$} \\
\hline $\begin{array}{l}\text { Mar. } \\
\text { May } \\
\text { July }\end{array}$ & $\begin{array}{rr}2, & 1950 \\
22 & \\
5 & \end{array}$ & $\begin{array}{l}37.33 \\
30.06 \\
27.09\end{array}$ & $\begin{array}{ll}\text { July } & 28, \\
\text { Aug. } & 22 \\
\text { Sept. } & 22\end{array}$ & 1950 & $\begin{array}{l}23.53 \\
21.36 \\
19.87\end{array}$ & $\begin{array}{lll}\text { Oct. } & 19,1950 \\
\text { Nov. } & 30 \\
\text { Dec. } & 19\end{array}$ & $\begin{array}{l}19.13 \\
17.64 \\
16.99\end{array}$ \\
\hline
\end{tabular}

$5-26-25 a a b$

\begin{tabular}{l|l||l|l|l|l|l}
\hline Sept. 22, 1950 & $\begin{array}{l}39.40 \\
39.54\end{array}$ & Nov. 30, 1950 & 39.13 & Dec. 19, 1950 & 39.28 \\
Oct. 19 & & & & \\
\hline
\end{tabular}

5-26-25aad

\begin{tabular}{l|l||l|l||l|l|}
\hline Sept. 22, 1950 & $\begin{array}{l}12.69 \\
\text { Oct. } 19\end{array}$ & Nov. 30, 1950 & 12.44 & Dec. 19, 1950 & 12.47 \\
\hline
\end{tabular}


GROUंND-WATER GEOLOGY, REPUBLICAN AND FRENCHMAN VALLEYS, NEBR. 643

Water-level measurements in wells, in feet below land-surface datum, with recorder chart readings of lowest daily water levels in 1950 - Continued

\begin{tabular}{c|c||l|l||l|l}
\hline Date & $\begin{array}{l}\text { Water } \\
\text { level }\end{array}$ & Date & $\begin{array}{l}\text { Water } \\
\text { level }\end{array}$ & Date & $\begin{array}{l}\text { Water } \\
\text { level }\end{array}$ \\
\hline
\end{tabular}

FRONTIER COUNTY-Continued

$6-26-26 \mathrm{cb}$

\begin{tabular}{l|l||l|l||l|l|}
\hline Oct. 19,1950 & 59.36 & Nov. 30,1950 & 58.87 & Dec. 19,1950 & 58.64 \\
\hline
\end{tabular}

$6-26-29 b a$

\begin{tabular}{ll|l||ll|l||l|l|}
\hline Oct. 19,1950 & 40.40 & Nov. 30,1950 & 40.00 & Dec. 19, 1950 & 39.70 \\
\hline
\end{tabular}

$6-26-34 b a$

\begin{tabular}{l|l||l|l||l|l}
\hline Oct. 19,1950 & 104.81 & & & & \\
\hline
\end{tabular}

$6-26-34 d a$

\begin{tabular}{l|l||ll|l||l|l|}
\hline Aug. 20, 1950 & 52.24 & Oct. & 19,1950 & 49.44 & Dec. 19, 1950 & 46.52 \\
Sept. 22 & 50.71 & Nov. 30 & 47.38 & & \\
\hline
\end{tabular}

FURNAS COUNTY

$3-21-2 c c$

\begin{tabular}{|c|c|c|c|c|c|c|c|c|}
\hline $\begin{array}{l}\text { Feb. } \\
\text { Apr. } \\
\text { June } \\
\text { Aug. } \\
\text { Oct. } \\
\text { Dec. } \\
\text { Feb. } \\
\text { Apr. }\end{array}$ & $\begin{aligned} 5, & 1948 \\
13 & \\
11 & \\
5 & \\
7 & \\
10 & \\
10, & 1949 \\
7 & \end{aligned}$ & $\begin{array}{r}9.25 \\
9.07 \\
9.73 \\
8.63 \\
10.35 \\
9.72 \\
9.07 \\
8.07\end{array}$ & $\begin{array}{l}\text { June } \\
\text { Aug. } \\
\text { Oct. } \\
\text { Nov. } \\
\text { Dec. } \\
\text { Feb. } \\
\text { Mar. }\end{array}$ & $\begin{aligned} 10, & 1949 \\
5 & \\
7 & \\
19 & \\
21 & \\
8, & 1950 \\
20 & \end{aligned}$ & $\begin{array}{l}6.79 \\
9.04 \\
9.62 \\
9.27 \\
9.10 \\
8.71 \\
8.66\end{array}$ & $\begin{array}{l}\text { May } \\
\text { June } \\
\text { July } \\
\text { Aug. } \\
\text { Sept. } \\
\text { Oct. } \\
\text { Dec. }\end{array}$ & $\begin{array}{ll}5, & 1950 \\
27 & \\
21 & \\
17 & \\
18 & \\
24 & \\
12 & \end{array}$ & $\begin{array}{l}8.82 \\
8.80 \\
8.90 \\
8.73 \\
9.22 \\
9.34 \\
8.94\end{array}$ \\
\hline
\end{tabular}

\begin{tabular}{|c|c|c|c|c|c|c|}
\hline \multicolumn{7}{|c|}{$3-21-3 a d$} \\
\hline $\begin{array}{lrl}\text { Feb. } & 8,1950 \\
\text { Mar. } & 20 \\
\text { May } & 5\end{array}$ & $\begin{array}{l}10.92 \\
10.94 \\
11.03\end{array}$ & $\begin{array}{l}\text { June } \\
\text { July } \\
\text { Aug. }\end{array}$ & $\begin{array}{l}27,1950 \\
21 \\
17\end{array}$ & $\begin{array}{l}10.37 \\
10.30 \\
10.63\end{array}$ & $\begin{array}{ll}\text { Sept. } 18, & 1950 \\
\text { Oct. } 24 \\
\text { Dec. } 12\end{array}$ & $\begin{array}{l}11.04 \\
11.30 \\
11.51\end{array}$ \\
\hline \multicolumn{7}{|c|}{$3-21-4 c b$} \\
\hline $\begin{array}{lr}\text { Feb. } & 8,1950 \\
\text { Mar. } & 20 \\
\text { May } & 5\end{array}$ & $\begin{array}{r}10.02 \\
9.75 \\
9.55\end{array}$ & $\begin{array}{l}\text { June } \\
\text { July } \\
\text { Aug. }\end{array}$ & $\begin{array}{ll}27, & 1950 \\
21 & \\
17 & \end{array}$ & $\begin{array}{l}9.24 \\
9.64 \\
9.95\end{array}$ & $\begin{array}{l}\text { Sept. } 18,1950 \\
\text { Oct. } 24 \\
\text { Dec. } 12\end{array}$ & $\begin{array}{l}10.30 \\
10.59 \\
10.25\end{array}$ \\
\hline \multicolumn{7}{|c|}{$3-21-6 b b$} \\
\hline $\begin{array}{lrr}\text { Feb. } & 8, & 1950 \\
\text { Mar. } & 20 & \\
\text { May } & 5 & \end{array}$ & $\begin{array}{l}14.92 \\
14.84 \\
14.90\end{array}$ & $\begin{array}{l}\text { June } \\
\text { July } \\
\text { Aug. }\end{array}$ & $\begin{array}{ll}27, & 1950 \\
21 & \\
17 & \end{array}$ & $\begin{array}{l}15.30 \\
15.66 \\
15.51\end{array}$ & $\begin{array}{lll}\text { Sept. } & 18,1950 \\
\text { Oct. } 24 & \\
\text { Dec. } 12 & \end{array}$ & $\begin{array}{l}15.90 \\
15.98 \\
15.56\end{array}$ \\
\hline \multicolumn{7}{|c|}{$3-21-11 a a$} \\
\hline $\begin{array}{ll}\text { June } & 27,1950 \\
\text { July } & 21\end{array}$ & $\begin{array}{l}4.42 \\
4.70\end{array}$ & $\begin{array}{l}\text { Aug. } \\
\text { Sept. }\end{array}$ & $\begin{array}{l}17,1950 \\
18\end{array}$ & $\begin{array}{l}4.28 \\
4.51\end{array}$ & $\begin{array}{l}\text { Oct. } 24,1950 \\
\text { Dec. } 12\end{array}$ & $\begin{array}{l}4.39 \\
3.87\end{array}$ \\
\hline
\end{tabular}


Water-level measurements in wells, in feet below land-surface dat um, with recorder chart readings of lowest daily water levels in 1950-Continued

\begin{tabular}{c|c||c|c||c|c}
\hline Date & $\begin{array}{l}\text { Water } \\
\text { level }\end{array}$ & Date & $\begin{array}{l}\text { Water } \\
\text { level }\end{array}$ & Date & $\begin{array}{l}\text { Water } \\
\text { level }\end{array}$ \\
\hline
\end{tabular}

FURNAS COUNTY-Continued

$3-21-12 \mathrm{ad}$

\begin{tabular}{ll|l||l|l||ll|l|l|l|}
\hline June 27,1950 & 7.09 & Aug. 17,1950 & 7.35 & Oct. 24,1950 & 7.56 \\
July 21 & 7.56 & Sept. 18 & & 7.74 & Dec. 12 & 7.00 \\
\hline
\end{tabular}

$3-21-12 d c$

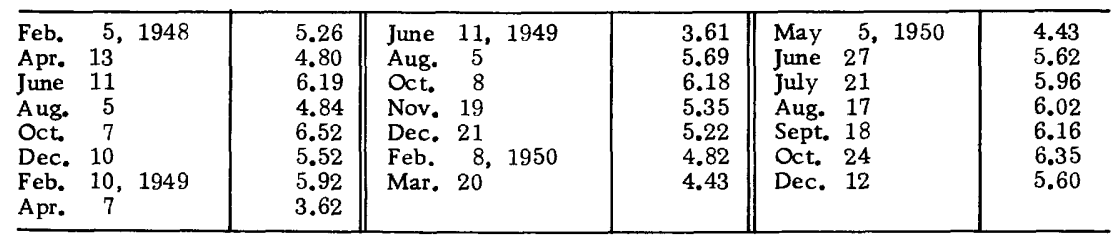

$3-22-2 b a$

\begin{tabular}{ll|l||lr|l||l|l|}
\hline Feb. & 2,1948 & 8.44 & May 26, 1949 & 6.50 & Mar. 17, 1950 & 8.45 \\
Apr. & 9 & 8.00 & June 6 & 6.85 & May 12 & 8.29 \\
June & 7 & 8.64 & July 8 & 7.27 & June 23 & 7.46 \\
Aug. & 2 & 7.68 & Aug. 1 & 6.60 & July 22 & 7.98 \\
Oct. & 1 & 8.84 & Oct. 3 & 8.67 & Aug. 18 & 8.12 \\
Dec. & 6 & 8.79 & Nov. 15 & 8.84 & Sept. 19 & 8.64 \\
Feb. & 7,1949 & 8.10 & Dec. 17 & 8.83 & Oct. 25 & 8.96 \\
Apr. 7 & 7.84 & Jan. 19, 1950 & 8.82 & Dec. 12 & 9.00 \\
\hline
\end{tabular}

$3-25-3 a b$

\begin{tabular}{lr|r||l|l||l|l|}
\hline May & 23,1950 & 35.52 & Aug. 17, 1950 & 35.87 & Oct. 18, 1950 & 35.46 \\
June & 9 & 35.45 & Sept. 17 & 35.62 & Dec. 5 & 35.53 \\
July 18 & 35.52 & & & & & \\
\hline
\end{tabular}

$3-25-4 a a$

\begin{tabular}{l|l||l|r||lc|c}
\hline June & 9,1950 & 13.63 & Aug. 17, 1950 & 9.60 & Oct. 18, 1950 & 11.60 \\
July 18 & 11.40 & Sept. 17 & 10.84 & Dec. 5 & 12.09 \\
\hline
\end{tabular}

$3-25-4 b b$

\begin{tabular}{|c|c|c|c|c|c|c|c|c|c|c|c|}
\hline \multirow{2}{*}{ Day } & \multicolumn{5}{|c|}{ Month } & \multirow{2}{*}{ Day } & \multicolumn{5}{|c|}{ Month } \\
\hline & May & June & July & Aug. & Sept. & & May & June & July & Aug. & Sept. \\
\hline 1 & & 4.45 & 5.06 & 3.66 & 4.48 & 13 & 5.00 & 4.67 & 5.08 & 4.15 & 4.71 \\
\hline $\overrightarrow{2}$ & & 4.45 & 5.09 & 3.73 & 4.50 & 14 & 4.95 & 4.70 & 5.08 & 4.17 & 4.73 \\
\hline 3 & 5.11 & 4.45 & 5.12 & 3.79 & 4.51 & 15 & 4.92 & 4.73 & 5.08 & 4.18 & 4.75 \\
\hline 4 & 5.12 & 4.45 & 5.14 & 3.86 & 4.53 & 16 & 4.90 & 4.75 & 5.09 & 4.21 & 4.76 \\
\hline 5 & 5.12 & 4.46 & 5.14 & 3.92 & 4.55 & 17 & 4.90 & 4.77 & 5.10 & 4.24 & 4.78 \\
\hline 6 & 5.11 & 4.47 & 5.14 & 3.97 & 4.57 & 18 & 4.90 & 4.78 & 5.11 & 4.27 & 4.79 \\
\hline 7 & 5.11 & 4.49 & 5.12 & 3.99 & 4.59 & 19 & 4.89 & 4.79 & 5.12 & 4.29 & 4.80 \\
\hline 8 & 5.11 & 4.51 & 5.10 & 4.02 & 4.61 & 20 & 4.86 & 4.81 & 5.13 & 4.31 & (a) \\
\hline 9 & 5.08 & 4.56 & 5.09 & 4.04 & 4.63 & 21 & 4.81 & 4.82 & 5.14 & 4.32 & ........... \\
\hline 10 & 5.04 & 4.58 & 5.08 & 4.07 & 4.65 & 22 & 4.76 & 4.84 & 5.15 & 4.34 & ........... \\
\hline 11 & 5.03 & 4.62 & 5.08 & 4.09 & 4.67 & 23 & 4.74 & 4.85 & 5.15 & 4.36 & \\
\hline 12 & 5.02 & 4.65 & 5.08 & 4.13 & 4.69 & 24 & 4.74 & 4.87 & 5.16 & 4.38 & ........... \\
\hline
\end{tabular}

${ }^{a}$ Water-level recording gage discontinued. Additional data: Water-level measurement on Oct. 18,1950 was 5.19 and on Dec. 5,1950 was 5.52 . 
GROUND-WATER GEOLOGY, REPUBLICAN AND FRENCHMAN VALLEYS, NEBR. 645

Water-level measurements in wells, in feet below land-surface datum with recorder chart readings of lowest daily water levels in 19.50 - Continued

FURNAS COUNTY-Continued

$3-25-4 b b-C o n t i n u e d$

\begin{tabular}{|c|c|c|c|c|c|c|c|c|c|c|c|}
\hline \multirow{2}{*}{ Day } & \multicolumn{5}{|c|}{ Month } & \multirow{2}{*}{ Day } & \multicolumn{5}{|c|}{ Month } \\
\hline & May & June & July & Aug. & Sept. & & May & June & July & Aug. & Sept. \\
\hline $\begin{array}{l}25 \\
26 \\
27 \\
28\end{array}$ & $\begin{array}{l}4.74 \\
4.74 \\
4.73 \\
4.69\end{array}$ & $\begin{array}{l}4.90 \\
4.92 \\
4.95 \\
4.98\end{array}$ & $\begin{array}{l}5.17 \\
5.17 \\
3.29 \\
3.38\end{array}$ & $\begin{array}{l}4.40 \\
4.42 \\
4.44 \\
4.45\end{array}$ & $\begin{array}{c}\ldots \ldots \ldots \ldots \\
\ldots \ldots \ldots \ldots \\
\ldots \ldots \ldots \ldots \\
\ldots \ldots \ldots \ldots\end{array}$ & $\begin{array}{l}29 \\
30 \\
31\end{array}$ & $\begin{array}{l}4.58 \\
4.50 \\
4.46\end{array}$ & $\begin{array}{c}5.00 \\
5.04 \\
\ldots \ldots\end{array}$ & $\begin{array}{l}3.46 \\
3.54 \\
3.60\end{array}$ & $\begin{array}{l}4.45 \\
4.46 \\
4.47\end{array}$ & $\mid \begin{array}{ll}\cdots & \ldots \\
\cdots & \ldots \ldots \ldots \\
\cdots & \ldots \ldots \ldots\end{array}$ \\
\hline
\end{tabular}

\begin{tabular}{l|l||l|l||l|l}
\hline Date & $\begin{array}{l}\text { Water } \\
\text { level }\end{array}$ & Date & $\begin{array}{l}\text { Water } \\
\text { level }\end{array}$ & Date & $\begin{array}{l}\text { Water } \\
\text { level }\end{array}$ \\
\hline
\end{tabular}

$3-25-5 b d$

\begin{tabular}{|r|r||l|l||l|l|l}
\hline June & 9,1950 & 2.67 & Aug. 15, 1950 & 2.69 & Oct. 18, 1950 & 3.31 \\
July 18 & 2.86 & Sept. 19 & 2.11 & Dec. 5 & 3.26 \\
\hline
\end{tabular}

$3-25-5 c a$

\begin{tabular}{|r|r||l|l||l|l|l}
\hline June & 9,1950 & 18.24 & Aug. 15, 1950 & 18.23 & Oct. 18, 1950 & 18.82 \\
July 18 & 18.35 & Sept. 19 & 18.54 & Dec. 5 & 18.85 \\
\hline
\end{tabular}

3-25-6ad

\begin{tabular}{|c|c|c|c|c|c|}
\hline $\begin{array}{lrl}\text { June } & 9,1950 \\
\text { July } & 18 & \end{array}$ & $\begin{array}{l}6.87 \\
7.04\end{array}$ & $\begin{array}{ll}\text { Aug. } & 15,1950 \\
\text { Sept. } & 19\end{array}$ & $\begin{array}{l}6.67 \\
7.36\end{array}$ & $\begin{array}{l}\text { Oct. } 18,1950 \\
\text { Dec. } 5\end{array}$ & $\begin{array}{l}7.63 \\
7.62\end{array}$ \\
\hline
\end{tabular}

4-21-29dc

\begin{tabular}{lr|l||l|l||l|l|}
\hline Feb. 8,1950 & 22.10 & June 27, 1950 & 21.75 & Sept. 18, 1950 & 21.92 \\
Mar. 20 & 22.03 & July 21 & 21.75 & Oct. 24 & 22.07 \\
May 5 & 21.99 & Aug. 17 & 21.82 & Dec. 12 & 22.02 \\
\hline
\end{tabular}

4-21-30cb

\begin{tabular}{l|l||l|l||l|l|}
\hline Feb. 8,1950 & 16.81 & June 23, 1950 & 16.36 & Sept. 18, 1950 & 16.85 \\
Mar. 20 & 16.60 & July 21 & 16.57 & Oct. 24 & 17.03 \\
May 5 & 16.41 & Aug. 17 & 16.74 & Dec. 12 & 16.77 \\
\hline
\end{tabular}

4-21-30dc

\begin{tabular}{|c|c|c|c|c|c|c|}
\hline $\begin{array}{l}\text { May } \\
\text { June } \\
\text { July }\end{array}$ & $\begin{array}{ll}18, & 1950 \\
23 & \\
21 & \end{array}$ & $\begin{array}{l}19.47 \\
21.24 \\
22.34\end{array}$ & $\begin{array}{l}\text { Aug. } 17,1950 \\
\text { Sept. } 18\end{array}$ & $\begin{array}{l}23.01 \\
23.46\end{array}$ & $\begin{array}{l}\text { Oct. } 24,1950 \\
\text { Dec. } 12\end{array}$ & $\begin{array}{l}23.92 \\
24.56\end{array}$ \\
\hline
\end{tabular}

4-21-31bb

\begin{tabular}{l|l||l|l||l|l|}
\hline Feb. 8,1950 & 24.55 & June 23, 1950 & 24.64 & Sept. 18, 1950 & 25.94 \\
Mar. 20 & 24.29 & July 21 & 25.34 & Oct. 24 & 26.23 \\
May 5 & 24.24 & Aug. 17 & 25.75 & Dec. 12 & 25.76 \\
\hline
\end{tabular}


Water-level measurements in wells, in feet below land-surface datum, with tecorder chart readings of lowest daily water levels in 1950 - Continued

\begin{tabular}{c|c||l|l||l|l}
\hline Date & $\begin{array}{l}\text { Water } \\
\text { level }\end{array}$ & Date & $\begin{array}{l}\text { Water } \\
\text { level }\end{array}$ & Date & $\begin{array}{l}\text { Water } \\
\text { level }\end{array}$ \\
\hline
\end{tabular}

FURNAS COUNTY-Continued

4-21-31bc

\begin{tabular}{l|l||ll|l|l|l|l}
\hline Feb. 8, 1950 & 16.02 & June 27, 1950 & 16.03 & Sept. 18, 1950 & 16.85 \\
Mar. 20 & 15.80 & July 21 & 16.55 & Oct. 24 & 17.13 \\
May 5 & 15.80 & Aug. 17 & 16.47 & Dec. 12 & 16.73 \\
\hline
\end{tabular}

$4-21-32 c c$

\begin{tabular}{lr|r||lr|r||lr|r}
\hline Feb. 5,1948 & 13.59 & Apr. 7,1949 & 13.76 & Mar. & 20,1950 & 13.87 \\
Apr. 13 & 13.30 & June 10 & 12.35 & May & 5 & 13.70 \\
June & 11 & 14.72 & Aug. & 5 & 14.37 & June & 27 & 13.10 \\
Aug. & 5 & 14.64 & Oct. 7 & 15.10 & July & 21 & 13.82 \\
Oct. & 7 & 15.59 & Nov. 19 & 14.35 & Sept. & 18 & 14.47 \\
Dec. 10 & 14.87 & Dec. 21 & 14.10 & Oct. 24 & 14.28 \\
Feb. 10,1949 & 14.39 & Feb. 8,1950 & 14.07 & Dec. & 12 & 13.85 \\
\hline
\end{tabular}

4-21-32dd

\begin{tabular}{l|l|l||l|l||ll|l}
\hline Feb. 8,1950 & 12.10 & June 27, 1950 & 11.10 & Sept. 18, 1950 & 11.87 \\
Mar. 20 & 11.80 & July 21 & 11.14 & Oct. 24 & 12.19 \\
May 5 & 11.54 & Aug. 17 & 11.49 & Dec. 12 & 12.12 \\
\hline
\end{tabular}

4-22-19ac

\begin{tabular}{lr|r||lr||l||ll|l}
\hline June & 10,1949 & 22.05 & Dec. 21, 1949 & 21.72 & July 21,1950 & 21.80 \\
July 18 & 21.84 & Feb. 7, 1950 & 21.72 & Aug. 17 & 21.80 \\
Aug. 5 & 21.75 & Mar. 20 & 21.73 & Sept. 18 & 21.72 \\
Sept. 9 & 21.66 & May 8 & 21.72 & Oct. 24 & 21.79 \\
Oct. & 7 & 21.65 & June 23 & 21.76 & Dec. 12 & 21.77 \\
Nov. 19 & 21.61 & & & & & \\
\hline
\end{tabular}

4-22-19ca

\begin{tabular}{lr|l||l|l||ll|l}
\hline June & 10,1949 & 1.00 & Nov. 19, 1949 & 5.75 & June & 23,1950 & 4.69 \\
July & 18 & 4.37 & Dec. 21 & 5.69 & Aug. & 17 & 5.89 \\
Aug. & 5 & 5.45 & Feb. 7, 1950 & 5.52 & Sept. 18 & 6.12 \\
Sept. 9 & 5.55 & Mar. 20 & 5.27 & Oct. 24 & 6.20 \\
Oct. 7 & 5.82 & May 8 & 5.03 & Dec. 12 & 5.92 \\
\hline
\end{tabular}

$4-22-19 c c$

\begin{tabular}{l|l||l|l||ll|l}
\hline Dec. 16, 1949 & 6.05 & June 23, 1950 & 4.97 & Sept. 18, 1950 & 6.24 \\
Feb. 7, 1950 & 5.95 & July 21 & 5.25 & Oct. 24 & 6.32 \\
Mar. 20 & 5.47 & Aug. 17 & 5.75 & Dec. 12 & 6.12 \\
May 8 & 5.47 & & & & & \\
\hline
\end{tabular}

$4-22-25 c c$

\begin{tabular}{|c|c|c|c|c|c|c|c|c|}
\hline $\begin{array}{l}\text { Feb. } \\
\text { Apr. } \\
\text { June } \\
\text { Aug. } \\
\text { Oct. } \\
\text { Dec. } \\
\text { Feb. } \\
\text { Apr. }\end{array}$ & $\begin{aligned} 4, & 1948 \\
13 & \\
11 & \\
5 & \\
7 & \\
10 & \\
10, & 1949 \\
7 & \end{aligned}$ & $\begin{array}{l}11.74 \\
11.24 \\
11.94 \\
11.15 \\
12.85 \\
12.53 \\
11.97 \\
11.15\end{array}$ & $\begin{array}{l}\text { June } 10 \\
\text { July } 1 \\
\text { Aug. } \\
\text { Sept. } \\
\text { Oct. } \\
\text { Nov. } 1 \\
\text { Dec. } 2 \\
\text { Feb. }\end{array}$ & $\begin{aligned} 10, & 1949 \\
18 & \\
5 & \\
9 & \\
7 & \\
19 & \\
21 & \\
8, & 1950\end{aligned}$ & $\begin{array}{r}9.32 \\
10.12 \\
11.45 \\
11.16 \\
12.52 \\
12.34 \\
12.35 \\
12.01\end{array}$ & $\begin{array}{l}\text { Mar. } \\
\text { May } \\
\text { Jume } \\
\text { July } \\
\text { Aug. } \\
\text { Sept. } \\
\text { Oct. } \\
\text { Dec. }\end{array}$ & $\begin{array}{cc}20, & 1950 \\
5 & \\
23 & \\
21 & \\
17 & \\
18 & \\
24 & \\
12 & \end{array}$ & $\begin{array}{l}11.79 \\
11.7 .5 \\
11.02 \\
12.40 \\
12.35 \\
12.63 \\
12.92 \\
12.61\end{array}$ \\
\hline
\end{tabular}


GROUND-WATER GEOLOGY, REPUBLICAN AND FRENCHMAN VALLEYS, NEBR. 647

Water-level measurements in wells, in feet below land-surface datum, with recorder chart readings of lowest daily water levels in 1950-Continued

\begin{tabular}{c|c|c|c||c|c|c|}
\hline Date & $\begin{array}{l}\text { Water } \\
\text { level }\end{array}$ & Date & $\begin{array}{l}\text { Water } \\
\text { level }\end{array}$ & $\begin{array}{l}\text { Water } \\
\text { level }\end{array}$ \\
\hline
\end{tabular}

\section{FURNAS COUNTY-Continued}

4-22-25dc

\begin{tabular}{lr|r||lll|r||l|l|l|}
\hline Feb. 8,1950 & 9.82 & Jume & 23,1950 & 9.06 & Sept. 18,1950 & 10.77 \\
Mar. 20 & 9.55 & July & 21 & & 9.97 & Oct. & 24 & 11.05 \\
May 5 & 9.50 & Aug. 17 & & 10.31 & Dec. & 12 & 10.70 \\
\hline
\end{tabular}

$4-22-26 c b$

\begin{tabular}{lr|l||ll|l||l|l|l|}
\hline Feb. 7,1950 & 11.19 & Jume 23,1950 & 11.01 & Sept. 18,1950 & 12.09 \\
Mar. 20 & 10.90 & July 21 & 11.92 & Oct. 24 & 12.48 \\
May 5 & 10.82 & Aug. 17 & 12.22 & Dec. 12 & 12.02 \\
\hline
\end{tabular}

4-22-27cb

\begin{tabular}{lr|l||ll|l||l|l|l|}
\hline Dec. 16,1949 & 18.32 & Jume 23,1950 & 18.64 & Sept. 18,1950 & 19.17 \\
Feb. 7,1950 & 18.51 & July 21 & 18.92 & Oct. 24 & 19.28 \\
Mar. 20 & 18.55 & Aug. 17 & 19.03 & Dec. 12 & 19.29 \\
May 8 & 18.66 & & & & & \\
\hline
\end{tabular}

4-22-29aa

\begin{tabular}{|c|c|c|c|c|c|c|c|}
\hline $\begin{array}{l}\text { June } \\
\text { July } \\
\text { Aug. } \\
\text { Sept. } \\
\text { Oct. } \\
\text { Nov. }\end{array}$ & $\begin{array}{l}10, \\
1949 \\
5 \\
9^{\star} \\
7 \\
19\end{array}$ & $\begin{array}{l}13.24 \\
13.30 \\
13.32 \\
13.22 \\
13.39 \\
13.15\end{array}$ & $\begin{array}{lrl}\text { Dec. } & 21, & 1949 \\
\text { Feb. } & 7, & 1950 \\
\text { Mar. } & 20 & \\
\text { May } & 8 & \\
\text { Jume } & 23 & \end{array}$ & $\begin{array}{l}13.10 \\
13.00 \\
12.86 \\
12.84 \\
12.94\end{array}$ & $\begin{array}{ll}\text { July } & 2 \\
\text { Aug. } & 1 \\
\text { Sept. } & 1 \\
\text { Oct. } 2 \\
\text { Dec. } 1\end{array}$ & $\begin{array}{ll}21, & 1950 \\
17 & \\
18 \\
24 \\
12\end{array}$ & $\begin{array}{l}13.10 \\
13.16 \\
13.10 \\
13.09 \\
12.92\end{array}$ \\
\hline
\end{tabular}

4-22-29ad

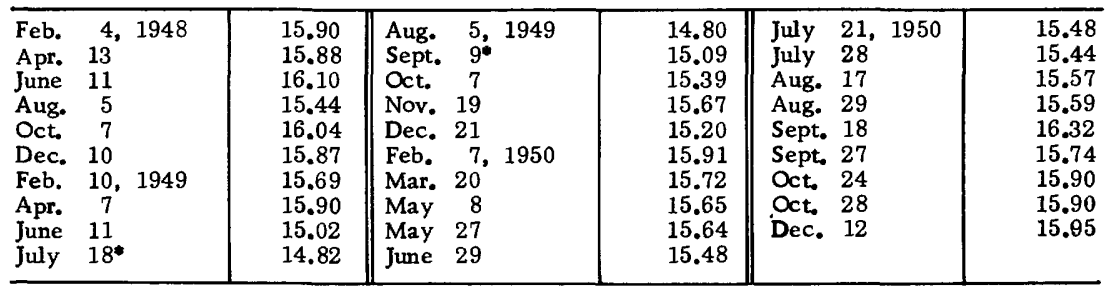

4-22-29da

\begin{tabular}{|c|c|c|c|c|c|c|}
\hline $\begin{array}{l}\text { June } \\
\text { July } \\
\text { Aug. } \\
\text { Sept. } \\
\text { Oct. } \\
\text { Nov. }\end{array}$ & $\begin{array}{c}10, \\
1849 \\
5 \\
9 \\
7 \\
19\end{array}$ & $\begin{array}{l}14.55 \\
14.92 \\
15.26 \\
15.80 \\
15.94 \\
15.82\end{array}$ & $\begin{array}{lrl}\text { Dec. } & 21, & 1949 \\
\text { Feb. } & 7, & 1950 \\
\text { Mar. } & 20 & \\
\text { May } & 8 & \\
\text { Jume } & 23 & \end{array}$ & $\begin{array}{l}15.77 \\
15.63 \\
15.39 \\
15.38 \\
15.49\end{array}$ & 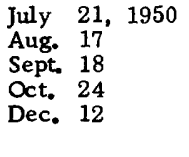 & $\begin{array}{l}15.80 \\
15.91 \\
16.01 \\
16.06 \\
15.92\end{array}$ \\
\hline
\end{tabular}

4-22-30ba

\begin{tabular}{l|l||l|l||l|l|l}
\hline Feb. 7,1950 & 8.15 & Aug. 17, 1950 & 8.45 & Oct. 24, 1950 & 8.70 \\
June 23 & 7.44 & Sept. 18 & 8.76 & Dec. 12 & 8.45 \\
\hline
\end{tabular}


Water-level measurements in wells, in feet below land-surface datum with recorder chart readings of lowest daily water levels in 1950- Continued

\begin{tabular}{l|l||l|l||l|l|l|l}
\hline Date & $\begin{array}{l}\text { Water } \\
\text { level }\end{array}$ & Date & $\begin{array}{l}\text { Water } \\
\text { level }\end{array}$ & $\begin{array}{l}\text { Water } \\
\text { level }\end{array}$ \\
\hline
\end{tabular}

FURNAS COUNTY-Continued

$4-22-32 d d$

\begin{tabular}{|c|c|c|c|c|c|c|}
\hline $\begin{array}{l}\text { Feb. } \\
\text { Apr. } \\
\text { June } \\
\text { Aug. } \\
\text { Oct. } \\
\text { Dec. } \\
\text { Feb. }\end{array}$ & $\begin{array}{ll}2, & 1948 \\
9 & \\
7 & \\
2 & \\
1 & \\
6 & \\
7, & 1949\end{array}$ & $\begin{array}{r}10.03 \\
9.32 \\
10.60 \\
10.09 \\
12.17 \\
12.20 \\
11.89\end{array}$ & $\begin{array}{lrl}\text { Apr. } & 7,1949 \\
\text { June } & 6 & \\
\text { Aug. } & 1 \\
\text { Oct. } & 3 \\
\text { Nov. } & 15 \\
\text { Dec. } & 17\end{array}$ & $\begin{array}{r}8.84 \\
8.15 \\
11.42 \\
11.06 \\
10.35 \\
10.08\end{array}$ & $\begin{array}{lll}\text { Jan. } & 19, & 1950 \\
\text { Mar. } & 17 & \\
\text { May } & 12 \\
\text { June } & 23 \\
\text { July } & 22 \\
\text { Dec. } & 12 & \end{array}$ & $\begin{array}{r}9.82 \\
9.24 \\
9.04 \\
9.61 \\
10.49 \\
10.18\end{array}$ \\
\hline
\end{tabular}

$4-22-33$ aа

\begin{tabular}{l|l||l|l||l|l|l}
\hline Jume 10,1949 & 12.85 & Mar. 20, 1950 & 14.87 & Aug. 17, 1950 & 15.55 \\
July $18^{*}$ & 12.90 & May 8 & 15.03 & Sept. 18 & 15.54 \\
Sept. $9 *$ & 13.60 & June 23 & 14.69 & Oct. 24 & 15.39 \\
Dec. 21 & 14.31 & July 21 & 15.43 & Dec. 12 & 15.13 \\
Feb. 7,1950 & 14.77 & & & & \\
\hline
\end{tabular}

$4-22-34 b b$

\begin{tabular}{l|r||l|l||lr|r}
\hline Feb. 4,1948 & 14.05 & June 10, 1949 & 12.76 & May 8, 1950 & 14.68 \\
Apr. 13 & 13.85 & July $18 *$ & 13.60 & June 23 & 14.52 \\
June 11 & 15.61 & Oct. 7 & 15.40 & July 21 & 15.29 \\
Oct. & 7 & 15.55 & Nov. 19 & 14.65 & Sept. 18 & 15.45 \\
Dec. 10 & 15.23 & Dec. 21 & 14.39 & Oct. 24 & 15.34 \\
Feb. 10,1949 & 14.45 & Feb. 7,1950 & 14.52 & Dec. 12 & 15.03 \\
Apr. 7 & 13.75 & Mar. 20 & 14.57 & & \\
\hline
\end{tabular}

4-22-35bd

\begin{tabular}{l|l||l|l||l|l|}
\hline May 18, 1950 & 2.10 & Aug. 17, 1950 & 2.58 & Oct. 24, 1950 & 3.06 \\
June 23 & 2.84 & Sept. 18 & 2.72 & Dec. 12 & 2.60 \\
July 21 & 2.94 & & & & \\
\hline
\end{tabular}

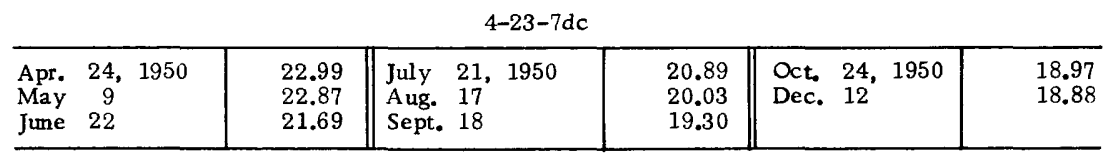

4-23-15da

\begin{tabular}{l|r||rr|r||l|l|}
\hline June & 10,1949 & 39.58 & Jan. 20, 1950 & 39.55 & Aug. 17, 1950 & 39.52 \\
July 18 & 39.22 & Mar. 17 & 39.31 & Sept. 18 & 39.57 \\
Oct. & 7 & 39.42 & May 8 & 39.19 & Oct. 24 & 39.65 \\
Nov. 19 & 39.49 & June 23 & 39.45 & Dec. 12 & 39.68 \\
Dec. 21 & 39.49 & July 21 & 39.50 & & & \\
\hline
\end{tabular}

4-23-15db

\begin{tabular}{l|l||l|l||l|l|}
\hline May 18, 1950 & 32.74 & Sept. 27, 1950** & 32.65 & Nov. 14, 1950** & 32.37 \\
Sept. 11 & 32.72 & Oct. 24 & 32.50 & Dec. 12 & 32.12 \\
Sept. 18 & 32.64 & Oct. 27** & 32.47 & & \\
\hline
\end{tabular}


GROUND-WATER GEOLOCY, REPUBLICAN AND FRENCHMAN VALLEYS, NEBR, 649

Water-level measturements in wells, in feet below land-surfece detum, with reconder chart readings of lowest daily water levels in 1950 - Continued

\begin{tabular}{l|l|l|l|l|l|l|l|l|l|l}
\hline Date & $\begin{array}{l}\text { Water } \\
\text { level }\end{array}$ & Date & Date & $\begin{array}{l}\text { Water } \\
\text { level }\end{array}$ & \\
\hline
\end{tabular}

FURNAS COUNTY-Continued

4-23-17bd

\begin{tabular}{|c|c|c|c|c|c|c|}
\hline $\begin{array}{l}\text { Jume } 1 \\
\text { July } 1 \\
\text { Sept. } \\
\text { Oct. } \\
\text { Nov. } 1\end{array}$ & $\begin{array}{l}10,1949 \\
18 \\
9 \\
7 \\
19\end{array}$ & $\begin{array}{l}28.55 \\
28.50 \\
28.36 \\
28.35 \\
28.31\end{array}$ & $\begin{array}{lrl}\text { Dec. } & 21, & 1949 \\
\text { Jan. } & 20, & 1950 \\
\text { Mar. } & 17 & \\
\text { May } & 9 & \\
\text { June } & 22 & \end{array}$ & $\begin{array}{l}28.79 \\
28.27 \\
28.29 \\
28.34 \\
28.26\end{array}$ & $\begin{array}{l}\text { July } 21,1950 \\
\text { Aug. } 17 \\
\text { Sept. } 18 \\
\text { Oct. } 24 \\
\text { Dec. } 12\end{array}$ & $\begin{array}{l}28.25 \\
28.18 \\
28.12 \\
28.08 \\
27.99\end{array}$ \\
\hline
\end{tabular}

4-23-18ad

\begin{tabular}{|c|c|c|c|c|c|c|}
\hline $\begin{array}{l}\text { Apr, } \\
\text { June } \\
\text { July }\end{array}$ & $\begin{array}{l}24,1950 \\
22 \\
21\end{array}$ & $\begin{array}{l}18.67 \\
17.89 \\
18.03\end{array}$ & $\begin{array}{l}\text { Aug. 21, } 1950 \\
\text { Sept. } 18\end{array}$ & $\begin{array}{l}18.10 \\
18.14\end{array}$ & $\begin{array}{l}\text { Oct. } 24,1950 \\
\text { Dec. } 12\end{array}$ & $\begin{array}{l}18.25 \\
18.37\end{array}$ \\
\hline \multicolumn{7}{|c|}{$4-23-18 c c b$} \\
\hline $\begin{array}{l}\text { Jan. } \\
\text { Jan. } \\
\text { Mar. } \\
\text { May }\end{array}$ & $\begin{array}{l}12,1950^{*} \\
20 \\
17 \\
9\end{array}$ & $\begin{array}{l}11.50 \\
11.55 \\
11.58 \\
11.38\end{array}$ & $\begin{array}{l}\text { June } 22,1950 \\
\text { July } 21 \\
\text { Aug. } 17\end{array}$ & $\begin{array}{l}10.45 \\
10.87 \\
10.95\end{array}$ & $\begin{array}{lll}\text { Sept. } & 18,1950 \\
\text { Oct. } & 18 \\
\text { Dec. } & 12\end{array}$ & $\begin{array}{l}11.12 \\
11.60 \\
11.71\end{array}$ \\
\hline
\end{tabular}

$4-23-18 \mathrm{ccc}$

\begin{tabular}{|c|l|l|ll|l||l|l|}
\hline Jan. 20,1950 & 16.04 & June 22,1950 & 15.17 & Sept. 18, 1950 & 15.97 \\
Mar. 17 & 16.31 & July 20 & & 15.62 & Oct. 24 & 16.41 \\
May 9 & 16.16 & Aug. 17 &. & 15.70 & Dec. 12 & 16.57 \\
\hline
\end{tabular}

$4-23-19 a b$

\begin{tabular}{|l|l||l|l||l|l|l|}
\hline June 22,1950 & 11.65 & Aug. 17, 1950 & 12.73 & Oct. 24, 1950 & 13.59 \\
July 20 & 12.40 & Sept. 18 & 13.21 & Dec. 12 & 13.69 \\
\hline
\end{tabular}

4-23-19ad

\begin{tabular}{|c|c|c|c|c|c|c|}
\hline $\begin{array}{l}\text { Jume } \\
\text { July } \\
\text { Aug. } \\
\text { Sept. } \\
\text { Oct. } \\
\text { Nov. }\end{array}$ & $\begin{array}{l}10,1949 \\
18^{*} \\
5 \\
9 \\
7 \\
19\end{array}$ & $\begin{array}{l}4.12 \\
5.83 \\
6.56 \\
6.85 \\
7.60 \\
7.42\end{array}$ & $\begin{array}{lrl}\text { Dec, } & 21, & 1949 \\
\text { Jan. } & 20,1950 \\
\text { Mar. } & 17 \\
\text { May } & 9 \\
\text { June } & 22\end{array}$ & $\begin{array}{l}7.37 \\
7.23 \\
6.76 \\
6.41 \\
5.75\end{array}$ & $\begin{array}{ll}\text { July } & 21, \\
\text { Aug. } & 17 \\
\text { Sept. } & 18 \\
\text { Oct. } & 24 \\
\text { Dec. } & 12\end{array}$ & $\begin{array}{l}6.67 \\
7.06 \\
7.31 \\
7.64 \\
7.48\end{array}$ \\
\hline
\end{tabular}

4-23-19ba

\begin{tabular}{|l|l||l|r|r||l|l|}
\hline Jan. $12,1950^{*}$ & 10.42 & May & 9,1950 & 10.33 & Sept. 18, 1950 & 12.28 \\
Jan. 20 & 10.50 & Jume 22 & & 9.00 & Oct. 24 & 10.71 \\
Mar. 17 & 10.44 & Aug. 17 & 9.97 & Dec. 12 & 10.87 \\
\hline
\end{tabular}

$4-23-19 b b$

\begin{tabular}{|c|c|c|c|c|c|c|c|}
\hline $\begin{array}{l}\text { Jan. } \\
\text { Mar. } \\
\text { May }\end{array}$ & $\begin{array}{rr}20, & 1950 \\
17 & \\
9 & \end{array}$ & $\begin{array}{l}12.73 \\
12.57 \\
12.56\end{array}$ & $\begin{array}{ll}\text { June } & 2 \\
\text { July } & 2 \\
\text { Aug. } & 1\end{array}$ & $\begin{array}{l}22,1950 \\
17\end{array}$ & $\begin{array}{l}11.46 \\
12.94 \\
12.10\end{array}$ & $\begin{array}{l}\text { Sept. 18, } 1950 \\
\text { Oct. 24 } \\
\text { Dec. } 12\end{array}$ & $\begin{array}{r}12.50 \\
12.92 \\
13.02\end{array}$ \\
\hline
\end{tabular}


Water-level measurements in wells, in feot below land-surface datum, with recorder chart reading s' of lowest daity water levels in 1950-Continued

\begin{tabular}{c|c||l|l||l|l|}
\hline Date & $\begin{array}{l}\text { Water } \\
\text { level }\end{array}$ & Date & $\begin{array}{l}\text { Water } \\
\text { level }\end{array}$ & Date & $\begin{array}{l}\text { Water } \\
\text { level }\end{array}$ \\
\hline
\end{tabular}

FURNAS COUNTY-Cọntinued

$4-23-19 b c$

\begin{tabular}{l|l|l|l|l|l|l|l|l}
\hline Jan. 20,1950 & 9.20 & Jume 22,1950 & 8.17 & Sept, 18, 1950 & 9.28 \\
Mar. 17 & 8.80 & July 21 & 8.76 & Oct. 24 & 9.59 \\
May 9 & 8.70 & Aug. 17 & 8.94 & Dec. 12 & 9.53 \\
\hline
\end{tabular}

$4-23-20 \mathrm{ab}$

\begin{tabular}{|c|c|c|c|c|c|c|}
\hline $\begin{array}{lrl}\text { Feb. } & 4, & 1948 \\
\text { Apr. } & 13 & \\
\text { Jume } & 11 & \\
\text { Oct. } & 7 & \\
\text { Dec. } & 10 & \\
\text { Feb. } & 10, & 1949 \\
\text { Apr. } & 4 & \end{array}$ & $\begin{array}{l}27.19 \\
27.21 \\
28.28 \\
27.59 \\
27.82 \\
27.62 \\
27.22\end{array}$ & $\begin{array}{lrr}\text { Jume } & 10, & 1949 \\
\text { July } & 18^{\star} & \\
\text { Sept. } & 9 & \\
\text { Oct. } & 7 & \\
\text { Nov. } & 19 & \\
\text { Dec. } & 21 & \\
\text { Jan. } & 20, & 1950\end{array}$ & $\begin{array}{l}26.32 \\
.26 .42 \\
27.68 \\
27.52 \\
27.58 \\
27.52 \\
27.73\end{array}$ & $\begin{array}{l}\text { Mar. } 1 \\
\text { May } \\
\text { June } 2 \\
\text { July } 2 \\
\text { Sept. } 1 \\
\text { Oct. } 2 \\
\text { Dec. } 1\end{array}$ & $\begin{array}{ll}16, & 1950 \\
9 & \\
22 & \\
21 & \\
18 & \\
24 & \\
12 & \end{array}$ & $\begin{array}{l}27.77 \\
27.78 \\
26.95 \\
28.07 \\
28.27 \\
27.80 \\
27.67\end{array}$ \\
\hline
\end{tabular}

$4-23-20 b b$

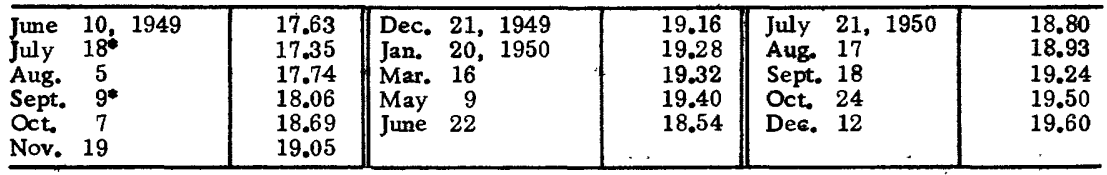

4-23-21ad

\begin{tabular}{ll|l||ll|l||l|l|}
\hline Jan. 12, 1950* & 29.36 & June 22,1950 & 28.95 & Sept. 18, 1950 & 29.54 \\
Jan 20 & 29.37 & July 21 & 29.17 & Oct. 24 & 29.61 \\
Mar. 17 & 29.28 & Aug. 17 & 29.24 & Dec. 12 & 29.63 \\
\hline
\end{tabular}

4-23-22dc

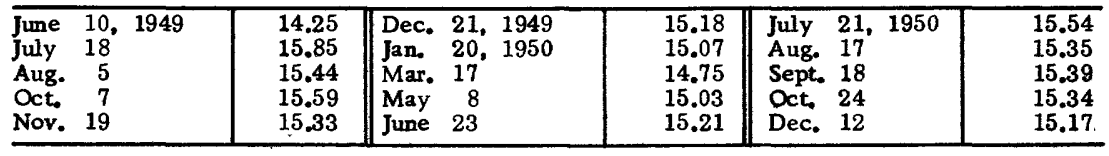

4-23-23bd

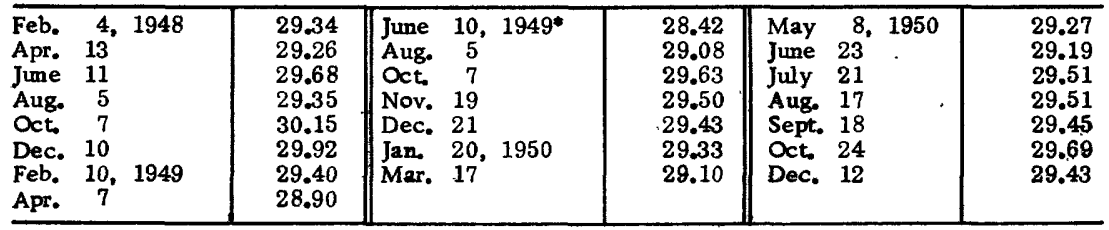

4-23-24bc

\begin{tabular}{l|l|l|ll|l|l|l|l}
\hline Jan. 12, 1950 & 14.60 & Jume 23,1950 & 15.00 & Sept. 18, 1950 & 14.94 \\
Feb. 7 & & 14.32 & July 21 & 15.04 & Oct. 24 & 15.28 \\
Mar. 20 & 14.40 & Aug. 17 & 14.95 & Dec. 12 & 14.74 \\
May 8 & 14.63 & & & & & \\
\hline
\end{tabular}


GROUND-WATER GEOLOGY, REPUBLICAN AND FRENCHMAN VALLEYS, NEBR. 651

Water-level measurements in wells, in feet below landsurface datum, with recorder chart readings of lowest daily water levels in 1950-Continued

\begin{tabular}{c|c|c|c||c|c|c|}
\hline Date & $\begin{array}{l}\text { Water } \\
\text { level }\end{array}$ & Date & $\begin{array}{l}\text { Water } \\
\text { level }\end{array}$ & $\begin{array}{l}\text { Water } \\
\text { level }\end{array}$ \\
\hline
\end{tabular}

FURNAS COUNTY-Continued

4-23-24bd

\begin{tabular}{l|l|l|l|l|l|l|l|l}
\hline Jan. 12, 1950 & 8.44 & May 8,1950 & 7.82 & Sept. 18, 1950 & 8.85 \\
Feb. 7 & 8.38 & June 23 & & 6.61 & Oct. 24 & 9.08 \\
Mar. 20 & 7.89 & July 21 & 7.92 & Dec. 12 & 8.89 \\
\hline
\end{tabular}

4-23-25aa

\begin{tabular}{l|l||l|l||l|l|l}
\hline Dec. 16, 1949 & 7.72 \\
Feb. June 23, 1950 & 7,1950 & 7.43 & July 21 & 6.90 & Sept. 18, 1950 & 8.04 \\
Mar. 20 & 7.13 & Aug. 17 & 7.59 & Oct. 24 & 8.01 \\
May 8 & 7.05 & & 7.76 & Dec. 12 & 7.76 \\
\hline
\end{tabular}

$4-23-27 b b$

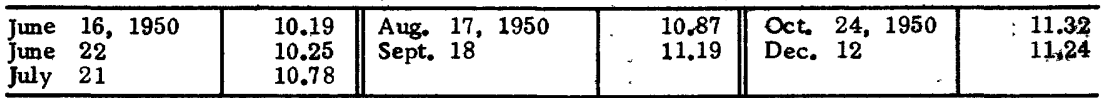

4-23-27dd

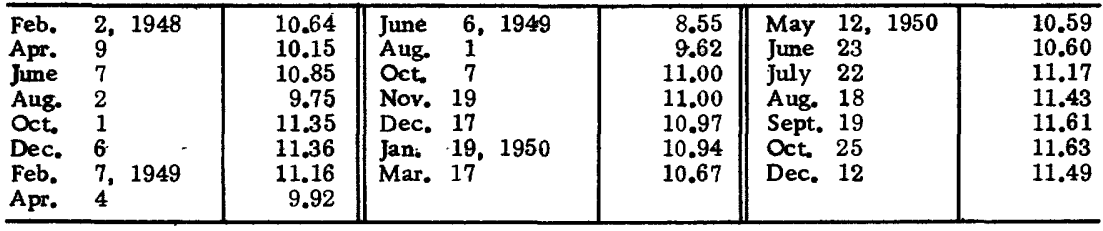

4-23-30cc

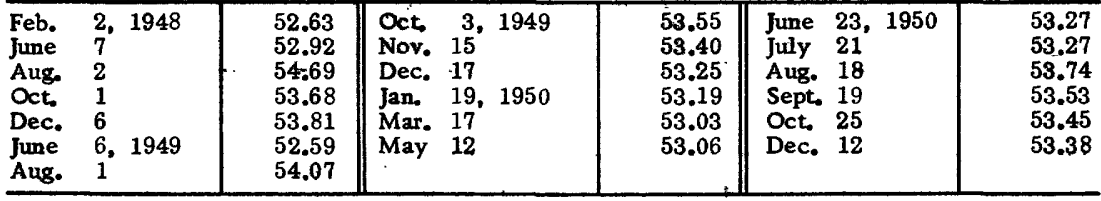

4-23-36az

\begin{tabular}{ll|l||ll|l||ll|l}
\hline Feb. & 2,1948 & 20.45 & June & 6,1949 & 17.43 & May 12,1950 & 19.65 \\
Apr. & 9 & 20.12 & Aug. & 1 & 18.53 & June 23 & & 19.40 \\
Jume & 7 & 20.59 & Oct. & 3 & 19.96 & July 22 & 19.88 \\
Aug. & 2 & 19.04 & Nov. 15 & 20.17 & Aug. 18 & 20.10 \\
Oct. & 1 & 20.52 & Dec. 17 & 20.10 & Sept. 19 & 20.41 \\
Dec. & 6 & 20.82 & Jan. 19,1950 & 20.08 & Oct. 25 & 20.45 \\
Feb. & 7,1949 & 20.51 & Mar. 17 & 19.82 & Dec. 12 & 20.35 \\
Apr. & 7 & 20.07 & & & & & \\
\hline
\end{tabular}

4-24-13aa

\begin{tabular}{l|l|l|l|l||l|l|}
\hline Jan. 12, 1950* & 25.62 & June 22, 1950 & 25.07 & Sept. 18, 1950 & 24.09 \\
Jan. 20 & 25.73 & July 20 & 24.75 & Oct. 24 & 23.91 \\
Mar. 17 & 25.84 & Aug. 17 & 24.45 & Dec. 12 & 23.88 \\
May 9 & 25.81 & & & & & \\
\hline
\end{tabular}


Water-level measurements in wells, in feet below land-surface datum, with recorder chart readings of lowest daily water levels in 1950-Continued

\begin{tabular}{l|l|l|l|l|l|l|l|l}
\hline Date & $\begin{array}{l}\text { Water } \\
\text { level }\end{array}$ & Date & $\begin{array}{l}\text { Water } \\
\text { level }\end{array}$ & Date \\
\hline
\end{tabular}

FURNAS COUNTY-Continued

4-24-13bb

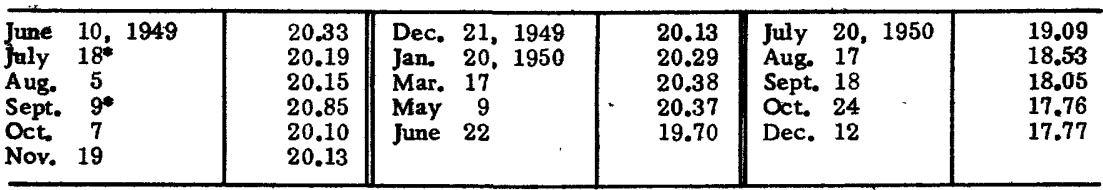

4-24-13cd

\begin{tabular}{|c|c|c|c|c|c|c|c|}
\hline $\begin{array}{lrl}\text { Feb. } & 4, & 1948 \\
\text { Apr. } & 13 & \\
\text { Jume } & 11 & \\
\text { Aug. } & 5 & \\
\text { Oct. } & 7 & \\
\text { Dec. } & 10 & \\
\text { Feb. } & 10, & 1949\end{array}$ & $\begin{array}{l}17.52 \\
17.64 \\
18.04 \\
16.65 \\
17.12 \\
17.55 \\
17.79\end{array}$ & $\begin{array}{l}\text { Apr. } \\
\text { June } 1 \\
\text { July } 1 \\
\text { Aug. } \\
\text { Oct. } \\
\text { Nov. } 1 \\
\text { Dec. } 2\end{array}$ & $\begin{array}{l}4,1949 \\
10 \\
18 * \\
5 \\
7 \\
19 \\
21\end{array}$ & $\begin{array}{l}17.15 \\
16.62 \\
16.26 \\
16.45 \\
16.90 \\
17.42 \\
17.50\end{array}$ & $\begin{array}{ll}\text { Jan. } & 2 \\
\text { Mar. } & 1 \\
\text { May } & \\
\text { June } & 2 \\
\text { July } & 2 \\
\text { Oct. } & 2 \\
\text { Dec. } & 1\end{array}$ & $\begin{aligned} 20, & 1950 \\
17 & \\
9 & \\
22 & \\
20 & \\
24 & \\
12 & \end{aligned}$ & $\begin{array}{l}17.59 \\
17.75 \\
17.62 \\
16.88 \\
17.08 \\
17.57 \\
18.58\end{array}$ \\
\hline
\end{tabular}

4-24-14cb

\begin{tabular}{|c|c|c|c|c|c|c|}
\hline $\begin{array}{lc}\text { June } & 10,1949 \\
\text { July } & 18^{*} \\
\text { Aug. } & 6 \\
\text { Sept. } & 9^{*} \\
\text { Oct. } & 7 \\
\text { Nov. } & 19\end{array}$ & $\begin{array}{l}20.73 \\
21.28 \\
22.34 \\
22.50 \\
22.77 \\
23.02\end{array}$ & $\begin{array}{ll}\text { Dec. } & 2 \\
\text { Jan. } & 2 \\
\text { Mar. } & 1 \\
\text { May } & \\
\text { June } 2\end{array}$ & $\begin{array}{rr}21, & 1949 \\
20, & 1950 \\
16 & \\
9 & \\
22 & \end{array}$ & $\begin{array}{l}23.07 \\
23.25 \\
23.33 \\
23.62 \\
20.94\end{array}$ & $\begin{array}{l}\text { July } 20,1850 \\
\text { Aug. } 17: \\
\text { Sept. } 18 \\
\text { Oct. } 24 \\
\text { Dec. } 12\end{array}$ & $\begin{array}{l}20.65 \\
20.50 \\
20.29 \\
20.42 \\
20.74\end{array}$ \\
\hline
\end{tabular}

4-24-14cc

\begin{tabular}{ll|l||l|l|l|l|l}
\hline June & 10,1949 & 21.50 & Nov. 19, 1949 & 22.68 & Aug. 17, 1950 & 22.30 \\
July & $18 *$ & 21.44 & Dec. 21 & 22.76 & Sept. 18 & 22.30 \\
Aug. & 5 & 21.90 & Mar. 16, 1950 & 21.48 & Oct. 24. & 22.69 \\
Sept. & $9 *$ & 22.50 & Jume 22 & 21.98 & Dec. 12 & 22.46 \\
Oct. & 7 & 22.80 & July 20 & 22.45 & & \\
\hline
\end{tabular}

4-24-14da

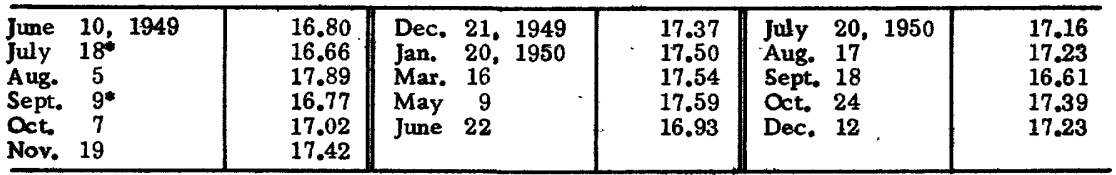

4-24-15cb

\begin{tabular}{|c|c|c|c|c|c|}
\hline $\begin{array}{lc}\text { June } & 10,1949 \\
\text { July } & 18^{*} \\
\text { Aug. } & 5 \\
\text { Sept. } & 9^{*} \\
\text { Oct. } & 7 \\
\text { Nov. } & 18\end{array}$ & $\begin{array}{l}15.18 \\
14.88 \\
15.00 \\
15.03 \\
15.46 \\
15.78\end{array}$ & $\begin{array}{lrl}\text { Dec. } & 21, & 1949 \\
\text { Jan. } & 20, & 1950 \\
\text { Mar. } & 16 & \\
\text { May } & 9 & \\
\text { June } & 21 & \end{array}$ & $\begin{array}{l}15.93 \\
16.00 \\
15.85 \\
14.50 \\
12.70\end{array}$ & $\begin{array}{ll}\text { July } 20,1950 \\
\text { Aug. } 21 \\
\text { Sept. } 19 \\
\text { Oct. } 19 \\
\text { Dec. } 12\end{array}$ & $\begin{array}{l}12.37 \\
11.90 \\
11.37 \\
12.27 \\
13.38\end{array}$ \\
\hline
\end{tabular}

$4-24-15 c c$

\begin{tabular}{l|l||lc|l|l|l|l}
\hline Feb. & 4,1948 & 13.37 & June & 10,1948 & 13.55 & Oct. 7,1948 & 13.33 \\
Apr. & 13 & 12.97 & Aug. & 5 & 12.14 & Dec. 10 & 13.70
\end{tabular}


GROUND-WATER GEOLOGY, REPUBLICAN AND FRENCHMAN VALLEYS, NEBR. 653

Water-level measurements in wells, in feet below land-surface datum, with recorder chart readings of lowest daily water levels in 1950-Continued

\begin{tabular}{c|l|l|l|l|l|l|l}
\hline Date & $\begin{array}{l}\text { Water } \\
\text { level }\end{array}$ & Date & $\begin{array}{l}\text { Water } \\
\text { level }\end{array}$ & $\begin{array}{l}\text { Water } \\
\text { level }\end{array}$ \\
\hline
\end{tabular}

FURNAS COUNTY-Continued

4-24-15cc-Continued

\begin{tabular}{|c|c|c|c|c|c|c|c|}
\hline $\begin{array}{lrl}\text { Feb. } & 10, & 1949 \\
\text { Apr. } & 4 \\
\text { Apr. } & 21 \\
\text { June } & 10 \\
\text { July } & 18 \\
\text { Aug. } & 5\end{array}$ & $\begin{array}{l}13.50 \\
12.52 \\
12.35 \\
11.44 \\
11.86 \\
12.35\end{array}$ & $\begin{array}{lr}\text { Oct. } & 7, \\
\text { Nov. } & 18 \\
\text { Dec. } & 21 \\
\text { Jan. } & 20, \\
\text { Mar. } & 16 \\
\text { May } & 9\end{array}$ & $\begin{array}{l}1949 \\
1950\end{array}$ & $\begin{array}{l}13.16 \\
13.35 \\
13.33 \\
13.28 \\
13.08 \\
12.61\end{array}$ & $\begin{array}{l}\text { June } \\
\text { July } \\
\text { Aug. } \\
\text { Sept. } \\
\text { Oct. } \\
\text { Dec. }\end{array}$ & $\begin{array}{ll}21, & 1950 \\
20 & \\
21 & \\
19 \\
19 \\
12\end{array}$ & $\begin{array}{l}11.45 \\
11.74 \\
11.64 \\
11.55 \\
11.71 \\
12.12\end{array}$ \\
\hline
\end{tabular}

4-24-17cc

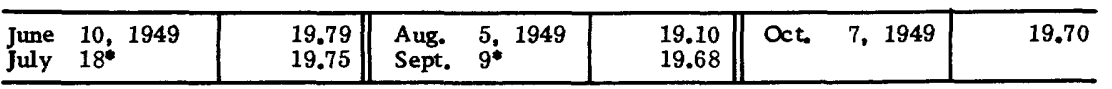

$4-24-19 \mathrm{cb}$

\begin{tabular}{|c|c|c|c|c|c|}
\hline 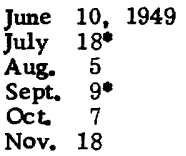 & $\begin{array}{l}12.32 \\
12.25 \\
13.10 \\
13.09 \\
13.52 \\
14.02\end{array}$ & $\begin{array}{lrl}\text { Dec. } & 20,1949 \\
\text { Jan. } & 20,1950 \\
\text { Mar. } & 16 \\
\text { May } & 9 & \\
\text { June } & 21 & \end{array}$ & $\begin{array}{l}13.96 \\
13.97 \\
13.71 \\
11.10 \\
10.55\end{array}$ & $\begin{array}{lr}\text { July } & 20,1950 \\
\text { Aug. } & 21 \\
\text { Sept. } & 19 \\
\text { Oct. } & 19 \\
\text { Dec. } & 6\end{array}$ & $\begin{array}{l}10.71 \\
13.03 \\
12.67 \\
13.12 \\
13.16\end{array}$ \\
\hline
\end{tabular}

4-24-19cd

\begin{tabular}{lr|r||l|l||l|l|l}
\hline Feb. 4,1948 & 14.26 & June 10,1949 & 11.77 & May 9, 1950 & 12.22 \\
Apr. 13 & 13.76 & July $18^{*}$ & 12.67 & Jume 21 & 11.51 \\
June 10 & 14.59 & Aug. 5 & 15.12 & July 20 & 12.36 \\
Aug. 5 & 14.16 & Oct. 7 & 13.90 & Aug. 21 & 12.80 \\
Oct. & 7 & 14.40 & Nov. 18 & 14.22 & Sept. 19 & 13.33 \\
Dec. 10 & 14.40 & Dec. 20 & 14.02 & Oct. 19 & 13.22 \\
Feb. 10, 1949 & 13.80 & Jan. 20, 1950 & 13.80 & Dec. 6 & 13.50 \\
Apr. 4 & 13.04 & Mar. 16 & 13.08 & & \\
\hline
\end{tabular}

4-24-19da

\begin{tabular}{l|l||l|l||l|l|l|}
\hline Apr. 24, 1950 & 6.89 & July 20, 1950 & 6.11 & Oct. 19, 1950 & 6.74 \\
May 9 & 6.29 & Aug. 21 & 6.30 & Dec. 6 & \\
June 21 & 5.61 & Sept. 19 & 6.59 & & \\
\hline
\end{tabular}

4-24-20ca

\begin{tabular}{l|l|l|l|l||lc|r}
\hline Apr. 24, 1950 & 5.34 & July 20, 1950 & 5.34 & Oct. 19, 1950 & 5.64 \\
May 9 & 5.00 & Aug. 21 & 5.62 & Dec. 6 & \\
June 21 & 4.76 & Sept. 19 & 5.58 & & & \\
\hline
\end{tabular}

4-24-20cbb

\begin{tabular}{l|r||l|r||l|l}
\hline June 10,1949 & 3.29 & Dec. 20, 1949 & 6.74 & July 20, 1950 & 5.82 \\
July $18^{*}$ & 5.82 & Jan. 20, 1950 & 6.66 & Aug. 21 & 6.00 \\
Aug. 5 & 6.16 & Mar. 16 & 6.45 & Sept. 19 & 6.21 \\
Sept. 9* & 6.55 & May 9 & 5.98 & Oct. 19 & 6.41 \\
Oct. 7 & 6.94 & June 21 & 5.34 & Dec. 6 & 6.23 \\
Nov. 18 & 6.83 & & & & \\
\hline
\end{tabular}


Water-1evel measurements in wells, in feet below land-surface datum, with recorder chart readings of lowest daily water levels in 1950-Continued

\begin{tabular}{l|l|l|l||l|l|l|l|l|l|}
\hline Date & $\begin{array}{l}\text { Water } \\
\text { level }\end{array}$ & Date & $\begin{array}{l}\text { Water } \\
\text { level }\end{array}$ & $\begin{array}{l}\text { Dater } \\
\text { level }\end{array}$ \\
\hline
\end{tabular}

FURNAS COUNTY-Continued

$4-24-20 c b c$

\begin{tabular}{|c|c|c|c|c|c|c|}
\hline $\begin{array}{lc}\text { June } & 10,1949 \\
\text { July } & 18^{\circ} \\
\text { Aug. } & 5 \\
\text { Oct. } & 7 \\
\text { Nov. } & 18\end{array}$ & $\begin{array}{l}4.54 \\
6.01 \\
6.44 \\
6.42 \\
6.15\end{array}$ & $\begin{array}{l}\text { Dec. } \\
\text { Jan. } \\
\text { Mar. } \\
\text { May } \\
\text { June } 2\end{array}$ & $\begin{array}{rr}20, & 1949 \\
20, & 1950 \\
16 & \\
9 & \\
21 & \end{array}$ & $\begin{array}{l}5.99 \\
5.86 \\
5.58 \\
5.64 \\
5.66\end{array}$ & $\begin{array}{lr}\text { July } & 20,1950 \\
\text { Aug. } & 21 \\
\text { Sept. } & 19 \\
\text { Oct. } & 19 \\
\text { Dec. } & 6\end{array}$ & $\begin{array}{l}5.93 \\
5.97 \\
6.08 \\
6.07 \\
5.88\end{array}$ \\
\hline
\end{tabular}

4-24-20cc

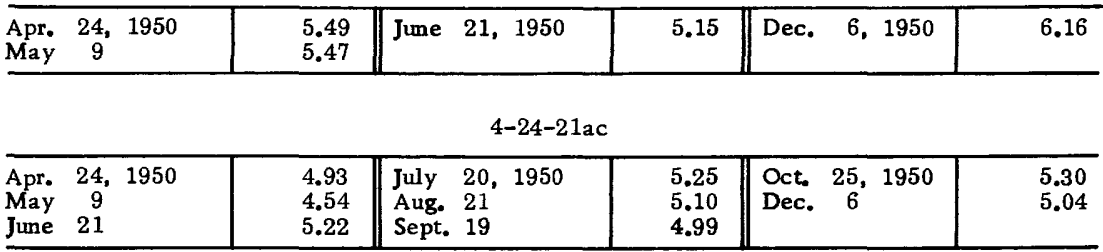

4-24-21ad

\begin{tabular}{l|l|r||ll|l||l|r|r}
\hline Dec. $16,1949^{*}$ & 5.00 & June 21,1950 & 4.87 & Sept. 19, & 1950 & \\
Jan. 20 & 4.80 & July 20 & 5.10 \\
Mar. 16 & 4.64 & Aug. 21 & & 5.04 & Oct. & 25 & 5.15 \\
May 9 & 4.55 & & & & & & \\
\hline
\end{tabular}

4-24-21bc

\begin{tabular}{l|l|l|l|l||l|l|l}
\hline Apr. 24, 1950 & 7.91 & July 20, 1950 & 8.43 & Oct. 19, 1950 & 8.61 \\
May 9 & 7.64 & Aug. 21 & 8.36 & Dec. 6 & 8.01 \\
June 21 & 7.66 & Sept. 19 & 8.35 & & & \\
\hline
\end{tabular}

4-24-21da

\begin{tabular}{l|l||l|l||l|l|}
\hline Dec. 16, 1949 & 5.88 & June 21, 1950 & 6.17 & Sept. 19, 1950 & 6.15 \\
Jan. 20, 1950 & 5.57 & July 20 & 6.31 & Oct. 25 & 6.28 \\
Mar. 16 & 5.46 & Aug. 21 & 6.16 & Dec. 6 & 5.92 \\
May 9 & 5.55 & & & & \\
\hline
\end{tabular}

4-24-22bb

\begin{tabular}{|c|c|c|c|c|c|}
\hline 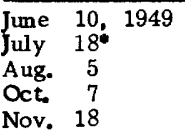 & $\begin{array}{r}7.15 \\
8.97 \\
10.33 \\
10.22 \\
10.02\end{array}$ & $\begin{array}{lrr}\text { Dec. } & 21, & 1949 \\
\text { Jan. } & 20, & 1950 \\
\text { Mar. } & 16 & \\
\text { May } & 9 & \\
\text { June } & 21 & \end{array}$ & $\begin{array}{l}9.88 \\
9.75 \\
9.48 \\
9.38 \\
8.93\end{array}$ & $\begin{array}{lrl}\text { July } & 20, & 1950 \\
\text { Aug. } & 21 & \\
\text { Sept. } & 19 & \\
\text { Oct. } & 25 & \\
\text { Dec. } & 6 & \end{array}$ & $\begin{array}{l}9.51 \\
9.27 \\
9.38 \\
9.46 \\
9.43\end{array}$ \\
\hline
\end{tabular}

4-24-22dd2

\begin{tabular}{|l|l||l|l||l|l|l}
\hline Jume & 9,1950 & 6.30 & Aug. 17, 1950 & 6.60 & Oct. 18, 1950 & 8.01 \\
July 22 & 8.14 & Sept. 17 & 7.71 & Dec. 5 & 7.75 \\
\hline
\end{tabular}

4-24-23aа

\begin{tabular}{ll|l||l|l||l|l|l}
\hline June & 10,1949 & 14.79 & Aug. & 5,1949 & 16.95 & Oct. 7,1949 & 17.00 \\
July $18 *$ & $\mathbf{1 5 . 6 2}$ & Sept. & $9 *$ & & 16.42 & Nov. 19 & 16.75
\end{tabular}


GROUND-WATER GEOLOGY, REPUBLICAN AND FRENCHMAN VALLEYS, NEBR. 655

Water-level measurements in wells, in feet below land-surface datum, with recorder chart readings of lowest daily water levels in 1950 - Continued

\begin{tabular}{l|l|l|l||l|l|l|l}
\hline Date & $\begin{array}{l}\text { Water } \\
\text { level }\end{array}$ & Date & $\begin{array}{l}\text { Water } \\
\text { level }\end{array}$ & $\begin{array}{l}\text { Water } \\
\text { level }\end{array}$ \\
\hline
\end{tabular}

FURNAS COUNTY-Continued

4-24-23aa-Continued

\begin{tabular}{l|l|l||ll|l||l|l|l|}
\hline Dec. 21, 1949 & 16.69 & June 22,1950 & 15.72 & Sept. 18, 1950 & 16.82 \\
Jan. 20, 1950 & 16.56 & July 20 & & 16.49 & Oct. 24 & 16.96 \\
Mar. 17 & 16.18 & Aug. 17 & 16.53 & Dec. 12 & 16.73 \\
May 9 & 16.32 & & & & & & \\
\hline
\end{tabular}

4-24-23bc

\begin{tabular}{l|r|r||l|l||l|l}
\hline June & 10,1949 & 16.22 & Dec. 21, 1949 & 17.79 & July 20, 1950 & 18.17 \\
July $18^{*}$ & 17.80 & Jan. 20, 1950 & 17.49 & Aug. 17 & 17.84 \\
Aug. & 5 & 18.57 & Mar. 16 & 17.30 & Sept. 18 & 17.97 \\
Oct. & 7 & 18.47 & May 9 & 17.43 & Oct. 24 & 18.31 \\
Nov. 19 & 17.93 & Jume 22 & 18.02 & Dec. 12 & 17.87 \\
\hline
\end{tabular}

4-24-24bc

\begin{tabular}{l|l|l|l|l||l|l|}
\hline Dec. 16, 1949 & 6.80 & Jume 22, 1950 & 6.02 & Sept. 18, 1950 & 7.05 \\
Jan. 20, 1950 & 6.65 & July 20 & 6.82 & Oct. 24 & 7.13 \\
Mar. 17 & 6.29 & Aug. 17 & 6.75 & Dec. 12 & 6.87 \\
May 9 & 6.30 & & & & & \\
\hline
\end{tabular}

4-24-29cd

\begin{tabular}{|c|c|c|c|c|c|c|}
\hline $\begin{array}{l}\text { Feb. } \\
\text { Apr. } \\
\text { June } \\
\text { Aug. } \\
\text { Oct. } \\
\text { Dec. } \\
\text { Feb. } \\
\text { Apr. }\end{array}$ & $\begin{array}{ll}2, & 1948 \\
9 & \\
7 & \\
2 & \\
1 & \\
6 & \\
7, & 1949 \\
7 & \end{array}$ & $\begin{array}{l}21.08 \\
20.86 \\
21.40 \\
21.60 \\
22.00 \\
21.35 \\
20.97 \\
20.60\end{array}$ & $\begin{array}{lrl}\text { June } & 6, & 1949 \\
\text { Aug. } & 1 & \\
\text { Oct. } & 3 & \\
\text { Nov. } & 15 & \\
\text { Dec. } & 17 & \\
\text { Jan. } & 19, & 1950 \\
\text { Mar. } & 16 & \end{array}$ & $\begin{array}{l}20.13 \\
21.26 \\
21.03 \\
20.80 \\
20.68 \\
20.54 \\
20.40\end{array}$ & 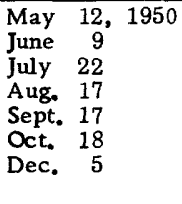 & $\begin{array}{l}20.47 \\
20.11 \\
21.72 \\
21.55 \\
20.91 \\
21.00 \\
20.86\end{array}$ \\
\hline
\end{tabular}

4-24-29da

\begin{tabular}{|c|c|c|c|c|c|}
\hline $\begin{array}{l}\text { June }_{\text {July }} 9,1950 \\
22\end{array}$ & $\begin{array}{l}6.42 \\
7.50\end{array}$ & $\begin{array}{ll}\text { Aug. } & 17,1950 \\
\text { Sept. } & 17\end{array}$ & $\begin{array}{l}7.15 \\
7.75\end{array}$ & $\begin{array}{lcl}\text { Oct. } & 18, & 1950 \\
\text { Dec. } & 5\end{array}$ & $\begin{array}{l}8.18 \\
7.84\end{array}$ \\
\hline
\end{tabular}

4-24-30dd

\begin{tabular}{|l|l||l|l||l|l|l}
\hline June & 9,1950 & 11.23 & Aug. 17, 1950 & 11.47 & Oct. 18, 1950 & 11.49 \\
July 22 & 11.45 & Sept. 17 & 11.45 & Dec. 5 & 11.50 \\
\hline
\end{tabular}

4-24-32bc

\begin{tabular}{|c|c|c|c|c|c|c|}
\hline $\begin{array}{l}\text { June } \\
\text { Aug. }\end{array}$ & $\begin{array}{r}9,1950 \\
17\end{array}$ & $\begin{array}{l}25.29 \\
26.35\end{array}$ & $\begin{array}{ll}\text { Sept, } & 17,1950 \\
\text { Oct. } & 18\end{array}$ & $\begin{array}{l}25.85 \\
26.26\end{array}$ & Dec. 5,1950 & 25.80 \\
\hline \multicolumn{7}{|c|}{$4-25-25 a b$} \\
\hline $\begin{array}{l}\text { Apr. } \\
\text { May } \\
\text { June }\end{array}$ & $\begin{aligned} 24, & 1950 \\
9 & \\
21 & \end{aligned}$ & $\begin{array}{l}4.32 \\
5.42 \\
3.25\end{array}$ & $\begin{array}{lll}\text { July } & 20, & 1950 \\
\text { Aug. } & 21 & \\
\text { Sept. } & 19 & \end{array}$ & $\begin{array}{l}4.19 \\
4.74 \\
5.21\end{array}$ & $\begin{array}{lrl}\text { Oct. } & 19, & 1950 \\
\text { Dec. } & 6\end{array}$ & $\begin{array}{l}5.79 \\
5.46\end{array}$ \\
\hline
\end{tabular}


Water-level measurements in wells, in feet below land-surface datum, with recorder chart readings of lowest daily water levels in 19.50- Continued

\begin{tabular}{c|c||l|l||l|l}
\hline Date & $\begin{array}{l}\text { Water } \\
\text { level }\end{array}$ & Date & $\begin{array}{l}\text { Water } \\
\text { le:vel }\end{array}$ & Date & $\begin{array}{l}\text { Water } \\
\text { level }\end{array}$ \\
\hline
\end{tabular}

\section{FURNAS COUNTY-Continued}

$4-25-25$ ac

\begin{tabular}{l|l|l|l|l||l|l|l}
\hline Apr. 24, 1950 & 4.28 & Aug. 21, 1950 & 5.04 & Oct. 19, 1950 & 5.47 \\
June 21 & 4.09 & Sept. 19 & 5.30 & Dec. 6 & 5.07 \\
July 20 & 4.92 & & & & & \\
\hline
\end{tabular}

4-25-26ada

\begin{tabular}{l|l||l|l||lr|r}
\hline Apr. 24, 1950 & 6.34 & July 20, 1950 & 6.47 & Oct. 19, 1950 & 7.49 \\
May 9 & 5.93 & Aug. 21 & 6.98 & Dec. 6 & 7.23 \\
June 21 & 5.31 & Sept. 19 & 7.33 & & & \\
\hline
\end{tabular}

4-25-26add

\begin{tabular}{l|c|r||ll|l||lr|r}
\hline Apr. 24,1950 & 6.00 & July 20,1950 & 6.72 & Oct. & 19,1950 & & 6.95 \\
May 9 & 5.62 & Aug. 21 & 6.59 & Dec. & 6 & & 6.51 \\
June 21 & 5.89 & Sept. 19 & 6.74 & & & \\
\hline
\end{tabular}

4-25-27adc

\begin{tabular}{|c|c|c|c|c|c|c|c|}
\hline $\begin{array}{lrl}\text { Dec. } & 7,1948^{*} \\
\text { Jan. } & 7,1949^{*} \\
\text { Feb. } & 3^{*} \\
\text { Apr. } & 7^{*} \\
\text { Jume } & 6^{*} \\
\text { July } & 18^{*} \\
\text { Aug. } & 5\end{array}$ & $\begin{array}{l}7.85 \\
9.85 \\
9.71 \\
7.72 \\
6.90 \\
7.33 \\
8.00\end{array}$ & $\begin{array}{l}\text { Sept. } \\
\text { Oct. } \\
\text { Nov. } 18 \\
\text { Dec. } 20 \\
\text { Jan. } 20 \\
\text { Mar. } 16 \\
\text { May }\end{array}$ & $\begin{array}{ll}9, & 1949 \\
7 & \\
8 & \\
0 & \\
0, & 1950 \\
6 & \\
9 & \end{array}$ & $\begin{array}{r}9.30 \\
9.90 \\
10.25 \\
10.42 \\
10.57 \\
10.64 \\
10.26\end{array}$ & $\begin{array}{ll}\text { June } & 2 \\
\text { July } & 2 \\
\text { Aug. } & 2 \\
\text { Sept. } & 1 \\
\text { Oct. } & 1 \\
\text { Dec. } & \end{array}$ & $\begin{array}{ll}21, & 1950 \\
20 & \\
21 & \\
19 \\
19 \\
6\end{array}$ & $\begin{array}{l}10.06 \\
10.59 \\
10.70 \\
10.91 \\
11.11 \\
11.16\end{array}$ \\
\hline
\end{tabular}

4-25-27add

\begin{tabular}{|c|c|c|c|c|c|}
\hline $\begin{array}{ll}\text { Dec. } & 7,1948^{\star} \\
\text { Jan. } & 7,1949^{\star} \\
\text { Feb. } & 3^{\star} \\
\text { Apr. } & 7^{\star} \\
\text { June } & 6^{*} \\
\text { July } & 18^{\star} \\
\text { Sept. } & 9^{\bullet}\end{array}$ & $\begin{array}{l}6.44 \\
6.49 \\
6.47 \\
4.39 \\
3.40 \\
4.56 \\
7.28\end{array}$ & $\begin{array}{lrl}\text { Oct. } & 7, & 1949 \\
\text { Nov. } & 18 & \\
\text { Dec. } & 20 & \\
\text { Jan. } & 20, & 1950 \\
\text { Mar. } & 16 & \\
\text { May } & 9 & \end{array}$ & $\begin{array}{l}7.65 \\
7.80 \\
7.94 \\
8.08 \\
8.08 \\
7.80\end{array}$ & $\begin{array}{lr}\text { June } & 21,1950 \\
\text { July } & 20 \\
\text { Aug. } & 21 \\
\text { Sept. } & 19 \\
\text { Oct. } & 19 \\
\text { Dec. } & 6\end{array}$ & $\begin{array}{l}7.34 \\
8.11 \\
8.09 \\
8.26 \\
8.42 \\
8.42\end{array}$ \\
\hline
\end{tabular}

4-25-27daa 1

\begin{tabular}{|c|c|c|c|c|c|}
\hline $\begin{array}{ll}\text { Dec. } & 7,1948^{\star} \\
\text { Jan. } & 7,1949^{\star} \\
\text { Feb. } & 3^{\star} \\
\text { Apr. } & 7^{\star} \\
\text { June } & 6^{*} \\
\text { July } & 18^{\star} \\
\text { Sept. } & 9^{\star}\end{array}$ & $\begin{array}{l}6.63 \\
6.69 \\
6.61 \\
4.89 \\
4.02 \\
5.38 \\
7.48\end{array}$ & $\begin{array}{lrl}\text { Oct. } & 7, & 1949 \\
\text { Nov. } & 18 & \\
\text { Dec. } & 20 & \\
\text { Jan. } & 20, & 1950 \\
\text { Mar. } & 16 & \\
\text { May } & 9 & \end{array}$ & $\begin{array}{l}7.67 \\
7.65 \\
7.74 \\
7.67 \\
7.72 \\
7.66\end{array}$ & $\begin{array}{lrl}\text { June } & 21, & 1950 \\
\text { July } & 20 & \\
\text { Aug. } & 21 \\
\text { Sept. } & 19 \\
\text { Oct. } & 19 \\
\text { Dec. } & 6\end{array}$ & $\begin{array}{l}7.32 \\
8.04 \\
8.03 \\
8.22 \\
8.36 \\
8.23\end{array}$ \\
\hline
\end{tabular}

4-25-27daa2

\begin{tabular}{ll|l||lr|r||l|l|l}
\hline Dec. & $7,1948^{*}$ & 7.15 & July $18,1949^{*}$ & 7.30 & Aug. 21, 1950 & 7.95 \\
Jan & $7,1949^{*}$ & 7.23 & Mar. 16,1950 & 7.86 & Sept. 19 & 8.03 \\
Feb. & $3^{*}$ & 6.86 & May & 9 & 7.30 & Oct. 19 & 8.22 \\
Apr. & $7^{*}$ & 5.87 & June 21 & 8.25 & Dec. 6 & 7.98 \\
June & $6^{*}$ & 5.78 & July 20 & 8.44 & & & \\
\hline
\end{tabular}


GROUND-WATER GEOLOGY, REPUBLICAN AND FRENCHMAN VALLEYS, NEBR. 657

Water-level measurements in wells, in feet below land-surface datum, with recorder chart readings of lowest daily water levels in 1950-Continued

\begin{tabular}{c|l||l|l||l|l|l}
\hline Date & $\begin{array}{l}\text { Water } \\
\text { level }\end{array}$ & Date & $\begin{array}{l}\text { Water } \\
\text { level }\end{array}$ & Date & $\begin{array}{l}\text { Water } \\
\text { level }\end{array}$ \\
\hline
\end{tabular}

FURNAS COUNTY-Continued

$4-25-30 \mathrm{dd}$

\begin{tabular}{|l|l|l|l|l|l|l|r|}
\hline June & 14,1950 & 8.27 & Aug. 15, 1950 & 8.45 & Oct. 17, 1950 & 8.86 \\
July 19 & 8.40 & Sept. 17 & 8.60 & Dec. 6 & 8.99 \\
\hline
\end{tabular}

4-25-31bb

\begin{tabular}{ll|l||l|l||l|l|l|}
\hline June & 14,1950 & 6.88 & Aug. 15,1950 & 6.82 & Oct. 17, 1950 & 7.63 \\
July 19 & 7.12 & Sept. 17 & 7.35 & Dec. 6 & 7.76 \\
\hline
\end{tabular}

4-25-32ab

\begin{tabular}{ll|l||l|l||l|l|l|}
\hline Jume & 14,1950 & 6.37 & Aug. 15,1950 & 6.49 & Oct. 17, 1950 & 7.07 \\
July 19 & 7.00 & Sept. 17 & 6.86 & Dec. 6 & 6.72 \\
\hline
\end{tabular}

4-25-32bb

\begin{tabular}{|l|l||l|l||lr|r|r}
\hline June & 14,1950 & 8.12 & Aug. 15, 1950 & 8.80 & Oct. 17, 1950 & 9.31 \\
July & 19 & 8.50 & Sept. 17 & 9.08 & Dec. 6 & 9.39 \\
\hline
\end{tabular}

4-25-32cd

\begin{tabular}{ll|r||l|l||lr|r}
\hline Feb. & 2,1948 & 5.35 & June 6,1949 & 4.00 & May 2,1950 & 5.03 \\
Apr. & 9 & 5.05 & Aug. 1 & 5.60 & June 9 & 4.70 \\
June & 7 & 5.79 & Sept. $9 *$ & 5.10 & July 18 & 4.94 \\
Aug. & 2 & 5.12 & Oct. 3 & 5.60 & Aug. 15 & 4.55 \\
Oct. & 1 & 6.58 & Nov. 15 & 5.40 & Sept. 19 & 5.15 \\
Dec. 6 & 5.62 & Dec. 17 & 5.20 & Oct. 18 & 5.37 \\
Feb. 7,1949 & 5.37 & Jan. 19, 1950 & 5.10 & Dec. 5 & 5.17 \\
Apr. & 7 & 3.06 & Mar. 16 & 4.60 & & \\
\hline
\end{tabular}

4-25-33cb

\begin{tabular}{|c|c||l|l||lr|r}
\hline June & 9,1950 & 4.84 & Aug. 17, 1950 & 5.79 & Oct. 18, 1950 & 6.03 \\
July 18 & 6.26 & Sept. 17 & 6.05 & Dec. 5 & 4.61 \\
\hline
\end{tabular}

4-25-33db

\begin{tabular}{|c|c||l|l||l|l|l}
\hline Jume & 9,1950 & 3.53 & Aug. 17, 1950 & 3.56 & Oct. 18, 1950 & 4.19 \\
July 18 & 4.37 & Sept. 17 & 3.92 & Dec. 5 & 5.31 \\
\hline
\end{tabular}

4-25-34aa

\begin{tabular}{|l|l||l|l||l|l|l}
\hline June & 9,1950 & 4.12 & Aug. 17, 1950 & 4.55 & Oct. 18, 1950 & 5.75 \\
July 18 & 5.44 & Sept. 17 & 5.34 & Dec. 5 & 5.73 \\
\hline
\end{tabular}

4-25-34ad

\begin{tabular}{ll|r||lr|r||lr|r}
\hline Feb. & 2,1948 & 17.02 & June 6,1949 & 14.13 & May 12,1950 & 15.50 \\
Apr. & 9 & 16.29 & Aug. 1 & 11.39 & June 9 & 14.96 \\
Jume & 7 & 17.54 & Oct. 3 & 17.05 & July 18 & 16.68 \\
Aug. & 2 & 17.19 & Nov. 15 & 16.78 & Aug. 17 & 15.51 \\
Dec. 6 & 16.86 & Dec. 17 & & 16.62 & Sept. 17 & 16.09 \\
Feb. 7,1949 & 16.54 & Jan. 19, 1950 & 16.53 & Oct. 18 & 16.54 \\
Apr. 7 & 14.65 & Mar. 16 & 16.00 & Dec. 5 & 16.57 \\
\hline
\end{tabular}


Water-level measurements in wells, in feet below land-surface datum, with recorder chart readings of lowest daily water levels in 1950-Continued

\begin{tabular}{l|l||l|l||l|l}
\hline Date & $\begin{array}{l}\text { Water } \\
\text { level }\end{array}$ & Date & $\begin{array}{l}\text { Water } \\
\text { level }\end{array}$ & Date & $\begin{array}{l}\text { Water } \\
\text { level }\end{array}$ \\
\hline
\end{tabular}

FURNAS COUNTY-Continued

4-25-34dc

\begin{tabular}{|c|c||l|l||l|l|l|}
\hline Jume & 9,1950 & 18.71 & Aug. 17, 1950 & 18.58 & Oct. 18, 1950 & 18.67 \\
July 18 & 18.89 & Sept. 17 & 18.46 & Dec. 5 & 18.82 \\
\hline
\end{tabular}

$4-25-36 a b$

\begin{tabular}{|c|c|c|c|c|c|}
\hline $\begin{array}{lrl}\text { Jume } & 9,1950 \\
\text { July } & 22\end{array}$ & $\begin{array}{l}4.32 \\
5.62\end{array}$ & $\begin{array}{l}\text { Aug. } 17,1950 \\
\text { Sept. } 17\end{array}$ & $\begin{array}{l}5.27 \\
5.40\end{array}$ & $\begin{array}{l}\text { Oct, } 18,1950 \\
\text { Dec. } 5\end{array}$ & $\begin{array}{l}5.51 \\
5.18\end{array}$ \\
\hline
\end{tabular}

$4-25-36 c b$

\begin{tabular}{|c|c|c|c|c|c|}
\hline $\begin{array}{lrl}\text { June } & 9,1950 \\
\text { July } & 22 & \end{array}$ & $\begin{array}{l}34.44 \\
34.52\end{array}$ & $\begin{array}{l}\text { Aug. 17, } 1950 \\
\text { Sept. } 17\end{array}$ & $\begin{array}{l}34.49 \\
34.48\end{array}$ & Oct. 18,1950 & $\begin{array}{l}34.65 \\
34.86\end{array}$ \\
\hline
\end{tabular}

\section{HARLAN COUNTY}

$2-18-29 c c$

\begin{tabular}{|c|c|c|c|c|c|}
\hline $\begin{array}{ll}\text { June } & 27,1950 \\
\text { July } & 22\end{array}$ & $\begin{array}{l}17.88 \\
17.98\end{array}$ & $\begin{array}{lll}\text { Aug. } & 18,1950 \\
\text { Sept. } & 18\end{array}$ & $\begin{array}{l}18.01 \\
18.12\end{array}$ & $\begin{array}{ll}\text { Oct. } & 25,1950 \\
\text { Dec. } & 12\end{array}$ & $\begin{array}{l}17.81 \\
17.79\end{array}$ \\
\hline
\end{tabular}

$2-18-30 c b$

\begin{tabular}{l|l||l|l||l|l|}
\hline Oct. 25,1950 & 43.90 & Dec. 12,1950 & 43.89 & & \\
\hline
\end{tabular}

$2-18-33 \mathrm{~cd}$

\begin{tabular}{|c|c|c|c|c|c|c|c|}
\hline $\begin{array}{lr}\text { Sept. } & 27 \\
\text { Nov. } & 26 \\
\text { Jan. } & 1 \\
\text { Mar. } & 12 \\
\text { May } & 11 \\
\text { June } & 21 \\
\text { July } & 22 \\
\text { Aug. } & 24 \\
\text { Sept. } & 26 \\
\text { Oct. } & 29 \\
\text { Dec. } & 3 \\
\text { Jan. } & 6 \\
\text { Jan. } & 25 \\
\text { Apr. } & 4 \\
\text { June } & 13 \\
\text { Aug. } & 11 \\
\text { Sept. } & 20 \\
\text { Dec. } & 11 \\
\text { Apr. } & 11\end{array}$ & $\begin{array}{ll}27, & 1934 \\
26 & \\
1, & 1935 \\
12 & \\
11 & \\
21 & \\
22 & \\
24 & \\
26 & \\
29 & \\
3 & \\
6, & 1936 \\
25 & \\
4 & \\
13 & \\
11 & \\
20 & \\
11 & \\
11, & \\
1937\end{array}$ & $\begin{array}{l}14.42 \\
14.35 \\
14.19 \\
14.05 \\
14.04 \\
12.41 \\
11.28 \\
11.73 \\
11.15 \\
11.47 \\
11.85 \\
12.01 \\
12.13 \\
12.39 \\
11.90 \\
12.68 \\
13.03 \\
13.41 \\
13.06\end{array}$ & 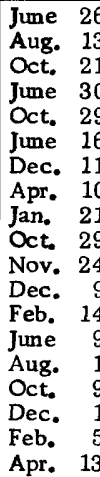 & $\begin{array}{ll}6, & 1937 \\
3 & \\
1 & \\
0, & 1938 \\
9 & \\
6, & 1939 \\
1 & \\
0, & 1940 \\
1, & 1941 \\
9 & \\
4, & 1942 \\
9, & 1944 \\
4, & 1946 \\
9, & 1947 \\
1 & \\
9 & \\
1 & \\
5, & 1948 \\
3 & \end{array}$ & $\begin{array}{r}13.00 \\
13.22 \\
13.58 \\
13.13 \\
13.20 \\
12.97 \\
13.62 \\
13.21 \\
12.89 \\
12.93 \\
11.25 \\
11.17 \\
11.80 \\
8.55 \\
5.68 \\
9.50 \\
10.12 \\
10.39 \\
10.05\end{array}$ & $\begin{array}{lrl}\text { June } & 11, & 1948 \\
\text { Aug. } & 5 & \\
\text { Oct. } & 7 & \\
\text { Dec. } & 10 & \\
\text { Feb. } & 10, & 1949 \\
\text { Apr. } & 7 & \\
\text { June } & 11 & \\
\text { Aug. } & 6 & \\
\text { Oct. } & 8 & \\
\text { Nov. } & 19 & \\
\text { Dec. } & 21 & \\
\text { Feb. } & 8, & 1950 \\
\text { Mar. } & 22 & \\
\text { May } & 4 & \\
\text { June } & 27 & \\
\text { Aug. } & 18 & \\
\text { Sept. } & 18 & \\
\text { Oct. } & 25 & \\
\text { Dec. } & 12 & \end{array}$ & $\begin{array}{r}10.22 \\
9.93 \\
11.22 \\
10.56 \\
11.75 \\
10.80 \\
9.00 \\
9.38 \\
10.80 \\
11.02 \\
11.22 \\
11.27 \\
11.06 \\
11.48 \\
11.10 \\
11.35 \\
11.59 \\
11.61 \\
11.72\end{array}$ \\
\hline
\end{tabular}

$2-19-5 b c$

\begin{tabular}{l|l||l|l||l|l|}
\hline Mar. 22, 1950 & 7.15 & July 22, 1950 & 8.12 & Oct. 25, 1950 & 7.71 \\
May 5 & 7.18 & Aug. 18 & 7.86 & Dec. 12 & 7.39 \\
Jume 27 & 7.49 & Sept. 18 & 7.85 & & \\
\hline
\end{tabular}


GROUND-WATER GEOLOGY, REPUBLICAN AND FRENCHMAN VALLEYS, NEBR, 659

Water level measurements in wells, in feet below land-surface datum, with recorder chart readings of lowest daily water levels in 1950-Continued

\begin{tabular}{c|c||l|l|l|l}
\hline Date & $\begin{array}{l}\text { Water } \\
\text { level }\end{array}$ & Date & $\begin{array}{l}\text { Water } \\
\text { level }\end{array}$ & Date & $\begin{array}{l}\text { Water } \\
\text { level }\end{array}$ \\
\hline
\end{tabular}

HARLAN COUNTY-Continued

$2-19-5 \mathrm{cb}$

\begin{tabular}{|c|c|c|c|c|c|c|c|c|c|}
\hline $\begin{array}{l}\text { Feb. } \\
\text { Apr. } \\
\text { June } \\
\text { Oct. } \\
\text { Dec. } \\
\text { Feb. } \\
\text { Apr. }\end{array}$ & $\begin{aligned} 5, & 1948 \\
13 & \\
11 & \\
7 & \\
10 & \\
10, & 1949 \\
7 & \end{aligned}$ & $\begin{array}{l}20.90 \\
20.70 \\
21.62 \\
22.65 \\
21.42 \\
20.96 \\
20.32\end{array}$ & $\begin{array}{l}\text { Jume } \\
\text { Oct. } \\
\text { Nov. } \\
\text { Dec. } \\
\text { Feb. } \\
\text { Mar. } \\
\text { May }\end{array}$ & $\begin{array}{r}11 \\
8 \\
19 \\
21 \\
8 \\
22 \\
5\end{array}$ & $\begin{array}{l}1949 \\
1950\end{array}$ & $\begin{array}{l}19.99 \\
21.40 \\
21.04 \\
20.89 \\
20.80 \\
19.98 \\
20.56\end{array}$ & $\begin{array}{l}\text { June } \\
\text { July } \\
\text { Aug. } \\
\text { Sept. } \\
\text { Oct. } \\
\text { Dec. }\end{array}$ & $\begin{array}{ll}27, & 1950 \\
22 & \\
18 & \\
18 & \\
25 & \\
12 & \end{array}$ & $\begin{array}{l}20.85 \\
22.06 \\
21.40 \\
21.32 \\
21.22 \\
20.84\end{array}$ \\
\hline
\end{tabular}

$2-19-6$ ba

\begin{tabular}{l|l||l|l||ll|l}
\hline Jume 27,1950 & 4.32 & Aug. 18, 1950 & 5.09 & Oct. 25, 1950 & 5.20 \\
July 22 & 5.21 & Sept. 18 & 5.93 & Dec. 12 & 4.34 \\
\hline
\end{tabular}

$2-19-7 \mathrm{da}$

\begin{tabular}{|l|l||l|l||l|l|}
\hline June 27,1950 & 5.16 & Sept. 18, 1950 & 5.71 & Dec. 12, 1950 & 5.61 \\
July 22 & 6.02 & Oct. 25 & 5.91 & & \\
\hline
\end{tabular}

$2-19-8 b c$

\begin{tabular}{l|l||l|l||l|l|l}
\hline Feb. 8,1950 & 4.90 & June 27,1950 & 5.56 & Sept. 18, 1950 & 5.88 \\
Mar. 22 & 4.13 & July 22 & 6.18 & Oct. 25 & 5.95 \\
May 4 & 4.57 & Aug. 18 & 5.33 & Dec. 12 & 5.57 \\
\hline
\end{tabular}

2-19-8bd

\begin{tabular}{l|l||l|l||l|l|l}
\hline June 27,1950 & 13.61 & Aug. 18, 1950 & 13.82 & Oct. 25, 1950 & 14.53 \\
July 22 & 14.27 & Sept. 18 & 14.30 & Dec. 12 & 14.02 \\
\hline
\end{tabular}

2-19-16cc

\begin{tabular}{|l|l||l|l||l|l|l}
\hline June & 27,1950 & 20.93 & Aug. 18, 1950 & 21.31 & Oct. 25, 1950 & 21.54 \\
July & 22 & 21.08 & Sept. 18 & 21.39 & Dec. 12 & 21.70 \\
\hline
\end{tabular}

2-19-17cb

\begin{tabular}{l|l||l|l||l|l|l}
\hline Feb. 10, 1950 & 5.15 & June 27, 1950 & 5.17 & Sept. 18, 1950 & 5.82 \\
Mar. 22 & 4.26 & July 22 & 5.84 & Oct. 25 & 6.06 \\
May 4 & 4.57 & Aug. 18 & 5.35 & Dec. 12 & 5.56 \\
\hline
\end{tabular}

2-19-17da

\begin{tabular}{l|r||l|l||l|l}
\hline Feb. 2,1948 & 20.77 & June 11, 1949 & 19.37 & May 4, 1950 & 21.15 \\
Apr. 13 & 20.36 & Aug. 6 & 20.68 & June 27 & 21.32 \\
Jume 11 & 21.32 & Oct. 8 & 21.72 & July 22 & 21.93 \\
Aug. 5 & 20.60 & Nov. 19 & 21.63 & Aug. 18 & 21.52 \\
Oct. 7 & 22.16 & Dec. 21 & 21.49 & Sept. 18 & 21.88 \\
Dec. 10 & 22.22 & Feb. 8, 1950 & 21.43 & Oct. 25 & 22.20 \\
Feb. 10, 1949 & 21.68 & Mar. 22 & 20.69 & Dec. 12 & 22.01 \\
Apr. 7 & 20.12 & & & & \\
\hline
\end{tabular}


Water-level measurements in wells, in feet below land-surface datum, with recorder chart readings of lowest daily water levels in 1950-Continued

\begin{tabular}{c|l||l|l||l|l|l|}
\hline Date & $\begin{array}{l}\text { Water } \\
\text { level }\end{array}$ & Date & $\begin{array}{l}\text { Water } \\
\text { level }\end{array}$ & $\begin{array}{l}\text { Water } \\
\text { level }\end{array}$ \\
\hline
\end{tabular}

HARLAN COUNTY-Continued

\begin{tabular}{l|l||l|l||l|l|l|}
\hline \multicolumn{1}{|c|}{$2-19-17 \mathrm{dd}$} \\
June 27, 1950 & 6.19 & Aug. 18, 1950 & 5.33 & Oct. 25, 1950 & 6.58 \\
July 22 & 6.45 & Sept. 18 & 5.68 & Dec. 12 & 6.20 \\
\hline
\end{tabular}

2-19-22cb

\begin{tabular}{l|l|l|l|l||ll|l|}
\hline May & 4,1950 & 24.61 & Aug. 18, 1950 & 25.70 & Oct. 25, 1950 & 25.98 \\
June 27 & 25.08 & Sept. 18 & 26.19 & Dec. 12 & \\
July 22 & 26.42 & & & & & \\
\hline
\end{tabular}

2-19-28aa

\begin{tabular}{l|r||l|l||l|r}
\hline Feb. 10, 1950 & 10.00 & June 27, 1950 & 8.71 & Sept. 18, 1950 & 9.32 \\
Mar. 22 & 9.25 & July 22 & 9.20 & Oct. 25 & 9.07 \\
May 4 & 9.28 & Aug. 18 & 9.05 & Dec. 12 & 10.12 \\
\hline
\end{tabular}

2-19-28da

\begin{tabular}{l|l||l|l||l|l|}
\hline Feb. 10, 1950 & 7.76 & June 27, 1950 & 7.95 & Sept. 18, 1950 & 8.24 \\
Mar. 22 & 7.57 & July 22 & 8.12 & Oct. 25 & 8.65 \\
May 4 & 7.70 & Aug. 18 & 7.30 & Dec. 12 & 8.65 \\
\hline
\end{tabular}

$2-19-28 d d$

\begin{tabular}{lr|r||l|l||lr|r}
\hline Feb. 5, 1948 & 9.04 & June 11, 1949 & 6.59 & May 4, 1950 & 8.71 \\
Apr. 13 & 8.74 & Aug. 6 & 8.92 & June 27 & 9.05 \\
June 11 & 9.34 & Oct. 8 & 9.50 & July 22 & 9.06 \\
Aug. & 5 & 8.12 & Nov. 19 & 9.15 & Aug. 18 & 8.37 \\
Oct. 7 & 9.80 & Dec. 21 & 9.03 & Sept. 18 & 9.15 \\
Dec. 10 & 9.25 & Feb. 10, 1950 & 8.60 & Oct. 25 & 9.73 \\
Feb. 10, 1949 & 8.38 & Mar. 22 & 8.60 & Dec. 12 & 9.71 \\
Apr. 7 & 7.66 & & & & & \\
\hline
\end{tabular}

2-19-34bc

\begin{tabular}{lr|r||lr|r||l|l|}
\hline Feb. 5, 1948 & 21.15 & Apr. 7,1949 & 20.20 & May 4, 1950 & 21.04 \\
Apr. 13 & 21.03 & June 11 & 19.53 & June 27 & 21.49 \\
June 11 & 21.55 & Oct. 8 & 8 & 21.80 & July 22 & 21.30 \\
Aug. & 5 & 20.95 & Nov. 19 & 21.34 & Aug. 18 & 20.97 \\
Oct. & 7 & 22.10 & Dec. 21 & 21.20 & Sept. 18 & 21.69 \\
Dec. 10 & 21.38 & Feb. 10, 1950 & 20.54 & Oct. 25 & 22.22 \\
Feb. 10, 1949 & 20.53 & Mar. 22 & 20.77 & Dec. 12 & 22.07 \\
\hline
\end{tabular}

3-20-7aa

\begin{tabular}{ll|l||l|l||l|l|}
\hline Jume 27,1950 & 26.91 & Aug. 17, 1950 & 27.96 & Oct. 24, 1950 & 27.31 \\
July 21 & 27.23 & Sept. 18 & 27.23 & Dec. 12 & 27.15 \\
\hline
\end{tabular}

3-20-7ab

\begin{tabular}{l|r||lr|l||ll|l}
\hline Feb. 5,1948 & 29.82 & June 11,1949 & 29.60 & May 5, 1950 & 29.16 \\
Apr. 13 & 29.82 & Aug. & 6 & 29.95 & June 27 & 29.36 \\
Oct. 7 & 30.22 & Oct. 8 & 29.80 & July 21 & 30.48 \\
Dec. 10 & 30.05 & Nov. 19 & 29.55 & Sept. 18 & 29.72 \\
Feb. 10,1949 & 29.70 & Dec. 21 & 29.45 & Oct. 24 & 29.83 \\
Apr. 7 & 29.30 & Feb. 8,1950 & 29.32 & Dec. 12 & 29.59 \\
\hline
\end{tabular}


GROUND-WATER GEOLOGY, REPUBLICAN AND FRENCHMAN VALLEYS, NEBR. 661

Water-level measurements in wells, in teet below land-surface datum, with recorder chart readings of lowest daily water levels in 1950 - Continued

\begin{tabular}{c|l||l|l||l|l}
\hline Date & $\begin{array}{l}\text { Water } \\
\text { level }\end{array}$ & Date & $\begin{array}{l}\text { Water } \\
\text { level }\end{array}$ & Date & $\begin{array}{l}\text { Water } \\
\text { level }\end{array}$ \\
\hline
\end{tabular}

HARLAN COUNTY-Continued

$$
3-20-7 \mathrm{ad}
$$

\begin{tabular}{ll|r||l|r||l|r|}
\hline Jume & 27,1950 & 13.26 & Aug. 17, 1950 & 8.94 & Oct. 24, 1950 & 12.10 \\
July 21 & 7.25 & Sept. 18 & 10.54 & Dec. 12 & 12.94 \\
\hline
\end{tabular}

3-20-8dd

\begin{tabular}{|l|l||l|l||l|r|r}
\hline June 27, 1950 & 4.68 & Aug. 17, 1950 & 4.58 & Oct. 24, 1950 & 5.27 \\
July 21 & 4.21 & Sept. 18 & 4.97 & Dec. 12 & 5.04 \\
\hline
\end{tabular}

$3-20-16 b b$

\begin{tabular}{l|r||l|l||lr|r}
\hline Feb. 5, 1948 & 7.65 & June 11, 1949 & 3.89 & May 5, 1950 & 6.83 \\
Apr. 13 & 6.93 & Aug. 6 & 7.40 & June 27 & 6.55 \\
Jume 11 & 7.85 & Oct. 8 & 8.10 & July 21 & 5.93 \\
Aug. 5 & 7.08 & Nov. 19 & 7.57 & Aug. 17 & 6.98 \\
Oct. 7 & 8.74 & Dec. 21 & 7.40 & Sept. 18 & 7.52 \\
Dec. 10 & 7.95 & Feb. 8, 1950 & 7.17 & Oct. 24 & 7.61 \\
Feb. 10, 1949 & 7.50 & Mar. 20 & 6.71 & Dec. 12 & 7.29 \\
Apr. 7 & 5.82 & & & & \\
\hline
\end{tabular}

$3-20-16 b d$

\begin{tabular}{|l|l||l|l||l|l|}
\hline June 27,1950 & 3.87 & Aug. 17, 1950 & 4.95 & Oct. 24, 1950 & 5.73 \\
July 21 & 4.34 & Sept. 18 & 5.53 & Dec. 12 & 5.41 \\
\hline
\end{tabular}

$3-20-16 c d$

\begin{tabular}{l|l||l|l||l|l|}
\hline Feb. 8,1950 & 5.57 & June 27, 1950 & 5.07 & Sept. 18, 1950 & 6.30 \\
Mar. 20 & 5.24 & July 21 & 5.31 & Oct. 25 & 6.25 \\
May 5 & 5.27 & Aug. 17 & 5.96 & Dec. 12 & 5.88 \\
\hline
\end{tabular}

$3-20-16 \mathrm{dd}$

\begin{tabular}{l|r||l|r||l|r|}
\hline June 27, 1950 & 8.69 & Aug. 17, 1950 & 9.88 & Oct. 25, 1950 & 10.42 \\
July 21 & 9.18 & Sept. 18 & 10.37 & Dec. 12 & 10.16 \\
\hline
\end{tabular}

3-20-17aa

\begin{tabular}{l|l||l|l||l|l}
\hline Feb. 8,1950 & 5.20 & June 27, 1950 & 5.02 & Sept. 18, 1950 & 5.53 \\
Mar, 20 & 4.71 & July 21 & 4.08 & Oct. 24 & 5.62 \\
May 5 & 4.93 & Aug. 17 & 5.11 & Dec. 12 & 5.29 \\
\hline
\end{tabular}

$3-20-18 \mathrm{cb}$

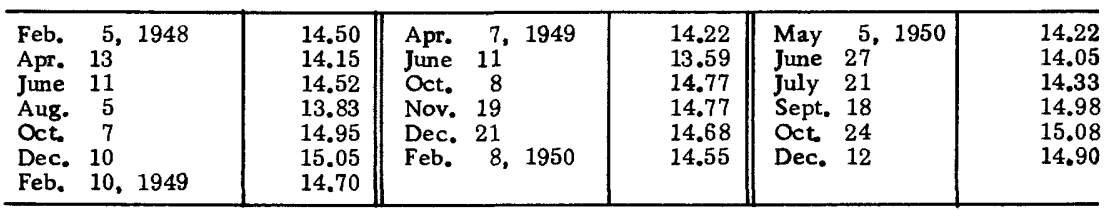


Water-level measurements in wells, in feet below land-surface datum, with recorder chart readings of lowest daily water levels in 1950-Continued

\begin{tabular}{l|l||l|l||l|l|l|l|}
\hline Date & $\begin{array}{l}\text { Water } \\
\text { level }\end{array}$ & Date & $\begin{array}{l}\text { Water } \\
\text { level }\end{array}$ & $\begin{array}{l}\text { Water } \\
\text { level }\end{array}$ \\
\hline
\end{tabular}

HARLAN COUNTY-Continued

$3-20-21$ ac

\begin{tabular}{|l|l||l|l||l|l|}
\hline June 27, 1950 & 8.71 & Aug. 17, 1950 & 8.85 & Oct. 24, 1950 & 8.69 \\
July 21 & 8.99 & Sept. 18 & 8.93 & Dec. 12 & 8.40 \\
\hline
\end{tabular}

$3-20-22 b a$

\begin{tabular}{ll|l|l|l||l|l|}
\hline June & 27,1950 & 12.78 & Aug. 17, 1950 & 13.55 & Oct. 25, 1950 & 13.82 \\
July 21 & 13.28 & Sept. 18 & 13.78 & Dec. 12 & 13.69 \\
\hline
\end{tabular}

3-20-22dd

\begin{tabular}{|c|c|c|c|c|c|}
\hline $\begin{array}{lr}\text { Feb. } & 5,1948 \\
\text { Apr. } & 13 \\
\text { June } & 11 \\
\text { Aug. } & 5 \\
\text { Oct. } & 7 \\
\text { Dec. } & 10\end{array}$ & $\begin{array}{l}25.29 \\
25.25 \\
25.90 \\
25.38 \\
25.83 \\
25.30\end{array}$ & $\begin{array}{lrl}\text { Feb. } & 10, & 1949 \\
\text { Apr. } & 7 & \\
\text { June } & 11 & \\
\text { Aug. } & 6 \\
\text { Oct. } & 8 & \\
\text { Nov. } & 19 & \end{array}$ & $\begin{array}{l}24.87 \\
24.52 \\
24.13 \\
25.06 \\
25.50 \\
24.95\end{array}$ & $\begin{array}{lrr}\text { Dec. } & 21, & 1949 \\
\text { Mar. } & 22, & 1950 \\
\text { May } & 5 & \\
\text { June } & 27 & \\
\text { July } & 21 & \end{array}$ & $\begin{array}{l}24.81 \\
24.66 \\
24.65 \\
25.33 \\
25.74\end{array}$ \\
\hline
\end{tabular}

$3-20-23 c d$

\begin{tabular}{|l|l||l|l||l|r|}
\hline June 27,1950 & 18.02 & Aug. 18, 1950 & 14.78 & Oct. 24, 1950 & 17.09 \\
July 21 & 18.39 & Sept. 18 & 15.41 & Dec. 12 & 18.21 \\
\hline
\end{tabular}

3-20-25cc

\begin{tabular}{l|r||l|l||l|l}
\hline Feb. 5,1948 & 13.86 & June 11, 1949 & 11.56 & May 5, 1950 & 14.37 \\
Apr. 13 & 13.11 & Aug. 5 & 13.23 & June 27 & 14.67 \\
June 11 & 14.42 & Oct. 8 & 15.02 & July 21 & 15.33 \\
Aug. 5 & 13.42 & Nov. 19 & 15.07 & Aug. 18 & 15.02 \\
Oct. 7 & 15.50 & Dec. 21 & 14.97 & Sept. 18 & 15.44 \\
Dec. 10 & 15.43 & Feb. 8, 1950 & 14.80 & Oct. 25 & 15.85 \\
Feb. 10, 1949 & 14.32 & Mar. 22 & 14.35 & Dec. 12 & 15.44 \\
Apr. 7 & 13.20 & & & & \\
\hline
\end{tabular}

\begin{tabular}{l|l||l|l||l|l}
\hline \multicolumn{8}{c}{$3-20-35 \mathrm{aab}$} \\
\hline Feb. 8,1950 & 6.20 & June 27,1950 & 5.90 & Sept. 18, 1950 & 6.61 \\
Mar. 22 & 5.80 & July 21 & 6.47 & Oct. 25 & 6.99 \\
May 5 & 6.08 & Aug. 18 & 5.99 & Dec. 12 & 6.76 \\
\hline
\end{tabular}

3-20-35aad

\begin{tabular}{l|l||l|l||l|l|}
\hline Feb. 8, 1950 & 5.30 & June 27, 1950 & 4.37 & Sept. 18, 1950 & 5.53 \\
Mar. 22 & 4.45 & July 21 & 4.66 & Oct. 25 & 5.95 \\
May 5 & 4.58 & Aug. 18 & 4.13 & Dec. 12 & 5.63 \\
\hline
\end{tabular}

3-20-36da

\begin{tabular}{|l|l||l|l||l|l|l}
\hline Jume 27, 1950 & 8.31 & Aug. 18, 1950 & 9.74 & Oct. 25, 1950 & 9.33 \\
July 22 & 8.77 & Sept. 18 & 8.95 & Dec. 12 & 9.22 \\
\hline
\end{tabular}

$3-20-36 \mathrm{db}$

\begin{tabular}{|l|l||l|l||l|l|}
\hline June 27,1950 & 4.92 & Aug. 18, 1950 & 5.75 & Oct. 25, 1950 & 6.54 \\
July 22 & 5.68 & Sept. 18 & 6.33 & Dec. 12 & 6.10 \\
\hline
\end{tabular}


GROUND-WATER GEOLOGY, REPUBLICAN AND FRENCHMAN VALLEYS, NEBR. 663

Water-level measurements in wells, in feet below land-surface datum, with recorder chart readings of lowest daily water levels in 1950 - Continued

\begin{tabular}{c|c||l|l||l|l|l}
\hline Date & $\begin{array}{l}\text { Water } \\
\text { level }\end{array}$ & Date & $\begin{array}{l}\text { Water } \\
\text { level }\end{array}$ & $\begin{array}{l}\text { Water } \\
\text { level }\end{array}$ \\
\hline
\end{tabular}

\section{HAYES COUNTY}

$5-33-30 \mathrm{cb}$

\begin{tabular}{lr|r||lr|r||l|l|l}
\hline Feb. 4,1948 & 19.26 & June 9,1949 & 17.86 & Mar. 6,1950 & 18.91 \\
Apr. 12 & 19.34 & July $19^{*}$ & 19.32 & Apr. 14 & 18.98 \\
June & 9 & 19.57 & Oct. 6 & 19.40 & July 11 & 19.38 \\
Aug. 4 & 19.71 & Nov. 17 & 19.14 & Sept. 20 & 19.23 \\
Oct. 6 & 19.78 & Dec. 20 & 19.13 & Oct. 16 & 19.28 \\
Dec. 9 & 19.23 & Jan. 19, 1950 & 18.98 & Dec. 6 & 19.13 \\
Apr. 6, 1949 & 18.83 & & & & & \\
\hline
\end{tabular}

5-33-31dc

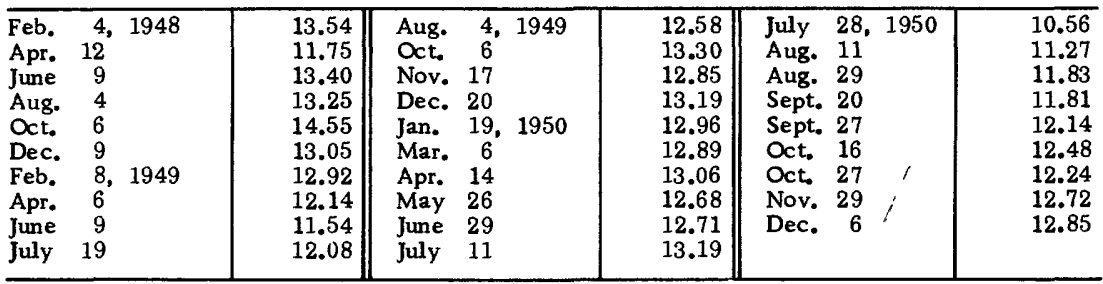

$5-34-28 b c$

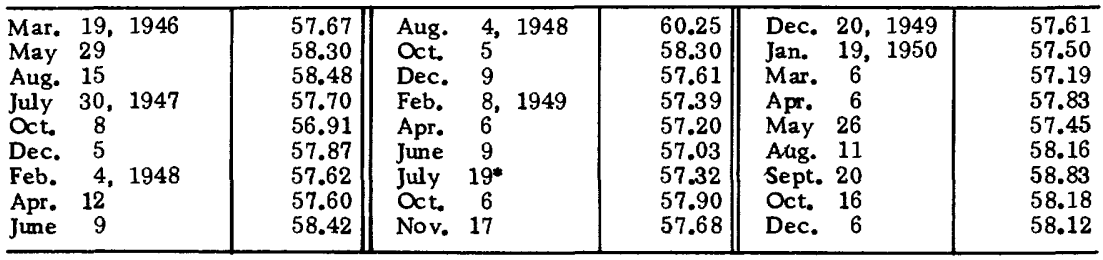

$5-34-30 b a$

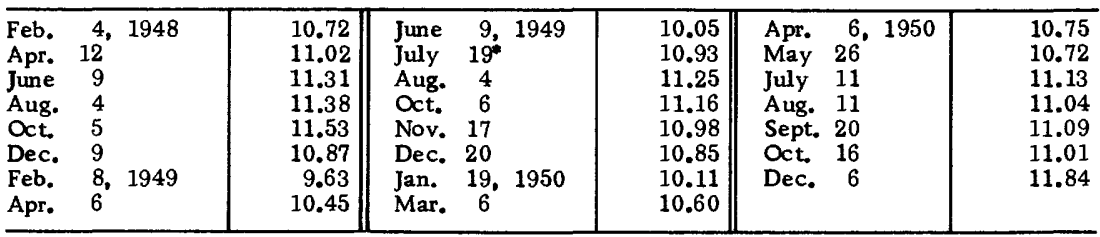

$5-34-34 a a$

\begin{tabular}{|c|c|c|c|c|c|c|}
\hline July & 11,1950 & 20.94 & Sept. 20,1950 & 20.88 & & \\
\hline \multicolumn{7}{|c|}{$5-34-35 a c$} \\
\hline $\begin{array}{l}\text { June } \\
\text { Oct. } \\
\text { Dec. } \\
\text { Feb. } \\
\text { Apr. } \\
\text { June }\end{array}$ & $\begin{array}{ll}9, & 1948 \\
6 & \\
9 & \\
8, & 1949 \\
6 & \\
9 & \end{array}$ & $\begin{array}{l}30.00 \\
30.30 \\
29.29 \\
29.34 \\
28.57 \\
28.02\end{array}$ & $\begin{array}{lrl}\text { Aug. } & 4,1949 \\
\text { Oct. } & 6 & \\
\text { Dec. } & 20 & \\
\text { Jan. } & 19, & 1950 \\
\text { Mar. } & 6 & \\
\text { Apr. } & 14 & \end{array}$ & $\begin{array}{l}30.94 \\
29.90 \\
29.79 \\
29.45 \\
29.54 \\
29.81\end{array}$ & $\begin{array}{lll}\text { May } & 26, & 1950 \\
\text { July } & 11 & \\
\text { Aug. } & 11 \\
\text { Sept. } & 20 \\
\text { Oct. } & 16 \\
\text { Dec. } 6 & \end{array}$ & $\begin{array}{l}29.80 \\
30.34 \\
30.17 \\
30.22 \\
30.23 \\
30.73\end{array}$ \\
\hline
\end{tabular}


Water-level measurements in wells, in feet below land-surface datum, with recorder chart readings of lowest daily water levels in 1950-Continued

\begin{tabular}{c|l||l|l||l|l}
\hline Date & $\begin{array}{l}\text { Water } \\
\text { level }\end{array}$ & Date & $\begin{array}{l}\text { Water } \\
\text { level }\end{array}$ & Date & $\begin{array}{l}\text { Water } \\
\text { level }\end{array}$ \\
\hline
\end{tabular}

HAYES COUNTY-Continued

$5-35-7 c c$

\begin{tabular}{ll|l||l|l||l|l|l}
\hline July 11, 1950 & $\begin{array}{l}7.99 \\
\text { Aug. 11 }\end{array}$ & $\begin{array}{l}\text { Sept. 20, 1950 } \\
\text { Oct. 16 }\end{array}$ & $\begin{array}{l}7.77 \\
7.77\end{array}$ & Dec. 7, 1950 & 8.52 \\
\hline
\end{tabular}

5-35-16dd

\begin{tabular}{|c|c|c|c|c|c|c|c|c|}
\hline $\begin{array}{l}\text { Feb. } \\
\text { Apr. } 1 \\
\text { June } 1 \\
\text { Aug. } \\
\text { Oct. } \\
\text { Dec. } 1 \\
\text { Feb. } \\
\text { Apr. }\end{array}$ & $\begin{aligned} 4, & 1948 \\
12 & \\
11 & \\
4 & \\
6 & \\
10 & \\
8, & 1949 \\
6 & \end{aligned}$ & $\begin{array}{l}8.41 \\
8.70 \\
9.15 \\
9.32 \\
9.33 \\
8.58 \\
6.83 \\
7.96\end{array}$ & $\begin{array}{l}\text { June } \\
\text { Aug. } \\
\text { Oct. } \\
\text { Nov. } 1 \\
\text { Dec. } \\
\text { Jan. } \\
\text { Mar. }\end{array}$ & $\begin{aligned} 9, & 1949 \\
4 & \\
6 & \\
17 & \\
20 & \\
19, & 1950 \\
6 & \end{aligned}$ & $\begin{array}{l}7.70 \\
9.20 \\
8.90 \\
8.69 \\
8.62 \\
7.68 \\
8.66\end{array}$ & $\begin{array}{ll}\text { Apr. } & \\
\text { May } & 2 \\
\text { July } & 1 \\
\text { Aug. } & 1 \\
\text { Sept. } & 2 \\
\text { Oct. } & 1 \\
\text { Dec. } & \end{array}$ & $\begin{aligned} 6, & 1950 \\
26 & \\
11 & \\
11 & \\
20 & \\
16 & \\
7 & \end{aligned}$ & $\begin{array}{l}8.50 \\
8.59 \\
9.21 \\
8.97 \\
8.97 \\
8.87 \\
9.74\end{array}$ \\
\hline
\end{tabular}

5-35-17ac

\begin{tabular}{l|l|l|l|l||ll|l|}
\hline July 11, 1950 & $\begin{array}{l}17.85 \\
\text { Aug. } 11\end{array}$ & $\begin{array}{l}\text { Sept. 20, 1950 } \\
\text { Oct. 16 }\end{array}$ & $\begin{array}{l}17.67 \\
17.59\end{array}$ & Dec. 7, 1950 & 18.43 \\
\hline
\end{tabular}

$5-35-23 a c$

\begin{tabular}{|l|l||l|l||l|l|l|}
\hline July 11, 1950 & $\begin{array}{l}17.81 \\
\text { Aug. 11 }\end{array}$ & $\begin{array}{l}\text { Sept. 20, 1950 } \\
\text { Oct. 16 }\end{array}$ & $\begin{array}{l}17.74 \\
17.66\end{array}$ & Dec. 7, 1950 & 19.49 \\
\hline
\end{tabular}

\section{HITCHCOCK COUNTY}

$2-32-6 b c$

\begin{tabular}{|l|l||l|l||lc|r}
\hline June & 19,1950 & 5.90 & Aug. 12, 1950 & 4.59 & Oct. 20, 1950 & 5.88 \\
July 14 & 6.23 & Sept. 22 & 5.77 & Dec. 7 & 5.61 \\
\hline
\end{tabular}

$$
\text { 2-32-6da }
$$

\begin{tabular}{|l|l||l|l||lr|r|}
\hline June 19,1950 & 24.55 & Aug. 12,1950 & 24.16 & Oct. 20, 1950 & 24.17 \\
July 14 & 24.54 & Sept. 22 & 24.11 & Dec. 7 & 24.26 \\
\hline
\end{tabular}

$$
2-32-6 d b
$$

\begin{tabular}{|l|l|l|l|l||l|l|l|}
\hline June & 19,1950 & 25.43 & Sept. 22, 1950 & 25.20 & Dec. 7, 1950 & 25.38 \\
July 14 & 25.49 & Oct. 20 & 25.28 & & & \\
\hline
\end{tabular}

$2-33-1 \mathrm{cc}$

\begin{tabular}{ll|l||l|l||lc|r|r}
\hline June 19,1950 & 14.80 & Aug. 12, 1950 & 14.61 & Oct. 20, 1950 & 14.89 \\
July 14 & 14.95 & Sept. 22 & 14.84 & Dec. 7 & 14.81 \\
\hline
\end{tabular}

\begin{tabular}{|c|c|c|c|c|c|c|c|}
\hline $\begin{array}{l}\text { Feb. } \\
\text { Apr. } 1 \\
\text { Oct. } \\
\text { Dec. } \\
\text { Feb. } \\
\text { Apr. }\end{array}$ & $\begin{array}{cc}4, & 1948 \\
12 & \\
6 & \\
9 & \\
8, & 1949 \\
4 & \end{array}$ & $\begin{array}{r}10.53 \\
10.16 \\
12.05 \\
10.90 \\
10.04 \\
9.51\end{array}$ & $\begin{array}{lrr}\text { June } & 8, & 1949 \\
\text { July } & 5 & \\
\text { Sept. } & 12 \\
\text { Oct. } & 6 \\
\text { Nov. } & 17 \\
\text { Dec. } & 19\end{array}$ & $\begin{array}{r}9.51 \\
10.56 \\
10.78 \\
10.52 \\
10.40 \\
10.35\end{array}$ & $\begin{array}{l}\text { Jan. } \\
\text { Feb. } \\
\text { Apr. } \\
\text { June } \\
\text { July } \\
\text { Aug. }\end{array}$ & $\begin{array}{ll}17, & 1950 \\
23 & \\
26 & \\
2 & \\
13 & \\
12 & \end{array}$ & $\begin{array}{r}10.07 \\
9.93 \\
10.04 \\
10.30 \\
11.18 \\
10.44\end{array}$ \\
\hline
\end{tabular}

2-33-2aa 
GROUND-WATER GEOLOGY, REPUBLICAN AND FRENCHMAN VALLEYS, NEBR. 665

Water-level measurements in wells, in foet below land-surface datum, with recorder chart readings of lowest daily water levels in 1950 - Continued

\begin{tabular}{c|c||c|c||c|c}
\hline Date & $\begin{array}{l}\text { Water } \\
\text { level }\end{array}$ & Date & $\begin{array}{l}\text { Water } \\
\text { level }\end{array}$ & Date & $\begin{array}{l}\text { Water } \\
\text { level }\end{array}$ \\
\hline
\end{tabular}

HITCHCOCK COUNTY-Continued

$2-33-3 b d$

\begin{tabular}{|c|c|c|c|c|c|c|}
\hline $\begin{array}{ll}\text { Feb. } & 2,1950 \\
\text { Mar. } & 10 \\
\text { Apr. } & 26\end{array}$ & $\begin{array}{l}4.98 \\
4.83 \\
4.91\end{array}$ & $\begin{array}{l}\text { June } \\
\text { July } 1 \\
\text { Aug. }\end{array}$ & $\begin{array}{r}5,1950 \\
13 \\
9\end{array}$ & $\begin{array}{l}5.07 \\
6.10 \\
5.09\end{array}$ & $\begin{array}{ll}\text { Oct, } & 17, \\
\text { Dec. } & 8\end{array}$ & $\begin{array}{l}6.00 \\
5.29\end{array}$ \\
\hline
\end{tabular}

2-33-3dd

\begin{tabular}{|c|c|c|c|c|c|c|}
\hline $\begin{array}{l}\text { Aug. } \\
\text { Oct. } \\
\text { Nov. } 1 \\
\text { Dec. } 1 \\
\text { Feb. }\end{array}$ & $\begin{array}{rr}3, & 1949 \\
6 & \\
15 & \\
17 & \\
2, & 1950\end{array}$ & $\begin{array}{l}9.54 \\
9.55 \\
9.28 \\
9.22 \\
8.64\end{array}$ & $\begin{array}{lrl}\text { Mar. } & 10,1950 \\
\text { Apr. } & 26 \\
\text { June } & 5 \\
\text { July } & 13\end{array}$ & $\begin{array}{l}8.75 \\
8.83 \\
8.98 \\
9.46\end{array}$ & $\begin{array}{ll}\text { Aug. } & 10,1950 \\
\text { Sept. } & 12 \\
\text { Oct. } & 17 \\
\text { Dec. } & 8\end{array}$ & $\begin{array}{l}8.58 \\
9.28 \\
9.26 \\
9.06\end{array}$ \\
\hline
\end{tabular}

$2-33-4 a d$

\begin{tabular}{l|r|r||l|l||l|l|l}
\hline Oct. 5, 1949 & 13.28 & Mar. 10, 1950 & 11.91 & Aug. 9, 1950 & 13.06 \\
Nov. 17 & 12.87 & Apr. 26 & 11.68 & Sept. 12 & 13.15 \\
Dec. 17 & 12.54 & June & 5 & 11.67 & Oct. 17 & 12.94 \\
Feb. 2, 1950 & 12.37 & July 13 & 12.74 & Dec. 8 & 12.65 \\
\hline
\end{tabular}

$2-33-4 \mathrm{da}$

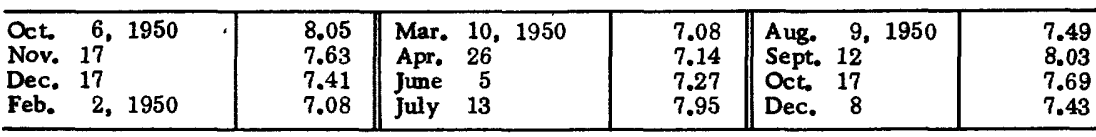

$2-33-6 c b$

\begin{tabular}{lr|r||lr|r||lr|r}
\hline Feb. & 4,1948 & 9.66 & June & 6,1949 & 8.94 & Mar. 10, 1950 & 8.97 \\
Apr. & 12 & 9.73 & July & 5 & 9.32 & Apr. 26 & 9.02 \\
June & 9 & 10.24 & Aug. & 3 & 10.12 & June 5 & 9.18 \\
Aug. & 4 & 10.82 & Sept. & 7 & 10.14 & July 13 & 9.66 \\
Oct. & 6 & 11.32 & Oct. 4 & 10.35 & Aug. 9 & 9.44 \\
Dec. 9 & 9.96 & Nov. 17 & 9.97 & Sept. 12 & 9.98 \\
Feb. & 8,1949 & 8.65 & Dec. 19 & 9.65 & Oct. 17 & 9.90 \\
Apr. 4 & 7.69 & Feb. & 2,1950 & 8.88 & Dec. 8 & 8.74 \\
\hline
\end{tabular}

2-33-8aaa 1

\begin{tabular}{l|r||l|l||l|l|}
\hline Aug. 3, 1949 & 2.56 & Mar. 10, 1950 & 1.59 & Aug. 10, 1950 & 1.82 \\
Nov. 15 & 2.97 & Apr. 26 & 3.62 & Sept. 12 & 2.85 \\
Dec. 17 & 2.07 & June 5 & 5.04 & Oct. 17 & 2.25 \\
Feb. 2, 1950 & .32 & July 13 & 3.34 & Dec. 8 & 1.90 \\
\hline
\end{tabular}

2-33-8aaa2

\begin{tabular}{l|r||l|l||l|l|}
\hline Aug. $3,1949^{\circ}$ & 4.90 & Mar. 10, 1950 & 4.19 & Aug. 10, 1950 & 4.46 \\
Nov. 15 & 5.75 & Apr. 26 & 6.92 & Sept. 12 & 5.23 \\
Dec. 17 & 4.77 & June 5 & 8.75 & Oct. 17 & 4.86 \\
Feb. 2, 1950 & 3.05 & July 13 & 6.31 & Dec. 8 & 4.51 \\
\hline
\end{tabular}

2-33-8aad

\begin{tabular}{l|l|l|l|l||l|l|l}
\hline Aug. & $3,1949^{\circ}$ & 7.59 & Nov. 15,1949 & 8.95 & Feb. 2, 1950 & 6.24 \\
Sept. & $2^{*}$ & 8.76 & Dec. 18 & & 7.90 & Mar. 10 & 7.12
\end{tabular}


Water-level measurements in wells, in feet below land-surface datum, with recorder chart readings of lowest daily $n$ ater levels in 1950-Continued

\begin{tabular}{c|l||l|l|l|l|l|l|l}
\hline Date & $\begin{array}{l}\text { Water } \\
\text { level }\end{array}$ & Date & $\begin{array}{l}\text { Water } \\
\text { level }\end{array}$ & Date \\
\hline
\end{tabular}

\section{HITCHCOCK COUNTY-Continued}

2-33-8aad-Continued

\begin{tabular}{|c|c|c|c|c|c|c|}
\hline $\begin{array}{l}\text { Apr. } \\
\text { Jume } \\
\text { July }\end{array}$ & $\begin{array}{cc}26, & 1950 \\
5 & \\
13 & \end{array}$ & $\begin{array}{l}10.53 \\
12.68 \\
10.01\end{array}$ & $\begin{array}{l}\text { Aug. } 10,1950 \\
\text { Sept. } 12\end{array}$ & $\begin{array}{l}7.76 \\
8.48\end{array}$ & 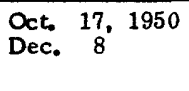 & $\begin{array}{l}7.96 \\
7.56\end{array}$ \\
\hline
\end{tabular}

$2-33-8 a d a$

\begin{tabular}{l|c|c||c|c||l|l|}
\hline Nov. 5, 1949 & 14.90 & Apr. 26, 1950 & 18.17 & Aug. 10, 1950 & 16.28 \\
Dec. 17 & 13.60 & June 5 & 21.72 & Sept. 12 & 14.68 \\
Feb. 2, 1950 & 12.15 & July 13 & 18.99 & Dec. 8 & 13.26 \\
Mar. 10 & 11.95 & & & & & \\
\hline
\end{tabular}

2-33-8dad

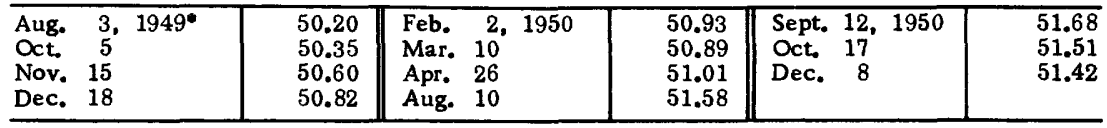

2-33-8dda

\begin{tabular}{l|r||lr|r||l|l|}
\hline Aug. 3, $1949^{*}$ & 46.20 & Feb. 2,1950 & 46.14 & Aug. 10, 1950 & 46.11 \\
Sept. & $2^{*}$ & 46.03 & Mar. 10 & 48.11 & Sept. 12 & 46.06 \\
Oct. 5 & 46.05 & Apr. 26 & 46.02 & Oct. 17 & 46.08 \\
Nov. 15 & 46.02 & Jume 5 & 5 & 46.15 & Dec. 8 & 46.08 \\
Dec. 18 & 46.10 & July 13 & 46.18 & & & \\
\hline
\end{tabular}

2-33-8ddd

\begin{tabular}{l|r||l|l||l|l|l}
\hline Aug. $3,1949^{*}$ & $\mathbf{5 5 . 3 0}$ & Feb. 2, 1950 & $\mathbf{5 5 . 4 5}$ & Aug. 10, 1950 & $\mathbf{5 5 . 3 4}$ \\
Sept. $2^{*}$ & $\mathbf{5 5 . 1 5}$ & Mar. 10 & $\mathbf{5 5 . 5 0}$ & Sept. 12 & $\mathbf{5 5 . 3 7}$ \\
Oct. 5 & $\mathbf{5 5 . 9 5}$ & Apr. 26 & $\mathbf{5 5 . 4 3}$ & Oct. 17 & $\mathbf{5 5 . 3 8}$ \\
Nov. 15 & $\mathbf{5 5 . 1 8}$ & June $\mathbf{5}$ & $\mathbf{5 5 . 4 8}$ & Dec. 8 & $\mathbf{5 5 . 4 5}$ \\
Dec. 17 & 55.29 & & & & & \\
\hline
\end{tabular}

$2-33-9 a c$

\begin{tabular}{l|l||l|l||lr|r}
\hline Feb. 8, 1949* & 27.50 & Oct. 5, 1949 & 27.67 & Jume 5, 1950 & 27.44 \\
Mar. 11* & 27.17 & Nov. 15 & 27.56 & July 13 & 27.61 \\
Apr. 28* & 27.28 & Dec. 18 & 27.52 & Aug. 10 & 27.65 \\
Jume 7* & 27.34 & Feb. 2, 1950 & 27.42 & Sept. 12 & 27.54 \\
July 5* & 27.30 & Mar. 10 & 27.21 & Oct. 17 & 27.56 \\
Aug. 3* & 27.62 & Apr. 26 & 27.31 & Dec. 8 & 27.53 \\
Sept. 2* & 27.78 & & & & \\
\hline
\end{tabular}

$2-33-9 a d$

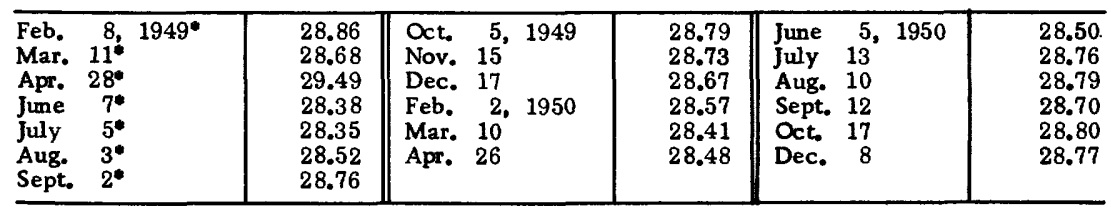


GROUND-WATER GEOLOGY, REPUBLICAN AND FRENCHMAN VALLEYS, NEBR. 667

Wat er-level measurements in wells, in feet below land-surface datum, with recorder chart readings of lowest daily water levels in 1950 - Continued

\begin{tabular}{c|c||c|c||c|c}
\hline Date & $\begin{array}{l}\text { Water } \\
\text { level }\end{array}$ & Date & $\begin{array}{l}\text { Water } \\
\text { level }\end{array}$ & Date & $\begin{array}{l}\text { Water } \\
\text { level }\end{array}$ \\
\hline
\end{tabular}

HITCHCOCK COUNTY-Continued

2-33-9bca 1

\begin{tabular}{|c|c|c|c|c|c|}
\hline $\begin{array}{l}\text { Jume } 30,1948^{\star} \\
\text { Aug. } 31^{\star} \\
\text { Sept. } 28^{\star} \\
\text { Oct. } 27^{\star} \\
\text { Dec. } 3^{\star} \\
\text { Feb. } 8^{*}, 1949^{\star} \\
\text { Mar. } 11^{\star} \\
\text { Apr. } 28^{\star}\end{array}$ & $\begin{array}{l}5.05 \\
5.05 \\
6.25 \\
5.25 \\
4.85 \\
3.99 \\
4.07 \\
4.22\end{array}$ & $\begin{array}{lrl}\text { June } & 7, & 1949 \\
\text { Aug. } & 3^{*} & \\
\text { Sept. } & 2^{*} & \\
\text { Oct. } & 6 & \\
\text { Dec. } & 17 & \\
\text { Feb. } & 2, & 1950 \\
\text { Mar. } & 10 & \end{array}$ & $\begin{array}{l}3.94 \\
8.90 \\
4.68 \\
5.36 \\
5.10 \\
4.22 \\
4.61\end{array}$ & $\begin{array}{lr}\text { Apr. } & 26,1950 \\
\text { Jume } & 5 \\
\text { July } & 13 \\
\text { Aug. } & 10 \\
\text { Sept. } & 12 \\
\text { Oct. } & 17 \\
\text { Dec. } & 8\end{array}$ & $\begin{array}{l}5.37 \\
6.04 \\
5.73 \\
4.81 \\
6.82 \\
5.45 \\
4.76\end{array}$ \\
\hline
\end{tabular}

2-33-9bca2

\begin{tabular}{l|r||l|l||lr|r}
\hline Feb. 8, 1949* & 15.50 & Oct. 6, 1949 & 16.35 & June 5, 1950 & 16.63 \\
Mar. 23* & 15.70 & Nov. 15 & 16.35 & July 13 & 17.08 \\
Apr. 28* & 15.69 & Dec. 18 & 16.37 & Aug. 10 & 16.53 \\
Jume $7^{*}$ & 15.59 & Feb. 2, 1950 & 15.68 & Sept. 12 & 17.10 \\
July 5* & 16.03 & Mar. 10 & 15.85 & Oct. 17 & 16.52 \\
Aug. 3* & 17.39 & Apr. 26 & - & 16.23 & Dec. 8 & 16.37 \\
Sept. 2* & 16.08 & & & & & \\
\hline
\end{tabular}

2-33-9bcd

\begin{tabular}{|c|c|c|c|c|c|}
\hline $\begin{array}{lr}\text { Feb. } & 8, \\
\text { Mar. } & 1941^{*} \\
\text { Apr. } & 28^{*} \\
\text { Jume } & 7^{*} \\
\text { July } & 5^{*} \\
\text { Aug. } & 3^{\star} \\
\text { Sept. } & 2^{*}\end{array}$ & $\begin{array}{l}19.95 \\
18.92 \\
19.19 \\
19.17 \\
19.34 \\
19.28 \\
19.34\end{array}$ & $\begin{array}{lrr}\text { Oct. } & 6, & 1949 \\
\text { Nov. } & 15 & \\
\text { Dec. } 17 & \\
\text { Feb. } & 2, & 1950 \\
\text { Mar. } 10 & \\
\text { Apr. } 26 & \end{array}$ & $\begin{array}{l}19.73 \\
20.05 \\
20.11 \\
19.78 \\
19.61 \\
19.96\end{array}$ & $\begin{array}{lr}\text { June } & 5,1950 \\
\text { July } & 13 \\
\text { Aug. } & 10 \\
\text { Sept. } & 12 \\
\text { Oct. } & 17 \\
\text { Dec. } & 8\end{array}$ & $\begin{array}{l}20.36 \\
20.82 \\
20.73 \\
18.92 \\
19.94 \\
20.10\end{array}$ \\
\hline
\end{tabular}

$2-33-9 b d$

\begin{tabular}{|c|c|c|c|c|c|c|c|}
\hline 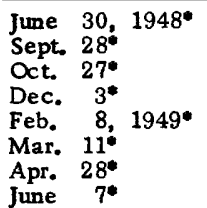 & $\begin{array}{l}13.72 \\
15.22 \\
14.55 \\
14.23 \\
13.21 \\
13.45 \\
13.50 \\
13.33\end{array}$ & $\begin{array}{lr}\text { July } & 5 \\
\text { Aug. } & 3 \\
\text { Sept. } & 2 \\
\text { Oct. } & 6 \\
\text { Nov. } & 15 \\
\text { Dec. } & 17 \\
\text { Feb. } & 2 \\
\text { Mar. } & 10\end{array}$ & $\begin{array}{ll}5, & 1949 \\
3 * & \\
2 & \\
6 & \\
5 & \\
7 & \\
2, & 1950 \\
0 & \end{array}$ & $\begin{array}{l}13.84 \\
15.05 \\
13.72 \\
14.05 \\
14.00 \\
13.90 \\
13.28 \\
13.55\end{array}$ & $\begin{array}{ll}\text { Apr. } & 2 \\
\text { June } & \\
\text { July } & 1 \\
\text { Aug. } & 1 \\
\text { Sept. } & 1 \\
\text { Oct. } & 1 \\
\text { Dec. } & \end{array}$ & $\begin{aligned} 26, & 1950 \\
5 & \\
13 & \\
10 & \\
12 & \\
17 & \\
8 & \end{aligned}$ & $\begin{array}{l}13.85 \\
14.13 \\
14.56 \\
13.89 \\
14.55 \\
14.20 \\
14.08\end{array}$ \\
\hline
\end{tabular}

$2-33-9 c b b$

\begin{tabular}{|c|c|c|c|c|c|}
\hline 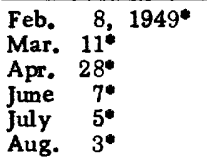 & $\begin{array}{l}20.00 \\
19.72 \\
19.48 \\
19.30 \\
19.34 \\
19.54\end{array}$ & $\begin{array}{ll}\text { Sept. } 2,1949 \\
\text { Oct. } 6 \\
\text { Nov. } 15 \\
\text { Dec. } 17 \\
\text { Mar. } 10,1950 \\
\text { Apr. } 26\end{array}$ & $\begin{array}{l}20.04 \\
21.25 \\
22.28 \\
22.19 \\
21.05 \\
22.94\end{array}$ & $\begin{array}{lrr}\text { June } & 5,1950 \\
\text { July } & 13 & \\
\text { Aug. } & 10 \\
\text { Sept, } & 12 \\
\text { Oct. } & 17 \\
\text { Dec. } & 8\end{array}$ & $\begin{array}{l}24.95 \\
25.40 \\
24.81 \\
23.61 \\
23.89 \\
22.30\end{array}$ \\
\hline
\end{tabular}

$2-33-9 c b c$

\begin{tabular}{l|r||lr|r||l|l|}
\hline Aug. 3, 1949* & 27.81 & Feb. 2,1950 & 28.43 & Aug. 10, 1950 & 28.92 \\
Sept. $2^{\star}$ & 27.79 & Mar. 10 & 28.37 & Sept. 12 & 28.88 \\
Oct. 6 & 27.95 & Apr. 26 & 28.48 & Oct. 17 & 28.80 \\
Nov. 15 & 28.17 & June 5 & 28.63 & Dec. 8 & 28.83 \\
Dec. 18 & 28.33 & July 13 & 28.79 & & & \\
\hline
\end{tabular}


Water-level measurements in wells, in feet below land-surface datum, with recorder chart readings of lowest daily water levels in 1950-Continued

\begin{tabular}{c|l||l|l||l|l|}
\hline Date & $\begin{array}{l}\text { Water } \\
\text { level }\end{array}$ & Date & $\begin{array}{l}\text { Water } \\
\text { level }\end{array}$ & $\begin{array}{l}\text { Water } \\
\text { level }\end{array}$ \\
\hline
\end{tabular}

HITCHCOCK COUNTY-Continued

2-33-10ab

\begin{tabular}{|c|c|c|c|c|c|c|c|}
\hline $\begin{array}{l}\text { Feb. } \\
\text { Apr } \\
\text { Jume } \\
\text { Aug. } \\
\text { Oct. } \\
\text { Dec. } \\
\text { Feb. } \\
\text { Apr. } \\
\text { Apr. }\end{array}$ & $\begin{array}{ll}2, & 1948 \\
9 & \\
7 & \\
2 & \\
4 & \\
6 & \\
7, & 1949 \\
6 & \\
28^{*} & \end{array}$ & $\begin{array}{l}7.24 \\
7.05 \\
7.80 \\
8.18 \\
8.72 \\
7.75 \\
6.80 \\
6.44 \\
6.75\end{array}$ & $\begin{array}{l}\text { June } \\
\text { July } \\
\text { Aug. } \\
\text { Sept. } \\
\text { Oct. } \\
\text { Nov. } \\
\text { Dec. } \\
\text { Feb. }\end{array}$ & $\begin{array}{rr}8, & 1949 \\
5 * & \\
3 & \\
2 & \\
6 & \\
15 & \\
17 & \\
2, & 1950\end{array}$ & $\begin{array}{l}6.69 \\
7.36 \\
7.97 \\
7.91 \\
7.75 \\
7.40 \\
7.26 \\
6.78\end{array}$ & $\begin{array}{lrl}\text { Mar. } & 10,1950 \\
\text { Apr. } & 26 \\
\text { June } & 5 \\
\text { July } & 13 \\
\text { Aug. } & 10 \\
\text { Sept. } & 12 \\
\text { Oct. } & 17 \\
\text { Dec. } & 8\end{array}$ & $\begin{array}{l}8.71 \\
6.83 \\
7.10 \\
7.83 \\
6.46 \\
7.26 \\
7.44 \\
7.13\end{array}$ \\
\hline
\end{tabular}

$2-34-7 c d$

\begin{tabular}{|c|c|c|c|c|c|c|c|c|}
\hline $\begin{array}{l}\text { Aug. } \\
\text { Oct. } \\
\text { Nov. } \\
\text { Dec. } \\
\text { Feb. }\end{array}$ & $\begin{array}{rr}3, & 1949 * \\
6 & \\
17 & \\
19 & \\
2, & 1950\end{array}$ & $\begin{array}{l}17.87 \\
18.40 \\
18.21 \\
18.04 \\
17.85\end{array}$ & $\begin{array}{l}\text { Mar. } \\
\text { Apr. } \\
\text { Jume } \\
\text { July }\end{array}$ & $\begin{array}{rr}10, & 1950 \\
26 & \\
5 & \\
13 & \end{array}$ & $\begin{array}{l}17.63 \\
17.50 \\
17.80 \\
18.56\end{array}$ & $\begin{array}{l}\text { Aug. } \\
\text { Sept. } 12 \\
\text { Oct. } 1 \\
\text { Dec. }\end{array}$ & $\begin{array}{ll}9, & 1950 \\
12 & \\
17 & \\
8 & \end{array}$ & $\begin{array}{l}18.32 \\
18.33 \\
18.19 \\
17.98\end{array}$ \\
\hline
\end{tabular}

$2-34-8 \mathrm{ad}$

\begin{tabular}{l|r|r||l||l|r|r}
\hline Oct. 5,1949 & 30.25 & Mar. 10, 1950 & 29.25 & Aug. 11, 1950 & 29.30 \\
Nov. 17 & 30.03 & Apr. 26 & 29.26 & Sept. 12 & 30.01 \\
Dec. 19 & 29.96 & Jume 5 & 29.48 & Oct. 17 & 29.80 \\
Feb. 2, 1950 & 29.53 & July 13 & 29.90 & Dec. 8 & 29.54 \\
\hline
\end{tabular}

$2-34-8 c b$

\begin{tabular}{l|l||lr|r||l|l|}
\hline Aug. $3,1949^{*}$ & 13.37 & Feb. 2,1950 & 13.64 & Aug. 9, 1950 & 13.49 \\
Sept. $7^{*}$ & 14.06 & Mar. 10 & 13.41 & Sept. 12 & 14.20 \\
Oct. 5 & 14.12 & Apr. 26 & 13.34 & Oct. 17 & 14.13 \\
Nov. 17 & 14.02 & June & 5 & 13.70 & Dec. 8 & 13.90 \\
Dec. 19 & 13.85 & July 13 & 13.99 & & & \\
\hline
\end{tabular}

$2-34-8 c d$

\begin{tabular}{|c|c|c|c|c|c|c|}
\hline $\begin{array}{l}\text { Aug. } \\
\text { Sept. } \\
\text { Oct. } \\
\text { Nov. } \\
\text { Dec. } 1\end{array}$ & $\begin{array}{rr}4, & 1949 \\
7 & \\
6 & \\
16 & \\
19 & \end{array}$ & $\begin{array}{l}5.95 \\
5.95 \\
5.92 \\
5.47 \\
5.28\end{array}$ & $\begin{array}{lr}\text { Feb. } & 2,1950 \\
\text { Mar. } & 10 \\
\text { Apr. } & 26 \\
\text { June } & 5\end{array}$ & $\begin{array}{l}4.85 \\
4.71 \\
4.81 \\
5.09\end{array}$ & $\begin{array}{lrl}\text { July } & 13, & 1950 \\
\text { Aug. } & 9 & \\
\text { Oct. } & 17 & \\
\text { Dec. } & 8 & \end{array}$ & $\begin{array}{l}5.50 \\
4.97 \\
5.61 \\
5.22\end{array}$ \\
\hline
\end{tabular}

$2-34-8 d a$

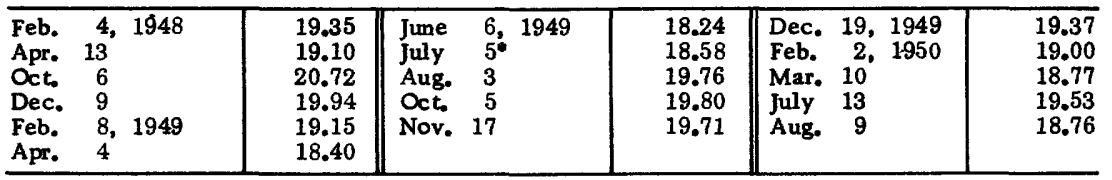

2-34-8db

\begin{tabular}{l|r||lr|r||l|l|}
\hline Aug. & $3,1949^{*}$ & 11.18 & Feb. 2,1950 & 10.91 & Aug. 9, 1950 & 10.60 \\
Sept. & $7^{*}$ & 11.73 & Mar. 10 & 10.62 & Sept. 12 & 11.52 \\
Oct. 5 & 11.70 & Apr. 26 & 10.73 & Oct. 17 & 11.51 \\
Nov. 17 & 11.45 & June 5 & 5 & 10.98 & Dec. 8 & 11.18 \\
Dec. 19 & 11.28 & July 13 & 11.30 & & & \\
\hline
\end{tabular}


GROUND-WATER GEOLOGY, REPUBLICAN AND FRENCHMAN VALLEYS, NEBR. 669

Water-level measurements in wells, in feet below land-surface datum, with recorder chart readings of lowest daily water levels in 1950 - Continued

\begin{tabular}{c|l|l|l||l|l}
\hline Date & $\begin{array}{l}\text { Water } \\
\text { level }\end{array}$ & Date & $\begin{array}{l}\text { Water } \\
\text { level }\end{array}$ & Date & $\begin{array}{l}\text { Water } \\
\text { level }\end{array}$ \\
\hline
\end{tabular}

HITCHCOCK COUNTY-Continued

2-34-11dc

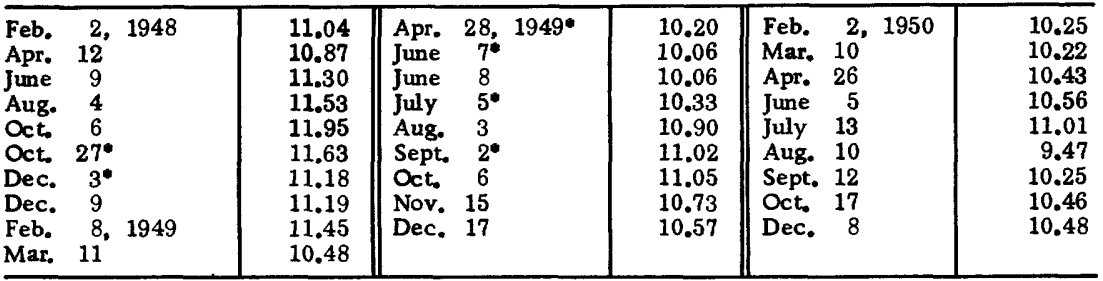

2-34-12da

\begin{tabular}{|c|c|c|c|c|c|c|c|}
\hline $\begin{array}{l}\text { Jume } \\
\text { Aug. } \\
\text { Sept. } \\
\text { Oct. } \\
\text { Dec. } \\
\text { Feb. } \\
\text { Mar. } \\
\text { Apr. }\end{array}$ & $\begin{array}{ll}30, & 1948^{\star} \\
31^{\star} & \\
28^{\star} & \\
27^{\star} & \\
3^{\star} & \\
8, & 1949^{\star} \\
11^{\star} & \\
28^{*} & \end{array}$ & $\begin{array}{l}15.10 \\
14.85 \\
15.70 \\
15.36 \\
15.48 \\
14.80 \\
14.42 \\
14.06\end{array}$ & $\begin{array}{l}\text { June } \\
\text { July } \\
\text { Aug. } \\
\text { Sept. } \\
\text { Oct. } \\
\text { Nov. } \\
\text { Dec. } \\
\text { Feb. }\end{array}$ & $\begin{array}{rr}7, & 1949^{*} \\
5 * & \\
3 & \\
2 & \\
6 & \\
15 & \\
17 & \\
2, & 1950\end{array}$ & $\begin{array}{l}13.75 \\
14.16 \\
15.22 \\
15.38 \\
15.01 \\
15.18 \\
15.10 \\
14.57\end{array}$ & $\begin{array}{lr}\text { Mar. } & 10,1950 \\
\text { Apr. } & 26 \\
\text { June } & 5 \\
\text { July } & 13 \\
\text { Aug. } & 10 \\
\text { Sept. } & 12 \\
\text { Oct. } & 17 \\
\text { Dec. } & 8\end{array}$ & $\begin{array}{l}14.44 \\
14.31 \\
14.25 \\
14.70 \\
14.06 \\
13.91 \\
14.16 \\
14.16\end{array}$ \\
\hline
\end{tabular}

$2-34-16 c c$

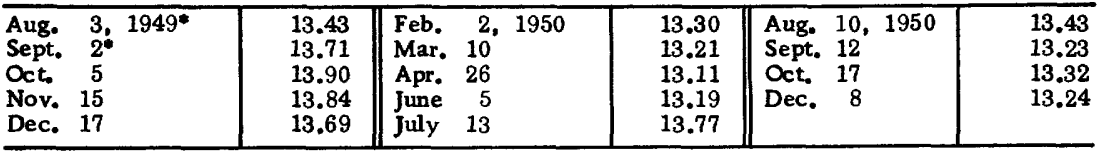

$2-34-16 d b$

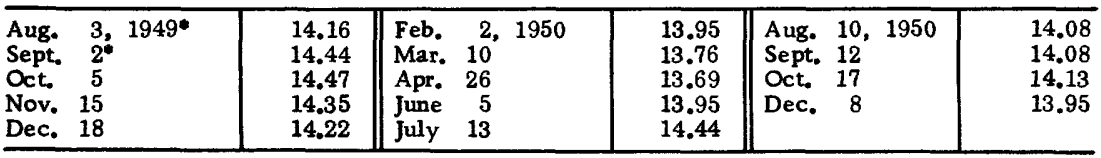

$2-34-17 b b$

\begin{tabular}{l|r||lr|r||lr|r}
\hline Aug. $3,1949^{*}$ & 14.55 & Feb. 2,1950 & 13.20 & Aug. 9, 1950 & 13.35 \\
Sept. $7^{*}$ & 14.06 & Mar. 10 & 12.98 & Sept. 12 & 14.75 \\
Oct. 5 & 13.94 & Apr. 26 & 13.67 & Oct. 17 & 13.77 \\
Nov. 15 & 13.85 & June 5 & 13.66 & Dec. 8 & 13.49 \\
Dec. 19 & 13.49 & July 13 & 13.81 & & & \\
\hline
\end{tabular}

$2-34-17 b c$

\begin{tabular}{l|r||rr|r||lr|r}
\hline Aug. $3,1^{1949^{\circ}}$ & 8.81 & Feb. 2,1950 & 8.80 & Aug. 9,1950 & 9.06 \\
Sept. & 8.52 & Mar. 10 & 8.88 & Sept. 12 & 9.32 \\
Oct. 5 & 5 & 9.60 & Apr. 26 & 8.78 & Oct. 17 & 9.34 \\
Nov. 15 & 9.40 & June & 5 & 9.14 & Dec. 8 & 9.07 \\
Dec. 19 & 9.20 & July 13 & 9.49 & & & \\
\hline
\end{tabular}


Water-level measurements in wells, in feet below land-surface datum, with recorder chart readings of lowest daily water levels in 1950 - Continued

\begin{tabular}{c|c||c|c||c|c}
\hline Date & $\begin{array}{l}\text { Water } \\
\text { level }\end{array}$ & Date & $\begin{array}{l}\text { Water } \\
\text { level }\end{array}$ & Date & $\begin{array}{l}\text { Water } \\
\text { level }\end{array}$ \\
\hline
\end{tabular}

HITCHCOCK COUNTY-Continued

$2-34-18 a b$

\begin{tabular}{l|l||lr|r||l|r|r}
\hline Aug. $3,1949^{*}$ & 17.90 & Feb. 2,1950 & 17.52 & Aug. 9, 1950 & 18.11 \\
Sept. $7^{*}$ & 18.27 & Mar. 10 & & 17.30 & Sept. 12 & 18.31 \\
Oct. 5 & 18.17 & Apr. 26 & 17.24 & Oct. 17 & 18.12 \\
Nov. 17 & 17.94 & June & 5 & 17.69 & Dec. 8 & 17.85 \\
Dec. 19 & 17.77 & July 13 & & 18.67 & & \\
\hline
\end{tabular}

$2-34-18 a c b$

\begin{tabular}{l|l||lr|r||l|l|l}
\hline Aug. $3,1949^{*}$ & 21.22 & Feb. 2,1950 & 20.12 & Aug. 9, 1950 & 20.78 \\
Sept. $7^{\star}$ & 21.03 & Mar. 10 & & 20.02 & Sept. 12 & 21.12 \\
Oct. 5 & 20.87 & Apr. 26 & 20.06 & Oct. 17 & 20.67 \\
Nov. 17 & 20.62 & June 5 & 20.45 & Dec. 8 & 20.55 \\
Dec. 19 & 20.50 & July 13 & & 21.33 & & \\
\hline
\end{tabular}

2-34-18acc

\begin{tabular}{l|r||lr|r||l|l|l}
\hline Aug. $3,1949^{*}$ & 8.61 & Feb. 2, 1950 & 7.86 & Aug. 9, 1950 & 8.58 \\
Sept. $7^{*}$ & 8.30 & Mar. 10 & 8.08 & Sept. 12 & 8.85 \\
Oct. 5 & 8.65 & Apr. 26 & 8.13 & Oct. 17 & 8.69 \\
Nov. 17 & 8.42 & Jume 5 & 8.38 & Dec. 8 & 8.43 \\
Dec. 19 & 8.31 & July 13 & 8.89 & & & \\
\hline
\end{tabular}

$2-34-18 b b$

\begin{tabular}{|c|c|c|c|c|c|}
\hline 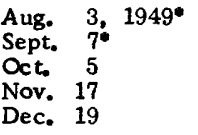 & $\begin{array}{l}24.94 \\
25.11 \\
24.44 \\
24.09 \\
23.82\end{array}$ & $\begin{array}{lrl}\text { Feb. } & 2,1950 \\
\text { Mar. } & 10 & \\
\text { Apr. } & 26 & \\
\text { Jume } & 5 & \\
\text { July } & 13 & \end{array}$ & $\begin{array}{l}23.52 \\
23.27 \\
23.55 \\
24.27 \\
24.22\end{array}$ & $\begin{array}{lr}\text { Aug. } & 9,1950 \\
\text { Sept. } & 12 \\
\text { Oct. } 17 \\
\text { Dec. } 8\end{array}$ & $\begin{array}{l}24.47 \\
25.30 \\
24.54 \\
23.99\end{array}$ \\
\hline
\end{tabular}

$2-34-18 b c$

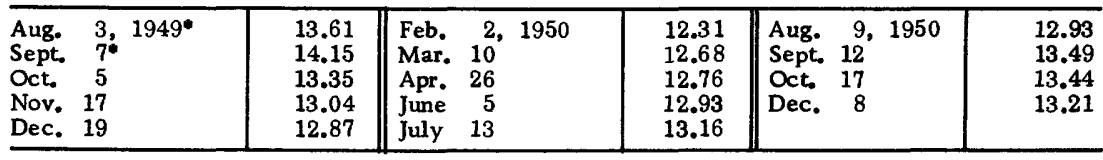

$2-34-19 a a$

\begin{tabular}{l|r||lr|r||lr|r}
\hline Aug. $3,1949^{\bullet}$ & 10.88 & Feb. 2,1950 & 10.27 & Aug. 10, 1950 & 9.55 \\
Sept. $2^{*}$ & 10.84 & Mar. 10 & 10.19 & Sept. 12 & 10.39 \\
Oct. 5 & 5 & 10.98 & Apr. 26 & 10.20 & Oct. 17 & 10.47 \\
Nov. 17 & 10.57 & June & 5 & 10.28 & Dec. 8 & 10.28 \\
Dec. 19 & 10.41 & July 13 & 10.85 & & & \\
\hline
\end{tabular}

$2-34-19 a b$

\begin{tabular}{l|r||l|l||l|l|l}
\hline Aug. $3,1949^{*}$ & 3.73 & Feb. 2, 1950 & 2.44 & July 13, 1950 & 3.25 \\
Sept. $2^{*}$ & 3.68 & Mar. 10 & 2.11 & Sept. 12 & 2.96 \\
Oct. 5 & 3.55 & Apr. 26 & 2.33 & Oct. 17 & 2.88 \\
Nov. 17 & 2.92 & June 5 & 2.34 & Dec. 8 & 3.49 \\
Dec. 19 & 2.74 & & & & & \\
\hline
\end{tabular}


GROUND-WATER GEOLOGY, REPUBLICAN AND FRENCHMAN VALLEYS, NEBR. 671

Water-level measurements in wells, in feet below land-surtace datum, with recorder chart readings of lowest daily water levels in 1950 - Continued

\begin{tabular}{c|l|l|l|l|l|l|l|l|l|}
\hline Date & $\begin{array}{l}\text { Water } \\
\text { level }\end{array}$ & Date & $\begin{array}{l}\text { Water } \\
\text { level }\end{array}$ & Date \\
\hline
\end{tabular}

HITCHCOCK COUNTY-Continued

\begin{tabular}{|c|c|c|c|c|c|c|c|c|}
\hline \multicolumn{9}{|c|}{$2-34-19 a c b$} \\
\hline $\begin{array}{l}\text { Aug. } \\
\text { Sept. } \\
\text { Oct. } \\
\text { Nov. } 1 \\
\text { Dec. } 1\end{array}$ & $\begin{array}{l}3.1949 \\
2 \\
5 \\
17 \\
19\end{array}$ & $\begin{array}{l}6.05 \\
6.06 \\
5.94 \\
5.37 \\
5.17\end{array}$ & $\begin{array}{l}\text { Feb. } \\
\text { Mar. } \\
\text { Apr. } \\
\text { June } \\
\text { July }\end{array}$ & $\begin{array}{rr}2, & 1950 \\
10 & \\
26 & \\
5 & \\
13 & \end{array}$ & $\begin{array}{l}5.00 \\
4.66 \\
4.79 \\
4.83 \\
5.76\end{array}$ & $\begin{array}{l}\text { Aug. } 1 \\
\text { Sept. } 1 \\
\text { Oct. } 1 \\
\text { Dec. }\end{array}$ & $\begin{array}{rr}10, & 1950 \\
12 & \\
17 & \\
8 & \end{array}$ & $\begin{array}{l}2.26 \\
5.29 \\
5.31 \\
4.98\end{array}$ \\
\hline
\end{tabular}

$2-34-19 a c c$

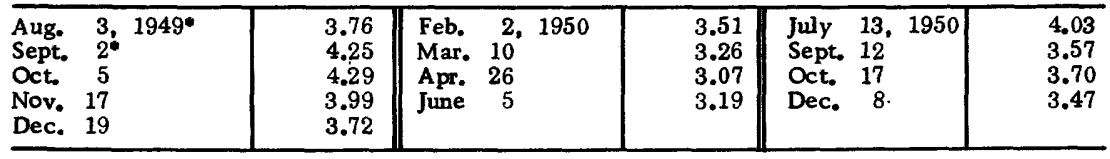

2-34-19bb

\begin{tabular}{l|r||lr|r||l|l|}
\hline Aug. $3,1949^{*}$ & 9.05 & Feb. 2,1950 & 7.72 & Aug. 9, 1950 & 6.99 \\
Sept. & $2 *$ & 8.38 & Mar. 10 & 7.35 & Sept. 12 & 8.31 \\
Oct. 5 & 8.87 & Apr. 26 & 7.54 & Oct. 17 & 8.28 \\
Nov. 17 & 8.22 & Jume & 5 & 7.51 & Dec. 8 & 7.91 \\
Dec. 19 & 7.99 & July 13 & 8.57 & & & \\
\hline
\end{tabular}

$2-34-20 a b$

\begin{tabular}{|c|c|c|c|c|c|}
\hline $\begin{array}{lrl}\text { Aug. } & 3, & 1949^{*} \\
\text { Sept. } & 2 & \\
\text { Oct. } & 5 \\
\text { Nov. } & 17 \\
\text { Dec. } & 19\end{array}$ & $\begin{array}{l}26.75 \\
27.15 \\
27.32 \\
27.16 \\
.26 .97\end{array}$ & $\begin{array}{lrr}\text { Feb. } & 2, & 1950 \\
\text { Mar. } & 10 \\
\text { Apr. } & 26 \\
\text { June } & 5 \\
\text { July } & 13\end{array}$ & $\begin{array}{l}26.75 \\
26.53 \\
26.39 \\
26.49 \\
27.10\end{array}$ & $\begin{array}{lrr}\text { Aug. } & 10, & 1950 \\
\text { Sept. } & 12 & \\
\text { Oct. } & 17 & \\
\text { Dec. } & 8 & \end{array}$ & $\begin{array}{l}26.73 \\
26.59 \\
26.74 \\
26.55\end{array}$ \\
\hline
\end{tabular}

2-34-20bbc

\begin{tabular}{|c|c|c|c|c|c|}
\hline $\begin{array}{lrl}\text { Sept. } & 2,1949^{*} \\
\text { Oct. } & 5 \\
\text { Nov. } & 17 \\
\text { Dec. } 19 & \\
\end{array}$ & $\begin{array}{l}7.96 \\
7.91 \\
7.38 \\
7.23\end{array}$ & $\begin{array}{lr}\text { Feb. } & 2,1950 \\
\text { Mar. } & 10 \\
\text { Apr. } & 26 \\
\text { June } \quad 5 & \end{array}$ & $\begin{array}{l}7.11 \\
7.04 \\
7.09 \\
7.17\end{array}$ & $\begin{array}{lrl}\text { July } & 13, & 1950 \\
\text { Oct. } & 17 & \\
\text { Dec. } & 8\end{array}$ & $\begin{array}{l}7.74 \\
7.35 \\
7.17\end{array}$ \\
\hline \multicolumn{6}{|c|}{$2-34-20 b b d$} \\
\hline $\begin{array}{ll}\text { Aug. } & 3,1949^{*} \\
\text { Sept. } & 2 \\
\text { Oct. } 5 \\
\text { Nov. } 17 \\
\text { Dec. } 19\end{array}$ & $\begin{array}{l}9.03 \\
9.37 \\
9.34 \\
8.82 \\
8.62\end{array}$ & $\begin{array}{lr}\text { Feb. } & 2,1950 \\
\text { Mar. } & 10 \\
\text { Apr. } & 26 \\
\text { June } & 5 \\
\text { July } & 13\end{array}$ & $\begin{array}{l}8.48 \\
8.29 \\
8.21 \\
8.38 \\
9.07\end{array}$ & $\begin{array}{lrr}\text { Aug. } & 10, & 1950 \\
\text { Sept. } & 12 & \\
\text { Oct. } & 17 & \\
\text { Dec. } & 8 & \end{array}$ & $\begin{array}{l}7.66 \\
8.71 \\
8.69 \\
8.37\end{array}$ \\
\hline
\end{tabular}

$2-35-12 d c$

\begin{tabular}{|c|c|c|c|c|c|c|c|}
\hline $\begin{array}{l}\text { Aug. } \\
\text { Sept. } \\
\text { Oct. } \\
\text { Nov. } 1 \\
\text { Dec. } 1\end{array}$ & $\begin{array}{l}3,1949^{*} \\
2 \\
5 \\
17 \\
19\end{array}$ & $\begin{array}{l}23.44 \\
23.99 \\
21.95 \\
23.67 \\
23.45\end{array}$ & $\begin{array}{l}\text { Feb. } \\
\text { Mar. } 1 \\
\text { Apr. } 2 \\
\text { Jume } \\
\text { July } 1\end{array}$ & $\begin{array}{rr}2, & 1950 \\
10 & \\
26 & \\
5 & \\
13 & \end{array}$ & $\begin{array}{l}23.12 \\
22.90 \\
22.91 \\
23.06 \\
23.42\end{array}$ & 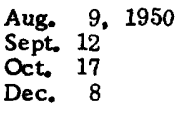 & $\begin{array}{l}23.31 \\
23.24 \\
23.84 \\
23.54\end{array}$ \\
\hline
\end{tabular}


Water-level measurements in wells, in feet below land-surface datum, with recorder chart readings of lowest deily water levels in 1950-Continued

\begin{tabular}{c|c||l|l||l|l}
\hline Date & $\begin{array}{l}\text { Water } \\
\text { level }\end{array}$ & Date & $\begin{array}{l}\text { Water } \\
\text { level }\end{array}$ & Date & $\begin{array}{l}\text { Water } \\
\text { level }\end{array}$ \\
\hline
\end{tabular}

HITCHCOCK COUNTY-Continued

2-35-12dd

\begin{tabular}{l|r||lr|r||l|l|}
\hline Aug. $3,1949^{*}$ & 25.78 & Feb. 2,1950 & 25.01 & Aug. 9, 1950 & 25.61 \\
Sept. & $7^{*}$ & 26.55 & Mar. 10 & 24.79 & Sept. 12 & 26.18 \\
Oct. 5 & 25.92 & Apr. 26 & 24.82 & Oct. 17 & 25.66 \\
Nov. 17 & 25.52 & June & 5 & 25.28 & Dec. 8 & 25.28 \\
Dec. 19 & 25.30 & July 13 & 25.53 & & & \\
\hline
\end{tabular}

2-35-13bba

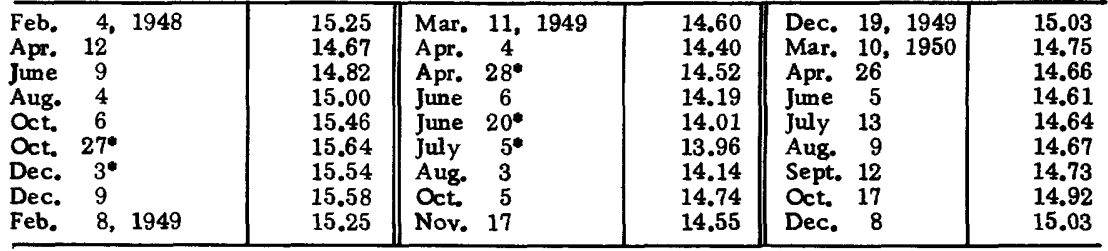

$2-35-13 b b c$

\begin{tabular}{l|r||lr|r||l|l|l}
\hline Aug. & $3,1949^{*}$ & 19.17 & Feb. 2,1950 & 19.28 & Aug. 9, 1950 & 19.51 \\
Sept. & $2 *$ & 19.99 & Mar. 10 & 19.01 & Sept. 12 & 19.82 \\
Oct. & 5 & 20.10 & Apr. 26 & 18.94 & Oct. 17 & 20.01 \\
Nov. 17 & 19.81 & June & 5 & 19.03 & Dec. 8 & 19.74 \\
Dec. 19 & 19.59 & July 13 & 19.65 & & & \\
\hline
\end{tabular}

2-35-13bd

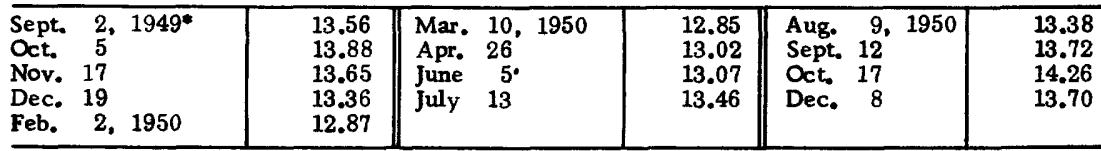

$2-35-13 c c$

\begin{tabular}{l|r||lr|r||lr|r}
\hline Aug. 3, 1949* & 11.14 & Feb. 2,1950 & 10.86 & July & 13,1950 & 11.38 \\
Oct. 5 & 11.49 & Mar. 10 & & 10.60 & Aug. 9 & & 11.20 \\
Nov. 17 & 11.32 & Apr. 26 & 10.46 & Oct. 17 & 11.49 \\
Dec. 19 & 11.13 & June & 5 & 10.57 & Dec. & 8 & 11.15 \\
\hline
\end{tabular}

$2-35-13 c d$

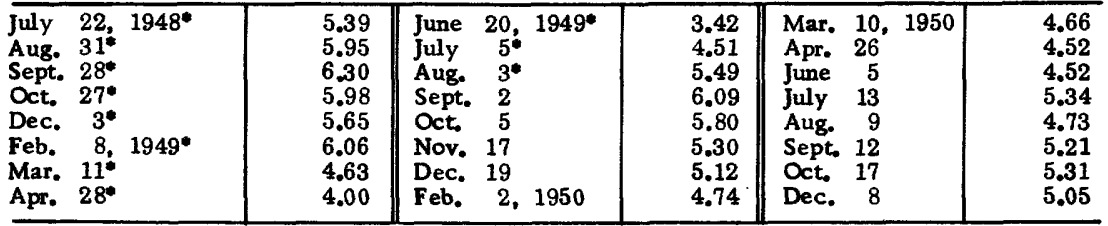

2-35-13dc

\begin{tabular}{ll|l||l|l|l|l|l|}
\hline Aug. & $3,1949^{*}$ & 7.98 & Oct. 5,1949 & 8.56 & Dec. 19, 1949 & 7.90 \\
Sept. & $2^{*}$ & 8.56 & Nov. 17 & & 8.10 & Feb. 2,1950 & 7.57
\end{tabular}


GROUND-WATER GEOLOGY, REPUBLICAN AND FRENCHMAN VALLEYS, NEBR. 673

Water-level measurements in wells, in feet below land-surface datum, with recorder chart readings of lowest daily water levels in 1950-Continued

\begin{tabular}{c|l||l|l||l|l}
\hline Date & $\begin{array}{l}\text { Water } \\
\text { level }\end{array}$ & Date & $\begin{array}{l}\text { Water } \\
\text { level }\end{array}$ & Date & $\begin{array}{l}\text { Water } \\
\text { level }\end{array}$ \\
\hline
\end{tabular}

HITCHCOCK COUNTY-Continued

2-35-13dc-Continued

\begin{tabular}{|c|c|c|c|c|c|}
\hline 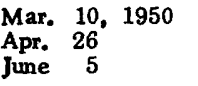 & $\begin{array}{l}7.33 \\
7.30 \\
7.30\end{array}$ & $\begin{array}{lrl}\text { July } & 13, & 1950 \\
\text { Aug. } & 9 \\
\text { Sept. } 12 & \end{array}$ & $\begin{array}{l}8.11 \\
6.93 \\
7.84\end{array}$ & $\begin{array}{lcl}\text { Oct. } & 17, & 1950 \\
\text { Dec. } & 8 & \end{array}$ & $\begin{array}{l}8.00 \\
7.79\end{array}$ \\
\hline \multicolumn{6}{|c|}{$2-35-19 \mathrm{ca}$} \\
\hline $\begin{array}{l}\text { Oct. } 27,1948^{\star} \\
\text { Dec. } 3^{\star} \\
\text { Apr. } 28,1949^{*} \\
\text { Jume } 20^{\star}\end{array}$ & $\begin{array}{r}10.22 \\
9.88 \\
8.35 \\
7.70\end{array}$ & $\begin{array}{lrl}\text { July } & 6,1949^{*} \\
\text { Sept. } & 13^{*} \\
\text { Aug. } & 29,1950\end{array}$ & $\begin{array}{l}7.28 \\
9.23 \\
9.27\end{array}$ & $\begin{array}{lcc}\text { Sept. } & 20, & 1950 \\
\text { Oct. } & 24 & \\
\text { Dec. } & 8 & \end{array}$ & $\begin{array}{l}9.55 \\
9.63 \\
9.29\end{array}$ \\
\hline
\end{tabular}

$2-35-21 b c$

\begin{tabular}{|c|c|c|c|c|c|c|}
\hline $\begin{array}{l}\text { Feb. } \\
\text { Apr. } \\
\text { June } \\
\text { Aug. } \\
\text { Oct. } \\
\text { Dec. } \\
\text { Feb. } \\
\text { Apr. }\end{array}$ & $\begin{array}{rr}4, & 1948 \\
12 & \\
9 & \\
4 & \\
6 & \\
9 & \\
8, & 1949 \\
4 & \end{array}$ & $\begin{array}{l}20.28 \\
20.50 \\
20.61 \\
20.75 \\
21.11 \\
20.83 \\
20.80 \\
20.40\end{array}$ & $\begin{array}{lrl}\text { June } & 6,1949 \\
\text { Aug. } & 3 \\
\text { Sept. } & 13^{*} & \\
\text { Oct. } & 5 \\
\text { Nov. } & 17 \\
\text { Dec. } & 19 & \\
\text { Jan. } & 17, & 1950\end{array}$ & $\begin{array}{l}19.77 \\
19.79 \\
20.08 \\
20.18 \\
20.22 \\
20.17 \\
20.18\end{array}$ & $\begin{array}{lrl}\text { Feb. } & 28, & 1950 \\
\text { Apr. } & 14 \\
\text { Jume } & 2 \\
\text { July } & 12 \\
\text { Aug. } & 10 \\
\text { Sept. } & 20 \\
\text { Oct. } & 24\end{array}$ & $\begin{array}{l}20.00 \\
19.96 \\
19.96 \\
20.15 \\
19.80 \\
20.13 \\
20.24\end{array}$ \\
\hline
\end{tabular}

2-35-23aa

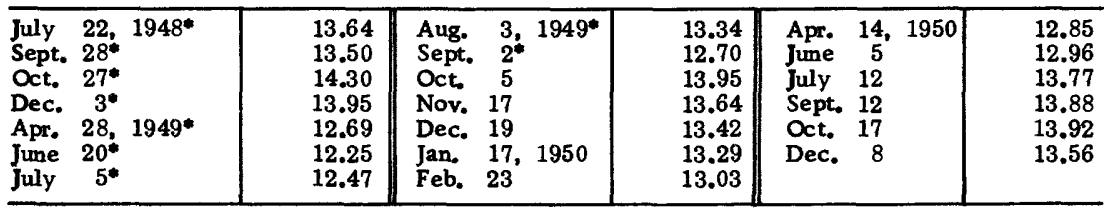

$2-35-23 c b$

\begin{tabular}{l|l||l|l|l|l|}
\hline July 22, 1948* & 28.13 & Mar. 11, 1949* & 27.85 & Sept. 2, 1949* & 27.38 \\
Aug. 31* & 28.45 & Apr. 28* & 27.69 & Oct. 5 & 29.05 \\
Sept. 28* & 28.65 & June 20* & 26.93 & Nov. 17 & 28.00 \\
Oct. 27* & 28.58 & July 5* & 27.15 & Dec. 19 & 27.89 \\
Dec. 3* & 28.40 & Aug. $3^{*}$ & 27.69 & Jan. 17, 1950 & 27.82 \\
\hline
\end{tabular}

2-35-24aa

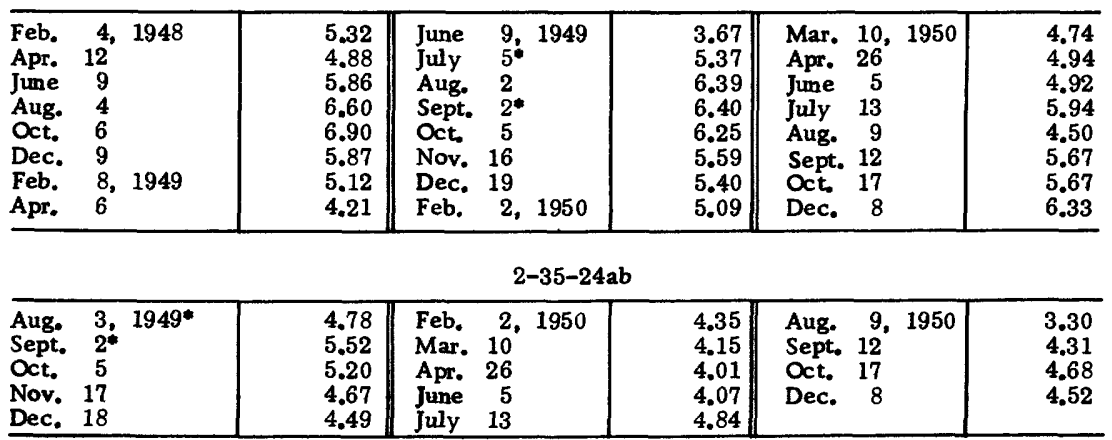


Water-level measurements in wells, in feet below land-surface dstum, with recorder chart readings of lowest daily water levels in 1950-Continued

\begin{tabular}{c|c||c|c||c|c}
\hline Date & $\begin{array}{l}\text { Water } \\
\text { level }\end{array}$ & Date & $\begin{array}{l}\text { Water } \\
\text { level }\end{array}$ & Date & $\begin{array}{l}\text { Water } \\
\text { level }\end{array}$ \\
\hline
\end{tabular}

HITCHCOCK COUNTY-Continued

2-35-24ada

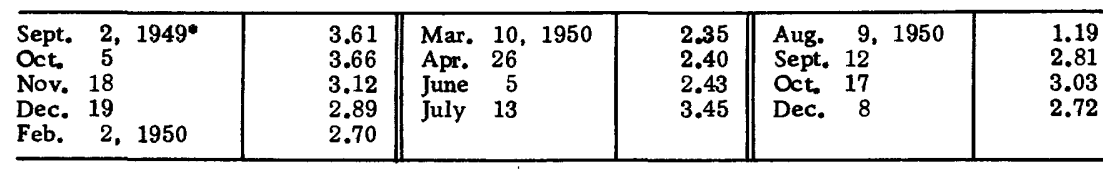

2-35-24add

\begin{tabular}{lr|r||lr|r||rr|r|}
\hline Aug. $3,1949^{\circ}$ & 3.40 & Feb. 2,1950 & 7.84 & June & 5,1950 & 7.49 \\
Oct. 5 & 8.58 & Mar. 10 & & 7.61 & Sept. & 12 & 7.73 \\
Nov. 17 & 8.31 & Apr. 26 & 7.62 & Dec. & 8 & 7.86 \\
Dec. 19 & 8.03 & & & & & & \\
\hline
\end{tabular}

2-35-24bc

\begin{tabular}{l|r||l|l||l|l|l}
\hline Aug. 3, 1949* & 17.48 & Feb. 2, 1950 & 17.80 & Aug. 9, 1950 & 18.07 \\
Sept. $2^{*}$ & 17.91 & Mar. 10 & 17.65 & Sept. 12 & 18.11 \\
Oct. 5 & 18.12 & Apr. 26 & 17.50 & Oct. 17 & 18.03 \\
Nov. 17 & 18.08 & June 5 & 17.48 & Dec. 8 & 17.91 \\
Dec. 19 & 17.98 & July 13 & 17.95 & & & \\
\hline
\end{tabular}

$3-31-7 c d$

\begin{tabular}{l|l||l|l||l|l|l}
\hline July 10,1950 & 12.15 & Sept. 19,1950 & 11.69 & Dec. 6, 1950 & 11.72 \\
Aug. 9 & 11.62 & Oct. 18 & 12.00 & & \\
\hline
\end{tabular}

3-31-9dd

\begin{tabular}{l|r||l|r||rr|r|}
\hline July 10,1950 & 12.06 & Sept. 19,1950 & 10.49 & Dec. 6, 1950 & 10.52 \\
Aug. 11 & 11.95 & Oct. 18 & 8.95 & & \\
\hline
\end{tabular}

$3-31-13 c b$

\begin{tabular}{l|l||l|l||l|l|l}
\hline July 10, 1950 & 4.28 & Sept. 18, 1950 & 3.79 & Dec. 6, 1950 & 3.37 \\
Aug. 11 & 4.02 & Oct. 18 & 3.59 & & \\
\hline
\end{tabular}

$3-31-14 \mathrm{ab}$

\begin{tabular}{l|l|l||l|l||l|l|}
\hline July 10,1950 & $\mathbf{2 2 . 6 9}$ & Sept. 18, 1950 & 21.60 & Dec. 6, 1950 & 21.24 \\
Aug. 9 & 22.32 & Oct. 18 & 21.25 & & \\
\hline
\end{tabular}

$3-31-14 b c$

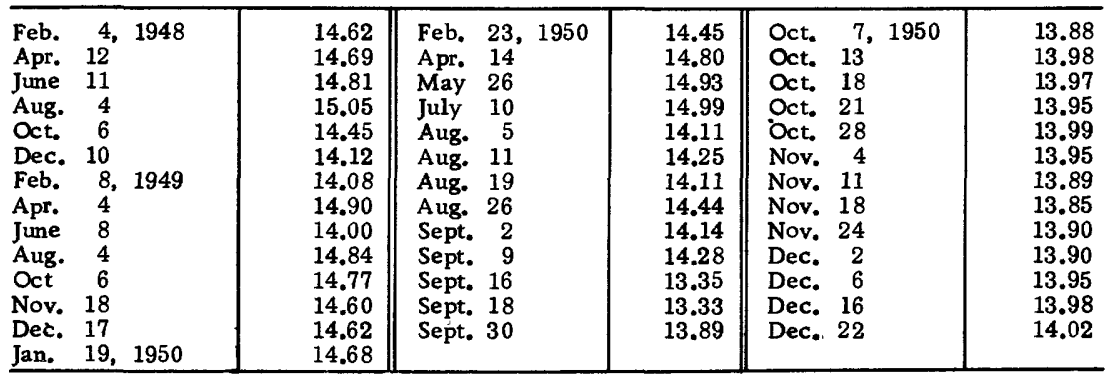


ǴROUND-WATER GEOLOGY, REPUBLICAN AND FRENCHMAN VALLEYS, NEBR. 675

Water-level measurements in wells, in feet jelow land-surface datum, with recorder chart readings of lowest daily water levels in 1950-Continued

\begin{tabular}{c|c||c|c||c|c}
\hline Date & $\begin{array}{l}\text { Water } \\
\text { level }\end{array}$ & Date & $\begin{array}{l}\text { Water } \\
\text { level }\end{array}$ & Date & $\begin{array}{l}\text { Water } \\
\text { level }\end{array}$ \\
\hline
\end{tabular}

HITCHCOCK COUNTY-Continued

3-31-15cc2

\begin{tabular}{l|l||l|l||l|l|}
\hline June 19,1950 & 5.31 & Sept. 22, 1950 & 5.02 & Dec. 7, 1950 & 4.98 \\
Aug. 13 & 4.76 & Oct. 20 & 5.09 & & \\
\hline
\end{tabular}

$3-31-17 \mathrm{~cd}$

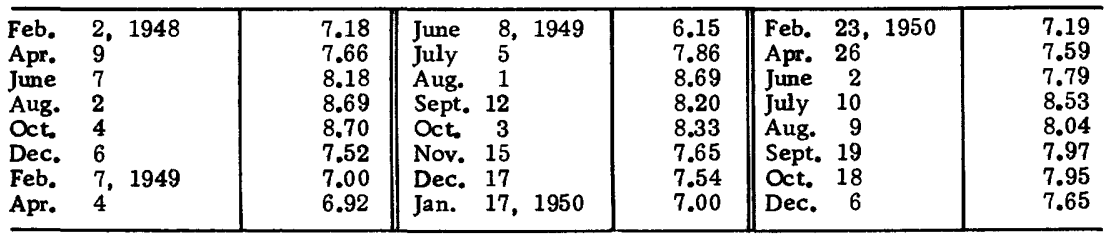

3-31-20ad

\begin{tabular}{ll|l||l|l||lr|r}
\hline June 19,1950 & 7.44 & Aug. 12, 1950 & 7.30 & Oct. 20, 1950 & 7.67 \\
July 14 & 7.87 & Sept. 22 & 7.69 & Dec. 7 & 7.53 \\
\hline
\end{tabular}

$3-31-20 \mathrm{cc}$

\begin{tabular}{|l|l||l|l||l|l|l}
\hline June & 19,1950 & 10.20 & Aug. 12, 1950 & 9.40 & Oct. 20, 1950 & 10.10 \\
July 14 & 10.57 & Sept. 22 & 9.91 & Dec. 7 & 10.02 \\
\hline
\end{tabular}

3-31-20da

\begin{tabular}{|c|c|c|c|c|c|c|c|}
\hline $\begin{array}{l}\text { Feb. } \\
\text { Apr. } \\
\text { June } \\
\text { Aug. } \\
\text { Oct. } \\
\text { Dec. } \\
\text { Feb. } \\
\text { Apr. }\end{array}$ & $\begin{array}{ll}2, & 1948 \\
9 & \\
7 & \\
2 & \\
4 & \\
6 & \\
7, & 1949 \\
4 & \end{array}$ & $\begin{array}{l}8.10 \\
7.94 \\
7.85 \\
8.12 \\
8.40 \\
8.52 \\
8.42 \\
8.15\end{array}$ & $\begin{array}{l}\text { June } \\
\text { July } \\
\text { Aug. } \\
\text { Sept. } 1 \\
\text { Oct. } \\
\text { Nov. } 1 \\
\text { Dec. } 1 \\
\text { Jan. } 1\end{array}$ & $\begin{array}{rr}8, & 1949 \\
5 & \\
1 & \\
12 & \\
3 & \\
15 & \\
17 & \\
17, & 1950\end{array}$ & $\begin{array}{l}7.33 \\
7.46 \\
7.92 \\
8.18 \\
8.45 \\
8.25 \\
8.29 \\
8.24\end{array}$ & 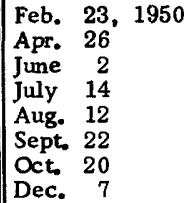 & $\begin{array}{l}8.15 \\
8.01 \\
7.93 \\
8.30 \\
6.98 \\
7.82 \\
8.00 \\
8.04\end{array}$ \\
\hline
\end{tabular}

3-31-21cc

\begin{tabular}{|l|l||l|l||lr|r}
\hline June & 19,1950 & 15.91 & Aug. 13, 1950 & 15.58 & Oct, 20, 1950 & 15.87 \\
July 14 & 16.06 & Sept. 22 & 15.78 & Dec. & 7 & 15.91 \\
\hline
\end{tabular}

3-31-22ba

\begin{tabular}{ll|l||l|l||lr|r|r}
\hline June & 19,1950 & 4.85 & Aug. 12, 1950 & 4.41 & Oct. 20, 1950 & 4.91 \\
July 14 & 4.96 & Sept. 22 & 4.60 & Dec. 7 & 4.85 \\
\hline
\end{tabular}

3-31-22bb

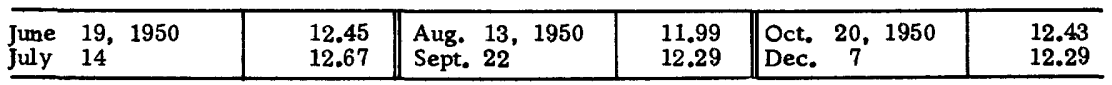

$3-31-22 b c$

\begin{tabular}{|l|l||l|l||lr|r|}
\hline June & 19,1950 & 28.25 & Aug. 13, 1950 & 28.03 & Oct. 20, 1950 & 28.27 \\
July 14 & 28.39 & Sept. 22 & 28.18 & Dec. 7 & $\mathbf{2 8 . 2 8}$ \\
\hline
\end{tabular}


Water-level measurements in wells, in feet below land-surface datum, with recorder chart readings of lowest daily water levels in 1950-Continued

\begin{tabular}{c|l||l|l||l|l|}
\hline Date & $\begin{array}{l}\text { Water } \\
\text { level }\end{array}$ & Date & $\begin{array}{l}\text { Water } \\
\text { level }\end{array}$ & $\begin{array}{l}\text { Water } \\
\text { level }\end{array}$ \\
\hline
\end{tabular}

HITCHCOCK COUNTY-Continued

$$
\text { 3-31-22da }
$$

\begin{tabular}{|c|c|c|c|c|c|c|}
\hline June & $\begin{array}{l}19,1950 \\
14\end{array}$ & $\begin{array}{l}10.73 \\
10.88\end{array}$ & $\begin{array}{l}\text { Aug. 13, } 1950 \\
\text { Sept. } 22\end{array}$ & $\begin{array}{l}10.38 \\
10.66\end{array}$ & $\begin{array}{lll}\text { Oct. } & 20,1950 \\
\text { Dec. } & 7\end{array}$ & $\begin{array}{l}10.86 \\
10.82\end{array}$ \\
\hline \multicolumn{7}{|c|}{$3-31-23 a d$} \\
\hline $\begin{array}{l}\text { Jume } \\
\text { July }\end{array}$ & $\begin{array}{l}19,1950 \\
14\end{array}$ & $\begin{array}{r}9.99 \\
10.40\end{array}$ & $\begin{array}{l}\text { Aug. 13, } 1950 \\
\text { Sept. } 22\end{array}$ & $\begin{array}{r}9.88 \\
10.44\end{array}$ & $\begin{array}{l}\text { Oct. } 20,1950 \\
\text { Dec. } 7\end{array}$ & $\begin{array}{l}10.63 \\
10.64\end{array}$ \\
\hline
\end{tabular}

$3-31-23 b b$

\begin{tabular}{|l|l||l|l||l|l|l|}
\hline June 19,1950 & 5.48 & Aug. 13, 1950 & 5.56 & Oct. 20, 1950 & 6.02 \\
July 14 & 5.67 & Sept. 22 & 5.78 & Dec. 7 & 5.94 \\
\hline
\end{tabular}

\section{3-31-23da}

\begin{tabular}{|c|c|c|c|c|c|c|}
\hline $\begin{array}{l}\text { June } \\
\text { July }\end{array}$ & $\begin{array}{l}19,1950 \\
14\end{array}$ & $\begin{array}{l}21.36 \\
21.63\end{array}$ & $\begin{array}{l}\text { Aug. 13, } 1950 \\
\text { Sept. } 22\end{array}$ & $\begin{array}{l}21.26 \\
21.69\end{array}$ & $\begin{array}{ll}\text { Oct. } & 20,1950 \\
\text { Dec. } & 7\end{array}$ & $\begin{array}{l}21.86 \\
21.97\end{array}$ \\
\hline
\end{tabular}

\section{3-31-30ad}

\begin{tabular}{|l|l|l|l|l|l|l|l|}
\hline June & 19,1950 & 30.46 & Aug. 12, 1950 & 30.24 & Oct. 20, 1950 & 30.26 \\
July 14 & 30.66 & Sept. 22 & 30.17 & Dec. 7 & 30.44 \\
\hline
\end{tabular}

3-31-30cc

\begin{tabular}{ll|l||l|l||l|l|l}
\hline June 19,1950 & 27.25 & Sept. 22, 1950 & 27.36 & Dec. 7, 1950 & 27.28 \\
July 14 & 27.51 & Oct. 20 & 27.49 & & \\
\hline
\end{tabular}

$3-32-2 b c$

\begin{tabular}{l|l|l|l|l||ll|l|}
\hline July 10,1950 & $\begin{array}{l}14.23 \\
\text { Aug. }\end{array}$ & $\begin{array}{l}\text { Sept. 19, 1950 } \\
\text { Oct. 18 }\end{array}$ & $\begin{array}{l}13.68 \\
13.59\end{array}$ & Dec. 6, 1950 & 13.73 \\
\hline
\end{tabular}

3-32-11bb

\begin{tabular}{|c|c|c|c|c|c|c|c|c|}
\hline $\begin{array}{l}\text { Feb. } \\
\text { Apr. } 1 \\
\text { June } \\
\text { Aug. } \\
\text { Oct. } \\
\text { Dec. } \\
\text { Feb. }\end{array}$ & $\begin{array}{cc}4, & 1948 \\
12 & \\
9 & \\
4 & \\
6 & \\
9 & \\
8, & 1949\end{array}$ & $\begin{array}{l}13.11 \\
13.42 \\
13.85 \\
14.05 \\
14.15 \\
13.40 \\
12.65\end{array}$ & $\begin{array}{l}\text { Apr. } \\
\text { June } \\
\text { Aug. } \\
\text { Oct. } \\
\text { Nov. } 1 \\
\text { Dec. } \\
\text { Jan. } 1\end{array}$ & $\begin{array}{rr}6, & 1949 \\
9 & \\
4 & \\
6 & \\
17 & \\
20 & \\
19, & 1950\end{array}$ & $\begin{array}{l}12.95 \\
12.83 \\
13.60 \\
14.01 \\
13.55 \\
13.50 \\
13.08\end{array}$ & $\begin{array}{l}\text { Apr. } 1 \\
\text { May } 2 \\
\text { July } 1 \\
\text { Aug. } \\
\text { Sept. } 1 \\
\text { Oct. } 1 \\
\text { Dec, }\end{array}$ & $\begin{array}{r}14,1950 \\
26 \\
10 \\
9 \\
19 \\
18 \\
6\end{array}$ & $\begin{array}{l}13.40 \\
13.68 \\
14.16 \\
13.90 \\
13.99 \\
13.19 \\
13.92\end{array}$ \\
\hline
\end{tabular}

\section{$3-32-12 c c$}

\begin{tabular}{l|l|l|l|l||l|l|l}
\hline Feb. 9, 1949 & 21.22 & June 9, 1949* & 21.12 & Oct. 18, 1950 & 21.79 \\
Apr. 6 & 21.39 & Aug. 26* & 21.80 & Dec. 6 & 21.66 \\
\hline
\end{tabular}

\section{3-32-13ba}

\begin{tabular}{|l|l||l|l||ll|l|}
\hline July 10,1950 & 9.34 & Sept. 19, 1950 & 8.53 & Dec. 6, 1950 & 8.90 \\
Aug. 9 & 9.10 & Oct. 18 & 9.07 & & \\
\hline
\end{tabular}


GROUND-WATER GEOLOGY, REPUBLICAN AND FRENCHMAN VALLEYS, NEBR. 677

Water-level measurements in wells, in feet below land-surface datum, with recorder chart teadings of lowest daily water levels in 1950 - Continued

\begin{tabular}{l|l||l|l||l|l}
\hline Date & $\begin{array}{l}\text { Water } \\
\text { level }\end{array}$ & Date & $\begin{array}{l}\text { Water } \\
\text { level }\end{array}$ & Date & $\begin{array}{l}\text { Water } \\
\text { level }\end{array}$ \\
\hline
\end{tabular}

HITCHCOCK COUNTY-Continued

$3-32-25 d b$

\begin{tabular}{|l|l||l|l||l|l|l|}
\hline June & 19,1950 & 15.03 & Aug. 12, 1950 & 14.77 & Oct. 20, 1950 & 15.09 \\
July 14 & 15.26 & Sept. 22 & 14.96 & Dec. 7 & 14.99 \\
\hline
\end{tabular}

$3-32-26 c d$

\begin{tabular}{|l|l||l|l||l|r|r}
\hline June 19,1950 & 5.75 & Aug. 12, 1950 & 5.10 & Oct. 20, 1950 & 5.55 \\
July 14 & 6.14 & Sept. 22 & 5.36 & Dec. 7 & 5.38 \\
\hline
\end{tabular}

3-32-26da

\begin{tabular}{|l|l||l|l||lr|r}
\hline June & 19,1950 & 4.85 & Aug. 12, 1950 & 4.11 & Oct. 20, 1950 & 4.72 \\
July 14 & 5.24 & Sept. 22 & 4.57 & Dec. 7 & 4.50 \\
\hline
\end{tabular}

\section{$3-32-26 \mathrm{db}$}

\begin{tabular}{l|l||l|l||l|r|r}
\hline Jume 19, 1950 & 5.44 & Aug. 12, 1950 & 4.74 & Oct. 20, 1950 & 5.29 \\
July 14 & 5.96 & Sept. 22 & 5.00 & Dec. 7 & 4.98 \\
\hline
\end{tabular}

3-32-26dd

\begin{tabular}{ll|r||l|l||lr|r}
\hline Feb. & 2,1948 & 28.30 & July 5,1949 & 27.95 & Apr. 26, 1950 & 28.05 \\
Apr. & 9 & 28.03 & Sept. 12* & 28.72 & June 2 & 28.10 \\
June & 7 & 28.05 & Oct. 3 & 28.88 & July 14 & 28.78 \\
Oct. & 4 & 29.32 & Nov. 15 & 28.55 & Aug. 12 & 27.73 \\
Dec. & 6 & 28.92 & Dec. 17 & 28.42 & Sept. 22 & 28.13 \\
Feb. & 7,1949 & 28.61 & Jan. 17, 1950 & 28.31 & Oct. 20 & 29.36 \\
June 8 & 28.08 & Feb. 23 & 28.14 & Dec. 7 & 28.14 \\
\hline
\end{tabular}

3-32-31aa

\begin{tabular}{|c|c|c|c|c|c|c|c|c|}
\hline $\begin{array}{l}\text { Feb. } \\
\text { Apr. } \\
\text { Jume } \\
\text { Aug. } \\
\text { Oct. } \\
\text { Dec. } \\
\text { Feb. } \\
\text { Apr. }\end{array}$ & $\begin{array}{cc}4, & 1948 \\
12 & \\
9 & \\
4 & \\
6 & \\
9 & \\
8, & 1949 \\
4 & \\
\end{array}$ & $\begin{array}{l}6.48 \\
6.19 \\
6.67 \\
6.84 \\
7.35 \\
6.63 \\
5.94 \\
5.32\end{array}$ & $\begin{array}{l}\text { June } \\
\text { July } \\
\text { Sept. } 1 \\
\text { Oct. } \\
\text { Nov. } 1 \\
\text { Dec. } 1 \\
\text { Jan. } 1 \\
\text { Feb. } 2\end{array}$ & $\begin{aligned} 8, & 1949 \\
19^{*} & \\
12 & \\
6 & \\
17 & \\
19 & \\
17, & 1950 \\
23 & \end{aligned}$ & $\begin{array}{l}5.42 \\
5.80 \\
6.50 \\
6.67 \\
6.43 \\
6.30 \\
7.05 \\
5.65\end{array}$ & $\begin{array}{l}\text { Apr. } \\
\text { June } \\
\text { July } \\
\text { Aug. } 1 \\
\text { Sept. } 1 \\
\text { Oct. } 1 \\
\text { Dec. }\end{array}$ & $\begin{aligned} 14, & 1950 \\
5 & \\
12 & \\
12 & \\
12 & \\
17 & \\
8 & \end{aligned}$ & $\begin{array}{l}5.83 \\
6.10 \\
6.57 \\
5.82 \\
6.35 \\
6.43 \\
6.26\end{array}$ \\
\hline
\end{tabular}

3-32-31dd

\begin{tabular}{ll|l||l|l||l|r|r}
\hline Jume 19,1950 & 14.90 & Aug. 12, 1950 & 14.45 & Oct. 20, 1950 & 14.77 \\
July 14 & 15.08 & Sept. 22 & 14.77 & Dec. 7 & 14.67 \\
\hline
\end{tabular}

3-32-32da

\begin{tabular}{|l|l||l|l|l|l|r|}
\hline June 19,1950 & 5.91 & Aug. 12, 1950 & 4.96 & Oct. 20, 1950 & 5.81 \\
July 14 & 6.06 & Sept. 22 & 5.63 & Dec. 7 & 5.74 \\
\hline
\end{tabular}

3-32-33cd

\begin{tabular}{ll|l||l|l|l|l|l|}
\hline Jume 19,1950 & 11.39 & Aug. 12, 1950 & 10.07 & Oct, 20, 1950 & 10.60 \\
July 14 & 11.36 & Sept. 22 & 10.39 & Dec. 7 & 10.84 \\
\hline
\end{tabular}


Water-level measurements in wells, in feet betow land-surface datum, with recorder chart readings of lowest deily water levels in 1950-Continued

\begin{tabular}{c|c|c|c||c|c}
\hline Date & $\begin{array}{l}\text { Water } \\
\text { level }\end{array}$ & Date & $\begin{array}{l}\text { Water } \\
\text { level }\end{array}$ & Date & $\begin{array}{l}\text { Water } \\
\text { level }\end{array}$ \\
\hline
\end{tabular}

HITCHCOCK COUNTY-Continued

3-32-33da

\begin{tabular}{|l|l||l|l||lr|r|}
\hline June 19, 1950 & 15.20 & Aug. 12, 1950 & 14.59 & Oct. 20, 1950 & 14.44 \\
July 14 & 15.28 & Sept. 22 & 14.35 & Dec. 7 & 14.53 \\
\hline
\end{tabular}

3-32-34bc

\begin{tabular}{|l|l||l|l|l|l|l|}
\hline June 19,1950 & 7.68 & Aug. 12, 1950 & 6.69 & Oct. 20, 1950 & 7.19 \\
July 14 & 8.17 & Sept. 22 & 7.08 & Dec. & 7 & 7.19 \\
\hline
\end{tabular}

$3-32-35$ ba

\begin{tabular}{|l|l||l|l||l|r|r}
\hline June 19,1950 & 20.52 & Aug. 12, 1950 & 20.06 & Oct. 20, 1950 & 20.35 \\
July 14 & 20.77 & Sept. 22 & 20.18 & Dec. 7 & 20.33 \\
\hline
\end{tabular}

$3-32-35 b b$

\begin{tabular}{|l|r|r|r||lr|r|r}
\hline June & 19,1950 & 8.63 & Aug. 12, 1950 & 7.89 & Oct. 20, 1950 & 8.45 \\
July 14 & 8.91 & Sept. 22 & 8.29 & Dec. 7 & 8.34 \\
\hline
\end{tabular}

$3-32-35 b c$

\begin{tabular}{|l|l|l|l|l|l|l|l|}
\hline June & 19,1950 & 8.94 & Aug. 12, 1950 & 8.43 & Oct. 20, 1950 & 8.83 \\
July & 14 & 9.28 & Sept. 22 & 8.81 & Dec. & 7 & 8.62 \\
\hline
\end{tabular}

3-33-35dc

\begin{tabular}{|c|c|c|c|c|c|}
\hline $\begin{array}{lrl}\text { Feb. } & 4, & 1948 \\
\text { Apr. } & 12 & \\
\text { June } & 9 & \\
\text { Aug. } & 4 & \\
\text { Oct. } & 6 & \\
\text { Dec. } & 9 & \\
\text { Feb. } & 8, & 1949 \\
\text { Apr. } & 4 & \end{array}$ & $\begin{array}{r}10.72 \\
10.29 \\
10.75 \\
11.38 \\
12.04 \\
11.32 \\
10.57 \\
9.95\end{array}$ & $\begin{array}{lrl}\text { June } & 10, & 1949 \\
\text { Aug. } & 3 & \\
\text { Oct. } & 6 & \\
\text { Nov. } & 17 & \\
\text { Dec. } & 19 & \\
\text { Jan. } & 17, & 1950 \\
\text { Feb. } & 23 & \end{array}$ & $\begin{array}{r}9.38 \\
10.57 \\
10.96 \\
10.64 \\
10.39 \\
10.19 \\
9.94\end{array}$ & 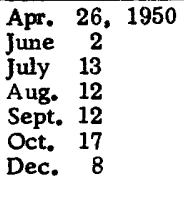 & $\begin{array}{r}9.82 \\
9.94 \\
9.99 \\
10.73 \\
10.95 \\
11.06 \\
11.32\end{array}$ \\
\hline
\end{tabular}

4-32-30dc

\begin{tabular}{|c|c|c|c|c|c|c|}
\hline $\begin{array}{l}\text { Apr. } \\
\text { Jume } \\
\text { Aug. } \\
\text { Oct. } \\
\text { Dec. } \\
\text { Feb. } \\
\text { Apr. } \\
\text { June }\end{array}$ & $\begin{array}{cc}12, & 1948 \\
9 & \\
4 & \\
6 & \\
9 & \\
8, & 1949 \\
6 & \\
9 & \end{array}$ & $\begin{array}{l}17.89 \\
18.47 \\
18.73 \\
18.95 \\
18.10 \\
17.36 \\
17.15 \\
17.58\end{array}$ & $\begin{array}{lcl}\text { July } & 19,1949^{*} \\
\text { Aug. } & 4 \\
\text { Aug. } & 26^{*} \\
\text { Oct. } 6 & \\
\text { Nov. } & 17 \\
\text { Dec. } & 20 \\
\text { Jan. } & 19, & 1950\end{array}$ & $\begin{array}{l}18.03 \\
18.35 \\
18.67 \\
18.70 \\
18.20 \\
18.04 \\
17.71\end{array}$ & 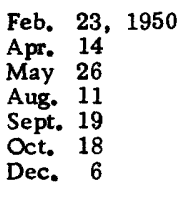 & $\begin{array}{l}17.49 \\
17.77 \\
18.20 \\
18.42 \\
18.64 \\
18.72 \\
18.52\end{array}$ \\
\hline
\end{tabular}

4-32-33db

\begin{tabular}{|c|c|c|c|c|c|c|}
\hline $\begin{array}{lrl}\text { Mar. } & 19, & 1946 \\
\text { May } & 29 & \\
\text { Apr. } & 6, & 1949 \\
\text { Jume } & 9^{\star} & \\
\text { Aug. } & 26^{\star} & \\
\text { Oct. } & 6 & \end{array}$ & $\begin{array}{l}34.54 \\
34.85 \\
34.18 \\
33.75 \\
35.52 \\
37.80\end{array}$ & $\begin{array}{lrl}\text { Nov. } & 17, & 1949 \\
\text { Dec. } 20 & \\
\text { Jan. } & 19,1950 \\
\text { Mar. } & 6 & \\
\text { Apr. } & 14 & \end{array}$ & $\begin{array}{l}\mathbf{3 4 . 3 0} \\
\mathbf{3 4 . 2 1} \\
33.94 \\
\mathbf{3 4 . 4 9} \\
\mathbf{3 4 . 5 8}\end{array}$ & $\begin{array}{l}\text { July } 1 \\
\text { Aug. } 1 \\
\text { Sept. } 1 \\
\text { Oct. } 18 \\
\text { Dec. }\end{array}$ & $\begin{array}{ll}10, & 1950 \\
11 & \\
19 & \\
18 & \\
6 & \end{array}$ & $\begin{array}{l}35.61 \\
35.25 \\
35.25 \\
35.25 \\
35.02\end{array}$ \\
\hline
\end{tabular}


GROUND-WATER GEOLOGY, REPUBLICAN AND FRENCHMAN VALLEYS, NEBR. 679

Water-level measurements in wells, in feet below land-surface datum, with recorder chart readings of lowest daily water levels in 1950-Continued

\begin{tabular}{c|l|l|l|l|l|l|l|l}
\hline Date & $\begin{array}{l}\text { Water } \\
\text { level }\end{array}$ & Date & $\begin{array}{l}\text { Water } \\
\text { level }\end{array}$ & Date & $\begin{array}{l}\text { Water } \\
\text { level }\end{array}$ \\
\hline
\end{tabular}

HITCHCOCK COUNTY-Continued

4-32-33dd

\begin{tabular}{ll|l|l|l|l|l|l|l|l|}
\hline July 10, 1950 & 9.73 & Sept. 19,1950 & 9.52 & Dec. & 6,1950 & 9.32 \\
Aug. 11 & 9.38 & Oct. 18 & & 9.55 & & \\
\hline
\end{tabular}

4-33-8bb

\begin{tabular}{|c|c|c|c|c|c|c|c|c|c|}
\hline $\begin{array}{l}\text { Feb. } \\
\text { Apr. } \\
\text { June } \\
\text { Aug. } \\
\text { Oct. } \\
\text { Dec. } \\
\text { Feb. } \\
\text { Apr. }\end{array}$ & $\begin{aligned} 4, & 1948 \\
12 & \\
9 & \\
4 & \\
6 & \\
9 & \\
8, & 1949 \\
6 & \end{aligned}$ & $\begin{array}{l}55.09 \\
54.94 \\
55.49 \\
55.73 \\
56.05 \\
55.42 \\
54.85 \\
54.51\end{array}$ & $\begin{array}{l}\text { June } \\
\text { July } \\
\text { Oct. } \\
\text { Nov. } \\
\text { Dec. } \\
\text { Jan. } \\
\text { Mar. }\end{array}$ & $\begin{array}{r}9 \\
19 \\
6 \\
17 \\
20 \\
19 \\
6\end{array}$ & $\begin{array}{r}1949 \\
1950\end{array}$ & $\begin{array}{l}54.43 \\
54.65 \\
55.64 \\
55.27 \\
55.02 \\
54.94 \\
54.75\end{array}$ & $\begin{array}{l}\text { Apr. } \\
\text { May } \\
\text { July } \\
\text { Aug. } \\
\text { Sept. } \\
\text { Oct. } \\
\text { Dec. }\end{array}$ & $\begin{array}{ll}14, & 1950 \\
26 & \\
11 & \\
11 & \\
19 & \\
16 & \\
6 & \end{array}$ & $\begin{array}{l}54.67 \\
55.10 \\
55.57 \\
55.56 \\
55.78 \\
55.71 \\
55.53\end{array}$ \\
\hline
\end{tabular}

4-33-9dd

\begin{tabular}{l|l||l|l||l|l|l|}
\hline July 11, 1950 & 23.98 & $\begin{array}{l}\text { Sept. } 19,1950 \\
\text { Oct. } 18\end{array}$ & $\begin{array}{l}23.42 \\
\text { Aug. 11 }\end{array}$ & $\mathbf{2 3 . 6 5}$ & Dec. 6,1950 & 23.47 \\
\hline
\end{tabular}

4-33-23ad

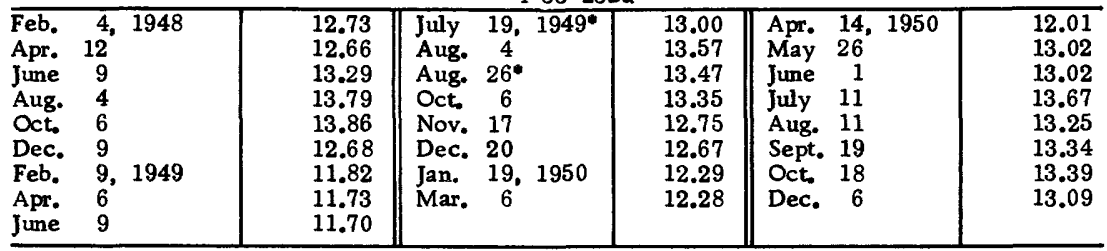

4-33-24cc

\begin{tabular}{|c|c|c|c|c|c|c|}
\hline Aug. & 11,1950 & 31.84 & Dec. $\quad 6,1950$ & 31.50 & & \\
\hline \multicolumn{7}{|c|}{$4-33-25 a a$} \\
\hline $\begin{array}{l}\text { July } \\
\text { Aug. }\end{array}$ & $\begin{array}{l}11,1950 \\
11\end{array}$ & $\begin{array}{l}8.87 \\
8.64\end{array}$ & $\begin{array}{l}\text { Sept. } 18,1950 \\
\text { Oct. } 18\end{array}$ & $\begin{array}{l}8.90 \\
8.62\end{array}$ & Dec. 6,1950 & 8.67 \\
\hline
\end{tabular}

RED WILLOW COUNTY

2-29-3bd

\begin{tabular}{|c|c|c|c|c|c|c|}
\hline $\begin{array}{l}\text { July } \\
\text { Aug. }\end{array}$ & $\begin{array}{ll}18, & 1950 \\
13 & \end{array}$ & $\begin{array}{l}32.70 \\
32.89\end{array}$ & Sept. 22, 1950 & 31.70 & Dec. 11,1950 & 32.81 \\
\hline \multicolumn{7}{|c|}{$2-29-4 a a$} \\
\hline $\begin{array}{l}\text { Feb. } \\
\text { Apr. } \\
\text { June } \\
\text { Aug. } \\
\text { Oct. } \\
\text { Dec. } \\
\text { Feb. } \\
\text { Apr. }\end{array}$ & $\begin{array}{rr}4, & 1948 \\
12 & \\
11 & \\
5 & \\
6 & \\
10 & \\
9, & 1949 \\
6 & \end{array}$ & $\begin{array}{r}10.39 \\
10.14 \\
10.93 \\
10.40 \\
11.52 \\
10.85 \\
10.59 \\
9.42\end{array}$ & $\begin{array}{lrl}\text { June } & 11, & 1949 \\
\text { Aug. } & 4 & \\
\text { Oct. } & 7 & \\
\text { Nov. } & 18 & \\
\text { Dec. } & 20 & \\
\text { Feb. } & 8, & 1950 \\
\text { Mar. } & 8 & \\
\text { May } & 2 & \end{array}$ & $\begin{array}{r}8.52 \\
10.42 \\
11.20 \\
10.74 \\
10.60 \\
10.37 \\
10.25 \\
10.22\end{array}$ & $\begin{array}{lll}\text { May } & 27, & 1950 \\
\text { June } & 29 & \\
\text { July } & 18 \\
\text { July } & 28 \\
\text { Aug. } & 13 \\
\text { Sept. } & 22 \\
\text { Oct. } & 20 \\
\text { Dec. } & 11\end{array}$ & $\begin{array}{r}10.08 \\
10.55 \\
6.25 \\
8.53 \\
9.12 \\
9.82 \\
10.14 \\
10.15\end{array}$ \\
\hline
\end{tabular}


Water-level measurements in wells, in feet below land-surface dafum, with recorder chart readings of lowest daily water levels in 1950-Continued

\begin{tabular}{c|c||l|l||l|l|}
\hline Date & $\begin{array}{l}\text { Water } \\
\text { level }\end{array}$ & Date & $\begin{array}{l}\text { Water } \\
\text { level }\end{array}$ & Date & $\begin{array}{l}\text { Water } \\
\text { level }\end{array}$ \\
\hline
\end{tabular}

RED WILIOW COUNTY-Continued

$2-29-4 a d$

\begin{tabular}{|c|c|c|c|c|c|c|c|}
\hline $\begin{array}{l}\text { Aug. } \\
\text { Aug. }\end{array}$ & $\begin{array}{l}13,1950 \\
19\end{array}$ & $\begin{array}{l}24.63 \\
24.54\end{array}$ & $\begin{array}{l}\text { Aug. 26, } 1950 \\
\text { Sept. } 2\end{array}$ & $\begin{array}{l}24.56 \\
24.84\end{array}$ & Sept. & 9,1950 & 24.73 \\
\hline
\end{tabular}

\begin{tabular}{|c|c|c|c|c|c|c|c|c|c|}
\hline Day & Sept. & Oct. & Nov. & Dec. & Day & Sept. & Oct. & Nov. & Dec. \\
\hline $\begin{array}{r}1 \\
2 \\
3 \\
4 \\
5 \\
6 \\
7 \\
8 \\
9 \\
10 \\
11 \\
12 \\
13 \\
14 \\
15 \\
16\end{array}$ & 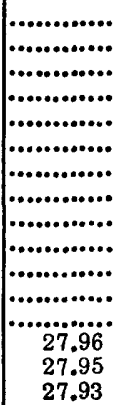 & $\begin{array}{c}\ldots \ldots \ldots \ldots \ldots \\
\ldots \ldots \ldots \ldots \ldots \\
\ldots \ldots \ldots \ldots \ldots \\
\ldots \ldots \ldots \ldots \ldots \\
\ldots \ldots \ldots \ldots \\
27.9 . \ldots \\
27.93 \\
27.94 \\
27.95 \\
27.97 \\
27.98 \\
27.99 \\
28.00 \\
28.01 \\
28.02\end{array}$ & $\begin{array}{l}28.15 \\
28.15 \\
28.16 \\
28.16 \\
28.16 \\
28.17 \\
28.18 \\
28.19 \\
28.20 \\
28.21 \\
28.21 \\
28.22 \\
28.23 \\
28.23 \\
28.24 \\
28.24\end{array}$ & $\begin{array}{l}28.33 \\
28.33 \\
28.33 \\
28.34 \\
28.34 \\
28.35 \\
28.35 \\
28.36 \\
28.36 \\
28.36 \\
28.36 \\
28.36 \\
28.36 \\
28.37 \\
28.37 \\
28.37\end{array}$ & $\begin{array}{l}17 \\
18 \\
19 \\
20 \\
21 \\
22 \\
23 \\
24 \\
25 \\
26 \\
27 \\
28 \\
29 \\
30 \\
31\end{array}$ & $\begin{array}{r}27.93 \\
27.92 \\
27.92 \\
27.92 \\
27.91 \\
27.90 \\
27.89 \\
27.89 \\
27.89 \\
27.89 \\
27.89 \\
27.90 \\
27.90 \\
27.90 \\
\ldots \ldots . . . .\end{array}$ & $\begin{array}{l}28.03 \\
28.04 \\
28.05 \\
28.06 \\
28.07 \\
28.08 \\
28.08 \\
28.09 \\
28.09 \\
28.10 \\
28.11 \\
28.11 \\
28.12 \\
28.13 \\
28.14\end{array}$ & $\begin{array}{l}28.25 \\
28.25 \\
28.26 \\
28.27 \\
28.27 \\
28.28 \\
28.29 \\
28.30 \\
28.30 \\
28.31 \\
28.31 \\
28.32 \\
28.32 \\
28.32 \\
\ldots \ldots . . . . .\end{array}$ & $\begin{array}{l}28.38 \\
28.38 \\
28.38 \\
28.38 \\
28.38 \\
28.40 \\
28.40 \\
28.40 \\
28.40 \\
28.41 \\
28.41 \\
28.41 \\
28.41 \\
28.41 \\
28.41\end{array}$ \\
\hline
\end{tabular}

\begin{tabular}{c|c||c|c||c|c}
\hline Date & $\begin{array}{l}\text { Water } \\
\text { level }\end{array}$ & Date & $\begin{array}{l}\text { Water } \\
\text { level }\end{array}$ & Date & $\begin{array}{l}\text { Water } \\
\text { level }\end{array}$ \\
\hline
\end{tabular}

$2-29-4 \mathrm{cba}$

\begin{tabular}{ll|l||l|l||ll|l}
\hline June 13,1950 & 14.65 & Aug. 13, 1950 & 12.73 & Oct. 20, 1950 & 14.03 \\
July 18 & 14.72 & Sept. 22 & 13.70 & Dec. 11 & 14.47 \\
\hline
\end{tabular}

$2-29-4 c b c$

\begin{tabular}{l|l||l|l||l|l|}
\hline July 18, 1950 & 21.56 & Sept. 22, 1950 & 19.09 & Dec. 11, 1950 & 20.23 \\
Aug. 13 & 20.75 & Oct. 20 & 19.71 & & \\
\hline
\end{tabular}

$2-29-4 d a$

\begin{tabular}{|c|c|c|c|c|c|c|}
\hline July 1 & 18,1950 & 26.80 & Aug. 13, 1950 & 25.07 & & \\
\hline \multicolumn{7}{|c|}{$2-29-4 d d$} \\
\hline $\begin{array}{ll}\text { July } & 1 \\
\text { Aug. } & 1\end{array}$ & $\begin{array}{l}18,1950 \\
13\end{array}$ & $\begin{array}{l}25.18 \\
24.62\end{array}$ & $\begin{array}{l}\text { Sept. } 22,1950 \\
\text { Oct. } 20\end{array}$ & $\begin{array}{l}24.20 \\
24.27\end{array}$ & Dec. 11,1950 & 24.48 \\
\hline
\end{tabular}

2-29-5ab

\begin{tabular}{|c|c|c|c|c|c|c|c|c|}
\hline $\begin{array}{l}\text { Feb. } \\
\text { Apr. } 1 \\
\text { June } \\
\text { Oct. } \\
\text { Dec. } 1 \\
\text { Feb. } \\
\text { Apr. }\end{array}$ & $\begin{array}{rr}4, & 1948 \\
12 & \\
11 & \\
6 & \\
10 & \\
9, & 1949 \\
7 & \end{array}$ & $\begin{array}{l}18.35 \\
18.31 \\
19.80 \\
19.92 \\
19.21 \\
18.89 \\
18.42\end{array}$ & $\begin{array}{l}\text { Jume } 1 \\
\text { Aug. } \\
\text { Oct. } \\
\text { Nov. } 1 \\
\text { Dec. } 2 \\
\text { Feb. } \\
\text { Mar. }\end{array}$ & $\begin{aligned} 11, & 1949 \\
4 & \\
6 & \\
18 & \\
20 & \\
8, & 1950 \\
8 & \end{aligned}$ & $\begin{array}{l}17.70 \\
19.88 \\
19.42 \\
19.13 \\
19.05 \\
18.80 \\
18.99\end{array}$ & $\begin{array}{l}\text { May } \\
\text { June } \\
\text { July } \\
\text { Aug. } \\
\text { Sept. } \\
\text { Oct. } \\
\text { Dec. }\end{array}$ & $\begin{array}{rr}2, & 1950 \\
8 & \\
18 & \\
13 & \\
22 & \\
20 & \\
11 & \end{array}$ & $\begin{array}{l}19.44 \\
18.86 \\
19.17 \\
18.19 \\
18.20 \\
18.76 \\
18.90\end{array}$ \\
\hline
\end{tabular}


GROUND-WATER GEOLOGY, REPUBLICAN AND FRENCHMAN VALLEYS, NEBR. 681

Water-level measurements in wells, in feet below land-surface datum, with recorder chart readings of lowest daily water levels in 1950-Continued

\begin{tabular}{c|c||l|l||l|l|l}
\hline Date & $\begin{array}{l}\text { Water } \\
\text { level }\end{array}$ & Date & $\begin{array}{l}\text { Water } \\
\text { level }\end{array}$ & Date & $\begin{array}{l}\text { Water } \\
\text { level }\end{array}$ \\
\hline
\end{tabular}

RED WILLOW COUNTY-Continued

$2-29-5 c a$

\begin{tabular}{|c|c|c|c|c|c|}
\hline $\begin{array}{ll}\text { June } & 13,1950 \\
\text { July } & 18\end{array}$ & $\begin{array}{l}21.71 \\
22.60\end{array}$ & $\begin{array}{l}\text { Aug. } 13,1950 \\
\text { Sept. } 22\end{array}$ & $\begin{array}{l}21.40 \\
21.08\end{array}$ & $\begin{array}{ll}\text { Oct, } & 20,1950 \\
\text { Dec. } & 11\end{array}$ & $\begin{array}{l}21.34 \\
21.55\end{array}$ \\
\hline
\end{tabular}

2-29-6bc

\begin{tabular}{lr|r||l|l||l|l}
\hline June & 5,1950 & 16.14 & Sept. 16, 1950 & 15.09 & Nov. 11, 1950 & 16.00 \\
July 14 & 16.41 & Sept. 22 & 15.27 & Nov. 18 & 15.98 \\
Aug. & 5 & 15.68 & Sept. 30 & 15.43 & Nov. 24 & 16.04 \\
Aug. 13 & 13.07 & Oct. 7 & 15.53 & Dec. 2 & 16.09 \\
Aug. 19 & 13.75 & Oct. 13 & 15.63 & Dec. 7 & 16.08 \\
Aug. 26 & 14.26 & Oct. 20 & 15.69 & Dec. 16 & 16.08 \\
Sept. 2 & 14.63 & Oct. 28 & 15.84 & Dec. 22 & 16.12 \\
Sept. 9 & 14.89 & Nov. 4 & 15.91 & & \\
\hline
\end{tabular}

2-29-9bb

\begin{tabular}{l|l|l|l|l|l|l|}
\hline July 18, 1950 & 28.43 & Sept. 22, 1950 & 27.32 & Oct. 20, 1950 & 27.40 \\
Aug. 13 & 27.65 & & & & \\
\hline
\end{tabular}

2-30-1aa

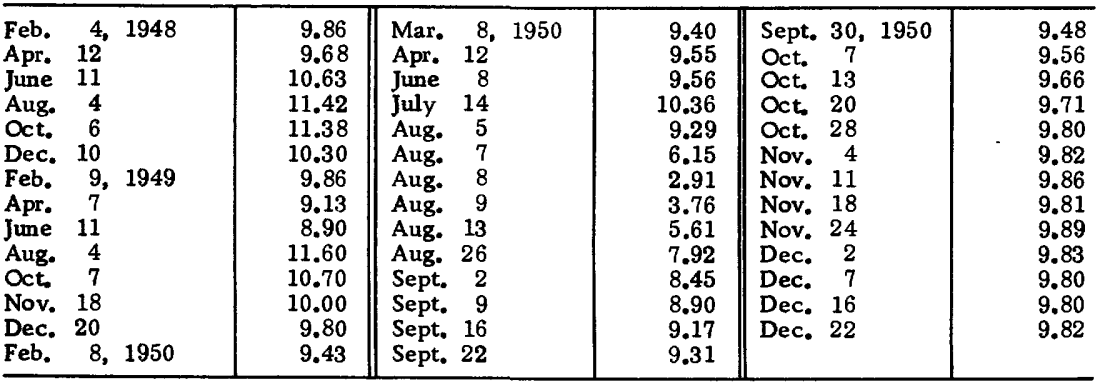

$2-30-6 d d$

\begin{tabular}{l|l||l|l||l|l|l}
\hline Aug. 4, 1950 & 107.51 & Oct. 20, 1950 & 107.43 & Dec. 7, 1950 & 107.47 \\
Sept. 22 & 107.48 & & & & \\
\hline
\end{tabular}

$2-30-12 a a$

\begin{tabular}{l|l||l|l||l|r|r}
\hline Sept. 22, 1950 & 22.54 & Oct. 28, 1950 & 22.63 & Dec. 2, 1950 & 22.89 \\
Sept. 30 & 22.53 & Nov. 4 & 22.67 & Dec. 7 & 22.47 \\
Oct. 7 & 22.53 & Nov. 11 & 22.73 & Dec. 16 & 23.03 \\
Oct. 13 & 22.56 & Nov. 18 & 22.77 & Dec. 22 & 23.08 \\
Oct. 20 & 22.57 & Nov. 24 & 22.87 & & & \\
\hline
\end{tabular}

2-30-12ad

\begin{tabular}{|c|c|c|c|c|c|c|c|c|}
\hline $\begin{array}{l}\text { Feb. } \\
\text { Apr. } 1 \\
\text { Jume } 1 \\
\text { Aug. } \\
\text { Oct. }\end{array}$ & $\begin{array}{rr}4, & 1948 \\
12 & \\
11 & \\
5 & \\
6 & \end{array}$ & $\begin{array}{l}28.91 \\
29.47 \\
29.62 \\
29.34 \\
27.76\end{array}$ & $\begin{array}{l}\text { Dec. } \\
\text { Feb. } \\
\text { Apr. } \\
\text { June } 1 \\
\text { Aug. }\end{array}$ & $\begin{array}{rr}10, & 1948 \\
9, & 1949 \\
7 & \\
11 & \\
4 & \end{array}$ & $\begin{array}{l}29.12 \\
29.60 \\
29.89 \\
29.31 \\
30.15\end{array}$ & $\begin{array}{l}\text { Oct. } \\
\text { Nov. } 1 \\
\text { Dec. } 2 \\
\text { Feb. } \\
\text { Mar. }\end{array}$ & $\begin{array}{rr}7, & 1949 \\
18 & \\
20 & \\
8, & 1950 \\
8 & \end{array}$ & $\begin{array}{l}29.32 \\
29.25 \\
29.34 \\
29.64 \\
29,91\end{array}$ \\
\hline
\end{tabular}


Water-level measurements in wells, in feet below land-surface datum, with recorder chart readings of lowest daily water levels in 1950 - Continued

\begin{tabular}{c|c||c|c||c|c}
\hline Date & $\begin{array}{l}\text { Water } \\
\text { level }\end{array}$ & Date & $\begin{array}{l}\text { Water } \\
\text { level }\end{array}$ & Date & $\begin{array}{l}\text { Water } \\
\text { level }\end{array}$ \\
\hline
\end{tabular}

RED WILLOW COUNTY-Continued

2-30-12ad-Continued

\begin{tabular}{|c|c|c|c|c|c|c|}
\hline $\begin{array}{l}\text { Apr. } \\
\text { Jume } \\
\text { July } \\
\text { Aug. } \\
\text { Aug. } \\
\text { Aug. } \\
\text { Aug. }\end{array}$ & $\begin{aligned} 12, & 1950 \\
8 & \\
14 & \\
5 & \\
13 & \\
19 & \\
26 & \end{aligned}$ & $\begin{array}{l}30.15 \\
30.21 \\
29.50 \\
29.45 \\
28.94 \\
28.89 \\
28.81\end{array}$ & $\begin{array}{lr}\text { Sept. } 2,1950 \\
\text { Sept. } 9 \\
\text { Sept. } 16 \\
\text { Sept. } 22 \\
\text { Sept. } 30 \\
\text { Oct. } \quad 7 \\
\text { Oct. } 13\end{array}$ & $\begin{array}{l}28.78 \\
28.70 \\
28.67 \\
28.65 \\
28.63 \\
28.34 \\
28.31\end{array}$ & $\begin{array}{lr}\text { Oct. } & 20,1950 \\
\text { Nov. } & 11 \\
\text { Nov. } & 18 \\
\text { Nov. } & 24 \\
\text { Dec. } & 7 \\
\text { Dec. } & 16 \\
\text { Dec. } & 22\end{array}$ & $\begin{array}{l}28.30 \\
28.72 \\
28.73 \\
28.84 \\
28.60 \\
28.71 \\
28.73\end{array}$ \\
\hline
\end{tabular}

2-30-12cb

\begin{tabular}{|c|c|c|c|c|c|c|}
\hline Aug. & 3,1950 & 31.92 & Sept. 22, 1950 & 28.93 & Oct, 20,1950 & 29.44 \\
\hline \multicolumn{7}{|c|}{$2-30-12 d d$} \\
\hline $\begin{array}{l}\text { July } 1 \\
\text { Aug. } \\
\text { Aug. } 1 \\
\text { Aug. } \\
\text { Aug. } \\
\text { Sept. } \\
\text { Sept. } \\
\text { Sept. }\end{array}$ & $\begin{aligned} 14, & 1950 \\
5 & \\
13 & \\
19 & \\
26 & \\
2 & \\
9 & \\
16 & \end{aligned}$ & $\begin{array}{l}21.54 \\
20.95 \\
19.96 \\
19.78 \\
19.81 \\
19.59 \\
19.43 \\
19.35\end{array}$ & $\begin{array}{lr}\text { Sept. } & 22,1950 \\
\text { Sept. } & 30 \\
\text { Oct. } & 7 \\
\text { Oct. } & 13 \\
\text { Oct. } & 20 \\
\text { Oct. } & 28 \\
\text { Nov. } & 4\end{array}$ & $\begin{array}{l}19.40 \\
19.38 \\
19.34 \\
19.38 \\
19.42 \\
19.42 \\
19.47\end{array}$ & 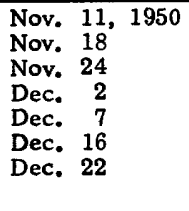 & $\begin{array}{l}19.49 \\
19.53 \\
19.60 \\
19.64 \\
19.67 \\
19.74 \\
19.80\end{array}$ \\
\hline
\end{tabular}

$2-30-24 b a$

\begin{tabular}{ll|l|l|l|l|l|l|}
\hline Aug. 4, 1950 & 108.75 & Sept. 22, 1950 & 108.81 & Oct. 20, 1950 & 108.53 \\
\hline
\end{tabular}

\section{3-26-1ac}

\begin{tabular}{|l|l||l|l||l|l|l|}
\hline Jume & 9,1950 & 7.44 & Sept. 19,1950 & 7.80 & Dec. 5, 1950 & \\
July 18 & 7.61 & Oct. 18 & 7.96 & & \\
\hline
\end{tabular}

$3-26-1 \mathrm{cc}$

\begin{tabular}{|c|c|c|c|c|c|c|}
\hline May & 23,1950 & 39.50 & June 9,1950 & 39.23 & & \\
\hline \multicolumn{7}{|c|}{$3-26-3 a b$} \\
\hline $\begin{array}{l}\text { Jume } \\
\text { July }\end{array}$ & $\begin{array}{l}14,1950 \\
19\end{array}$ & $\begin{array}{l}3.73 \\
3.38\end{array}$ & $\begin{array}{l}\text { Aug. } 15,1950 \\
\text { Sept. } 17\end{array}$ & $\begin{array}{l}2.95 \\
3.44\end{array}$ & $\begin{array}{l}\text { Oct. } 17,1950 \\
\text { Dec. } 6\end{array}$ & $\begin{array}{l}3.79 \\
3.62\end{array}$ \\
\hline
\end{tabular}

3-26-3bb

\begin{tabular}{|l|l||l|l||ll|l|}
\hline June 14,1950 & 6.35 & Aug. 15, 1950 & 5.99 & Dec. 6, 1950 & & 6.95 \\
July 19 & 6.21 & Oct. 17 & 7.07 & & \\
\hline
\end{tabular}

3-26-3dd

\begin{tabular}{|l|l||l|l||l|l|l}
\hline June & 9,1950 & 6.32 & Aug. 15, 1950 & 5.47 & Oct. 18, 1950 & 6.66 \\
July 18 & 6.28 & Sept. 19 & 6.38 & Dec. 5 & 6.67 \\
\hline
\end{tabular}


GROUND-WATER GEOLOGY, REPUBLICAN AND FRENCHMAN VALLEYS, NEBR. 683

Water-level measurements in wells, in feet below landasurface datum, with recorder cahrt readings of lowest daily water levels in 1950-Continued

\begin{tabular}{c|c||l|l||l|l|l}
\hline Date & $\begin{array}{l}\text { Water } \\
\text { level }\end{array}$ & Date & $\begin{array}{l}\text { Water } \\
\text { level }\end{array}$ & $\begin{array}{l}\text { Water } \\
\text { level }\end{array}$ \\
\hline
\end{tabular}

RED WILLOW COUNTY-Continued

$3-26-5 b b$

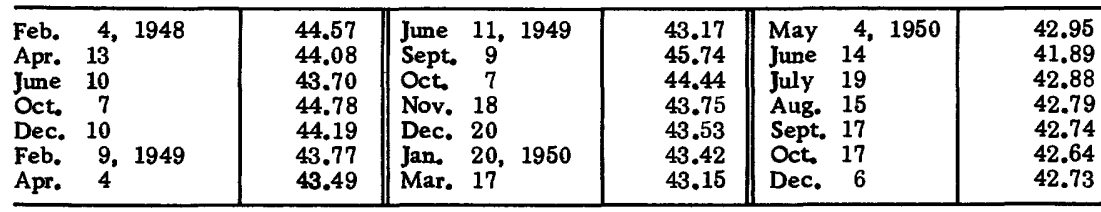

$3-26-5 c b$

\begin{tabular}{lr|r||lr|r||lr|r}
\hline Apr. & 13,1948 & 16.35 & June & 11,1949 & 15.57 & May 4,1950 & 16.08 \\
June & 10 & 16.72 & Aug. & 4 & & 16.22 & June 14 & 15.68 \\
Aug. & 5 & 16.38 & Oct. 7 & 16.80 & July 19 & 16.08 \\
Oct. & 7 & 17.35 & Nov. 18 & 16.60 & Aug. 15 & 15.60 \\
Dec. 10 & 16.96 & Dec. 20 & & 16.42 & Sept. 17 & 15.94 \\
Feb. 9,1949 & 16.59 & Jan. 20,1950 & 16.24 & Oct. 17 & 16.11 \\
Apr. 4 & 15.75 & Mar. 17 & 15.97 & Dec. 6 & 16.17 \\
\hline
\end{tabular}

$3-26-5 c c$

\begin{tabular}{|l|l||l|l||lr|r}
\hline June 14,1950 & 9.91 & Aug. 15, 1950 & 9.31 & Oct. 17, 1950 & 9.92 \\
July 19 & 9.97 & Sept. 17 & 9.77 & Dec. 6 & 10.87 \\
\hline
\end{tabular}

$3-26-5 \mathrm{db}$

\begin{tabular}{|l|l|l|l|l||l|l|}
\hline June 14,1950 & 3.24 & Sept. 17, 1950 & 2.72 & Dec. 6, 1950 & 3.12 \\
July 19 & 2.74 & Oct. 17 & 3.14 & & \\
\hline
\end{tabular}

$3-26-6 c c$

\begin{tabular}{|l|l||l|l||lr|r|r}
\hline June 14,1950 & 12.32 & Aug. 15, 1950 & 11.46 & Oct. & 17,1950 & 12.23 \\
July 19 & 12.42 & Sept. 17 & 11.92 & Dec. & 6 & 12.35 \\
\hline
\end{tabular}

$3-26-7 b c$

\begin{tabular}{|l|l||l|l||lr|r|r}
\hline Jume 14, 1950 & 6.33 & Aug. 15, 1950 & 5.22 & Oct. 17, 1950 & 6.50 \\
July 19 & 6.47 & Sept. 17 & 6.25 & Dec. 6 & 7.52 \\
\hline
\end{tabular}

$3-26-8 c c$

\begin{tabular}{|l|l||l|l||lc|r}
\hline June & 9,1950 & 11.45 & Aug. 15, 1950 & 11.21 & Oct. 18, 1950 & 11.89 \\
July 18 & 11.75 & Sept. 19 & 11.71 & Dec. 5 & 11.73 \\
\hline
\end{tabular}

3-26-9aa

\begin{tabular}{|c|c||l|l||l|l|l}
\hline June & 9,1950 & 7.41 & Aug. 15, 1950 & 5.72 & Oct. 18, 1950 & 7.43 \\
July 18 & 6.94 & Sept. 19 & 6.99 & Dec. 5 & 7.69 \\
\hline
\end{tabular}

3-26-9ad

\begin{tabular}{l|l|l||l|l||lc|r}
\hline June & 9,1950 & 9.48 & Aug. 15, 1950 & 6.75 & Oct. 18, 1950 & 8.70 \\
July 18 & 8.36 & Sept. 19 & & 8.06 & Dec. 5 & 9.21 \\
\hline
\end{tabular}


Water-level measurements in wells, in feet below land-surface datum, with recorder chart readings of lowest daily water levels in 1950-Continued

\begin{tabular}{c|c||c|c|c|c}
\hline Date & $\begin{array}{l}\text { Water } \\
\text { level }\end{array}$ & Date & $\begin{array}{l}\text { Water } \\
\text { level }\end{array}$ & Date & $\begin{array}{l}\text { Water } \\
\text { level }\end{array}$ \\
\hline
\end{tabular}

RED WILLOW COUNTY-Continued

3-26-9bd

\begin{tabular}{|c|c|c|c|c|c|}
\hline $\begin{array}{l}\text { June } \\
\text { July } \\
18\end{array}$ & $\begin{array}{l}11.34 \\
10.84\end{array}$ & $\begin{array}{l}\text { Aug. } 15,1950 \\
\text { Sept. } 19\end{array}$ & $\begin{array}{r}9.98 \\
10.53\end{array}$ & $\begin{array}{l}\text { Oct. } 18,1950 \\
\text { Dec. } 5\end{array}$ & $\begin{array}{l}10.95 \\
11.40\end{array}$ \\
\hline
\end{tabular}

$3-26-9 \mathrm{cb}$

\begin{tabular}{ll|r||lr|r||lr|r}
\hline Feb. & 2,1948 & 16.69 & June 6,1949 & 15.60 & May & 2,1950 & 15.99 \\
Apr. & 9 & 16.51 & Aug. 1 & 15.55 & June 9 & & 16.07 \\
June & 7 & 16.90 & Oct. 3 & 16.10 & July 18 & 15.58 \\
Aug. & 2 & 16.04 & Nov. 15 & 16.19 & Aug. 15 & 15.10 \\
Oct. & 1 & 16.75 & Dec. 17 & 16.17 & Sept. 19 & 15.38 \\
Dec. & 6 & 16.82 & Jan. 19, 1950 & 16.25 & Oct. 18 & 15.79 \\
Feb. & 7,1949 & 16.72 & Mar. 16 & 16.05 & Dec. 5 & 15.98 \\
Apr. & 7 & 16.12 & & & & & \\
\hline
\end{tabular}

3-26-11ab

\begin{tabular}{|c|c|c|c|c|c|}
\hline Sept. 19,1950 & 39.30 & Oct. 18,1950 & 39.15 & Dec. 5,1950 & 39.14 \\
\hline \multicolumn{6}{|c|}{$3-26-11 a c$} \\
\hline $\begin{array}{lrl}\text { June } & 9,1950 \\
\text { July } & 18 & \end{array}$ & $\begin{array}{l}49.38 \\
49.29\end{array}$ & $\begin{array}{l}\text { Sept. } 19,1950 \\
\text { Oct. } 18\end{array}$ & $\begin{array}{l}49.82 \\
49.44\end{array}$ & Dec, 5, 1950 & 49.34 \\
\hline
\end{tabular}

3-26-11bb

\begin{tabular}{ll|r||lr|r||lr|r}
\hline Feb. & 2,1948 & 8.85 & June & 6,1949 & 7.85 & May 2,1950 & 8.29 \\
Apr. & 9 & 8.52 & Aug. 1 & 8.35 & June 9 & \\
June & 7 & 8.77 & Sept. 9 & 8.86 & July 18 & 7.63 \\
Aug. & 2 & 8.05 & Oct. 7 & 9.04 & Aug. 15 & 6.40 \\
Oct. & 4 & 9.43 & Nov. 15 & 8.82 & Sept. 19 & 7.85 \\
Dec. & 6 & 9.27 & Dec. 17 & 8.71 & Oct. 18 & 8.28 \\
Feb. & 7,1949 & 8.81 & Jan. 19, 1950 & 8.54 & Dec. 5 & 8.47 \\
Apr. & 7 & 8.21 & Mar. 16 & 8.16 & & \\
\hline
\end{tabular}

\begin{tabular}{|c|c|c|c|c|c|c|}
\hline \multicolumn{7}{|c|}{$3-26-12 \mathrm{aa}$} \\
\hline $\begin{array}{l}\text { May } \\
\text { June } \\
\text { July }\end{array}$ & $\begin{array}{c}18,1950 \\
9 \\
18\end{array}$ & $\begin{array}{l}45.68 \\
45.65 \\
45.57\end{array}$ & $\begin{array}{l}\text { Aug. } 15,1950 \\
\text { Sept. } 19\end{array}$ & $\begin{array}{l}45.62 \\
45.53\end{array}$ & $\begin{array}{l}\text { Oct. } 18,1950 \\
\text { Dec. } 5\end{array}$ & $\begin{array}{l}45.58 \\
45.72\end{array}$ \\
\hline
\end{tabular}

\section{3-26-18bb}

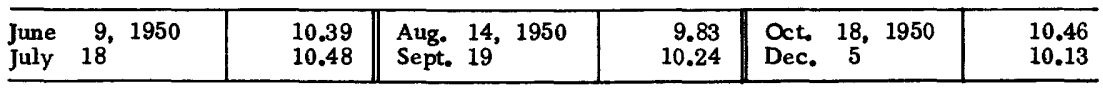

$3-27-2 c c$

\begin{tabular}{|c|c||l|l||lr|r}
\hline June & 8,1950 & 3.61 & Aug. 15, 1950 & 2.62 & Oct. 17, 1950 & 4.12 \\
July 19 & 4.56 & Sept. 17 & 3.47 & Dec. 6 & 3.86 \\
\hline
\end{tabular}

3-27-2da

\begin{tabular}{|l|l||l|l||lr|r|}
\hline June & 14,1950 & 17.59 & Aug. 5, 1950 & 17.32 & Oct. 17, 1950 & 17.26 \\
July 19 & 17.63 & Sept. 17 & 17.10 & Dec. 6 & 17.33 \\
\hline
\end{tabular}


GROUND-WATER GEOLOGY, REPUBLICAN AND FRENCHMAN VALLEYS, NEBR. 685

Water-level measurements in wells, in feet below land-surface datum, with recorder chart readings of lowest daily water levels in 1950-Continued

\begin{tabular}{c|l||l|l||l|l|l|l|l|l}
\hline Date & $\begin{array}{l}\text { Water } \\
\text { level }\end{array}$ & Date & $\begin{array}{l}\text { Water } \\
\text { level }\end{array}$ & level \\
\hline
\end{tabular}

RED WILLOW COUNTY-Continued

$3-27-7 \mathrm{~cd}$

\begin{tabular}{lr|r||l|l||l|r}
\hline Jume & 8,1950 & 13.68 & Sept. 16, 1950 & 14.30 & Nov. 11, 1950 & 14.57 \\
July 19 & 14.61 & Sept. 17 & 14.28 & Nov. 18 & 14.44 \\
Aug. & 5 & 13.97 & Sept. 23 & 14.45 & Nov. 24 & 14.50 \\
Aug. 13 & 13.64 & Sept. 30 & 14.56 & Dec. 2 & 14.45 \\
Aug. 15 & 13.64 & Oct. 7 & 14.65 & Dec. 5 & 14.48 \\
Aug. 19 & 13.78 & Oct. 13 & 14.68 & Dec. 9 & 14.44 \\
Aug. 26 & 13.98 & Oct. 17 & 14.64 & Dec. 16 & 14.35 \\
Sept. 2 & 14.07 & Oct. 28 & 14.66 & Dec. 22 & 14.29 \\
Sept. 9 & 14.25 & Nov. 4 & 14.56 & & \\
\hline
\end{tabular}

$3-27-7 \mathrm{db}$

\begin{tabular}{|l|l||l|l||l|l|l|}
\hline June & 8,1950 & 8.88 & Aug. 17, 1950 & 8.28 & Oct. 17, 1950 & 9.42 \\
July 19 & 9.62 & Sept. 17 & 8.89 & Dec. 5 & 9.40 \\
\hline
\end{tabular}

$3-27-7 \mathrm{dc}$

\begin{tabular}{|c|c|c|c|c|c|c|c|c|}
\hline $\begin{array}{l}\text { Feb. } \\
\text { Apr. } \\
\text { June } \\
\text { Aug. } \\
\text { Oct. } \\
\text { Dec. } \\
\text { Feb. } \\
\text { Apr. }\end{array}$ & $\begin{aligned} 4, & 1948 \\
12 & \\
10 & \\
5 & \\
8 & \\
10 & \\
8, & 1949 \\
4 & \end{aligned}$ & $\begin{array}{l}9.72 \\
9.32 \\
9.85 \\
8.04 \\
9.25 \\
9.52 \\
9.27 \\
8.40\end{array}$ & $\begin{array}{lr}\text { June } & 11, \\
\text { Aug. } & 4 \\
\text { Sept. } & 9 \\
\text { Oct. } & 7 \\
\text { Nov. } & 18 \\
\text { Dec. } & 20 \\
\text { Jan. } & 20, \\
\text { Mar. } & 17\end{array}$ & $\begin{array}{r}1949 \\
1950\end{array}$ & $\begin{array}{l}6.95 \\
8.32 \\
9.10 \\
9.48 \\
9.44 \\
9.25 \\
9.06 \\
8.45\end{array}$ & $\begin{array}{l}\text { May } \\
\text { June } \\
\text { July } \\
\text { Aug. } \\
\text { Sept. } \\
\text { Oct. } \\
\text { Dec. }\end{array}$ & $\begin{aligned} 4, & 1950 \\
8 & \\
19 & \\
15 & \\
17 & \\
17 & \\
5 & \end{aligned}$ & $\begin{array}{l}8.54 \\
8.12 \\
8.75 \\
7.37 \\
8.18 \\
8.68 \\
8.89\end{array}$ \\
\hline
\end{tabular}

$$
\text { 3-27-7dd }
$$

\begin{tabular}{|c|c|c|c|c|c|}
\hline $\begin{array}{l}\text { June } \\
\text { July } \\
19\end{array}$ & $\begin{array}{l}11.26 \\
11.99\end{array}$ & $\begin{array}{l}\text { Aug. } 17,1950 \\
\text { Sept. } 17\end{array}$ & $\begin{array}{l}10.98 \\
11.56\end{array}$ & $\begin{array}{l}\text { Oct. } 17,1950 \\
\text { Dec. } 5\end{array}$ & $\begin{array}{l}11.85 \\
11.88\end{array}$ \\
\hline
\end{tabular}

3-27-8ac

\begin{tabular}{lr|r||lr|r||lr|r}
\hline Feb. & 4,1948 & 11.60 & Dec. 10, 1948 & 11.74 & Oct. 7, 1949 & 11.34 \\
Apr. 12 & 11.54 & Feb. 8,1949 & 11.53 & Nov. 18 & 11.27 \\
June & 10 & 11.90 & Apr. 4 & 11.09 & Dec. 20 & 11.02 \\
Aug. & 5 & 10.90 & June 11 & 10.12 & Jan. 20, 1950 & 11.58 \\
Oct. 7 & 11.49 & Aug. 4 & 10.94 & & & \\
\hline
\end{tabular}

3-28-8db

\begin{tabular}{|c|c||c|c||l|l|r|}
\hline June & 8,1950 & 10.80 & Aug. 17, 1950 & 10.00 & Oct. 17, 1950 & 10.85 \\
July 19 & 11.10 & Sept. 17 & 10.51 & Dec. 5 & 11.09 \\
\hline
\end{tabular}

3-27-8dc

\begin{tabular}{|c|c|c|c|c|c|c|}
\hline Jun & 8,1950 & 10.02 & July 19,1950 & 11.03 & Aug. 15,1950 & 9.82 \\
\hline \multicolumn{7}{|c|}{$3-27-9$ ad } \\
\hline Jun $_{\text {Jul }}$ & $\begin{array}{r}8,1950 \\
19\end{array}$ & $\begin{array}{l}10.15 \\
10.62\end{array}$ & $\begin{array}{l}\text { Aug. } 15,1950 \\
\text { Sept. } 17\end{array}$ & $\begin{array}{l}9.00 \\
9.69\end{array}$ & $\begin{array}{l}\text { Oct. } 17,1950 \\
\text { Dec. } 5\end{array}$ & $\begin{array}{l}10.22 \\
10.55\end{array}$ \\
\hline
\end{tabular}


Water-level measurements in wells, in feet below land-surface datum, with recorder chart readings of lowest daily water levels in 1950-Continued

\begin{tabular}{|c|c|c|c|c|c|}
\hline Date & $\begin{array}{l}\text { Water } \\
\text { level }\end{array}$ & Date & $\begin{array}{l}\text { Water } \\
\text { level }\end{array}$ & Date & $\begin{array}{l}\text { Water } \\
\text { level }\end{array}$ \\
\hline
\end{tabular}

RED WILLOW COUNTY-Continued

\begin{tabular}{|c|c|c|c|c|c|c|c|c|}
\hline \multicolumn{9}{|c|}{$3-27-10 a a$} \\
\hline $\begin{array}{l}\text { June } \\
\text { Sept. } 1\end{array}$ & $\begin{array}{l}8,1950 \\
17\end{array}$ & $\begin{array}{l}4.75 \\
4.48\end{array}$ & Oct. & 17,1950 & 5.26 & Dec. & 6,1950 & 5.40 \\
\hline
\end{tabular}

$3-27-10 \mathrm{cb}$

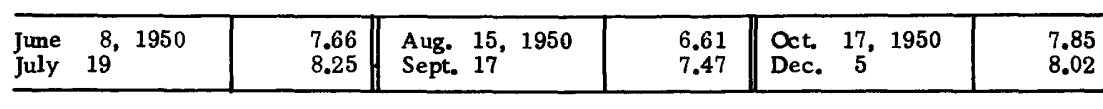

3-27-11 aa2

\begin{tabular}{|c|c|c|c|c|c|c|}
\hline Jume & $\begin{array}{l}14,1950 \\
19\end{array}$ & $\begin{array}{l}5.55 \\
5.92\end{array}$ & $\begin{array}{l}\text { Aug. } 15,1950 \\
\text { Sept. } 17\end{array}$ & $\begin{array}{l}3.46 \\
4.63\end{array}$ & $\begin{array}{l}\text { Oct. } 17,1950 \\
\text { Dec. } 6\end{array}$ & $\begin{array}{l}5.19 \\
5.55\end{array}$ \\
\hline \multicolumn{7}{|c|}{$3-27-11 b c$} \\
\hline $\begin{array}{l}\text { June } \\
\text { July }\end{array}$ & $\begin{array}{c}8,1950 \\
19\end{array}$ & $\begin{array}{l}5.29 \\
5.90\end{array}$ & $\begin{array}{l}\text { Aug. } 15,1950 \\
\text { Sept. } 17\end{array}$ & $\begin{array}{l}3.61 \\
4.98\end{array}$ & $\begin{array}{c}\text { Oct. } 17,1950 \\
\text { Dec. } 6\end{array}$ & $\begin{array}{l}5.56 \\
5.72\end{array}$ \\
\hline
\end{tabular}

3-27-11cb

\begin{tabular}{|c|c|c|c|c|c||c|c|c|}
\hline June & 8,1950 & 6.35 & Aug. 15, 1950 & 5.61 & Oct. & 17, & 1950 & \\
July 19 & & 6.81 & Sept. 17 & 6.57 \\
\hline
\end{tabular}

3-27-11cc

\begin{tabular}{|l|l|l|l|l|l|l|l|l|}
\hline June & 8,1950 & 6.46 & Oct. 17,1950 & 6.73 & Dec, 6,1950 & 6.69 \\
\hline July 19 & & 6.94 & & & & \\
\hline
\end{tabular}

3-27-12bb

\begin{tabular}{|c|c|c|c|c|c|c|c|c|}
\hline $\begin{array}{l}\text { Dec. } \\
\text { Feb. } \\
\text { Nov. } \\
\text { Dec. } \\
\text { Jan. }\end{array}$ & $\begin{array}{rr}10, & 1948 \\
9, & 1949 \\
18 & \\
20 & \\
20, & 1950\end{array}$ & $\begin{array}{l}6.90 \\
6.81 \\
8.29 \\
8.23 \\
8.13\end{array}$ & $\begin{array}{l}\text { Feb. } \\
\text { May } \\
\text { June } \\
\text { July }\end{array}$ & $\begin{array}{cc}17, & 1950 \\
4 & \\
14 & \\
19 & \end{array}$ & $\begin{array}{l}7.74 \\
7.73 \\
7.62 \\
8.00\end{array}$ & $\begin{array}{l}\text { Aug. } \\
\text { Sept. } \\
\text { Oct. } \\
\text { Dec. }\end{array}$ & $\begin{aligned} 15, & 1950 \\
17 & \\
17 & \\
6 & \end{aligned}$ & $\begin{array}{l}5.12 \\
6.41 \\
7.12 \\
7.47\end{array}$ \\
\hline
\end{tabular}

3-27-12cc

\begin{tabular}{|r|r||l|l|l|l|l|l|l|}
\hline June & 8,1950 & 13.47 & Aug. 14, 1950 & 12.81 & Oct. & 18, & 1950 & 13.59 \\
July & 18 & 13.74 & Sept. 19 & 13.34 & Dec. & 5 & 13.43 \\
\hline
\end{tabular}

\begin{tabular}{|c|c|c|c|c|c|c|c|c|}
\hline \multicolumn{9}{|c|}{$3-27-14 a b$} \\
\hline $\begin{array}{l}\text { Feb. } \\
\text { Apr. } \\
\text { June } \\
\text { Aug. } \\
\text { Oct. } \\
\text { Dec. } \\
\text { June }\end{array}$ & $\begin{array}{ll}2, & 1948 \\
9 & \\
7 & \\
2 & \\
4 & \\
6 & \\
6, & 1949\end{array}$ & $\begin{array}{l}16.42 \\
16.77 \\
17.08 \\
17.35 \\
17.90 \\
17.10 \\
16.70\end{array}$ & $\begin{array}{l}\text { Aug. } \\
\text { Oct. } \\
\text { Nov. } \\
\text { Dec. } \\
\text { Jan. } \\
\text { Mar. }\end{array}$ & $\begin{array}{cc}1, & 1949 \\
3 & \\
15 & \\
17 & \\
19, & 1950 \\
8 & \end{array}$ & $\begin{array}{l}17.49 \\
17.52 \\
17.14 \\
16.88 \\
16.50 \\
16.79\end{array}$ & $\begin{array}{l}\text { May } \\
\text { June } \\
\text { July } \\
\text { Aug. } \\
\text { Oct. } \\
\text { Dec. }\end{array}$ & $\begin{array}{rr}2, & 1950 \\
9 & \\
18 & \\
14 & \\
18 & \\
5 & \end{array}$ & $\begin{array}{l}16.97 \\
17.10 \\
17.34 \\
16.54 \\
17.35 \\
17.08\end{array}$ \\
\hline
\end{tabular}


GROUND-WATER GEOLOGY, REPUBLICAN AND FRENCHMAN VALLEYS, NEBR. 687

Water-level measurements in wells, in feet below land-surface datum, with recorder chart readings of lowest daily water levels in 1950-Continued

\begin{tabular}{c|c||c|c||c|c}
\hline Date & $\begin{array}{l}\text { Water } \\
\text { level }\end{array}$ & Date & $\begin{array}{l}\text { Water } \\
\text { level }\end{array}$ & Date & $\begin{array}{l}\text { Water } \\
\text { level }\end{array}$ \\
\hline
\end{tabular}

RED WILLOW COUNTY-Continued

$$
3-27-16 \text { ad }
$$

\begin{tabular}{|c|c||c|c||cc|c}
\hline June & 9,1950 & 10.92 & Aug. 14, 1950 & 10.66 & Oct. 18, 1950 & 11.27 \\
July 18 & 11.16 & Sept. 19 & 11.19 & Dec. 5 & 11.05 \\
\hline
\end{tabular}

\begin{tabular}{|c|c|c|c|c|c|c|c|c|}
\hline \multicolumn{9}{|c|}{$3-27-17 c b$} \\
\hline $\begin{array}{l}\text { Feb. } \\
\text { Apr. } \\
\text { June } \\
\text { Aug. } \\
\text { Oct. } \\
\text { Dec. } \\
\text { Feb. } \\
\text { Apr. }\end{array}$ & $\begin{array}{ll}2, & 1948 \\
9 & \\
7 & \\
2 & \\
4 & \\
6 & \\
7, & 1949 \\
7 & \end{array}$ & $\begin{array}{r}9.65 \\
9.47 \\
9.77 \\
9.62 \\
10.65 \\
10.17 \\
10.01 \\
8.51\end{array}$ & $\begin{array}{l}\text { June } \\
\text { Aug. } \\
\text { Oct. } \\
\text { Nov. } \\
\text { Dec. } \\
\text { Jan. } \\
\text { Mar. }\end{array}$ & $\begin{array}{rr}6, & 1949 \\
1 & \\
3 & \\
15 & \\
17 & \\
19, & 1950 \\
8 & \end{array}$ & $\begin{array}{r}9.90 \\
9.89 \\
10.27 \\
9.87 \\
9.68 \\
9.31 \\
9.12\end{array}$ & $\begin{array}{l}\text { May } \\
\text { June } \\
\text { July } \\
\text { Aug. } \\
\text { Sept. } \\
\text { Oct. } \\
\text { Dec. }\end{array}$ & $\begin{aligned} 2, & 1950 \\
9 & \\
18 & \\
14 & \\
19 & \\
18 & \\
5 & \end{aligned}$ & $\begin{array}{l}9.32 \\
9.25 \\
9.83 \\
8.61 \\
9.61 \\
9.84 \\
9.71\end{array}$ \\
\hline
\end{tabular}

$3-27-18 \mathrm{bc} 2$

\begin{tabular}{|l|l||l|l||l|l|l}
\hline June & 8,1950 & 6.84 & Aug. 15, 1950 & 6.59 & Oct. 17, 1950 & $\begin{array}{c}7.24 \\
\text { July } 19\end{array}$ \\
\hline
\end{tabular}

\section{3-27-18ca}

\begin{tabular}{|l|l||l|l||lc|r}
\hline June & 8,1950 & 6.39 & Aug. 15, 1950 & 6.07 & Oct. 17, 1950 & 6.75 \\
July 19 & 6.67 & Sept. 17 & 6.53 & Dec. 5 & 6.42 \\
\hline
\end{tabular}

\section{$3-28-5 c d$}

\begin{tabular}{l|l||l|l||l|l|l}
\hline Oct. 13, 1950 & 26.20 & Oct. 17,1950 & 26.28 & Dec. 5, 1950 & 25.59 \\
\hline
\end{tabular}

$3-28-8 c a$

\begin{tabular}{lr|r||l|r||l|l}
\hline June & 9,1950 & 23.78 & Sept. 16, 1950 & 24.92 & Oct. 28, 1950 & 25.02 \\
July 19 & 24.70 & Sept. 17 & 24.89 & Nov. 11 & 24.88 \\
Aug. 5 & 23.86 & Sept. 23 & 25.07 & Nov. 18 & 24.80 \\
Aug. 13 & 24.20 & Sept. 30 & 25.14 & Nov. 24 & 24.80 \\
Aug. 15 & 24.29 & Oct. 7 & 25.15 & Dec. 2 & 24.60 \\
Aug. 19 & 24.48 & Oct. 13 & 25.16 & Dec. 9 & 24.55 \\
Aug. 26 & 24.74 & Oct. 17 & 25.14 & Dec. 16 & 24.43 \\
Sept. 2 & 24.84 & Oct. 21 & 25.11 & Dec. 22 & 24.42 \\
\hline
\end{tabular}

$3-28-8 \mathrm{dc}$

\begin{tabular}{|l|l||l|l||lr|r}
\hline June & 9,1950 & 18.30 & Aug. 15, 1950 & 18.84 & Oct. 17, 1950 & 19.59 \\
July 19 & 19.14 & Sept. 17 & 19.34 & Dec. 5 & 18.95 \\
\hline
\end{tabular}

$3-28-14 a d$

\begin{tabular}{|l|l||l|l||ll|l}
\hline June 29, 1950 & 6.55 & Oct. 17,1950 & 7.10 & Dec. 5,1950 & 6.95 \\
\hline
\end{tabular}

$3-28-14 d b$

\begin{tabular}{l|l|l|l|l||ll|l|}
\hline June 8,1950 & 4.44 & Sept. 17, 1950 & 4.94 & Dec. 5, 1950 & 4.93 \\
Aug. 15 & 4.07 & Oct. 17 & 5.23 & & \\
\hline
\end{tabular}


Water-level measurements in wells, in feet below land-surface datum, with recorder chart readings of lowest daily water levels in 1950-Continued

\begin{tabular}{c|l||l|l||l|l}
\hline Date & $\begin{array}{l}\text { Water } \\
\text { level }\end{array}$ & Date & $\begin{array}{l}\text { Water } \\
\text { level }\end{array}$ & Date & $\begin{array}{l}\text { Water } \\
\text { level }\end{array}$ \\
\hline
\end{tabular}

RED WILLOW COUNTY-Continued

\begin{tabular}{|c|r||l|l|l|l|l|r|r|}
\hline June & $9,28-15 b d$ \\
July & 19 & 1950 & 7.29 & Aug. 15,1950 & 7.81 & Oct. & 17,1950 & 8.42 \\
\hline
\end{tabular}

3-28-16bd

\begin{tabular}{|l|r||l|l||lr|r}
\hline June & 9,1950 & 10.74 & Aug. 15, 1950 & 10.87 & Oct. 17, 1950 & 11.50 \\
July 19 & 11.21 & Sept. 17 & 11.29 & Dec. 5 & 11.17 \\
\hline
\end{tabular}

3-28-17da

\begin{tabular}{|c|c|c|c|c|c|c|}
\hline $\begin{array}{l}\text { Feb. } \\
\text { Apr. } \\
\text { June } \\
\text { Aug. } \\
\text { Oct. } \\
\text { Dec. } \\
\text { Feb. } \\
\text { Apr. } \\
\text { June } \\
\text { Aug. } \\
\text { Oct. } \\
\text { Nov. } \\
\text { Dec. } \\
\text { Jan. } \\
\text { Mar. } \\
\text { May }\end{array}$ & $\begin{array}{rr}2, & 1948 \\
9 & \\
7 & \\
2 & \\
4 & \\
6 & \\
7, & 1949 \\
7 & \\
6 & \\
1 & \\
3 & \\
15 & \\
17 & \\
19, & 1950 \\
8 & \\
4 & \end{array}$ & $\begin{array}{r}10.92 \\
10.50 \\
11.35 \\
10.67 \\
11.80 \\
11.21 \\
10.72 \\
9.60 \\
9.59 \\
10.54 \\
11.52 \\
10.97 \\
10.68 \\
10.39 \\
9.95 \\
10.09\end{array}$ & $\begin{array}{lrl}\text { June } & 8, & 1950 \\
\text { July } & 19 & \\
\text { Aug. } & 5 \\
\text { Aug. } & 13 \\
\text { Aug. } & 15 \\
\text { Aug. } & 19 \\
\text { Aug. } & 26 \\
\text { Sept. } & 2 \\
\text { Sept. } & 9 \\
\text { Sept. } & 16 \\
\text { Sept. } & 17 \\
\text { Sept. } & 23 \\
\text { Sept. } & 27 \\
\text { Sept. } & 30 \\
\text { Oct. } & 7\end{array}$ & $\begin{array}{r}9.94 \\
11.09 \\
10.85 \\
10.91 \\
10.94 \\
11.12 \\
11.23 \\
11.30 \\
11.40 \\
11.38 \\
11.35 \\
11.48 \\
11.51 \\
11.50 \\
11.47\end{array}$ & 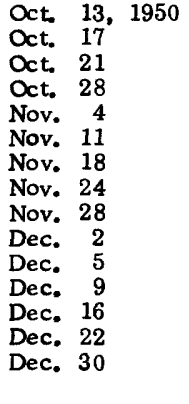 & $\begin{array}{l}11.47 \\
11.44 \\
11.41 \\
11.32 \\
11.27 \\
11.19 \\
11.08 \\
11.05 \\
10.97 \\
10.90 \\
10.92 \\
10.87 \\
10.80 \\
10.76 \\
10.71\end{array}$ \\
\hline
\end{tabular}

3-28-20ad

\begin{tabular}{|l|l||l|l||l|l|}
\hline June 13,1950 & 6.75 & Aug. 14, 1950 & 6.40 & Oct. 20, 1950 & 7.27 \\
July 18 & 6.83 & Sept. 25 & 7.20 & Dec. 11 & 6.86 \\
\hline
\end{tabular}

3-28-20ba

\begin{tabular}{|c|c||c|c||cc|c|}
\hline June & 9,1950 & 5.70 & Aug. 15, 1950 & 6.40 & Oct. 17, 1950 & 7.04 \\
July 19 & 6.85 & Sept. 17 & 7.02 & Dec. 5 & 6.58 \\
\hline
\end{tabular}

3-28-20bbc1

\begin{tabular}{l|r|r|ll|r||lr|r}
\hline Feb. & 2,1948 & 10.68 & June & 6,1949 & 9.19 & Mar. 8,1950 & 9.61 \\
Apr. & 9 & 10.30 & July & 7 & 8.99 & May 4 & 9.70 \\
June & 7 & 11.20 & Aug. & 1 & 9.65 & Jume 9 & 9.73 \\
Aug. & 2 & 10.52 & Sept. 7 & 10.30 & July 19 & 10.39 \\
Oct. 4 & 11.22 & Oct. 3 & 10.56 & Aug. 15 & 10.18 \\
Dec. 6 & 10.63 & Nov. 15 & 10.34 & Sept. 17 & 10.50 \\
Feb. 17,1949 & 9.85 & Dec. 17 & 10.06 & Oct. 17 & 10.67 \\
Apr. 7 & 8.79 & Jan. 19,1950 & 9.87 & Dec. 5 & 10.39 \\
\hline
\end{tabular}

3-28-20bbc2

\begin{tabular}{|c|c|c|c|c|c|c|c|}
\hline Day & Oct. & Nov. & Dec. & Day & Oct. & Nov. & Dec. \\
\hline $\begin{array}{l}1 \\
2 \\
3 \\
4\end{array}$ & ….......... & $\begin{array}{l}7.86 \\
7.86 \\
7.85 \\
7.78\end{array}$ & $\begin{array}{l}7.37 \\
7.41 \\
7.41 \\
7.43\end{array}$ & $\begin{array}{l}5 \\
6 \\
7 \\
8\end{array}$ & $\begin{array}{r}7.63 \\
7.65 \\
7.65\end{array}$ & $\begin{array}{l}7.79 \\
7.80 \\
7.77 \\
7.80\end{array}$ & $\begin{array}{r}7.45 \\
\ldots \ldots \ldots \ldots \ldots \\
\ldots \ldots \ldots \ldots \ldots \ldots \\
\ldots \ldots \ldots \ldots \ldots\end{array}$ \\
\hline
\end{tabular}


GROUND-WATER GEOLOGY, REPUBLICAN AND FRENCHMAN VALLEYS, NEBR. 689

Water-level measurements in wells, in feet below land-surface datum, with recorder chart readings of lowest daily water levels in 1950 - Continued

RED WLLOW COUNTY-Continued

3-28-20bbc2-Continued

\begin{tabular}{|c|c|c|c|c|c|c|c|}
\hline Day & Oct. & Nov. & Dec. & Day & Oct. & Nov. & Dec. \\
\hline $\begin{array}{r}9 \\
10 \\
11 \\
12 \\
13 \\
14 \\
15 \\
16 \\
17 \\
18 \\
19 \\
20\end{array}$ & $\begin{array}{l}7.62 \\
7.63 \\
7.65 \\
7.65 \\
7.68 \\
7.70 \\
7.72 \\
7.75 \\
7.74 \\
7.78 \\
7.79 \\
7.78\end{array}$ & $\begin{array}{l}7.79 \\
7.75 \\
7.66 \\
7.65 \\
7.64 \\
7.58 \\
7.64 \\
7.64 \\
7.56 \\
7.52 \\
7.57 \\
7.57\end{array}$ & $\begin{array}{l}7.36 \\
7.35 \\
7.30 \\
7.29 \\
7.28 \\
7.29 \\
7.30 \\
7.27 \\
7.28 \\
7.25 \\
7.25 \\
7.23\end{array}$ & $\begin{array}{l}21 \\
22 \\
23 \\
24 \\
25 \\
26 \\
27 \\
28 \\
29 \\
30 \\
31\end{array}$ & $\begin{array}{l}7.80 \\
7.79 \\
7.75 \\
7.77 \\
7.76 \\
7.77 \\
7.81 \\
7.83 \\
7.82 \\
7.81 \\
7.84\end{array}$ & $\begin{array}{r}7.52 \\
7.52 \\
7.55 \\
7.46 \\
7.46 \\
7.46 \\
7.43 \\
7.43 \\
7.42 \\
7.40\end{array}$ & $\begin{array}{l}7.23 \\
7.21 \\
7.22 \\
7.22 \\
7.26 \\
7.27 \\
7.23 \\
7.18 \\
7.20 \\
7.13 \\
7.21\end{array}$ \\
\hline
\end{tabular}

\begin{tabular}{c|l||l|l||l|l|}
\hline Date & $\begin{array}{l}\text { Water } \\
\text { level }\end{array}$ & Date & $\begin{array}{l}\text { Water } \\
\text { level }\end{array}$ & Date & $\begin{array}{l}\text { Water } \\
\text { level }\end{array}$ \\
\hline
\end{tabular}

$3-28-21 \mathrm{~cd}$

\begin{tabular}{|c|c|c|c|c|c|c|}
\hline $\begin{array}{l}\text { Feb. } \\
\text { Apr. } \\
\text { June } \\
\text { Aug. } \\
\text { Oct. } \\
\text { Dec. } \\
\text { Feb. }\end{array}$ & $\begin{array}{ll}2, & 1948 \\
9 & \\
7 & \\
2 & \\
4 & \\
6 & \\
7, & 1949\end{array}$ & $\begin{array}{l}8.95 \\
8.92 \\
9.11 \\
8.81 \\
9.41 \\
9.17 \\
8.47\end{array}$ & $\begin{array}{lrl}\text { June } & 6, & 1949 \\
\text { Aug. } & 1 & \\
\text { Oct. } & 3 & \\
\text { Nov. } & 15 & \\
\text { Dec. } & 17 & \\
\text { Jan. } & 19, & 1950 \\
\text { Mar. } & 8 & \end{array}$ & $\begin{array}{l}8.40 \\
8.83 \\
9.04 \\
8.82 \\
8.54 \\
8.38 \\
8.48\end{array}$ & $\begin{array}{lrl}\text { May } & 2, & 1950 \\
\text { June } & 8 & \\
\text { July } & 18 \\
\text { Aug. } & 14 \\
\text { Sept. } & 25 \\
\text { Oct. } & 20 \\
\text { Dec. } & 11\end{array}$ & $\begin{array}{l}8.64 \\
8.62 \\
8.83 \\
8.43 \\
8.91 \\
8.97 \\
8.80\end{array}$ \\
\hline \multicolumn{7}{|c|}{$3-28-24 a c$} \\
\hline $\begin{array}{l}\text { Aug. } \\
\text { Oct. } \\
\text { Nov. } \\
\text { Dec. } \\
\text { Jan. }\end{array}$ & $\begin{array}{rr}1, & 1949 \\
3 & \\
15 & \\
17 & \\
19, & 1950\end{array}$ & $\begin{array}{l}13.52 \\
14.12 \\
12.66 \\
12.24 \\
12.38\end{array}$ & $\begin{array}{lrr}\text { Mar. } & 8, & 1950 \\
\text { May } & 2 & \\
\text { June } & 8 & \\
\text { July } & 18 & \end{array}$ & $\begin{array}{l}11.78 \\
11.71 \\
12.16 \\
13.21\end{array}$ & $\begin{array}{ll}\text { Aug. } & 14,1950 \\
\text { Sept. } & 25 \\
\text { Oct. } 20 & \\
\text { Dec. } & 11\end{array}$ & $\begin{array}{l}12.06 \\
13.06 \\
12.75 \\
11.96\end{array}$ \\
\hline
\end{tabular}

3-28-28bb

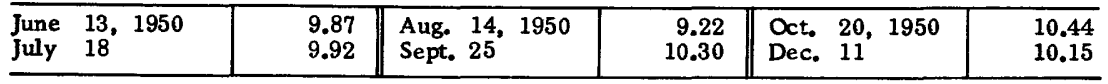

3-28-29bb

\begin{tabular}{|l|l||l|l||l|l|l}
\hline June 13,1950 & 6.35 & Aug. 14, 1950 & 6.06 & Oct. 20, 1950 & 6.84 \\
July 18 & 6.82 & Sept. 25 & 6.68 & Dec. 11 & 6.64 \\
\hline
\end{tabular}

$3-28-29 b c$

\begin{tabular}{|c|c|c|c|c|c|}
\hline $\begin{array}{lrl}\text { June } & 8, & 1950 \\
\text { July } & 18 & \\
\end{array}$ & $\begin{array}{l}5.03 \\
5.43\end{array}$ & $\begin{array}{l}\text { Aug. 14, } 1950 \\
\text { Sept. } 25\end{array}$ & $\begin{array}{l}4.64 \\
5.43\end{array}$ & $\begin{array}{ll}\text { Oct. } & 20,1950 \\
\text { Dec. } & 11\end{array}$ & $\begin{array}{l}5.57 \\
5.62\end{array}$ \\
\hline
\end{tabular}

3-28-30ca

\begin{tabular}{|l|l||l|l||l|l|}
\hline June 13,1950 & 7.62 & Aug. 14, 1950 & 6.56 & Oct. 20, 1950 & 8.06 \\
July 18 & 7.49 & Sept. 25 & 7.81 & Dec. 11 & 8.05 \\
\hline
\end{tabular}

3-28-30cd

\begin{tabular}{|c|c|c|c|c|c|}
\hline $\begin{array}{l}\text { June } \\
\text { July } \\
18\end{array}$ & $\begin{array}{l}13.47 \\
13.73\end{array}$ & $\begin{array}{l}\text { Aug. 14, } 1950 \\
\text { Sept. } 25\end{array}$ & $\begin{array}{l}13.09 \\
13.49\end{array}$ & $\begin{array}{l}\text { Oct. } 20,1950 \\
\text { Dec. } 11\end{array}$ & $\begin{array}{l}13.66 \\
13.68\end{array}$ \\
\hline
\end{tabular}


Tater-level measurements in wells, in feet below land-surface datum, with recorder chart readings of lowest daily water levels in 1950-Continued

\begin{tabular}{l|l||l|l||l|l}
\hline Date & $\begin{array}{l}\text { Water } \\
\text { level }\end{array}$ & Date & $\begin{array}{l}\text { Water } \\
\text { level }\end{array}$ & Date & $\begin{array}{l}\text { Water } \\
\text { level }\end{array}$ \\
\hline
\end{tabular}

RED WILLOW COUNTY-Continued

3-29-25cd

\begin{tabular}{|r|l||l|l|l|l|l|}
\hline June & 8,1950 & 5.79 & Aug. 14, 1950 & 5.42 & Oct. 20, 1950 & 6.91 \\
July 18 & 6.14 & Sept. 25 & 6.70 & Dec. 11 & 6.73 \\
\hline
\end{tabular}

3-29-31cc

\begin{tabular}{l|r||l|l||l|l}
\hline June 13, 1950 & 5.61 & Sept. 16, 1950 & 4.85 & Nov. 11, 1950 & 5.36 \\
July 14 & 6.11 & Sept. 22 & 5.24 & Nov. 18 & 5.19 \\
Aug. 5 & 4.87 & Sept. 30 & 5.31 & Nov. 24 & 5.31 \\
Aug. 13 & 2.77 & Oct. 7 & 5.27 & Dec. 2 & 5.23 \\
Aug. 19 & 3.89 & Oct. 13 & 5.32 & Dec. 7 & 5.18 \\
Aug. 26 & 4.50 & Oct. 20 & 5.25 & Dec. 16 & 5.11 \\
Sept. 2 & 4.85 & Oct. 28 & 5.35 & Dec. 22 & 5.14 \\
Sept. 9 & 5.22 & Nov. 4 & 5.35 & & \\
\hline
\end{tabular}

$3-29-32 c c$

\begin{tabular}{|l|l|l|l|l|l|l|l}
\hline June & 13,1950 & 4.41 & Sept. 22, 1950 & 4.00 & Dec. 11, 1950 & 3.83 \\
July 14 & 5.52 & Oct. 20 & 4.06 & & \\
\hline
\end{tabular}

3-29-32db

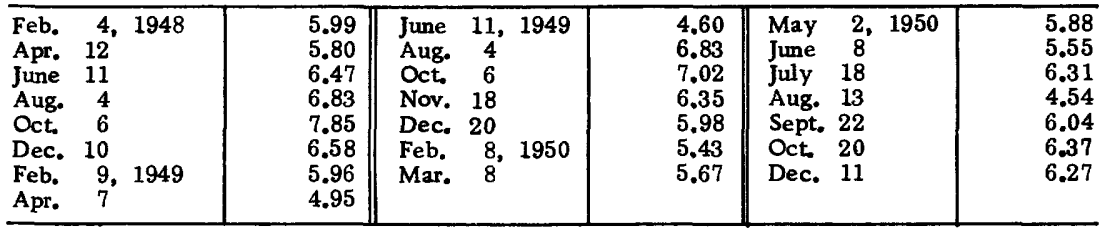

3-29-33ca

\begin{tabular}{ll|l||l|l||l|r|}
\hline May & 31,1950 & 8.54 & Aug. 13, 1950 & 7.46 & Oct. 20, 1950 & 9.12 \\
July 18 & 9.01 & Sept. 22 & 8.96 & Dec. 11 & 9.15 \\
\hline
\end{tabular}

$3-29-34 c b$

\begin{tabular}{ll|l||l|l||l|r|r}
\hline June 13,1950 & $\begin{array}{l}3.38 \\
\text { July } 18\end{array}$ & 3.08 & $\begin{array}{l}\text { Aug. 13, 1950 } \\
\text { Sept. 22 }\end{array}$ & $\begin{array}{l}2.08 \\
3.24\end{array}$ & $\begin{array}{l}\text { Oct. 20, 1950 } \\
\text { Dec. 11 }\end{array}$ & $\begin{array}{r}3.32 \\
3.18\end{array}$ \\
\hline \multicolumn{6}{|c|}{$3-29-35$ ad } \\
\hline June 8,1950 & $\begin{array}{l}7.20 \\
\text { July } 18\end{array}$ & Aug. 13, 1950 & 6.36 & Sept. 25, 1950 & 7.63 \\
\hline
\end{tabular}

3-29-35cc

\begin{tabular}{l|l|l|l||l|l}
\hline Sept. 14, 1950 & 15.79 & Oct. 13, 1950 & 15.88 & Nov. 24, 1950 & 15.68 \\
Sept. 16 & 15.68 & Oct. 20 & 15.85 & Dec. 2 & 15.66 \\
Sept. 23 & 15.68 & Oct. 28 & 15.87 & Dec. 9 & 15.67 \\
Sept. 25 & 15.70 & Nov. 4 & 15.78 & Dec. 11 & 15.61 \\
Sept. 30 & 15.74 & Nov. 11 & 15.79 & Dec. 16 & 15.62 \\
Oct. 7 & 15.82 & Nov. 18 & 15.68 & Dec. 22 & 15.63 \\
\hline
\end{tabular}


GROUND-WATER GEOLOGY, REPUBLICAN AND FRENCHMAN VALLEYS, NEBR. 691

Water-level measurements in wells, in feet below land-surface datum, with recorder chart readings of lowest daily water levels in 1950-Continued

\begin{tabular}{c|c||c|c||c|c}
\hline Date & $\begin{array}{l}\text { Water } \\
\text { level }\end{array}$ & Date & $\begin{array}{l}\text { Water } \\
\text { level }\end{array}$ & Date & $\begin{array}{l}\text { Water } \\
\text { level }\end{array}$ \\
\hline
\end{tabular}

RED WILLOW COUNTY-Continued

3-29-35da2

\begin{tabular}{|r|r||r|r||r|r|r}
\hline June & 8,1950 & 16.82 & Aug. 13, 1950 & 16.39 & Sept. 25, 1950 & 16.84 \\
\hline July 18 & 17.24 & & & & \\
\hline
\end{tabular}

3-29-36bc

\begin{tabular}{lr|r||l|l|l||l|l|l}
\hline Feb. & 4,1948 & 19.12 & Aug. 4, 1949 & 17.99 & May 2, 1950 & 18.50 \\
Apr. 12 & 19.02 & Oct. 7 & 18.15 & June 18 & 18.56 \\
June 11 & 19.79 & Nov. 18 & 18.42 & July 18 & 18.55 \\
Aug. & 4 & 19.61 & Dec. 20 & 18.29 & Aug. 14 & 18.24 \\
Oct. & 6 & 18.70 & Feb. 8,1950 & 18.65 & Sept. 25 & 18.26 \\
Dec. 10 & 18.33 & Mar. 8 & 18.67 & Dec. 11 & 18.71 \\
Apr. & 7,1949 & 18.84 & & & & & \\
\hline
\end{tabular}

$3-29-36 b d$

\begin{tabular}{|c|c|c|c|c|c|}
\hline $\begin{array}{l}\text { June } \\
\text { July } 18\end{array}$ & $\begin{array}{l}22.57 \\
22.67\end{array}$ & $\begin{array}{l}\text { Aug. 14, } 1950 \\
\text { Sept. 25 }\end{array}$ & $\begin{array}{l}22.48 \\
22.40\end{array}$ & $\begin{array}{ll}\text { Oct. } & 20,1950 \\
\text { Dec. } & 11\end{array}$ & $\begin{array}{l}22.58 \\
22.72\end{array}$ \\
\hline
\end{tabular}

3-30-7dd

\begin{tabular}{|l|l||l|l||l|l|l}
\hline July 10, 1950 & 25.16 & Oct. 18, 1950 & 25.09 & Dec. 6, 1950 & 24.61 \\
Sept. 18 & 25.09 & & & & \\
\hline
\end{tabular}

$3-30-17 d a$

\begin{tabular}{|c|c||l|l||ll|l}
\hline July 10,1950 & 8.32 & Sept. 18, 1950 & 7.85 & Dec. 6, 1950 & 7.91 \\
Aug. 9 & 7.48 & Oct. 18 & 7.88 & & \\
\hline
\end{tabular}

$3-30-18 b b$

\begin{tabular}{|l|l||l|l||l|l|}
\hline July 12, 1950 & $\begin{array}{l}30.35 \\
\text { Sept. } 18\end{array}$ & Oct. 18, 1950 & 27.04 & Dec. 6, 1950 & 27.16 \\
\hline
\end{tabular}

3-30-19ad

\begin{tabular}{|c|c|c|c|c|c|}
\hline $\begin{array}{l}\text { Aug. } 9,1950 \\
\text { Sept. } 18\end{array}$ & $\begin{array}{r}9.89 \\
10.29\end{array}$ & Oct. 18,1950 & 10.45 & Dec. 6,1950 & 10.20 \\
\hline \multicolumn{6}{|c|}{$3-30-19 b b$} \\
\hline $\begin{array}{lrl}\text { July } & 7, & 1949 \\
\text { Aug. } & 4 \\
\text { Oct. } & 6 \\
\text { Nov. } & 15 \\
\text { Dec. } & 17\end{array}$ & $\begin{array}{l}6.88 \\
7.59 \\
7.12 \\
6.95 \\
6.77\end{array}$ & $\begin{array}{lrl}\text { Jan. } & 19, & 1950 \\
\text { Mar. } & 6 & \\
\text { Apr. } & 14 & \\
\text { May } & 26 & \\
\text { July } & 10 & \end{array}$ & $\begin{array}{l}6.76 \\
6.62 \\
6.90 \\
6.76 \\
7.83\end{array}$ & $\begin{array}{lrl}\text { Aug. } & 9, & 1950 \\
\text { Sept. } & 18 & \\
\text { Oct. } & 18 & \\
\text { Dec. } & 6 & \end{array}$ & $\begin{array}{l}7.10 \\
7.52 \\
7.32 \\
6.99\end{array}$ \\
\hline
\end{tabular}

3-30-20aa

\begin{tabular}{l|r||l|r||l|l|}
\hline July 10, 1950 & 14.37 & Sept. 16, 1950 & 14.07 & Nov. 4, 1950 & 14.15 \\
Aug. 5 & 14.21 & Sept. 18 & 14.10 & Nov. 11 & 14.18 \\
Aug. 9 & 14.20 & Sept. 30 & 14.07 & Nov. 18 & 14.18 \\
Aug. 13 & 14.22 & Oct. 7 & 14.08 & Nov. 24 & 14.26 \\
Aug. 19 & 14.18 & Oct. 13 & 14.10 & Dec. 2 & 14.24 \\
Aug. 26 & 14.15 & Oct. 18 & 14.08 & Dec. 6 & 14.27 \\
Sept. 2 & 14.13 & Oct. 21 & 14.11 & Dec. 16 & 14.29 \\
Sept. 9 & 14.12 & Oct. 28 & 14.14 & Dec. 22 & 14.31 \\
\hline
\end{tabular}


Water-level measurements in wells, in feet below land-surface datum, with recorder chart readings of lowest daily water levels in 1950-Continued

\begin{tabular}{c|c||l|l||l|l|}
\hline Date & $\begin{array}{l}\text { Water } \\
\text { level }\end{array}$ & Date & $\begin{array}{l}\text { Water } \\
\text { level }\end{array}$ & Date & $\begin{array}{l}\text { Water } \\
\text { level }\end{array}$ \\
\hline
\end{tabular}

RED WILLOW COUNTY-Continued

$3-30-20 b b$

\begin{tabular}{l|l|l|l|l||l|l|l}
\hline July 10,1950 & 18.12 & Sept. 18, 1950 & 17.98 & Dec. 6, 1950 & 18.15 \\
Aug. 9 & 17.76 & Oct. 18 & 18.06 & & \\
\hline
\end{tabular}

3-30-21cb

\begin{tabular}{l|l|l||l|l||l|l|l}
\hline July 10,1950 & 9.00 & Sept. 18, 1950 & 8.90 & Dec. 6,1950 & 8.86 \\
Aug. 9 & 7.95 & Oct. 18 & 9.07 & & & \\
\hline
\end{tabular}

3-30-21da

\begin{tabular}{l|l|l|l|l|l|l|l|l}
\hline July 10,1950 & 6.36 & Sept. 18, 1950 & 6.11 & Dec. 6, 1950 & 6.60 \\
Aug. 9 & 4.97 & Oct. 18 & 6.52 & & \\
\hline
\end{tabular}

3-30-25dd

\begin{tabular}{l|r||l|l||l|r|r}
\hline July 10,1950 & 7.41 & Sept. 16, 1950 & 6.87 & Nov. 4, 1950 & 7.30 \\
Aug. 5 & 5.91 & Sept. 18 & 6.86 & Nov. 11 & 7.29 \\
Aug. 9 & 5.27 & Sept. 30 & 7.08 & Nov. 18 & 7.24 \\
Aug. 13 & 5.61 & Oct. 7 & 7.11 & Nov. 24 & 7.23 \\
Aug. 19 & 5.97 & Oct. 13 & 7.17 & Dec. 2 & 7.17 \\
Aug. 26 & 6.25 & Oct. 18 & 7.19 & Dec. 6 & 7.15 \\
Sept. 2 & 6.46 & Oct. 21 & 7.23 & Dec. 16 & 7.10 \\
Sept. 9 & 6.70 & Oct. 28 & 7.29 & Dec. 22 & 7.02 \\
\hline
\end{tabular}

$3-30-26 b c$

\begin{tabular}{ll|r||lr|r||lr|r}
\hline Feb. & 2,1948 & 8.22 & Apr. 4,1949 & 7.78 & Apr. 12, 1950 & 8.24 \\
Apr. & 9 & 8.35 & June & 6 & 8.15 & June 8 & 8.45 \\
June & 7 & 8.85 & Oct. & 3 & 9.30 & July 10 & 9.32 \\
Aug. & 2 & 9.75 & Nov. 15 & 8.65 & Aug. 9 & 8.47 \\
Oct. & 4 & 10.35 & Dec. 17 & 8.57 & Sept. 18 & 8.82 \\
Dec. & 6 & 10.08 & Feb. & 8,1950 & 7.49 & Oct. 18 & 9.01 \\
Feb. & 7,1949 & 7.45 & Mar. 8 & 8.14 & Dec. 6 & 8.78 \\
\hline
\end{tabular}

3-30-26da

\begin{tabular}{l|l|l|l|l||l|l|l}
\hline July 10,1950 & 4.31 & Sept. 8, 1950 & 4.41 & Dec. 6, 1950 & 4.13 \\
Aug. 9 & 2.97 & Oct. 18 & 4.64 & & & \\
\hline
\end{tabular}

3-30-28cbb

\begin{tabular}{|l|l||l|l||l|r|r}
\hline June 19,1950 & 11.66 & Aug. 13, 1950 & 12.29 & Oct. 20, 1950 & 12.43 \\
July 14 & 12.38 & Sept. 22 & 11.99 & Dec. 7 & 12.53 \\
\hline
\end{tabular}

3-30-29aa

\begin{tabular}{|c|c|c|c|c|c|c|c|c|}
\hline $\begin{array}{l}\text { Feb. } \\
\text { Apr. } \\
\text { June } \\
\text { Aug. } \\
\text { Oct. } \\
\text { Dec. } 1 \\
\text { Feb. } \\
\text { Apr. }\end{array}$ & $\begin{aligned} 4, & 1948 \\
12 & \\
11 & \\
4 & \\
6 & \\
10 & \\
9, & 1949 \\
7 & \end{aligned}$ & $\begin{array}{l}3.86 \\
3.49 \\
4.20 \\
4.62 \\
5.03 \\
4.17 \\
3.55 \\
1.92\end{array}$ & $\begin{array}{l}\text { June } \\
\text { July } \\
\text { Aug. } \\
\text { Sept. } \\
\text { Oct. } \\
\text { Nov. } 1 \\
\text { Dec. } 2 \\
\text { Feb. }\end{array}$ & $\begin{aligned} 11, & 1949 \\
7 & \\
4 & \\
12 & \\
7 & \\
18 & \\
20 & \\
8, & 1950\end{aligned}$ & $\begin{array}{l}2.35 \\
3.63 \\
4.68 \\
4.35 \\
4.56 \\
3.97 \\
3.75 \\
3.11\end{array}$ & $\begin{array}{ll}\text { Mar. } & \\
\text { Apr. } & 1 \\
\text { June } & \\
\text { July } & 1 \\
\text { Aug. } & \\
\text { Sept. } & 1 \\
\text { Oct. } & 2 \\
\text { Dec. } & \end{array}$ & $\begin{aligned} 8, & 1950 \\
12 & \\
8 & \\
10 & \\
9 & \\
18 & \\
20 & \\
6 & \end{aligned}$ & $\begin{array}{l}2.92 \\
3.09 \\
3.23 \\
3.89 \\
3.26 \\
4.24 \\
4.19 \\
3.81\end{array}$ \\
\hline
\end{tabular}


GROUND-WATER GEOLOGY, REPUBLICAN AND FRENCHMAN VALLEYS, NEBR, 693

Water-level measurements in wells, in feet below landasurface datum, with recorder chart readings of lowest daily water levels in 1950-Continued

\begin{tabular}{c|c||l|l||l|l}
\hline Date & $\begin{array}{l}\text { Water } \\
\text { level }\end{array}$ & Date & $\begin{array}{l}\text { Water } \\
\text { level }\end{array}$ & Date & $\begin{array}{l}\text { Water } \\
\text { level }\end{array}$ \\
\hline
\end{tabular}

RED WILLOW COUNTY-Continued

\begin{tabular}{|l|l||l|l||l|r|r}
\hline June & 19,1950 & 10.69 & Aug. 12, 1950 & 11.18 & Oct. 20, 1950 & 11.76 \\
July 14 & 11.19 & Sept. 22 & 11.57 & Dec. 7 & 11.80 \\
\hline
\end{tabular}

\begin{tabular}{|l|l|l|l|l||lr|r}
\hline 3une 19, 1950 & 11.01 & Aug. 13, 1950-33ab & 11.99 & Oct. 20, 1950 & 11.46 \\
July 14 & 11.40 & Sept. 22 & 11.25 & Dec. 7 & 11.55 \\
\hline
\end{tabular}

$3-30-34 a a$

\begin{tabular}{|c|c|c|c|c|c|c|}
\hline $\begin{array}{l}\text { June } \\
\text { July }\end{array}$ & $\begin{array}{l}19,1950 \\
14\end{array}$ & $\begin{array}{l}5.18 \\
5.49\end{array}$ & $\begin{array}{l}\text { Aug, } 13,1950 \\
\text { Sept. } 22\end{array}$ & $\begin{array}{l}4.73 \\
5.62\end{array}$ & $\begin{array}{lrl}\text { Oct, } & 20, & 1950 \\
\text { Dec. } & 7\end{array}$ & $\begin{array}{l}5.47 \\
5.11\end{array}$ \\
\hline \multicolumn{7}{|c|}{$3-30-34 b b$} \\
\hline $\begin{array}{l}\text { Feb. } \\
\text { Apr. } \\
\text { June } \\
\text { Oct. } \\
\text { Dec. } \\
\text { Feb. } \\
\text { Apr. } \\
\text { June }\end{array}$ & $\begin{array}{rr}4, & 1948 \\
12 & \\
11 & \\
6 & \\
10 & \\
9, & 1949 \\
7 & \\
11 & \end{array}$ & $\begin{array}{l}13.42 \\
13.30 \\
14.10 \\
14.73 \\
14.02 \\
13.46 \\
12.86 \\
12.53\end{array}$ & $\begin{array}{lrl}\text { July } & 7, & 1949 \\
\text { Aug. } & 4 & \\
\text { Sept. } & 12 & \\
\text { Oct. } & 7 & \\
\text { Nov. } & 18 & \\
\text { Dec. } & 20 & \\
\text { Feb. } & 8, & 1950 \\
\text { Mar. } & 8 & \end{array}$ & $\begin{array}{l}13.30 \\
15.12 \\
14.27 \\
14.30 \\
13.85 \\
13.73 \\
13.20 \\
13.21\end{array}$ & $\begin{array}{lrl}\text { Apr. } & 12, & 1950 \\
\text { Jume } & 8 & \\
\text { July } & 14 & \\
\text { Aug. } & 13 & \\
\text { Sept. } & 22 \\
\text { Oct. } & 20 & \\
\text { Dec. } & 7 & \end{array}$ & $\begin{array}{l}13.34 \\
13.12 \\
14.01 \\
13.47 \\
13.95 \\
13.90 \\
13.67\end{array}$ \\
\hline
\end{tabular}

\section{$3-30-35 c b$}

\begin{tabular}{ll|l|l|l||lr|r}
\hline June 19,1950 & 5.88 & Aug. 13, 1950 & 5.42 & Oct, 20, 1950 & 6.28 \\
July 14 & 6.15 & Sept. 22 & 6.34 & Dec. 7 & 5.96 \\
\hline
\end{tabular}

3-30-35cd

\begin{tabular}{ll|l||l|l||lr|r}
\hline June 19,1950 & 19.25 & $\begin{array}{l}\text { Aug. 13, 1950 } \\
\text { July } 14\end{array}$ & 19.57 & $\begin{array}{l}19.14 \\
\text { Sept. 22 }\end{array}$ & 19.46 & Oct. 20, 1950 & $\begin{array}{r}19.65 \\
\text { Dec. } 7\end{array}$ \\
\hline
\end{tabular}

3-30-35db

\begin{tabular}{|l|l||l|l||lr|r}
\hline June 19,1950 & 5.28 & Aug. 13, 1950 & 4.80 & Oct, 20, 1950 & 5.65 \\
July 14 & 5.65 & Sept. 22 & 5.57 & Dec. 7 & 5.40 \\
\hline
\end{tabular}

3-30-35dc

\begin{tabular}{|l|l|l|l|l|l|l|l}
\hline June 19,1950 & 14.91 & $\begin{array}{l}\text { A ug. 13, 1950 } \\
\text { Sept. 22 }\end{array}$ & $\begin{array}{l}14.18 \\
\text { July } 14\end{array}$ & 15.31 & $\begin{array}{l}\text { Oct. 20, 1950 } \\
\text { Sec. } 7\end{array}$ & $\begin{array}{l}15.22 \\
15.07\end{array}$ \\
\hline
\end{tabular}

3-30-36ca

\begin{tabular}{|l|l|l|l|l||lr|r}
\hline June & 19,1950 & 5.56 & Aug. 13, 1950 & 4.17 & Oct. 20, 1950 & 5.87 \\
July 14 & 5.84 & Sept. 22 & 5.81 & Dec. 7 & 5.69 \\
\hline
\end{tabular}

3-30-36cc

\begin{tabular}{|l|r|r|r||lr|r}
\hline June & 19,1950 & 10.73 & Aug. 13, 1950 & 9.08 & Oct. 20, 1950 & 11.07 \\
July 14 & 11.09 & Sept. 22 & 10.85 & Dec. 7 & 10.67 \\
\hline
\end{tabular}


Water-level measurements in wells, in feet below land-surface datum, with recorder chart readings of lowest daily water levels in 1950 - Continued

\begin{tabular}{c|c||l|l||l|l}
\hline Date & $\begin{array}{l}\text { Water } \\
\text { level }\end{array}$ & Date & $\begin{array}{l}\text { Water } \\
\text { level }\end{array}$ & Date & $\begin{array}{l}\text { Water } \\
\text { level }\end{array}$ \\
\hline
\end{tabular}

RED WILLOW COUNTY-Continued

4-26-34db

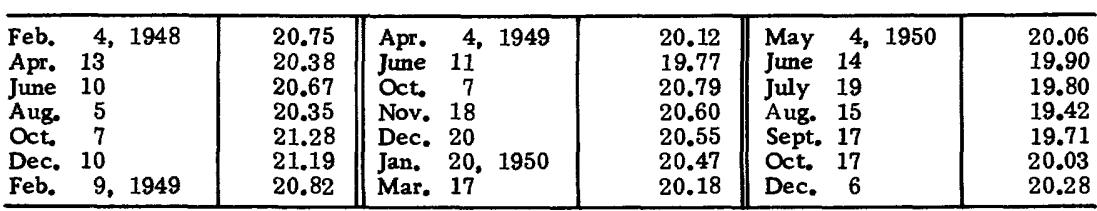

4-26-34dc

\begin{tabular}{|l|l||l|l|l|l|l|}
\hline June & 14,1950 & 11.84 & Aug. 15, 1950 & 12.14 & Oct. 17, 1950 & 12.11 \\
July 19 & 11.60 & Sept. 17 & 11.73 & Dec. 6 & 12.23 \\
\hline
\end{tabular}

4-26-35ad

\begin{tabular}{|l|l||l|l||lr|r}
\hline June 14,1950 & 10.60 & Aug. 15, 1950 & 10.15 & Oct. 17, 1950 & 11.02 \\
July 19 & 10.52 & Sept. 17 & 10.50 & Dec. 6 & 11.25 \\
\hline
\end{tabular}

$4-26-35 d b$

\begin{tabular}{|l|l||l|l||lr|r|}
\hline June 14,1950 & 6.85 & Aug. 15, 1950 & 6.78 & Oct. 17, 1950 & 7.60 \\
July 19 & 7.09 & Sept. 17 & 7.38 & Dec. 6 & 7.67 \\
\hline
\end{tabular}


A P PENDIX B 


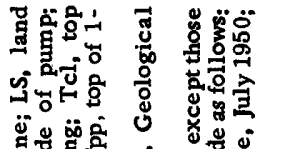

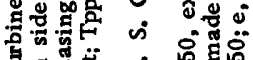

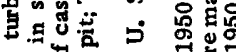
○

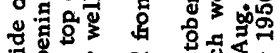

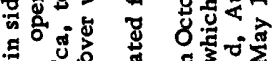
o की है

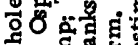

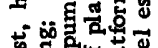


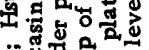

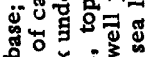

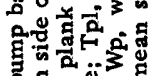
a. 1 .5ं

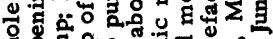

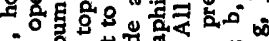

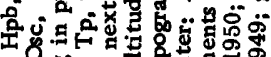

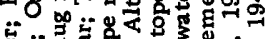

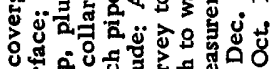

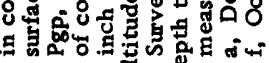

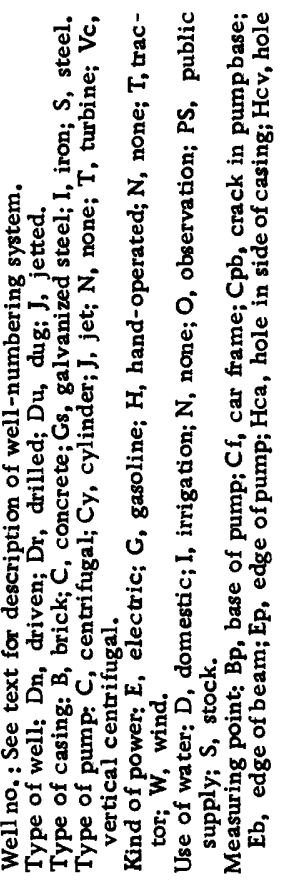

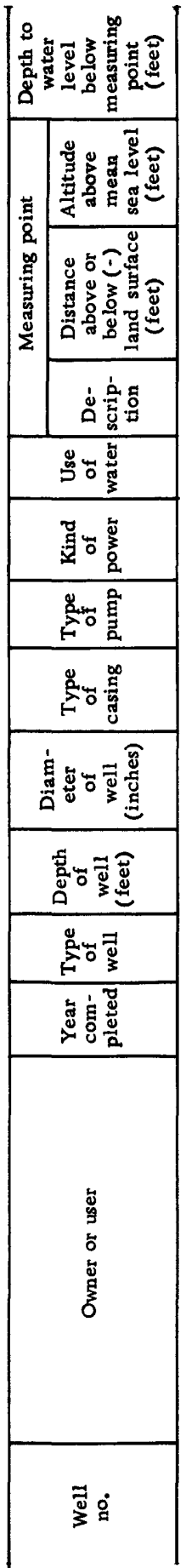

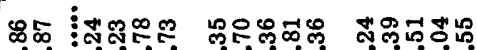

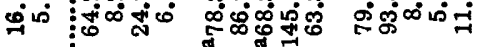

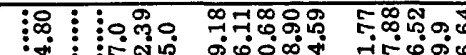

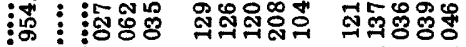

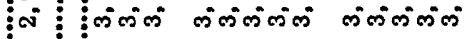

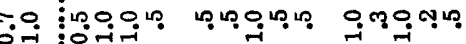

\begin{tabular}{|c|c|c|}
\hline 品品品品品 & 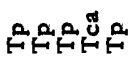 & 品品品员 \\
\hline 0 ozooo & 000 & D \\
\hline
\end{tabular}

$z z=z z z z \quad z z z z z \quad z z z z z$

$z z+z z z z \quad z z z z z \quad z z z z z$ ปั

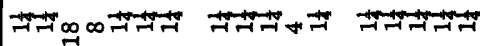

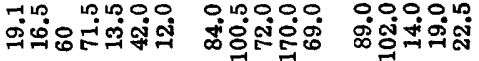

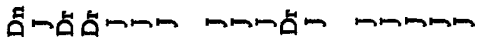

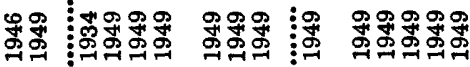

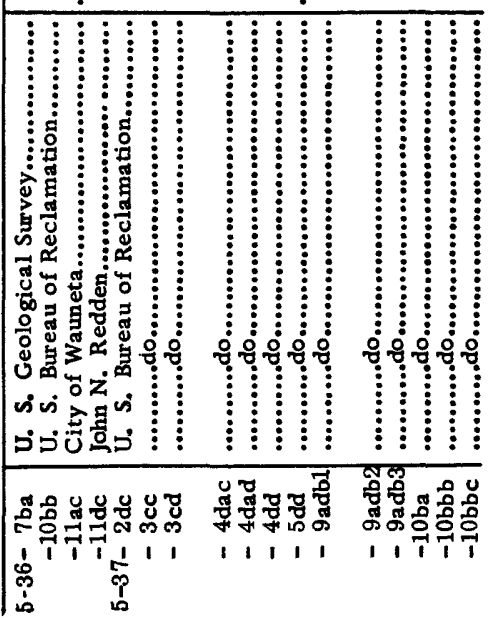


GROUND-WATER GEOLOGY, REPUBLICAN AND FRENCHMAN VALLEYS, NEBR, 697

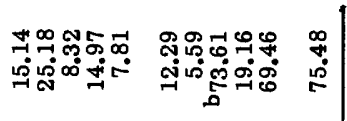

\begin{tabular}{|c|c|}
\hline 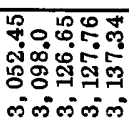 & 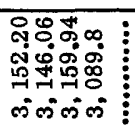 \\
\hline न几 & 0.0 \\
\hline
\end{tabular}

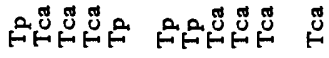

00000000000

zZzZZ zZZZZ Z

$\mathbf{Z Z Z Z Z Z Z Z Z Z Z Z Z Z ~}$

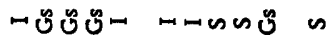

\#ம000

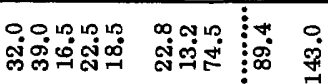

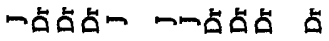

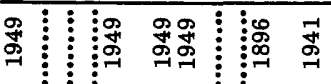

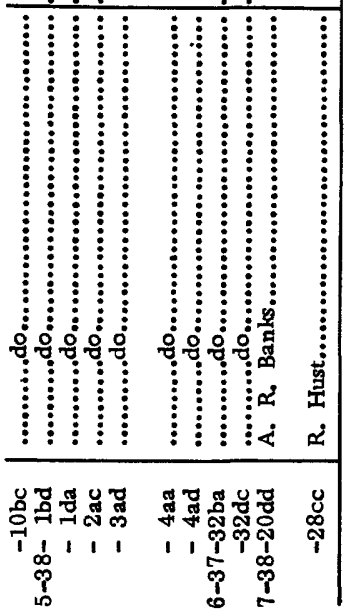

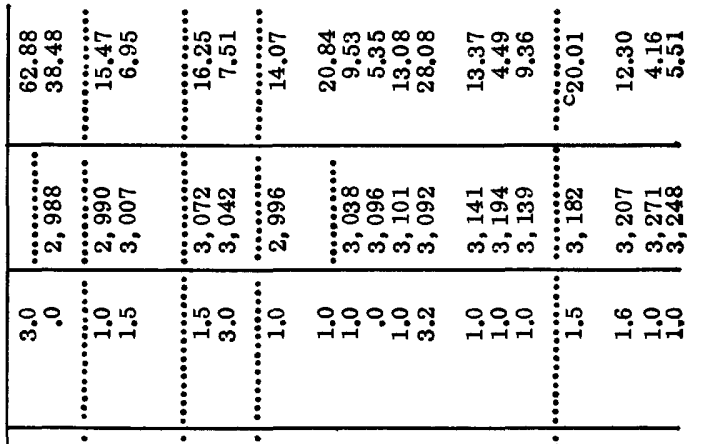

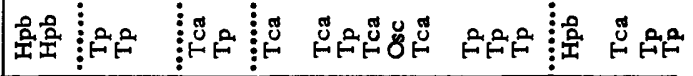

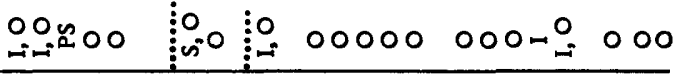
U山wzz HHHzZ

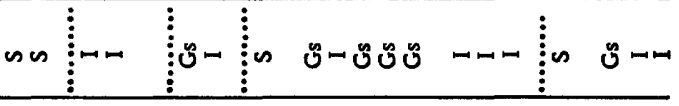

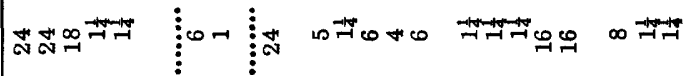

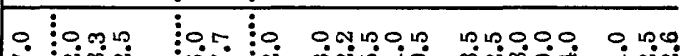
:

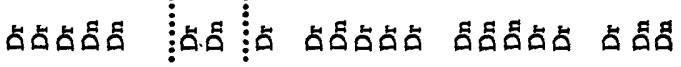

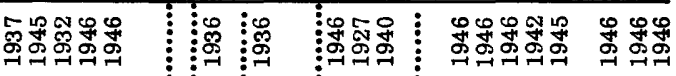

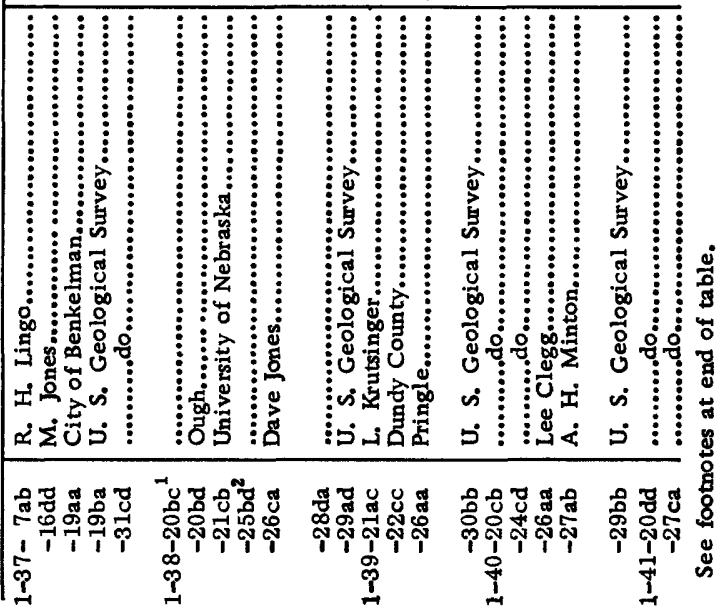




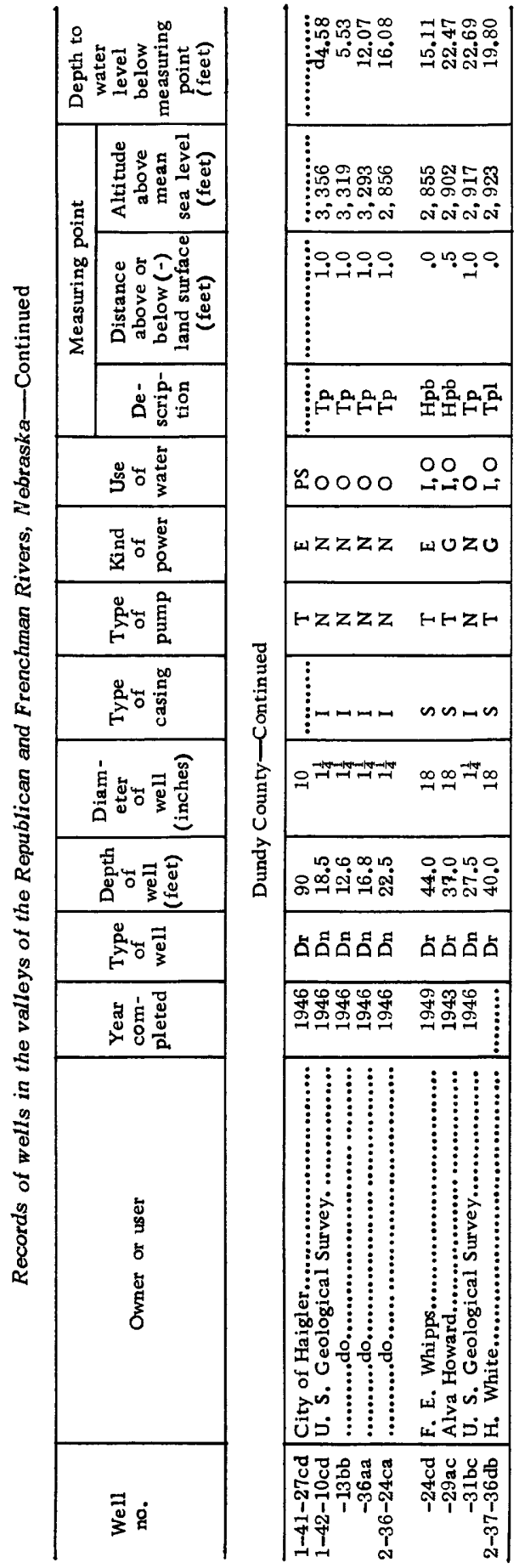

\begin{tabular}{|c|c|c|}
\hline 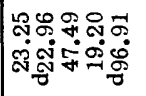 & 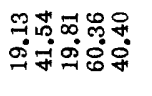 & 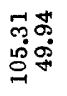 \\
\hline 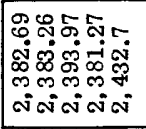 & 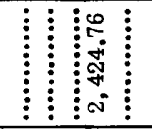 & $\begin{array}{c}\infty \\
\vdots \vdots \\
\vdots \\
\vdots \\
\vdots \\
\vdots \\
\vdots \\
\vdots \\
\vdots\end{array}$ \\
\hline 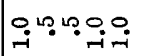 & $: 0$. & น. \\
\hline 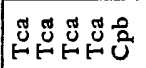 & 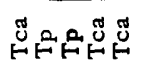 & 导 \\
\hline 10000 & 0 & 00 \\
\hline$z z z z_{3}$ & $z: x$ & $3 z$ \\
\hline$z z z z \hat{U}$ & $z \vec{u}$ & $\vec{u} z$ \\
\hline نَ & ర̋ & రิن \\
\hline מ & מי & מ מ מ מ \\
\hline 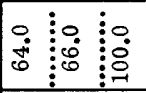 & \begin{tabular}{l:c} 
\\
\hdashline \\
$\vdots$ \\
$\vdots$
\end{tabular} & مَّ \\
\hline 占占占占 & 草台 & 占台 \\
\hline & & \\
\hline 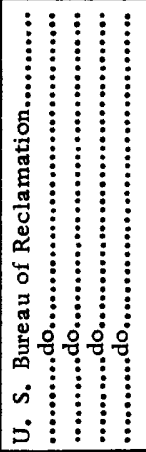 & 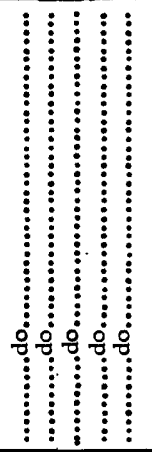 & 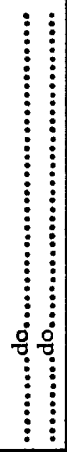 \\
\hline 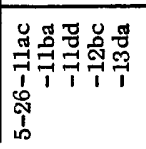 & 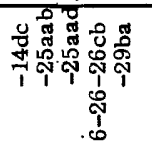 & 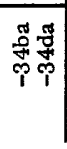 \\
\hline
\end{tabular}




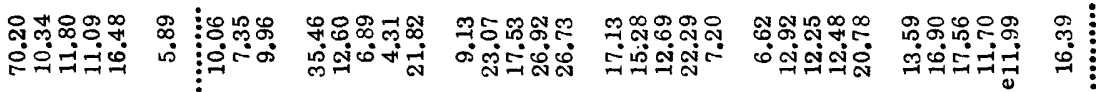

\begin{tabular}{|c|c|c|c|c|c|c|}
\hline 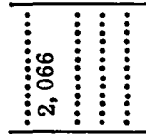 & 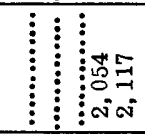 & 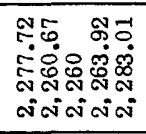 & 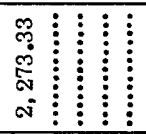 & $\begin{array}{c:c}\vdots \\
\vdots \\
\vdots \\
\vdots \\
\vdots \\
\vdots \\
\vdots \\
\vdots \\
\vdots\end{array}$ & 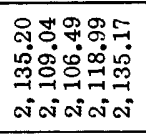 & 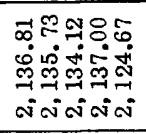 \\
\hline 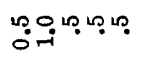 & 战 & 0.070 .00 & 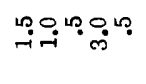 & 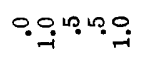 & 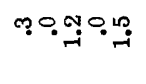 & 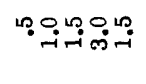 \\
\hline
\end{tabular}

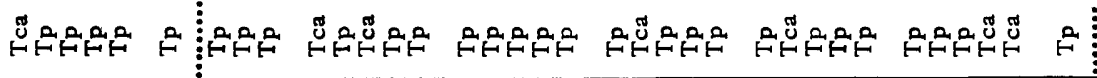
zo000 02000 000000000000000 0.9000 000 vin 0

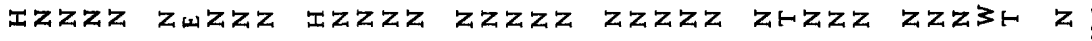
ưzzzz zHzzz Ùzzzz zzzzz zzzzz ztzzz zzzừ z ロ

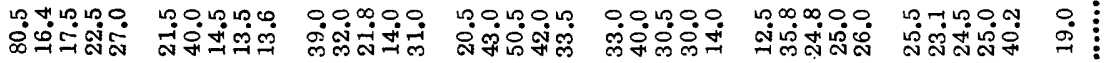

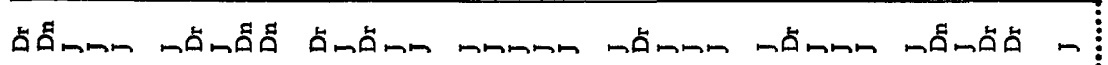

\begin{tabular}{|c|c|c|c|c|c|c|c|}
\hline 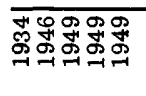 & 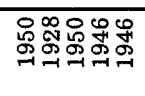 & :웅요요요 & 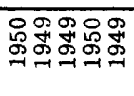 & 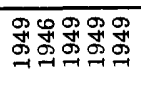 & 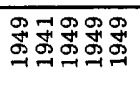 & 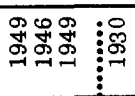 & \\
\hline 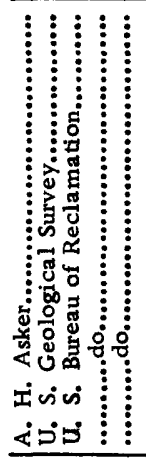 & 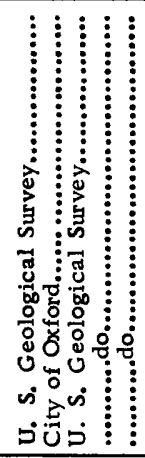 & $\begin{array}{c}\vdots \\
\vdots \\
\vdots \\
\vdots \\
\vdots \\
\vdots \\
\vdots \\
\vdots \\
\vdots \\
\vdots \\
\vdots \\
\vdots\end{array}$ & $\begin{array}{c}\vdots \\
\vdots \\
\vdots \\
\vdots \\
\vdots\end{array}$ & 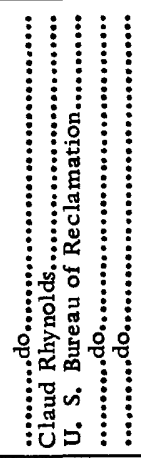 & $\begin{array}{r}\vdots \\
\vdots \\
\vdots \\
\vdots \\
\vdots \\
\vdots \\
\vdots \\
\vdots \\
\vdots \\
\vdots \\
\vdots \\
\vdots \\
\vdots \\
\vdots \\
\vdots \\
\vdots \\
\vdots \\
\vdots\end{array}$ & $\begin{array}{c}\vdots \\
\vdots \\
\vdots \\
\vdots \\
\vdots \\
\vdots\end{array}$ & 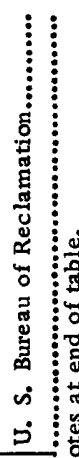 \\
\hline జ్ & 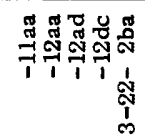 & 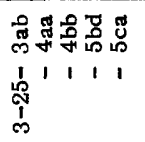 & 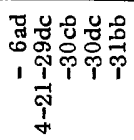 & భีศ్య & 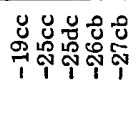 & 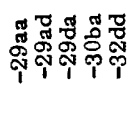 & \\
\hline
\end{tabular}




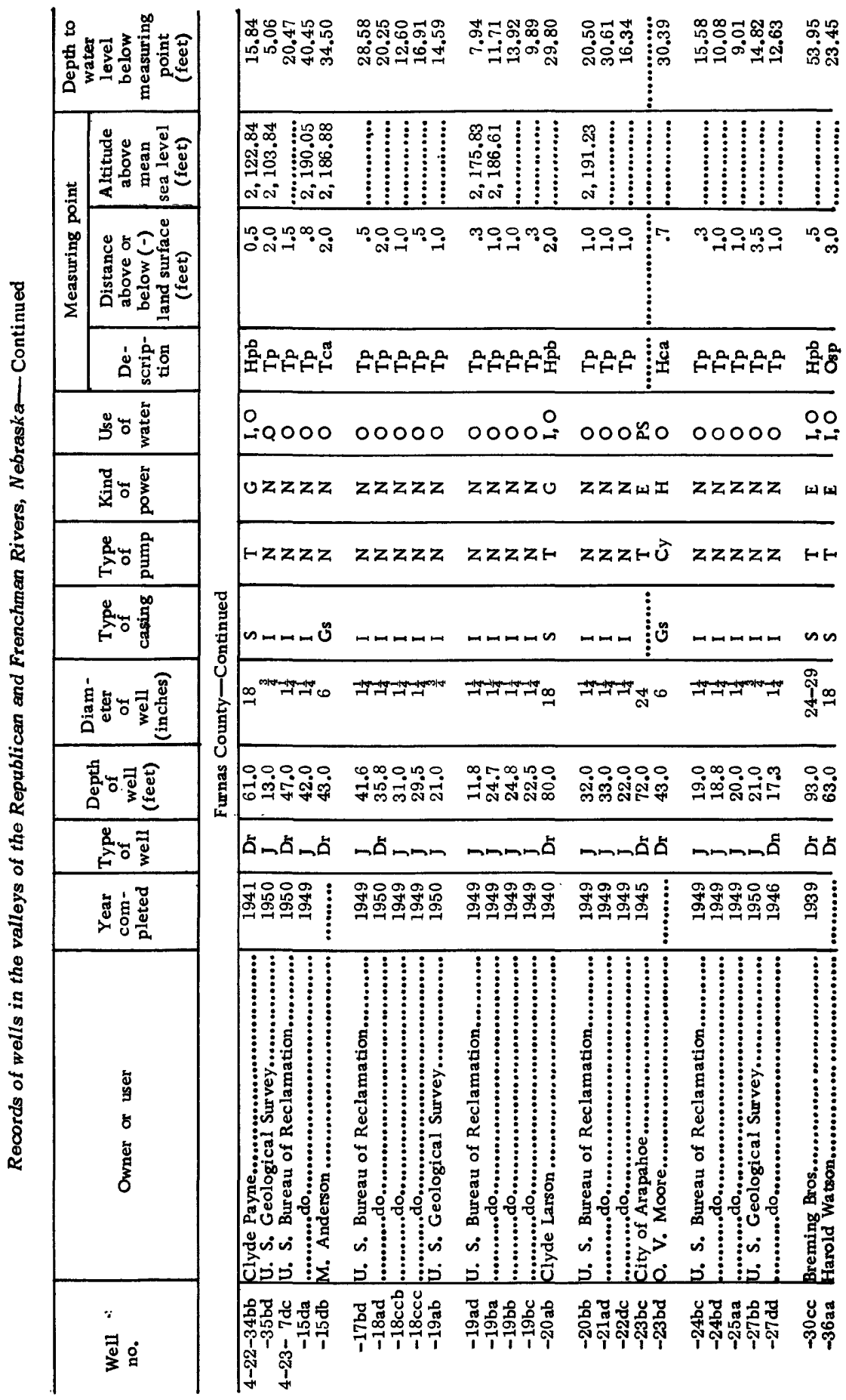


GROUND-WATER GEOLOGY, REPUBLICAN AND FRENCHMAN VALLEYS, NEBR. 701

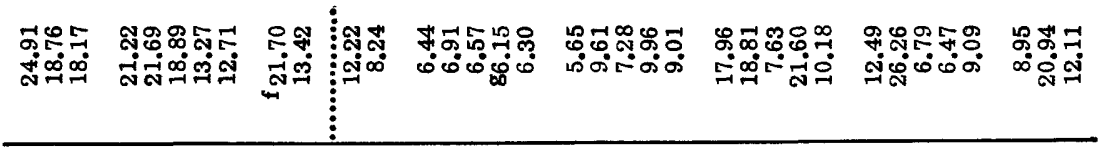

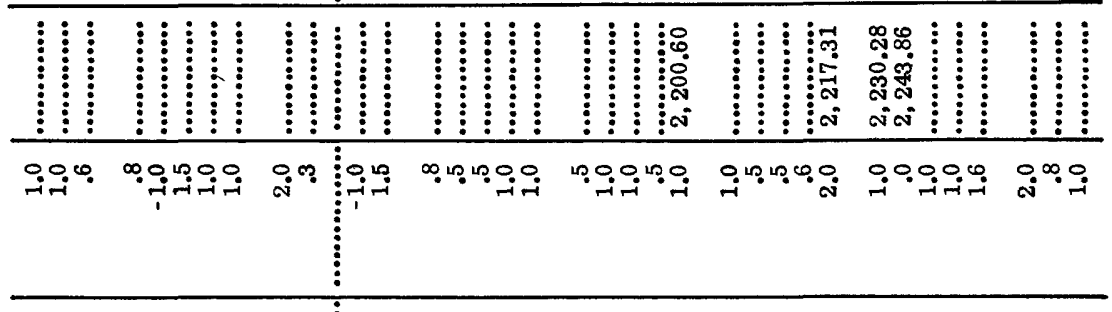

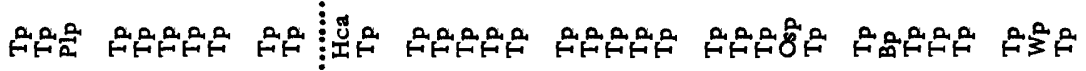

\begin{tabular}{|c|c|c|c|c|c|c|c|c|}
\hline $00 \stackrel{0}{-1}$ & 00000 & 00 & : & 00000 & 00000 & $000 \stackrel{0}{=0}$ & $0 \stackrel{0}{=0} 000$ & os 0 \\
\hline zzt & $z z z z z$ & 乙二 & 畺-z & $z z z z z$ & $z z z z z$ & $z z z-z$ & $z \cup z z z$ & $\begin{array}{l}\bar{I} \\
z \stackrel{5}{3} z\end{array}$ \\
\hline
\end{tabular}

zzH zzzzz zz

\begin{tabular}{|c|c|c|c|c|c|c|c|c|}
\hline man & ロロルロル & $\ddot{n}$ & $n$ & ロルロルロ & ルロロロロ & ローッッே & ロッேッロ & $\rightarrow \infty-$ \\
\hline 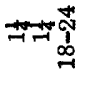 & 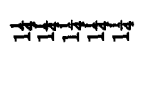 & $\rightarrow$ & สิ & 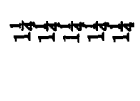 & AN & $\mathbb{N}_{-\rightarrow-1}^{\infty}$ & ${ }_{\infty}^{\infty}$ & $\ddot{Z}_{\infty}$ \\
\hline
\end{tabular}

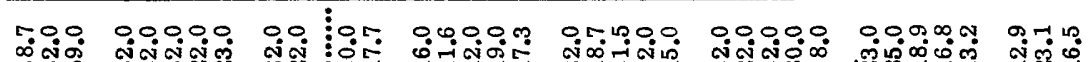

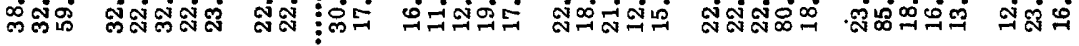

\begin{tabular}{|c|c|c|c|c|c|c|c|}
\hline مـ & ロロルーロ & 品 & ラேロロ & ロロ゙ローー & 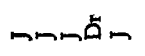 & 一 & 吕ロロ \\
\hline 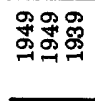 & 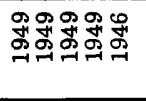 & 焉索 & 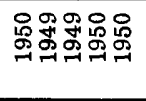 & 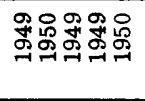 & 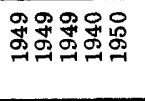 & 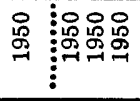 & 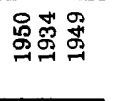 \\
\hline 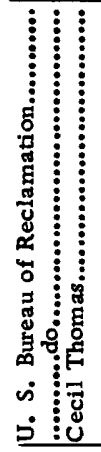 & 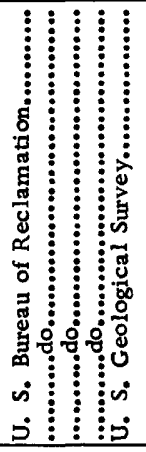 & 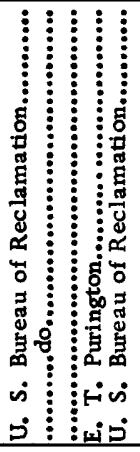 & لَ' & 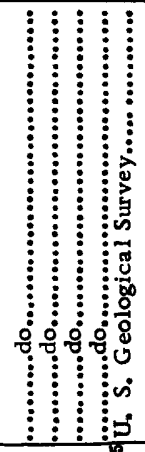 & 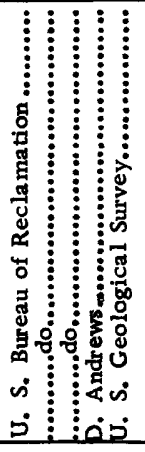 & $\begin{array}{c}0 \\
\vdots \\
\vdots \\
\vdots\end{array}$ & 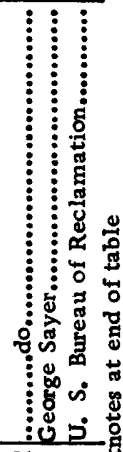 \\
\hline 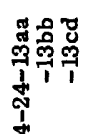 & 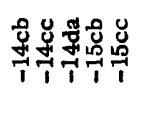 & 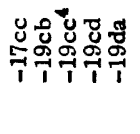 & 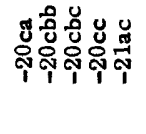 & 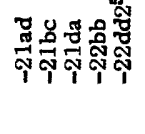 & 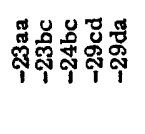 & 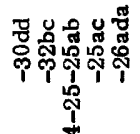 & 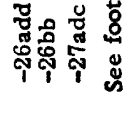 \\
\hline
\end{tabular}



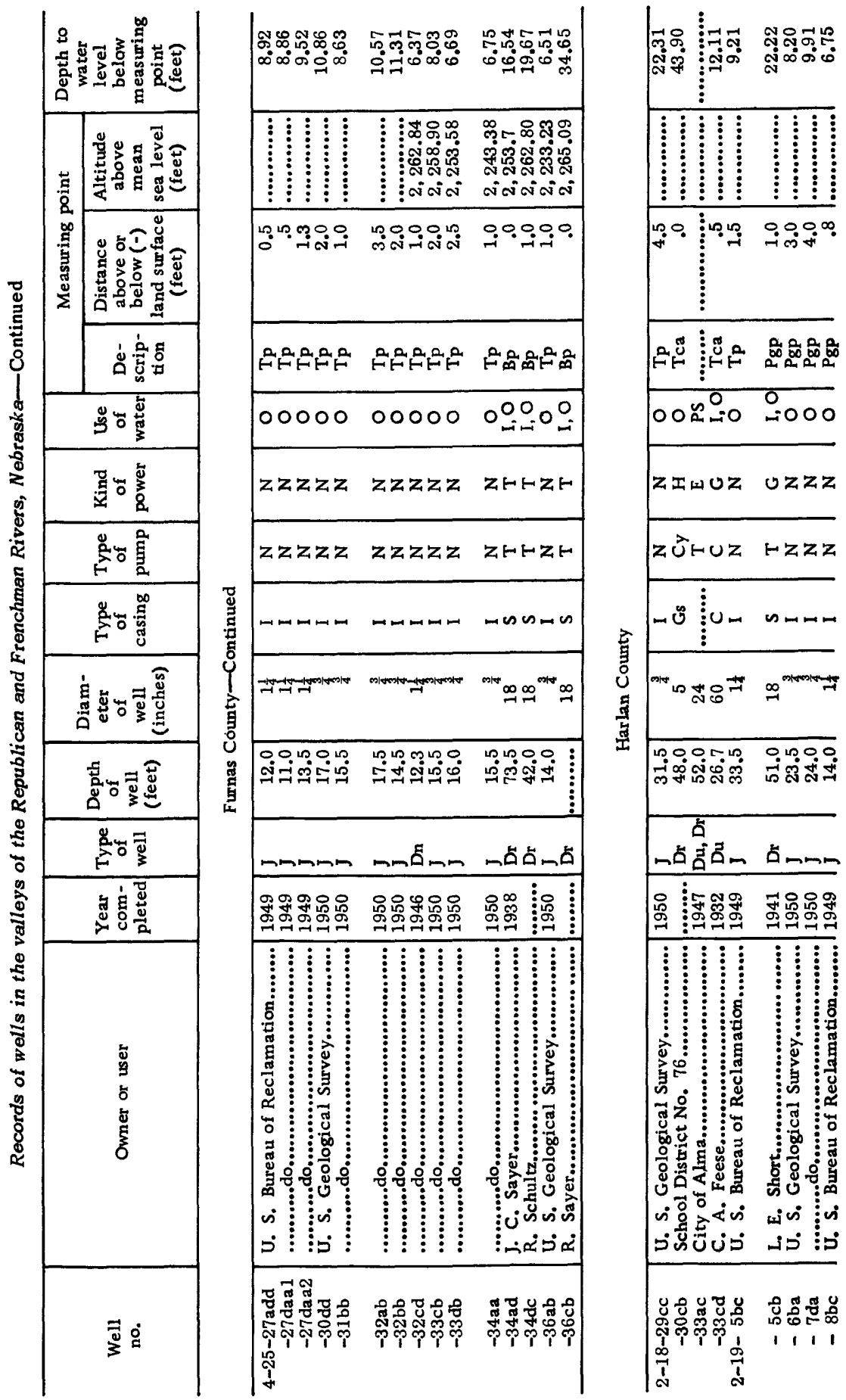
GROUND-WATER GEOLOGY, REPUBLICAN AND FRENCHMAN VALLEYS, NEBR. 703

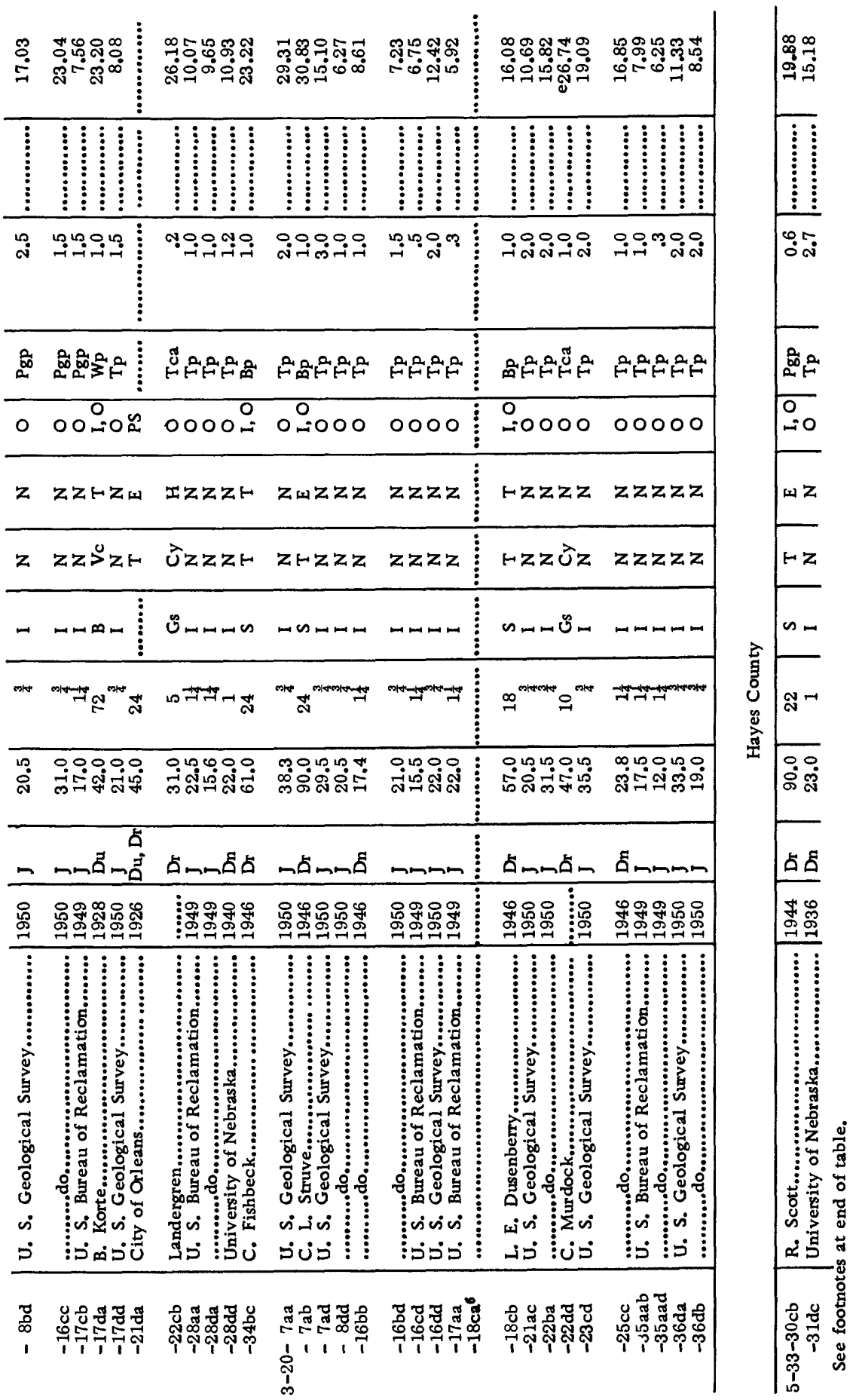




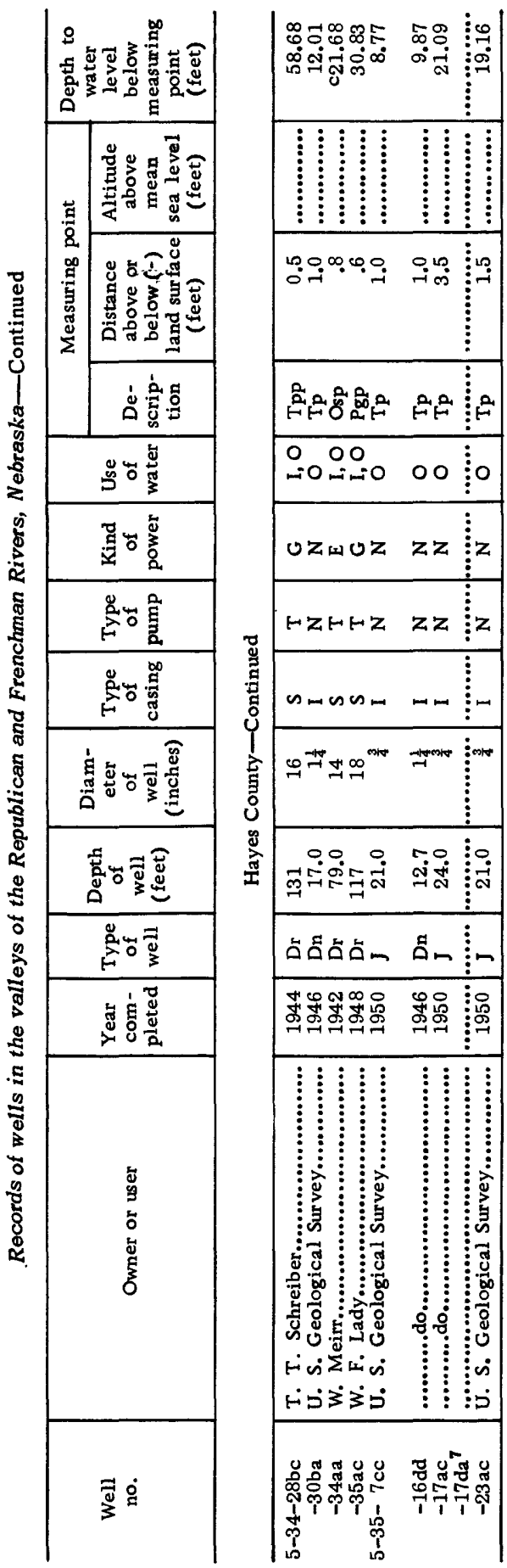

\begin{tabular}{|c|c|c|}
\hline 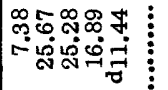 & 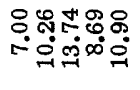 & 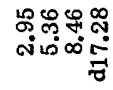 \\
\hline & 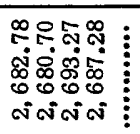 & 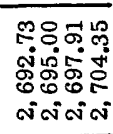 \\
\hline קִ & 육욤유 & تج \\
\hline 吕 & 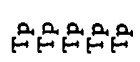 & 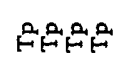 \\
\hline $00=0$ - & 00000 & 0000 \\
\hline Z国州 & $z z z z z$ & $z z z z$ \\
\hline$H H$ & $z z z z z$ & $z z z z$ \\
\hline & & ルேルே \\
\hline 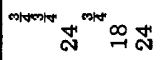 & 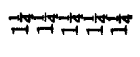 & 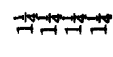 \\
\hline 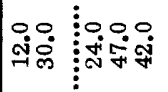 & 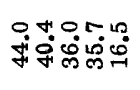 & 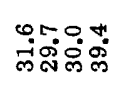 \\
\hline ローロ̆ロロ & クローロヒ์ & றோை \\
\hline 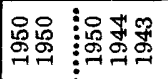 & 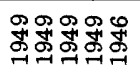 & 염엄웜웜 \\
\hline 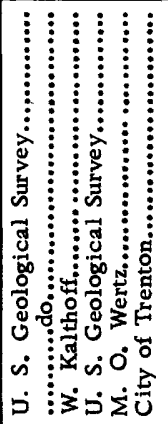 & 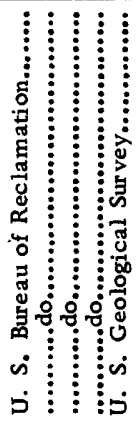 & 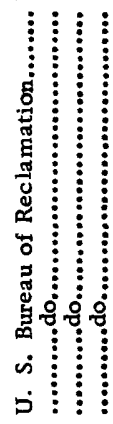 \\
\hline 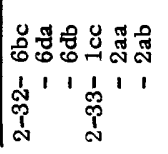 & 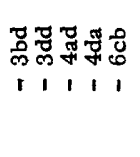 & 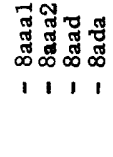 \\
\hline
\end{tabular}


GROUND-WATER GEOLOGY, REPUBLICAN AND FRENCHMAN VALLEYS, NEBR. 705

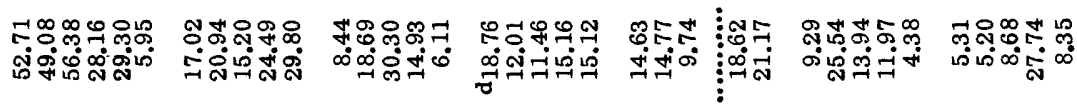

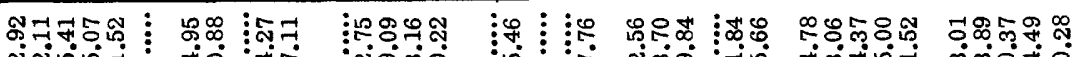

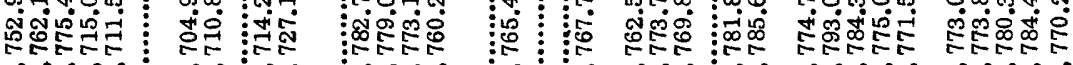

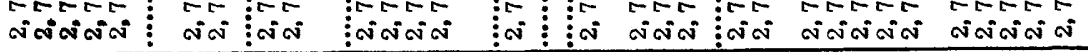

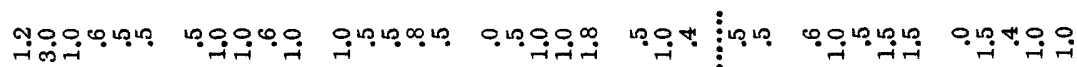

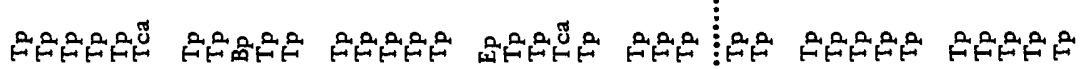
OOOOOO OO

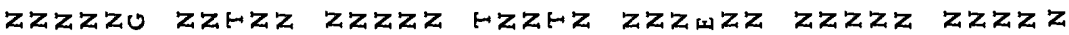

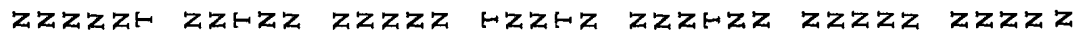

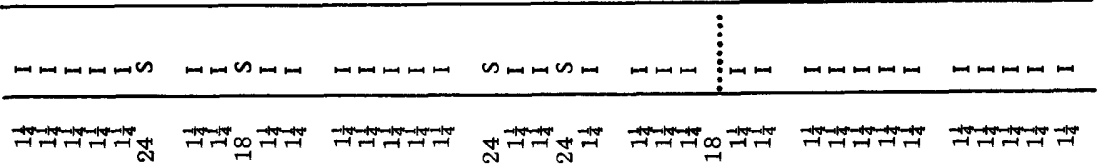

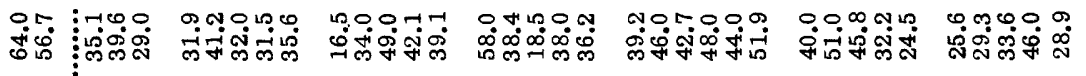

\begin{tabular}{|c|c|c|c|c|c|c|}
\hline ロேロロロ & ローロ̆ゥー & ロีロルロル & ロேロロ์ロேロ & ேーーロ゙ロー & mறேmm & ロロロロロ \\
\hline 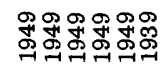 & 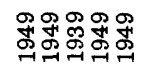 & 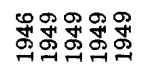 & 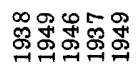 & 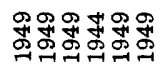 & 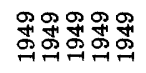 & 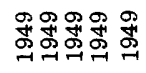 \\
\hline 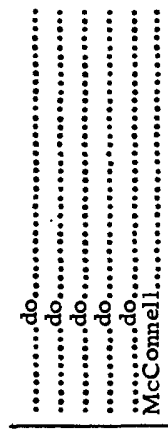 & 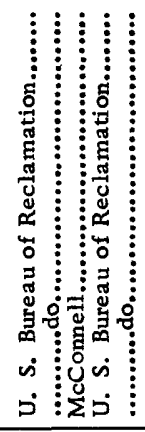 & $\begin{array}{c}\vdots \\
\vdots \\
\vdots \\
\vdots \\
\vdots \\
\vdots\end{array}$ & 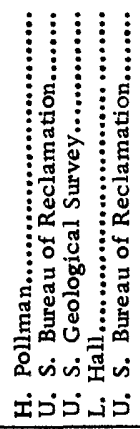 & 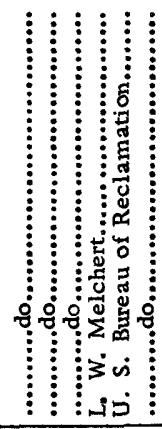 & 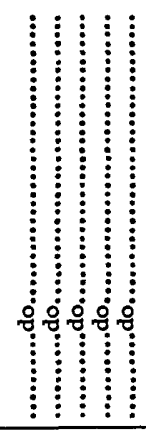 & 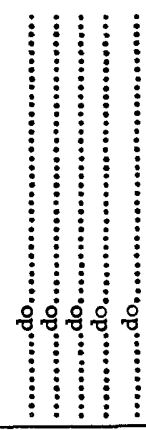 \\
\hline 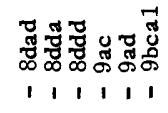 & 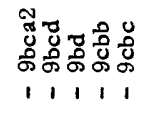 & 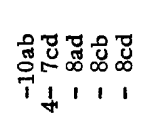 & 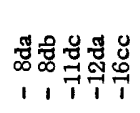 & 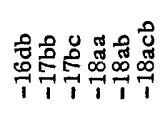 & 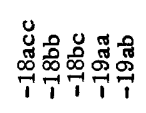 & 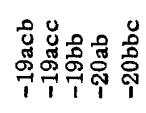 \\
\hline
\end{tabular}




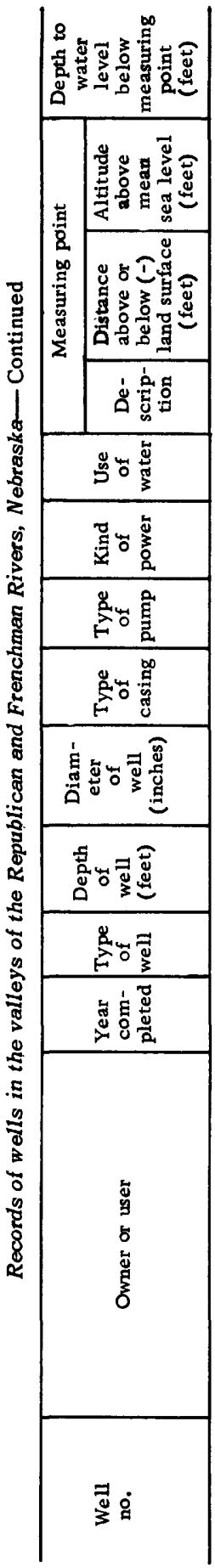

\begin{tabular}{|c|c|c|c|c|c|}
\hline 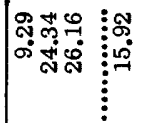 & 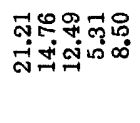 & 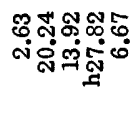 & 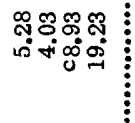 & 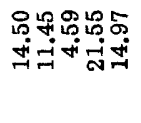 & $0^{\circ}$ \\
\hline 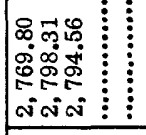 & 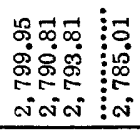 & 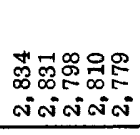 & 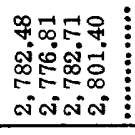 & $\begin{array}{c:c:}\vdots & \vdots \\
\vdots & \vdots \\
\vdots & \vdots \\
\vdots & \vdots \\
\vdots & \vdots \\
\vdots & \vdots \\
\vdots & \vdots \\
\vdots\end{array}$ & \\
\hline & 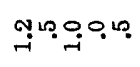 & 200 & & 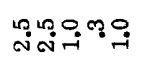 & \\
\hline : & 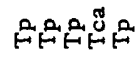 & 总吕兽 & & 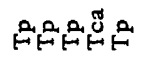 & \\
\hline 0 & 00000 & $\begin{array}{lc}0 \\
-00 \text { vio }\end{array}$ & 0000 & 00 & 0 \\
\hline z & $z z$ & Uzz & $z z$ & $z z$ & 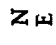 \\
\hline zz & $z z$ & Hトzờz & $z$ & $z z$ & $z$ \\
\hline 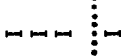 & - & $\sin 0$ & & & \\
\hline 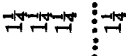 & नrth & 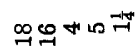 & 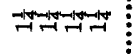 & masto & \\
\hline 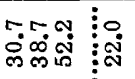 & 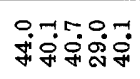 & 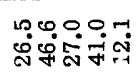 & 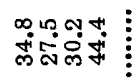 & 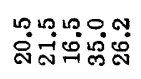 & ตัต \\
\hline ñ & ロேーロ̆ロ & 占占占占 & & 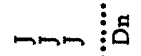 & ー日̆ \\
\hline 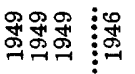 & 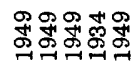 & ஜூ్ర & 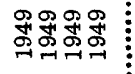 & 茵号号 & 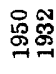 \\
\hline 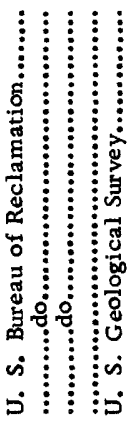 & 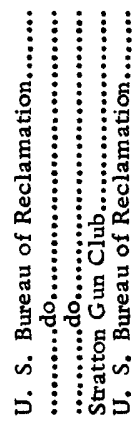 & $\begin{array}{c} \\
\vdots \\
\vdots \\
\vdots\end{array}$ & 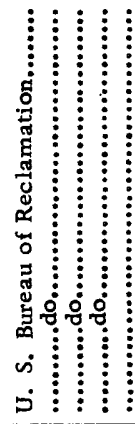 & 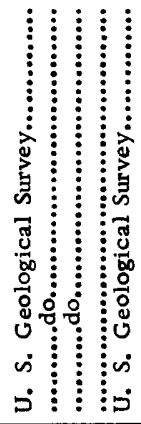 & $\begin{array}{c}0 \vdots \\
\vdots \\
\vdots \\
\vdots\end{array}$ \\
\hline 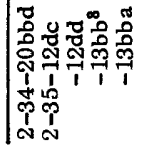 & 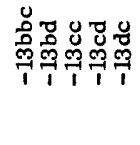 & 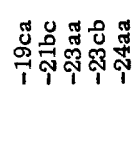 & 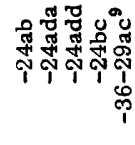 & 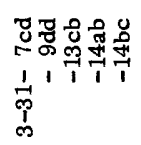 & 记 \\
\hline
\end{tabular}


GROUND-WATER GEOLOGY, REPUBLICAN AND FRENCHMAN VALLEYS, NEBR. 707

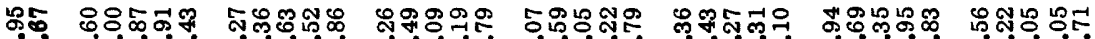

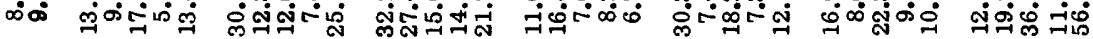

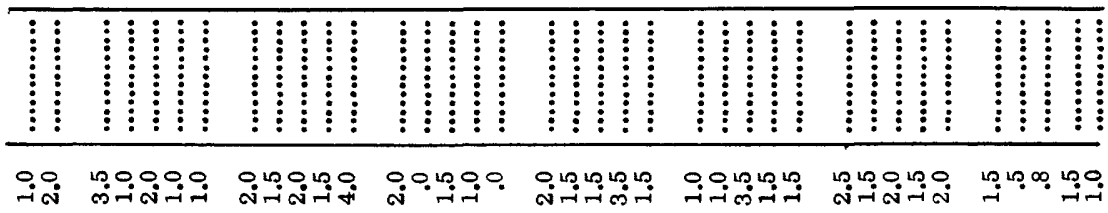

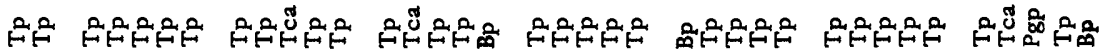

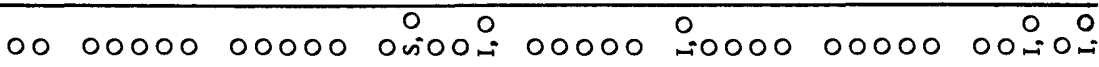

zz zzzzz zzzzz zзzzu zzzzz fzzzz zzzzz zzw

zz zzzzz zzzzz zừzt zzzzz Hzzzz zzzzz zzHzt

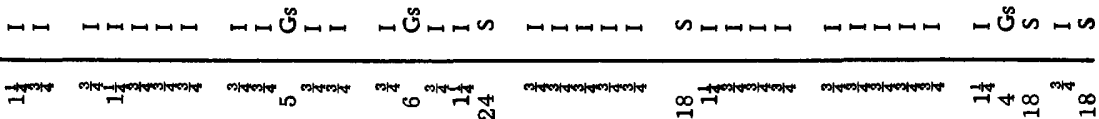

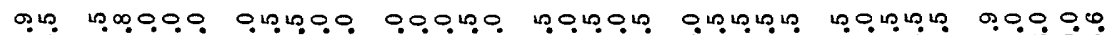

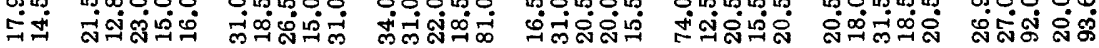

\begin{tabular}{|c|c|c|c|c|c|c|c|}
\hline 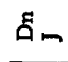 & ロロேロロー & ローロ̆ロா & 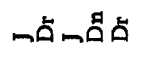 & ロோロ & 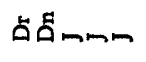 & ハோロー & ถ์ดัดロ \\
\hline 영유 & 员象品品员 & 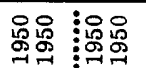 & 吕: & 品品品品号 & 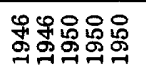 & 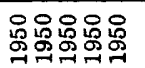 & \\
\hline
\end{tabular}

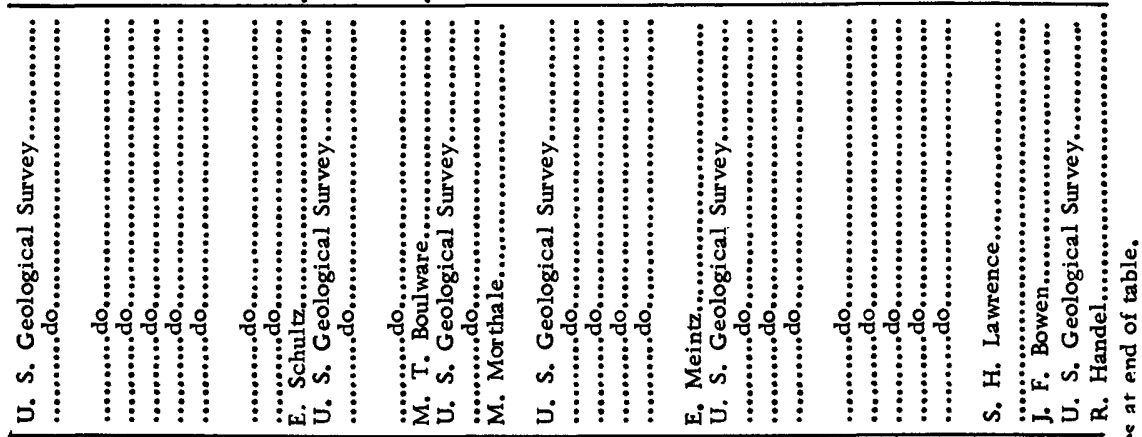

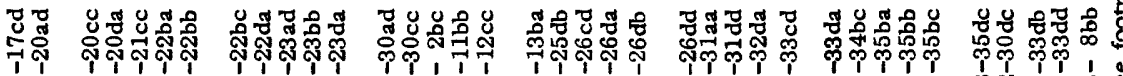

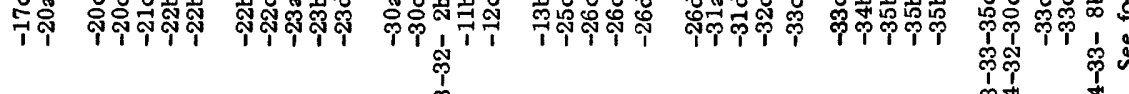
का क्ष 

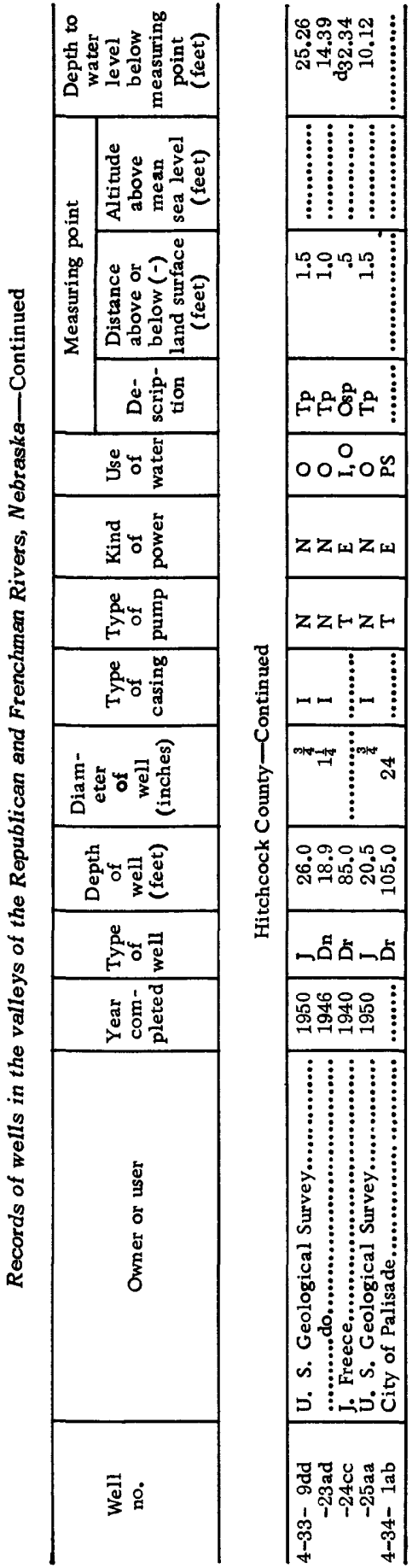

|

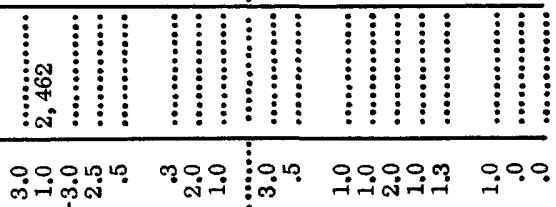

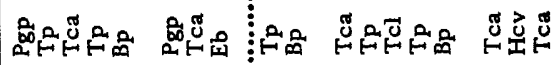

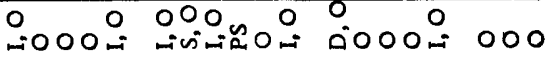

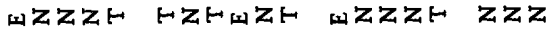

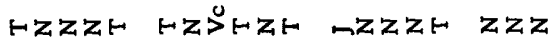

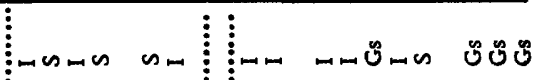
3
8
3
3
3
3
0

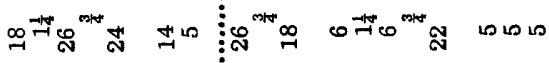

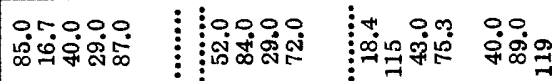

\begin{tabular}{|c|c|c|c|}
\hline מี & مّ & ดี ดี & \\
\hline 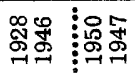 & 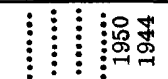 & 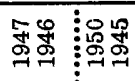 & \\
\hline 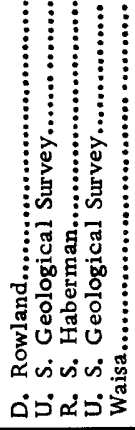 & 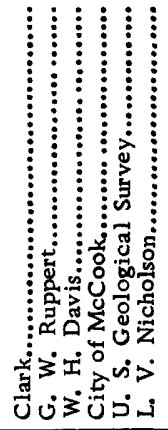 & 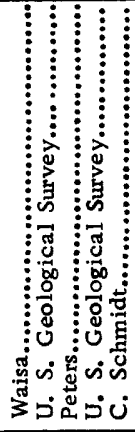 & $\begin{array}{r}\vdots \\
\vdots \\
\vdots \\
\vdots \\
\vdots \\
\vdots \\
\vdots \\
\vdots \\
\vdots \\
\vdots \\
\vdots\end{array}$ \\
\hline 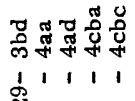 & 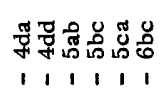 & 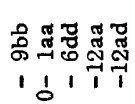 & 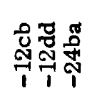 \\
\hline
\end{tabular}




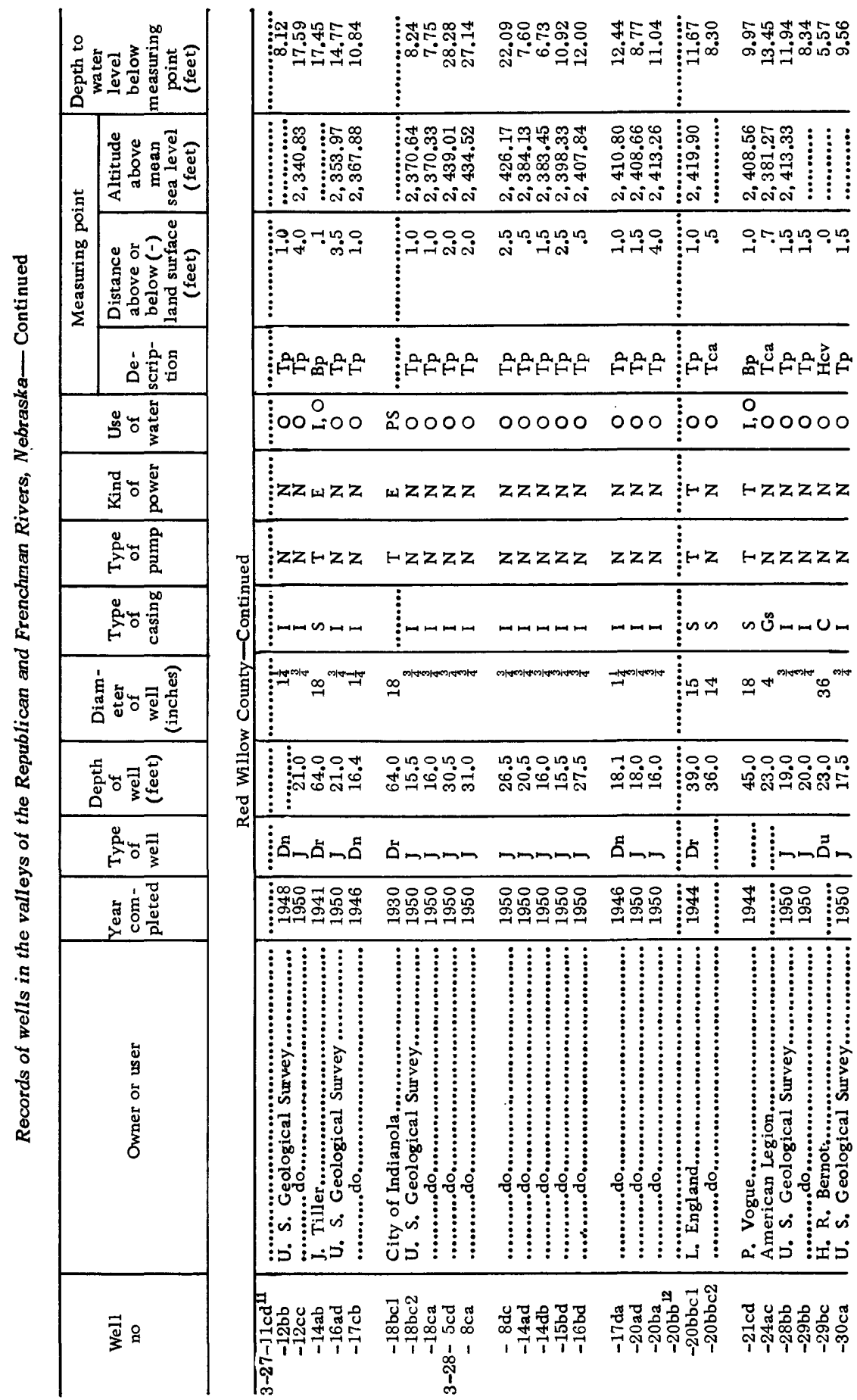




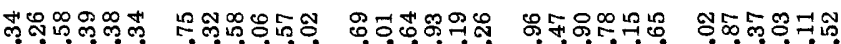

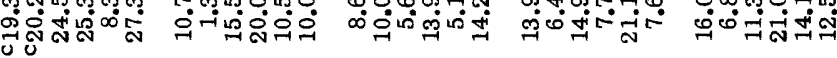

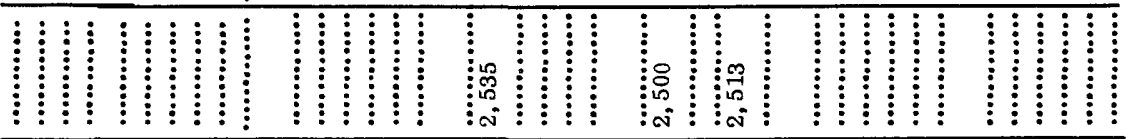

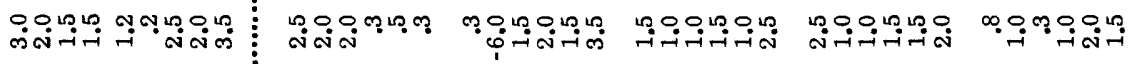

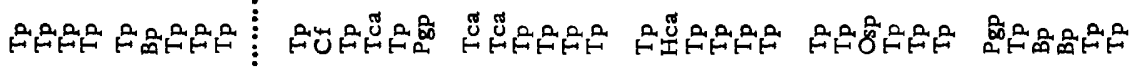

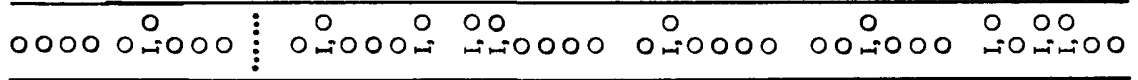

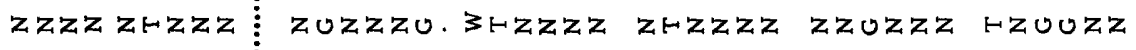

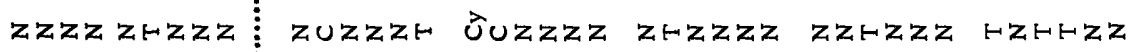

\begin{tabular}{|c|c|c|c|c|c|}
\hline ロロッロロのッロロ & ロேッర்ロル & 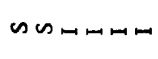 & Mルேルール & ロேのッロロ & 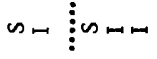 \\
\hline 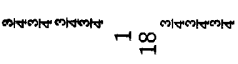 & $\mathrm{N}^{m / 4}$ & 에 & 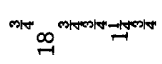 & 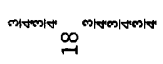 & $\mathbb{I}^{\infty+\infty} \stackrel{ \pm N}{\mathbb{N}}$ \\
\hline
\end{tabular}

n

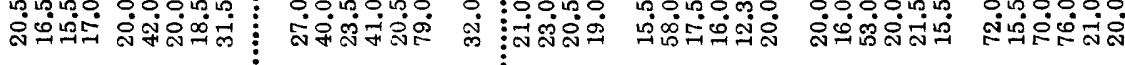

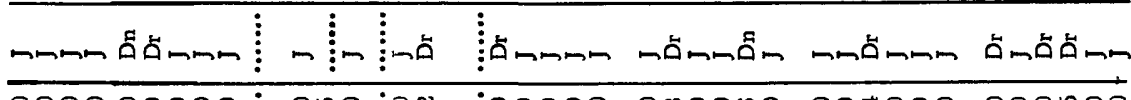

\begin{tabular}{|c|c|c|c|c|c|}
\hline م & 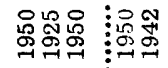 & :ం & 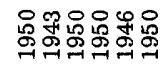 & హె & \\
\hline 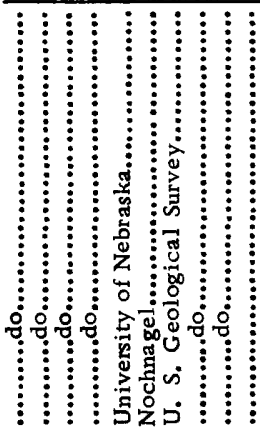 & 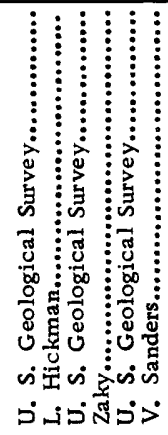 & 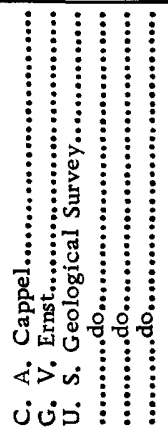 & 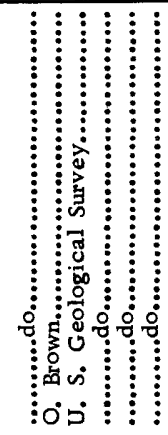 & 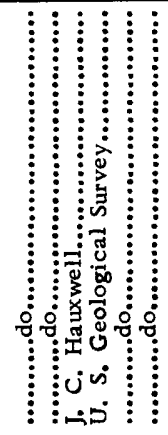 & 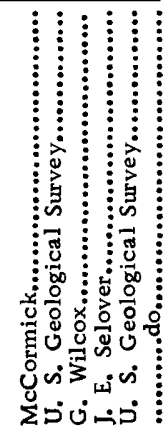 \\
\hline
\end{tabular}

ㅁํㅇํㅇ 요

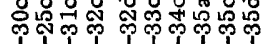

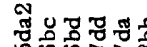

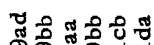

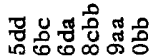

फ़ण

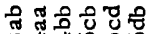

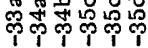

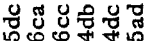
i 


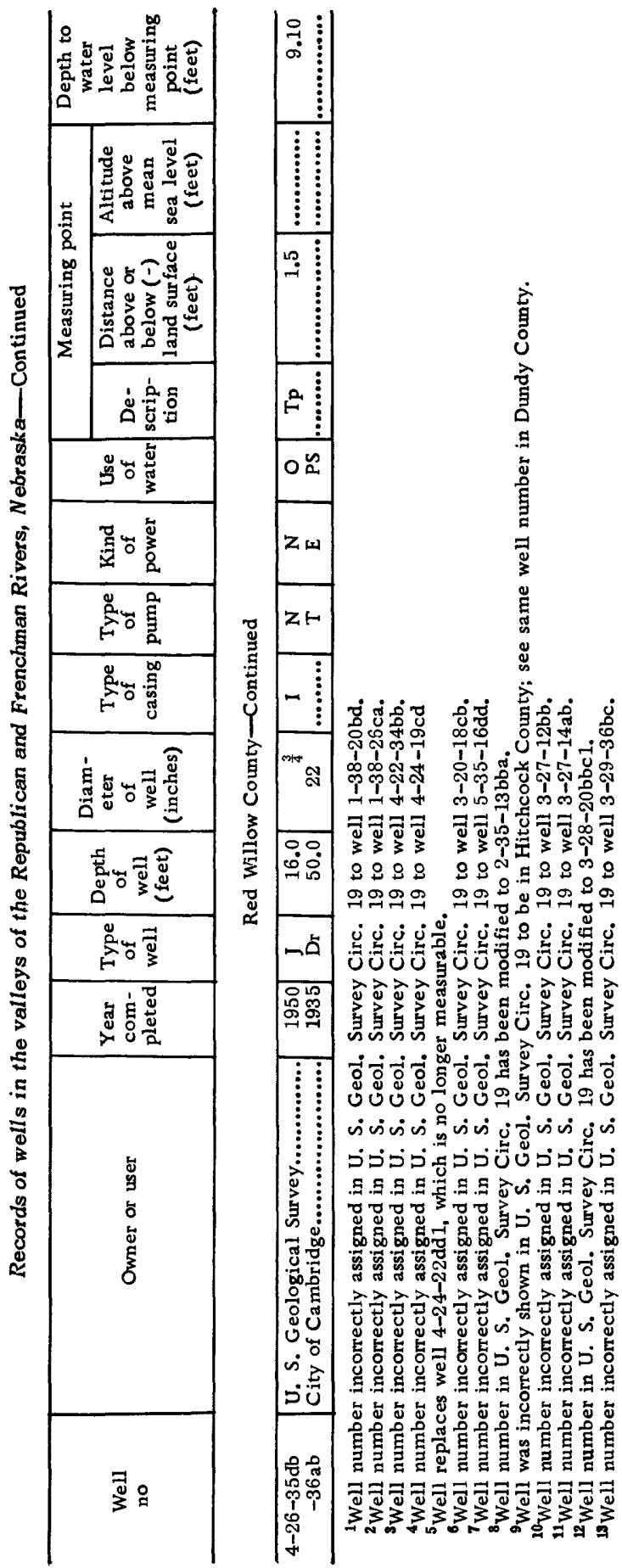




\section{INDEX}

Acknowledgments........................... 595

Agriculture .................................... 598

Alluvium........................600, 610-611

Analyses................................ 622-623

Bibliography ................................. 629

Bignell loess..........................600, 610

Carlile shale.............................601, 602

Chemical analyses....................622-623

Chemical quality of ground water...622-628

Citellus zone..................................608

Climate...................................596-598

Cretaceous rocks.......................599-604

Crete formation, lithology......600, 607-608 water supply................................600

Depth to water.

618-619

Discharge of ground water, evapotranspiration........615, 617, 620 ,

seepage into streams................615, 617 springs and seeps...........................615 underflow out of the area................616 wells............................616, 617, 620

Domestic water supplies, quality.....624-625 source..................................611, 616

Drainage...............................595-596

Enders Reservoir....................... 620-621

Extent of area............................. 590

Fluctuations of water table............619-623

Fort Hays limestone member.............. 602

\section{Geologic formations, generalized} section............................600-601

Grand Island formation...............600, 606 Gravel of late Wisconsin age........600, 610

Holdrege formation...................600, 606

Investigations, present..................... 593 previous.............................590, 593

Irrigation water, quality................625-628 sources of supply...................598, 616

Lake Creek member......................... 604

Literature cited...............................6 629

Location of area............................... 590

Loveland formation, lithology............600, 608-609 water supply 600,609

Loveland soil

$620-622$

Medicine Creek Reservoir

Movement of ground water....616, 617, 620

Municipal water supplies, quality....624-625 source.
Niobrara formation, lithology....599, 601, 602 water supply.....................601, 602-603

Occurrence of ground water................... 612 Ogallala formation, lithology.....601, 605-606 water supply..............................601, 606

Pearlette ash member..........................607 Peorian loess, lithology.........................60 609-610 water supply...........................600, 610

Pierre shale, lithology.............601, 603-604 water supply...........................601, 604

Precipitation......................596, 597, 598

Recharge of ground water, irrigation seepage....................................... 618 precipitation................612-613,620, 623 Republican River................613, 617, 623 reservoir seepage....................... 620-622 snowmelt....................................... 612 underflow from upland................613, 615

Salinity hazard......................6618, 625-628

Salt Grass member..............................6 604

Sand of late Wisconsin age..............600, 610

Sappa formation......................600, 606-607

Sharon Springs member............................ 604

Smoky Hill chalk member.................... 602

Sodium hazard............................. 625-628

Soil salimity......................618, 625-628

Temperature.......................596, 597, 598

Tertiary rocks..............................605-606

Topography.............................. 595-596

Water-level measurements, Chase

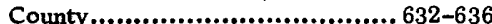

Dundy County.............................636-642

Frontier County......................... 642-643

Furnas County............................ 643-658

Harlan County............................658-662

Hayes County............................663-664

Hitchcock County..........................664-679

Red Willow County...................... 679-694

Water table, configuration of............. 617-618

depth to.....................................618-619

fluctuations of...........................619-623

Well-numbering system....................593-594

Well records, Chase County..............696-697

Dundy County..............................697-698

Frontier County...............................698

Furnas County.............................699-702

Harlan County...........................702-703

Hayes County..............................703-704

Hitchcock County ...................... 704-708

Red Willow County.......................708-712

Weskan member.................................. 604 

1 
